


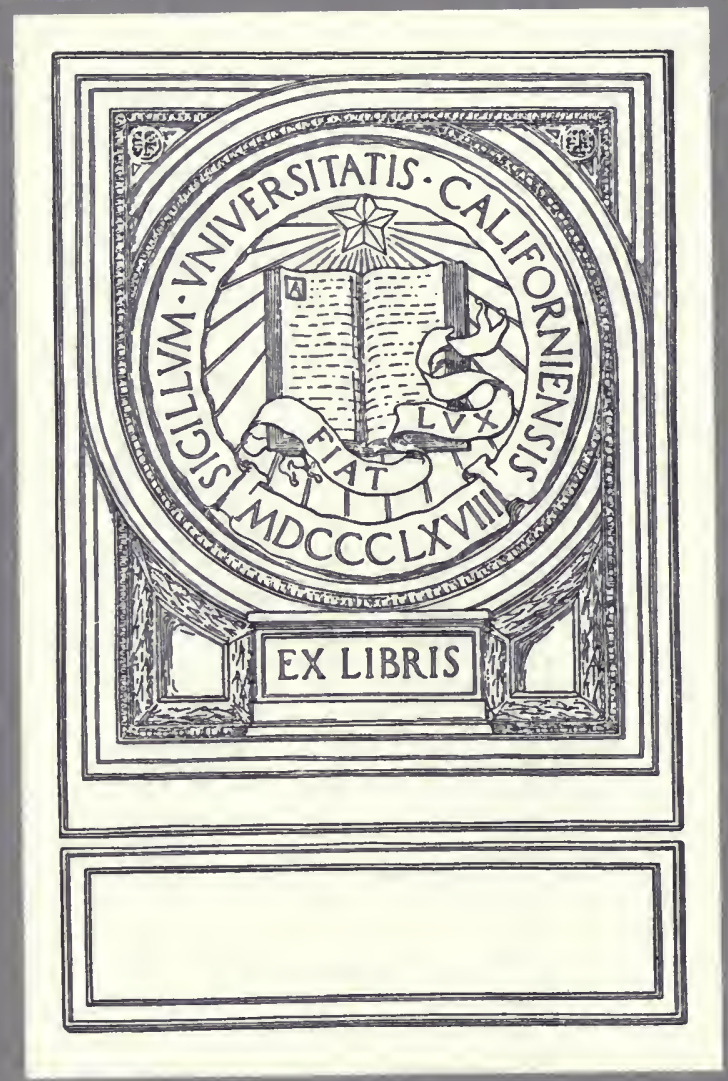


$-$

$+=$

4

18.
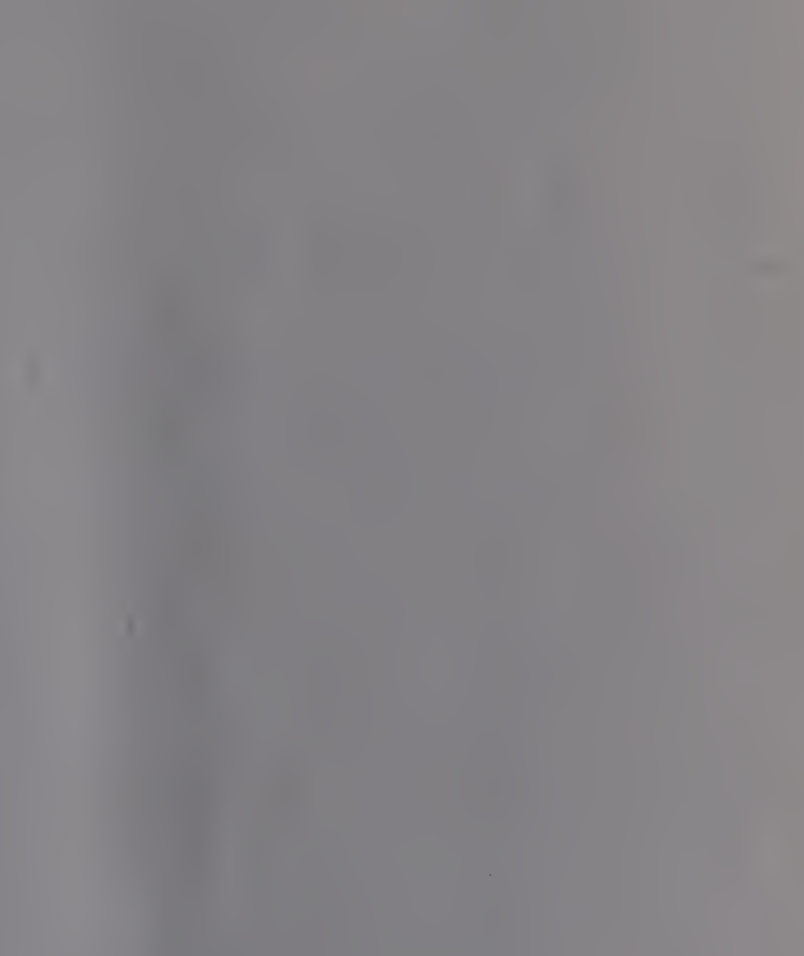

\section{*}

a

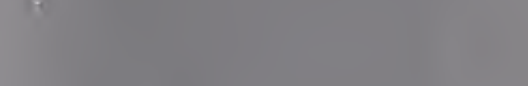

Ple
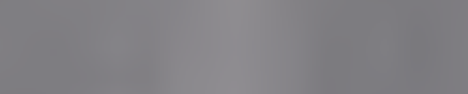
: 
Digitized by the Internet Archive in 2007 with funding from Microsoft Corporation 

Library of tharvard University.

\title{
BIBLIOGRAPHICAL CONTRIBUTIONS.
}

\author{
EDITED BY JUSTIN WINSOR,
} LIBRARIAN.

\section{No. 51. Ulast no of is.}

ত̂l Bartlett Collection.

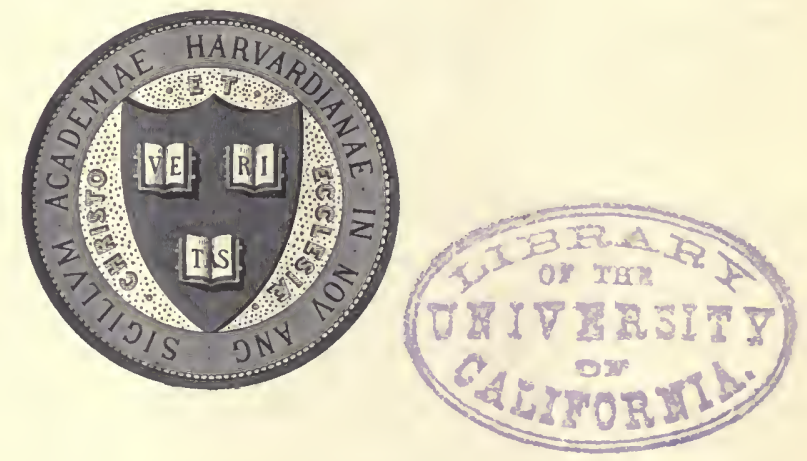

A LIST OF BOOKS ON

ANGLING, FISHES, AND FISH CULTURE,

IN

HARVARD COLLEGE LIBRARY.

By LOUISE RANKIN ALBEE.

CAMBRIDGE, MASS. :

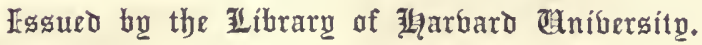

I 896. 


\section{Already issued or in preparation:}

[Some of these Contributions are out of print.]

\section{VOL. I.}

1. EDWARD HOLDEN. Index.Catalogue of Books and Memoirs un the Transits of Mercury.

3. JUSTIN Winsor. Shakespeare's Poems : a Bibliography of the Earlier Editions.

3. Charles Eliot Norton. Principal books relating to the Life and Works of Michelangelo, with Notes.

4. Justrn Winsor. Pietas et Gratulatio. An Inquiry into the authorship of the several pieces.

5. List of Apparatus in different Laboratories of the United States, available for Scientific Researches involving Accurate Measurements.

6. The Collection of Books and Autographs, bequeathed to Harvard College Library, by the Honor. able Charles Sumner.

7. Wrlliam C. LaNe. The Dante Collections in the Harvard College and Boston Public Libraries. Pt. I.

8. Calendar of the Arthur Lee Manuscripts in IIarvard College Library.

9. George Lincoln Goodaln. The Floras of different countries.

10. Justin Winsor. Halliwelliana: a Bibliography of the Publications of James Orchard Halliwell-Phillipps.
11. Samuel H. Scudder. The Entomological Librariee of the United States.

12. Fikst List of the Publications of Harvard University and its Officers. $1870-1850$.

13. Samuel H. Scudder. A Bibliography of Fossil Insects.

14. Wrlliam H. Trluinghast. Notes on the Historical Hydrography of the Handkerchief Shoal in the Bahamas.

15. J. D. Whitney. List of American A uthors in Geology and Palaontology.

16. Richard BLiss. Classified Index to the Maps in Petermann's Geographische Mittheilungen. 18551881 .

17. RICHARD BLIss. Classified Index to the Maps in the Royal Geographical Society's Publications. 1830$18 S_{3}$.

18. Justin Winsor. The Bibliography of Ptolemy's Geography.

19. Justin Winsok. The Kohl Collection of Early Maps.

20. William C. Lane. Index to Recent Reference Lists, no. I. 1884-1885.

\section{VOL. II.}

21. Second List of the Publications of Harvard University and its Officers. ${ }^{2} S 80-1885$.

22. JUStin Winsor. Calendar of the Sparks Manuscripts in Harvard College Library.

23. William H. Tillinghast. 'Third List of the Publications of Harvard University and its Officers. $1885-$ I886.

24. William C. Lane. Index to Recent Reference I.ists, no. 2. $1885^{-1} 886$.

25. W. G. Farlow and Willitam Trelease. List of Works on North American Fungi.

26. William C. Lane. The Carlyle Collection.

27. ANDrew McF. Davis. A few notes on the Records of Harvard College.

28. Wrlliam H. Tillinghast. Fourth List of Publications of Harvard University and its Officers. ${ }_{1} S 86-$ 1857 .
29. William C. Lane. Index to Recent Reference Lists, no. 3. 1887 .

30. Facsimile of the autograph of Shelley's poem "To a Skylark," with notes.

31. W. G. FARLow. Supplemental List of Works on North American Fungi.

32. H. C. BADGER. Matheinatical Theses, i78z-1839.

33. William H. Tillinghast. Fifth list of Publications

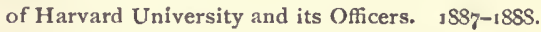

34. Wrlliam C. Lane. The Dante Collections in the Harvard College and Boston Public Libraries.

35. George E. Woodberry. Notes on the ms. of Shelley in the Harvard College Library.

36. Wyllyam C. Lane. The Treat Collection on Ritu. alism and Doctrinal Theology.

37. Frank Wettenkampf. Bibliography of Hogarth.

\section{VOL. III.}

38. Wrlliam H. Tillinghast. Sixth List of Publications of Harvard University and its Officers. 1885-1889.

39. Alfred C. Potter. Bibliography of Beaumont and Fletcher.

40. William C. Lane. Index to Recent Reference Iists, no. 4. 1890 .

41. William H. Trlinghast. Seventh List of Publications of Harvard University and its Officers. ISS91890 .

42. William H. Tillinghast. The Orators and Poets of Phi Beta Kappa, Alpha of Massachusetts.

43. Charles Gross. A Classified I.ist of Books relating to British Municipal History.

44. William H. Trllinghast, Eighth List of Publications of Harvard University and its Officers. 1890-1891.
45. Wrlliam C. Lane and Charles K. Bolton. Notes on Special Collections in American libraries.

46. THe Class of 1828, with a list of the publications of its members.

47. William H. Tillinghast. Ninth list of Publications of Harvard University and its Officers. 1891-1892.

48. Stephen B. Weeks. A Bibliography of the Historical Literature of North Carolina.

49. M. H. Morgan. A Bibliography of Persius.

50. ANDrew McF. Davis. An Analysis of the Early Records of Harvard College, $1636-1750$.

51. Louise R. Albee. Bartlett Collection of Books on Angling, Fishes and Fish Culture. 


\section{INTRODUCTORY NOTE.}

This collection was formed by John Bartlett, A.M. (Harv. I87I), of Cambridge, author of "Familiar Quotations," and a Concordance of Shakespeare, etc., himself "a practitioner of more than fifty years, experience of the art of angling"; by him it was presented to the Library of Harvard College, Nov. I 7 th, I 892, when it numbered 1014 volumes and 269 pamphlets. A large proportion of the volumes are handsomely bound, the panels of the back being ornamented in many cases with dies showing fishes in gold.

After the collection was received, it was arranged in subject groups according to the scheme given on the next page, and to it were added most of what few books on angling proper the Library already possessed. In other groups of the collection, however, the like was not done, and the catalogue, therefore, does not represent the full strength of the College Library in fisheries, fish culture, the natural history of fishes, etc.; nor have there been added from the College Library any books dealing indirectly with angling, like travels and other descriptive works, which Mr. Bartlett collected in large numbers.

The books were catalogued and the list prepared by Miss Louise Rankin Albee, of the Library staff, in the summer and autumn of I 893, and the spring of 1895 , pressure of other work necessitating long interruptions.

The arrangement of titles and the position of shelf-marks on the printed page have been determined solely by the requirements of the card catalogue, since the list is printed from the type set up for the cards.

A catalogue of the collection was printed at Gambridge in 1882 [Ang. 1.55], and a supplement in 1886. [Ang. 1.56]. A second supplement exists in manuscript [Ang. 1.56]. 


\section{OUTLINE OF THE SHELF CLASSIFICATION.}

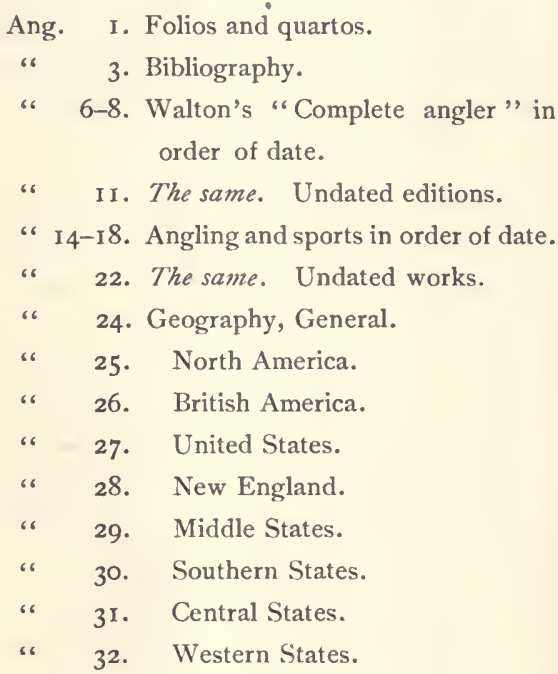

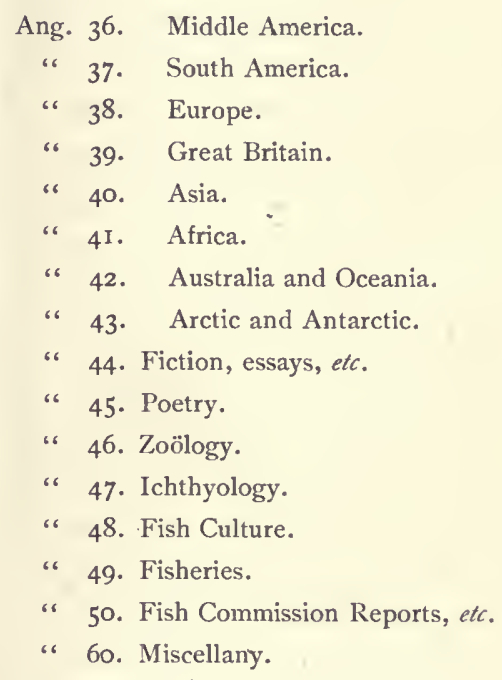




\section{THE BARTLETT COLLECTION}

OF BOOKS ON

\section{ANGLING, FISHES, AND FISH CULTURE.}

Ang. 39.46 Abbott, Samuel, sportsman. Ardenmohr among the hills; a record of scenery and sports in the Highlands of Scotland. With illustrations sketched, etched, etc. by the author. London. $1876.8^{\circ}$. Front. and plates.

Contains several chapters on fishing.

*Ang. 16.75.9 Accomplish'd lady's delight, (The), in preserving, physick, beautifying, cookery, and gardening. 9th ed., inlarged. London. $1706.24^{\circ}$. Illustr. title-page and zudcts.

Attributed to Mrs. Hannah Wolley.

This edition does not contain the part on angling. For a later edition, containing this part, see Compleat servant-maid (The).

Account (An) of the new method of fishing on the coasts of Shetland. I884. $8^{\circ}$. See [Fea, James].

Ang. 48.II Ackerhof, A. D. Die nutzung der teiche und gewässer durch fischzucht und pflanzenbau. Quedlinburg. 1869. sm. 8. Plan.

"Literatur," after p. 140.

Ang. 26.2 Adams, Andrew Leith. Field and forest rambles, with notes and observations on the natural history of eastern Canada. London. I873. $8^{\circ}$. Front., maps, wdcts., etc.

"Fishes," pp. 199-257.

I0 $\frac{1}{2} .23$ Another copy.

Ang. 49.46 Adams, Walter Marsham. A popular history of fisheries and fishermen of all countries, from the earliest times. London. I883. 8․ pp. (2), 84. (LONDON, Eng.International fisheries exhibition, I883. [The fisheries exhibition literature, i. 6.])

Also another edition.

*Ang. 26.6 [Adamson, William Agar.] Salmon-fishing in Canada ; by a resident. Edited by Sir J. E. Alexander. London, etc. 1860. sm. $8^{\circ}$. Front., map, plate, wdcts., and plan.

The appendix includes "Observations on the habits of the salmon family; by W. Henry." 
Ang. 49.46.5 Adderley, Sir Augustus John. The fisheries of the Bahamas. [With "Report upon the sponges of the Bahama islands, by W. S. Kent."] London. I $883.8^{\circ}$. pp. 58. (LoNDON, Eng.-International fisheries exhibition, 1883. [The fisheries exhibition literature, v. I I.])

Also another edition.

Adventures (The) of a salmon in the river Dee. I 853. I 6. See [Ayrton, William].

Ang. 46.5 झlianus, Claudius. De natura animalium libri xvii. Graece et latine cum priorum interpretum et suis animadversionibus edidit J. G. Schncider. Lipsiae. I $784 . \quad 8^{\circ}$. pp. x., 585, (20), 228, (44).

The first chapter of the fifteenth book contains the first account by any author of fishing with the artificial fly. A translation of the passage is found in Osmund Lambert's “ Angling literature in England," pp. I2-14. Ælian's work also includes particulars of other modes of fishing by the ancients. The author lived at Rome about the middle of the third century.

Ga 3.370 Another copy.

47.3 Agassiz, Louis. Contributions to the natural history of the United States of America. 5 vol. Boston, etc. I85777. $4^{\circ}$. Plates and wdcts.

Contents:-i. Essay on classification. North American testudinata. 1857. - ii. Embryology of the turtle. I857.- iii. Acalephs in general. Ctenophoræ. 1860. - iv. Discophoræ. Hydroidæ. Homologies of the radiata. 1862.- v. Embryology of the starfish. Hard parts of some North American starfishes. By Alexander Agassiz. $\quad$ I877.

Four of the plates are colored.

Vol. v. has also the title, " North American starfishes, by Alexander Agassiz, Cambridge, 1877." The first part together with plates i.-viii. was first published in Dec. 1864. "The cyprinodonts" by S. Garman is to be regarded as a continuation of this work.

47.3I Another copy of vol. i.-iv.

Ang. I.I9 Another copy of vol. i., ii., iv.

Ang. I.I9.2 Another copy of vol. iv.

*Ang. I.3I Agassiz, Louis. Histoire naturelle des poissons d'eau dotice de l'Europe centrale. [Tom. i.] Neuchâtel. I842. 1. $8^{\circ}$, and atlas of $4 \mathrm{I}$ plates, livr. I, 2 (in I vol.), $\mathrm{I} 389$ [i 839$]-42$, obl. $4^{\circ}$.

No more published.

Contents:- [i.] Embryologie des salmones; par C. Vogt.

Of the plates, 23 are colored. The descriptions are in French, German, and English.

46.51 Another copy.

(Atlas, 46.26) The date of the 1st livraison of the atlas is correct in this copy. 
Ang. 46.4 Agassiz, Louis. Lake Superior; its physical character, vegetation, and animals, compared with those of other and similar regions. With a narrative of the tour by J. E. Cabot, and contributions by other scientific gentlemen. Boston. I $850.8^{\circ}$. Front., wign., map, and I 5 plates.

"Fishes of Lake Superior," pp. 246-377.

"The landscape illustrations are from sketches made on the spot by Mr. Cabot. Those of the second part were drawn and lithographed by Mr. Sonrel, a Swiss artist of much distinction in this branch." Five of the plates contain illustrations of fishes.

45.53 Another copy.

Ang. 18.50 Akerman, John Yonge. Spring-tide; or, The angler and his friends. London. i 850 . I $6^{\circ}$. Front., vign., and plates. "A series of fishing scenes, with illustrations of the West-country dialect," is added to the title of the copy quoted by Westwood and Satchell.

*Ang. 1.27 Albin, Eleazar. The history of esculent fish, with plates drawn and engraved by Eleazar Albin; and an essay on the breeding of fish, and the construction of fish-ponds, by Roger North. London. 1794. $4^{\circ}$. pp. 80. i 8 col. plates.

*Ang. 1.37 Aldam, W. H., editor. A quaint treatise on "Flees, and the art a artyfichall flee making"; by an old man well known on the Derbyshire streams as a first-class fly-fisher a century ago. Printed from an old MS. never before published, the original spelling and language being retained; with editorial notes, and patterns of flies, and samples of the materials for making each fly. London. I $876.4^{\circ}$. Col. front. and 7 plates.

The frontispiece and one of the plates are chromo-lithographic fac-similes from water drawings by James Poole; the other plates contain 22 samples of flies, and materials for making them.

Ang. I.8 Aldrovandi, Ulisse. De piscibus libri v., et de cetis lib. unus. J. C. Uterverius collegit, Hieronymus Tamburinus in lucem edidit. Bononiae. 1613. fo. pp. (8), 732, (27). Wdcts.

The title-page is engraved.

The date in the colophon is 16 I2.

"Not merely ichthyological. To many of the descriptions of fish is appended a chapter "Capiendi ratio." "-Westwood and Satchell.

Alexander, Sir James Edward, editor. Salmon-fishing in Canada. 1860. $8^{\circ}$. See [Adamson, W. A.].

Ang. 39.67 Alexander, William (1767-1816). Journey to Beresford hall, [the seat of Charles Cotton, Esqre. London. I 841.] $4^{\circ}$. pp. (2), ff. 7. Lithographed.

A fac-simile of his manuscript account, printed on one side of the leaf only.

This work is more often quoted as containing a preface, memoir of the author, and poem "Walton and Cotton in the fishing house." 
Ang. 49.46.4 Alfred Ernest Albert, Ist duke of Edinburgh, son of Victoria I. of Gr. Brit. Notes on the sea fisheries and fishing population of the United Kingdom; arising from information and experience gained during three years' command of the naval reserves. London. 1883. $8^{\circ}$. pp. 65. Map. (London, Eng.-International fisheries exhibition, 1883. [The fisheries exhibition literature, iv. 2.])

\section{Also another edition.}

Ang. 18.59.2 [Alfred, H. Jervis.] A complete guide to spinning and trolling. By Otter. New ed. London. [I 879.] sm. $8^{\circ}$. pp. viii., 84. Front., plates, and wdcts.

Ist edition, 1859 .

Ang. 18.64.5 [Alfred, H. Jervis.]. The modern angler; containing instructions in the art of fly-fishing, spinning, and bottomfishing, fully describing the tackle and other requisites. With an account of the best places for angling, including the Thames, Lea, \&c. By "Otter." London. [1 864.] sm. $8^{\circ}$. Front., plates, and wdcts.

Contains many illustrations of tackle.

Ang. 18.64.6 [Alfred, H. Jervis.] The modern angler; by "Otter." New ed. London. [1876.] I $6^{\circ}$. Front., plates, wdcts., and $m a p$.

*Ang. 18.64.7 [- ] The same. New ed. London. [188-?] sm. $8^{\circ}$. Front., plates, and wdcts.

This edition has been somewhat enlarged, and a chapter on sea-fishing added.

"Ang. 47.34 Alfred, H. Jervis. On the science of "pike fishing." A paper read before the Gresham angling society, Ioth Nov., i 88I. London. [188I ?] $8^{\circ}$. pp. (20). Wdcts.

*Ang. 28.2 Allerton, Reuben German. Brook trout fishing; an account of a trip of the Oquossoc angling association to northern Maine, in June, I869. New York. I 869. sm. $8^{\circ}$. pp. 59+. Front., port. of G. S. Page, plates, and wdcts.

Some of the illustrations are from sketches by the author.-G.S. Page was president of the association.

Ang. 18.62.8 Alquen, Franz Ludwig Hermann D'. Vollständiges handbuch der feinern angelkunst. Nach den besten quellen und eigenen erfahrungen bearbeitet. Leipzig. I 862. sm. $8^{\circ}$. Wdcts, and plate.

The plate contains representations of 33 different flies, with their English names.

Amateur angler's days in Dove Dale (An). I $884 . \quad$ I $6^{\circ}$. See [Marston, Edward]. 
Ang. 1.I7 American angler (The); a weekly journal of anglingbrook, river, lake, and sea - fish culture. W. C. Harris, editor. Vol. i.-xiii.; xiv. no. I-I8. Oct. I5, 1881Nov. 3, I 888. New York. 188 I-88. fo and $4^{\circ}$. Wdcts., portrs., maps, and plans.

Imperfert: - vol. vi. no. I, and title-pages of vol. iv., v., ix., xii., xiv., wanting.

American angler's guide (The). 1845, etc. Sec [Brown, J. J.].

Ang. 18.85.2 American fish and how to catch them; a hand-book for fishing. By an old angler. New York. I 885. $8^{\circ}$. pp. 95.

Ang. 49.47 American fish culturists' association. Proceedings of the association at its $3 \mathrm{~d}$ annual meeting, Feb. 10, 1874. Rochester, N. Y. $1874 . \quad 8^{\circ}$.

In 1884 the name of the association was changed to the "American fisheries society."

Ang. 49.47 American fisheries society. Transactions, 14th annual meeting, held in Washington, D. C., May 5 th and 6th, I 885. New York. I 885. $8^{\circ}$.

This society was established in 1871 , and called the "American fish culturists' association," afterwards, the "American fish cultural association."

*Ang. 47.7 American naturalist (The). [Extracts from vol. i.-viii., on fishes and other water animals. Salem, Mass. 186774.] $8^{\circ}$. Wdcts. and plates.

"The blind fishes of Mammoth cave and their allies, by F. W. Putnam," vi. 6-30.

Ang. 18.47 [Anderdon, John Lavicount.] The river Dove; with some quiet thoughts on the happy practice of angling. London. I 847 . I $6^{\circ}$. Wdct.

"To the reader" is signed " J. L. A."

An edition of 25 copies without date, or printer's name, was printed for private circulation in 1845 .

"Written in the orthorlox dialogue of fishing literature, it [contains] many anecdotes of Cotton and his country life, with hints on the best mode of following his favourite pursuit." - Dict. nat. biog.

Ang. 49.46. I I Andrews, T. The propagation of the salmonidx. Prize essay. London. I 884. 8\%. pp. 19. (London, Eng.-International fisheries exhibition, I883. [The fisheries exhibition literature, xi. 2.])

Also another edition.

*Ang. 18.34 Angler (The); containing a complete description of all iresh-water fish and the most approved methods of catching them; the best places for angling near London; with useful hints to anglers in general. [London. I 834?] sq. $24^{\circ}$. pp. I6. Wdcts.

There is no title-page. 
Angler in Ireland (The). I834. I $2^{\circ}$. See [Belton, - ].

Anglers (The); eight dialogues in verse. I773, etc. I $2^{\circ}$. See Art of angling (The).

Ang. 18.48.5 Angler's almanack (The). I 848. [Edited by J. Y. Akerman.] London. [1848.] Broadside. Wdct.

Ang. 18.49.2 Angler's almanac (The), for I 849; calculated for all parts of the United States. Containing besides the usual information, statistical accounts of fishing, anecdotes of angling, \&c. New York: Fohn F. Brown \& co. 1849. 8. Wdcts.

Ang. 18.53 Angler's almanac and pocket-book (The), for 1853I 855 . Being a hand-book and guide to the principal rivers, lakes, and fisheries in Great Britain, Ireland, and Scotland, and containing all the information required by the sportsman for the year. By a practical angler. 3 vol. London. [1 $852-54$.$] sm. 12^{\circ}$. Fronts., wdets., and port. of Isaac Walton.

No more published.

The frontispiece and two full page illustrations of fishes in the volume for 1855, are taken from Blakey's "Angling; or, How to angle and where to go." This volume also contains "The angler's library," pp. 74-79.

Ang. 22.3 Angler's assistant (The); or, A new and complete treatise on the art of angling. Containing every necessary instruction to practice with success this most healthy pastime; also directions for choosing and making angling rods, lines, flies, \&c. London. [I8I3?] sm. $8^{\circ}$. pp. 28. Front. and vign.

The frontispiece is dated 1813 .

Ang. 18.24 Angler's companion (The); being a complete practical guide to angling, with the properties, names, and where to be found of all river fish. To which is added Nobbs's Art of trolling, and the technical terms used in angling. London. [1824?] $12^{\circ}$. pp. 32. Col. front.

The frontispiece is dated 1824 .

The. "technical terms" do not appear.

Ang. 22.4 Angler's companion (The); being a description of where to find and how to fish the various swims in the Horse and Groom, Lea bridge, and White House fisheries. London. [18-.] I $6^{\circ}$. pp. 36. Front., wdcts., and map.

The angling treatise is followed by "An angling excursion; a true story."

Originally published in 1840,1841 , and 1843 as "The angler's guide to the Horse and Groom, Lea bridge, and White House fisheries." "The angler's companion and guide to the White House fishery," attributed by Pickering 10 James Martin, and published without date, is probably the forerunner of this work. 
Angler's desideratum (The). I 839. I $6^{\circ}$. See [Clarke, Capt.—, R. M.].

Angler's diary (The). [1878.] $8^{\circ}$. See [Cox, I. E. B.].

Anglers' evenings. I 880, etc. $8^{\circ}$. See Manchester, Eng. - Anglers' association.

Ang. 45.62 Angler's garland (The), and fisher's delight, for I 870, 1871. A right merrie wreath of rare old songs, secrets, \& suggestions in the art of angling. Embellished with a few "canny" woodcuts by Thomas Bewick. Selected and arranged by Edwin Pearson. 2 vol. Westminster, etc. I 870-7I. sm. $4^{\circ}$. Fronts. and wdcts.

"Only 350 copies."

No more published.

The first volume includes the "Angler's progress" by Herman Boaz, and a letter on salmon fishing by Thomas Bewick, dated 1824 . The second volume contains the "Fisher's garland" for $182 \mathrm{I}$, a reprint of the "Young angler's instructor" by Gervase Markham, etc. Many of the woodcuts were used on the "Newcastle fishers' garlands."

Angler's guide (The). I 828, 24 $4^{\circ}$. See [Gentleman angler (The)].

*Ang. 18.38.3 Angler's hand-book (The). Containing concise instructions for every department of the art. $3 \mathrm{~d}$ ed. London, etc. $1840.32^{\circ}$. pp. 67.2 col. plates.

Imperfect:- pp. 5-8 wanting. "

The plates are dated $188^{8}$, the date of the first edition.

Ang. 18.08 Angler's manual (The); or, Concise lessons of experience, which the proficient in the delightful recreation of angling will not despise, and the learner will find the advantage of practising. Containing useful instruction on every approved method of angling; with twelve plates, designed and etched by S. Howitt. Liverpool. I 808 . obl. $24^{\circ}$. pp. (4), iv., 28.

Half-title:- "Howitt's angler's manual."

Ang. 18.80.6 Angler's note-book and naturalist's record (The); a repertory of fact, inquiry, and discussion on field-sports and subjects of natural history. Green series complete. Jan. I -June 30, 1880 . s. $-m$. London. I $880.5 \mathrm{sm} .4^{\circ}$. Front. and plates.

Osmund Lambert in his "Angling literature in England" says of this publication, "There is only one periodical, in the ordinary sense of the word, which has for its main object all that relates to angling." 
Ang. 18.80.7 Angler's note-book \& naturalist's record (The); a repertory of fact, inquiry, \& discussion on the literature \& practice of field-sports \& on subjects of natural history. Conducted by the editors of the "Bibliotheca piscatoria." New series. No. I-5, 7-II. June 15, I 884-1886. [London.] I 884-86. $\mathrm{sm} .4^{\circ}$.

This series, published in 12 numbers, contains "A collector's hand-list of angling books; by Thomas Satchell."

*Ang. 18.05 Angler's pocket-book (The), or, Compleat English angler; containing all that is necessary to be known in that art. Also, Nobbs's celebrated treatise on the art of trolling. With an appendix, in which are improvements and discoveries never before published. $3 \mathrm{~d}$ ed. London. 1805. I $6^{\circ}$. Wdcts.

In his address "to the reader" the author states that this "essay on angling is not compiled from any work extant, but is a plain and candid narration of matter of fact, founded on many years' experience."

Angler's progress (The). I820. 8\%. See [Boaz, Herman].

Anglers sure guide (The). I 706. $8^{\circ}$. See [Howlett, Robert].

Angler's vade mecum (The). I 700. $16^{\circ}$. See [Chetham, James].

Ang. 45.57 Anglican friar (The), and the fish which he took by hook and by crook. A comic legend; by A. Novice, A. F., \& F. London. I851. I $2^{\circ}$. Front., illustr. titlepage, and plates.

"More comical than piscatorial."-Smith's Bibliog. cat.

Ang. 49.46.7 Ansell, Alfred W. On trawling. London. I 883. 8. pp. 29. (LONDON, Eng. - International fisheries exhibition, I883. [The fisheries exhibition literature, vii. 12.])

Also another edition.

Ang. 49.46.I I Anson, C. V., and Willett, E. H. Oyster culture. Prize essay. London. I $884.8^{\circ} .6$ plates. (LONDON, Eng. - International fisheries exhibition, 1883. [The fisheries exhibition literature, xi. I3.])

Also another edition.

Ang. 45.17 Arber, Edward, editor. An English garner; ingatherings from our history and literature. Vol. i. London. I $877 . \quad 8^{\circ}$.

With reprints of many original title-pages.

"The secrets of angling; by I. D. [John Dennys]," pp. 141-198. 
Ang. 45.2 Armiger, Charles, editor. The sportsman's vocal cabinet; comprising an extensive collection of scarce, curious, and original songs and ballads, relative to field sports. With explanatory notes, and brief sketches of men who have distinguished themselves on the turf or the field. London. I 830 . I $2^{\circ}$.

Contains 25 angling songs.

10417.38 Another copy

*Ang. 18.19 Art of angling (The). London: D. Lewis. I 8 19. I $2^{\circ}$. pp. 35 .

"Not intended for sale."

There is the following ms. note on the second fly-leaf:

" 'Mr. Heseltine of the Covers, Laleham, possessed a copy of this work [printed by W. Davy], which he believed to be unique. On the fly-leaf Mr. H. G. Bohn certifies that he knows of no other copy.' See Bibliotheca piscatoria. This copy is not in the Biblio:piscatoria. It is identical in every particular, saving the imprint, - D. Lewis, 34 Mount street, Grosvenor square. Greville Fennell."

On the title-page is the autograph "Edward L. Soltau."

17466.12 Art of angling (The); eight dialogues in verse. (In Collection of scarce, curious, and valuable pieces, I773, I $2^{\circ}, \mathrm{pp} .269-334$.)

Ang. 45.II Also in the edition of 1785 .

Originally published separately in 1758 , as "The anglers." This edition has become rare. The poem is attributed to Dr. Thomas Scott, a dissenting minister of Ipswich. A large portion of it was appropriated, without acknowledgment, by Lathy, in his poem "The angler."

Ang. 47.32 Artedi, Peter. Ichthyologia; sive, Opera omnia de piscibus. Omnia in hoc genere perfectiora quam antea ulla. Posthuma edidit Carolus Linnæus. 5 pt. in I vol. Lugduni Batavorum. I738. $8^{\circ}$. "Vita," i. (3)-(13).

Contents:-i. Bibliotheca ichthyologica. - ii. Philosophia ichthyologica.iii. Genera piscium. - iv. Synonymia nominum piscium fere omnium. - v. Descriptiones specierum piscium.

A portrait of Linnæus is inserted as a frontispiece.

With the armorial book-plate of Sir. Thos. Gery Cullum, bart., F. R. S.

46.46 Another copy.

Ang. 47.2 Artedi (Petri) Synonymia piscium graeca et latina, emendata, aucta, atque illustrata; sive, Historia piscium naturalis et literaria ab Aristotelis usque aevo ad seculum xIII. deducta, duce Synonymia piscium Petri Artedi. Accedit disputatio de veterum scriptorum hippopotamo. Auctore J. G. Schneider. Lipsiae. 1789. $4^{\circ}$. 3 plates.

This is not Artedi's text, but a commentary on the Greek and Latin names applied by him to fishes in his Synonymia piscium (Ichthyologia, pt. iv.), with illustrative extracts from various authors. 
*Ang. I8.49 Arundo, pseudon. Practical fly-fishing; founded on nature, and tested by the experience of nearly forty years, in various parts of the United Kingdom. With instructions for imitating all the most useful flies; also, remarks on fly-rods, the best woods for them, and the best way of making them, etc. London. I 849. I $6^{\circ}$. pp. iv., 66.

Imperfect: - pp. 3-4, 13-14, wanting.

*Ang. 48.23 Ashworth, Edmund, and Thomas. A treatise on the propagation of salmon and other fish. Stockport, etc. 1853. sm. $8^{\circ}$. pp. 68. Plate.

The title-page is illustrated.

*Ang. 39.66 [Ayrton, William.] The adventures of a salmon in the river Dee; by a friend of the family. With Notes for the fly-fisher in north Wales. London, etc. I 853. I $6^{\circ}$. Illustr. title-page and plates.

The author attempts "to give a summary of the principal difficulties and dangers which attend the propagation and preservation of the salmon in the Dee."

B., J. The epitome of the art of husbandry. 1669. $24^{\circ}$. See [Blagrave, Joseph].

*Ang. 39.12 Baddeley, John. The London angler's book; or, Waltonian chronicle. Containing much original information to anglers, combined with numerous amusing songs and anecdotes of fish and fishing, 'never before published. With an entirely new description of the Thames, the Lea, the Mole, and every river and stream within 20 miles of London worth fishing in. London. I834. I $2^{\circ}$. Front. and 2 plates.

"Coarse and cockney."-Westroood and Satchell.

*Ang. 44.4 Badham, Charles David. Prose halieutics; or, Ancient and modern fish tattle. London. I 854 . I $2^{\circ}$.

Reprinted, in part, from Fraser's magazine.

The author's purpose is " to treat of fish ichthyophagously, not ichthyologically, and to give not fish science, but fish tattle."

Ang. 18.65.5 Bagnall, George. Piscatorial rambles; or, The fisherman's pocket companion. London. I 865 . sm. I $2^{\circ}$.

Originally published in the Sporting gazette.

A review of this work entitled "Bagnall's bungles," is found in Henry Cholmondeley-Pennell's "Fishing gossip," pp. 93-103.

Ang. 18.57 Bailey, William, of Nottingham. The angler's instructor; a treatise on the best modes of angling in English rivers, lakes, and ponds, and on the habits of the fish. London, etc. $1857 . \mathrm{sm} .8^{\circ}$.

"An excellent practical treatise by the best Nottingham angler of his day. There are some marked points of difference between the Nottingham systern of angling, and that in vogue elsewhere."-Westwood and Satchell. 
Ang. 18.57.2 Bailey, William, of Nottingham. The angler's instructor, etc. $2 \mathrm{~d}$ ed. Nottingham, etc. [1866.] I $6^{\circ}$.

Ang. 18.57.3 The same. 3d ed., revised. London, etc. [1879.] sm. $8^{\circ}$. Wdct.

This edition has been considerably enlarged.

*Ang. 18.16.3 Bainbridge, George Cole. The fly fisher's guide. $2 \mathrm{~d}$ ed., with additions. Liverpool. 182.8. sm. $8^{\circ}$. Front. and 8 plates.

The frontispiece and seven of the plates are colored, and include representations of "upwards of forty of the most useful flies, accurately copied from nature."

"One of the text books of the fly-fisher." - Westwood and Saichell.

*Ang. 18.16.5 The same. 4th ed. London. I $840.5 \mathrm{sm} .8^{\circ}$. Front. and 8 plates.

The illustrations are the same as in the previous edition.

Ang. 46.28 Baird, Spencer Fullerton. On the serpents of NewYork; with a notice of a species not hitherto included in the fauna of the state. Albany. I $854.8^{\circ}$. pp. (2), 28. 2 plates.

101.49 Baker, Sir Samuel White. The Nile tributaries of Abyssinia, and the sword hunters of the Hamran Arabs. Philadelphia, etc. I 867. 8\%. pp. xxii., (2), 596. Portrs., maps, and plates.

Chapters 2, 9, and ro contain accounts of fishing.

The illustrations are from original sketches by the author.

I0 $\frac{1}{2} .49-$ The same. $3 \mathrm{~d}$ ed. London. I $868 . \quad 8^{\circ}$. Portrs., maps, and plates.

I. 3739 Also an edition published at Hartford, 1868, with the title, "Exploration of the Nile tributaries of Abyssinia."

Ang. 41.I The same. 4th ed. Philadelphia. r $868 . \quad$ sm. $8^{\circ}$. Maps and plates.

Does not contain the portraits mentioned in the list of illustrations.

I. III0 The same. New ed. London. r883. sm. $8^{\circ}$. Maips and plates.

*Ang. 49.10 Barber, Joseph. Crumbs from the Ronnd table; a feast for epicures. New York. I 866. sm. $8^{\circ}$.

Contents:- The esthetics of epicureanism. - Breakfast. - The fruits of June. - Dinner among the ancients. - Dinner among the moderns. - A few words about puddings. - Vegetarians and vegetalles. - Fishing. - The streams; a poem. - Supper. - October, sentimentally and sensuously considered. - The poetry of good cheer. - Savory stanzas for November. - Epigastric poetry. - A Thanksgiving rhapsody. - The brookside in May.

"For the most part articles which have appeared in the Round tabie, over the signature of ' $\mathrm{J}$. B.," 
*Ang. 16.51.2 [Barker, Thomas.] The art of angling; wherein are discovered many rare secrets, very necessary to be knowne by all that delight in that recreation. London. 1653. sm. $4^{\circ}$. pp. (2), I 8 .

Opposite the title-page 3 sheets are inserted, on each of which are pasted 3 engravings of fishes from the second edition of Walton's Compleat angler.

This work is sometimes found appended to the "Countryman's recreation," I654.

*Ang. 16.51.3 [- $]$ The same. London. 1653. [Reprinted Leeds. I 817.$] \quad 4^{\circ}$. pp. I6.

Lowndes' "Bibliographer's manual" states that of this edition one copy was struck off in $4^{\circ}$, while Westwood and Satchell's "Bibliotheca piscatoria" speaks of I 8 copies, of which 12 were in royal $4^{\circ}$.

*Ang. 16.51.4 Barker, Thomas. The art of angling. Wherein are discovered many rare secrets, very necessary to be known by all that delight in that recreation. London. $165 \mathrm{I}$. [Reprinted 1820.$] 24^{\circ}$. pp. (4), 22 .

" 100 copies."

*Ang. 16.51.5 Barker, Thomas. Barker's delight; or, The art of angling. Wherein are discovered many rare secrets very necessary to be known by all that delight in that recreation, both for catching the fish, and dressing thereof. 2d ed., much enlarged. London. 1657. [Reprinted 1820.] $24^{\circ}$. pp. (2), iv., (12), 40. Diagr.

" 100 copies." - "Biographical notice," pp. i.-iv.

With a reprint of the title-page of the edition of 1659 , which is the edition of 1657 with a new title-page. The edition of 1657 is the first with the title "Barker's delight."

Also inserted in the "Young sportsman's miscellany," London, 1826.

Ang. 16.51.6 The same. 2d ed., much enlarged. London. 1657. [Reprinted 1826.] 24․ pp. (4), 27. Diagr.

*Ang. I6.7I Barlow, Francis. Severall wayes of hunting, hawking, and fishing, acording to the English manner. [ 12 plates] invented by Francis Barlow, etched by W. Hollar. London. I67I. obl. $4^{\circ}$, bound as sm. $4^{\circ}$.

"An extremely scarce work." - Westrwood and Satchell.

The title-page (which is engraved), and each plate, contain an appropriate quatrain.

On the first fly-leaf is pasted a tracing of the engraved title-page of a later edition, where verses beginning "The stag rouz'd before us" take the place of the original quatrain. On the inside of the front cover is pasted the armorial book-plate of William Keale Heseltine, and on the back of the titlepage that of Joseph Crawhall, whose autograph is found on the first fly-leaf.

Ang. 38.16 Barnard, Mordaunt Roger. Sport in Norway, and where to find it. With a short account of the vegetable productions of the country, to which is added a list of the 
Alpine flora of the Dovre fjeld, and of the Norwegian ferns, \&c. London. I864. sm. $8^{\circ}$. Front., map, plate, and wdcts.

In chapter 1 the author describes each province in turn, mentioning the waters where fishing is to be found. Chapter 5 contains "Remarks on the artificial breeding of salmon."

*Ang. 14.96 [Barnes or Berners, Juliana.] The book containing the treatises of hawking, hunting, coat-armour, fishing, and blasing of arms; as printed at Westminster by Wynkyn de Worde, I 496. [With biographical and bibliographical notices by Joseph Haslewood.] Re-printed London. I $810.1 .8^{\circ}$. G. L. Wdcts.

150 copies printed.

The introduction is dated 1811 . - On one side of the last leaf is the device of Wynkyn de Worde, and on the other that of Caxton.

This is a fac-simile reprint of the second edition of the work now commonly known as the Book of Saint Albans, which contains the first printed treatise on angling in the English language. The first edition appeared in 1486 , and does not include the "Trealyse of fysshynge."

*I2471.21 Another copy.

Ang. 14.96.2 Barnes or BERnERs, Juliana. The treatyse of fysshynge wyth an angle, attributed to Dame Juliana Berners. Reprinted from the Book of St. Alban's, [1496]. London. 1827. sm. $8^{\circ}$. pp. xiv., 4I. Front. and plates.

Printed with John Baskerville's type for William Pickering.

34. 66 Another copy.

Imperfect:-p. xiii. wanting. It has been supplied in Ms. from the American edition, 1875 .

Ang. I4.96.3 Barnes or Berners, Juliana. The treatyse of fysshynge wyth an angle, from the Boke of St. Albans, A.D. 1496. Edited by G. W. Van Siclen. [American ed. With a glossary. New York.] 1875 . sq. $16^{\circ}$. Wdcts.

"Reprinted from the Book of St. Albans, and from the edition: London, William Pickering, 1827."

34. 66 Another copy.

*Ang. 14.96.4 Barnes or Berners, Juliana. A treatyse of fysshynge wyth an angle; being a facsimile reproduction of the first book on the subject of fishing printed in England by Wynkyn de Worde at Westminster in 1496 . With an introduction by M. G. Watkins. London. I $880.4^{\circ}$. pp. xiv., (23). G. L. Wdcts.

"One of the best facsimiles ever executed."-Westwood and Satchell.

*VII. I769 Another copy. 
Ang. 14.50 Barnes or BERNERS, Juliana. An older form of the Treatyse of fysshynge wyth an angle attributed to Dame Juliana Barnes. Printed from a MS. in the possession of Alfred Denison; with preface and glossary by Thomas Satchell. London. I883. sm. $4^{\circ}$. pp. (4), viii., 38,(I0).

" 200 copies."

The "Treatyse" as given in this Ms. "differs considerably in orthography, phrase, and sense, from that in the Boke of St. Albans; and Professor Skeat is inclined to assign to it an earlier date than 1450." - Dict. nat. biog.

VII. $1249-T h e$ same. London. 1883. $8^{\circ}$. pp. (4), viii.. I2476.2I 38 , (10). 2 cop.

" 400 copies. Printed solely for presentation to the members of the English dialect society and others."

Ang. 14.96.5 Barnes or BERnERS, Juliana. A treatyse of fysshynge wyth an angle. Originally printed by Wynkyn de Worde in 1496. Edited by "Piscator." Edinburgh. 1885. I $6^{\circ}$. pp. viii., 36. (BIBLIOTHECA curiosa, 31.)

"Privately printed. Limited to 350 copies."

"Bibliography of the Treatyse of fysshynge,",pp, vii.-viii.

Barnwell, pseudon. See Roosevelt, Robert Barnwell.

Ang. 39.60 Barry, William, of London. Moorland and stream. With notes and prose idyls on shooting and trout fishing. London. $1871 . \mathrm{sm} .8^{\circ}$.

“"Trout fishing," pp. 215-299.

"The chapters entitled 'Pictures from an Irish moorland' have been reprinted from the Pall Mall gazetle."

"Ang. 44.6 Barry, William, of London. Sporting rambles and holiday papers. London, etc. [1873.] $16^{\circ}$.

" Rough angling," pp. 3 I-34; "By the river," pp. 79-83; "Trout murder," pp. 89-92.

Bartas, Guillaume DE Saluste, seigneur Du. See Saluste, Guillaume DE, seigneur Du Bartas.

Ang. I.55 [Bartlett, John, of Cambridge.] Catalogue of books on angling, including ichthyology, pisciculture, fisheries, and fishing laws. From the library of a practitioner of more than fifty years' experience in the art of angling. Cambridge. 1882. $4^{\circ}$. pp. (2), 77 . Vigns.

With Ms. notes of bindings.

VII. I28 Another copy.

*Ang. I.56 [-] Supplement. Cambridge. I 886. 4\% ${ }^{\circ}$ pp. (2), 24. Vigns.

With Ms. notes of bindings.

At the end is pasted a copy of Lowell's poem "To Mr. John Bartlett, who had sent me a seven-pound trout." 
*Ang. I.56 [Bartlett, John, of Cambridge.] Second supplementary list of books on fish and fishing. $\mathrm{f}^{\circ}$. ff. (I2). MS.

*Ang. 49.35 Bathurst, Charles. Notes on nets; or, The quincunx practically considered. To which are added miscellaneous memoranda [on natural history]. London, etc. [1838.] sm. I $2^{\circ}$. Diagrs., table, and plates.

"A singular combination of net-making and preaching." - Westrood and Satchell.

Ang. 49.46.9 Beaujon, Anthony. The history of Dutch sea fisheries, their progress, decline, and revival; especially in connection with the legislation on fisheries in earlier and later times. Prize essay. London. I 884. $8^{\circ}$. (LoNDON, Eng.-International fisheries exhibition, 1883. [The fisheries exhibition literature, ix. 5.])

Also another edition.

*Ang. 47.18 Beavan, Reginald. Handbook of the freshwater fishes of India; giving the characteristic peculiarities of all the species at present known, and intended as a guide to students and district officers. London. 1877. 8\%. I 2 plates.

Ang. 49.19 Bell, Hugh, of Edinburgh. Observations upon Scotch fisheries, emigrations, and the means of improving the Highlands and isles. Edinburgh. 1792. $8^{\circ}$ pp. 17.

*Ang. 47.46 Belon (Lat. Bellonius), Pierre. De aquatilibus libri duo. Cum eiconibus ad vivam ipsorum effigiem, quoad ejus fieri potuit, expressis. Parisiis, apud Carolum Stephanum. I 553. obl. $32^{\circ}$. pp. (32), 448 . Wdcts.

Imperfect:- pp. 23-34, wanting. - The last two pages are supplied in ms. Most of the woodcuts have an English translation of the name of the animal which they represent, in Ms.

With the armorial book-plate of Samuel T. Tisdale.

"This volume was once the property of William Penn, and the autograph on the next leaf is supposed to be his. Such was the assertion of the venders, Bartlett \& Welford, N. Y., at the time I purchased it, 1850. S. Tisdale." MS. note on fly-leaf opposite title-page.

Ang. 39.59 [Belton, _ _. The angler in Ireland; or, An Englishman's ramble through Connaught and Munster during the summer of 1833.2 vol. London. I 834. I $2^{\circ}$. Front.

Imperfect : - frontispiece of vol. i. wanting.

The illustrations are from drawings by Lover.

Ang. 38:17 [Belton, _ - ] Two summers in Norway. By the author of "The angler in Ireland." 2 vol. London. 1840. I $2^{\circ}$. 2 maps.

Vol. i. chapters $1,4-6$, and vol. ii. chapters 8-10 treat of angling. The appendix contains a "List of salmon and trout caught in 1837. ". 
Ang. 47.12 Benecke, Berthold. Fische, fischerei, und fischzucht in Ost- und Westpreussen. Auf grund eigener anschauung gemeinfasslich dargestellt. Mit abbildungen von $H$. Braune. Königsberg in $\operatorname{Pr} .1881 .1 .8^{\circ}$ Wdcts. and plates.

One of the plates is colored.

*Ang. I.2I Bennett, John Whitchurch. A selection from the most remarkable and interesting of the fishes found on the coast of Ceylon. From drawings made in the southern part of that island from the living specimens. $2 \mathrm{~d}$ ed. London. $1834.44^{\circ} .30 \mathrm{col}$. plates.

*Ang. 47.34 Bentley, C. S. The sense of pain in fishes. A paper read at a meeting of the Gresham angling society, Nov. 3d, I88I. London. [1881 ?] $8^{\circ}$. pp. (1 7). Wdcts.

Ang. 50.2.4(I8) Berlin, Germ.-Internationale fischerei-ausstellung, 1880. Exhibit of the fisheries and fish culture of the United States of America, at the internationale fischereiausstellung, held at Berlin, April 20, 1880 , and forming a part of the collections of the national museum, made by the United States fish commission. Prepared under the direction of G. B. Goode. Washington. I880. $8^{\circ}$. (U. S. National museum. Bulletin, i 8.)

VIII. 39(18) Another copy.

[Bertram, - angler.] The border angler. See Border angler (The). 1858 . I $6^{\circ}$. Note.

Ang. 49.39 Bertram, James Glass. The harvest of the sea; a contribution to the natural and economic history of the British food fishes. With sketches of fisheries \& fisher folk. 2 ed. London. I 869. $8^{\circ}$. Front., plans, and wdcts.

"List of authorities," pp. 499-501.

“Anglers' fishes," pp. I 29-1 76.

Ang. 49.46.2 Bertram, James Glass. The unappreciated fisher folk; their round of life and labour. London. I883. $8^{\circ}$. pp. viii., 83. Front. (LONDON, Eng. - International fisheries exhibition. [The fisheries exhibition literature, ii. 3.])

Also another edition.

*Ang. 17.87 Best, Thomas. A concise treatise on the art of angling, confirmed by actual experience and minute observations. With several arcana never before made public. To which is added the Compleat fly-fisher. London. 1787. I $2^{\circ}$. Front. 
Ang. 17.87.2 Best, Thomas. A concise treatise on the art of angling, etc. To which is added the game-laws relative to angling, and prognostics of the weather independent of the barometer. 2d ed., corrected and enlarged. London. [1789.] sm. I $2^{\circ}$. Front.

Ang. 17.87.3 The same. 3d ed., corrected and improved. London. 1794. sm. $12^{\circ}$. Front.

The frontispiece has the date 1795 .

Ang. 17.87.4 The same. 4th ed., corrected and improved. London. I798. I $2^{\circ}$. Front.

Ang. 17.87.5 The same. 5th ed., carefully revised. London. I 802 . sm. I $2^{\circ}$. Front.

This edition has a new preface, and some changes have been made in the title-page.

Ang. 17.87.6 The same. 6th ed., carefully revised. London. I 804 . I $2^{\circ}$.

Ang. 17.87.8 The same. [8th ed.], carefully corrected. London. $1808.12^{\circ}$. Front. and vign.

Ang. 17.87.9 The same. [9th ed.], carefully revised, corrected, and enlarged. London. I8IO. I $2^{\circ}$.

This edition has a new preface, and eight pages of "addenda."

Ang. 17.87.10 The same. To which is now added Nobbs's Complete troller. [ [ oth ed.], carefully revised, corrected, and enlarged. London. I $814 . \mathrm{I}^{\circ}$. Front.

In this and the following edition the title reads "The art of angling." The frontispiece has the date 1810.

Ang. 17.87.I I The same. I I th ed., carefully revised, corrected, and re-arranged. London. $1822.12^{\circ}$. Front. and vign.

The frontispiece contains illustrations of thirteen different flies.

Ang. 17.87.1 $\mathrm{I}^{\mathrm{a}}$ Another copy.

Imperfect:- frontispiece wanting.

*Ang. 17.87.14 The same. I 2 th ed., carefully revised, corrected, and re-arranged by John Jackson. London, etc. 1838 . $32^{\circ}$. Front. and vigus.

In this and the following edition Nobbes's "Complete troller" is abridged. The title reads "Best's Art of angling."

*Ang. 17.87.15 The same. I 3th ed., carefully revised, corrected, and re-arranged by John Jackson. I.ondon, etc. I $846.32^{\circ}$. Vigns.

The same as the edition of 1838 , with a new title-page. 
Ang. 8.47 [Bethune, George Washington.] A Waltonian library; or, A list of such works as relate to fish, fishing, Walton, and Cotton. By the American editor of the Complete angler. (Appended to WALTON, Izaak, and CoTton, Charles. The complete angler, I $847,12^{\circ}$, ii. I $5 \mathrm{I}-203$.)

" Founded on Sir Henry Ellis's Catalogue, as reprinted by Pickering."

I4434.8 Another copy.

Ang. 8.59 Also in other Bethune editions of the Complete angler.

*Ang. 8.80

*Ang. 49.40 Bewick, Thomas. Memoir. Embellished by numerous wood engravings, designed and engraved by the author for a work on British fishes, and never before published. [Edited by Jane Bewick.] Newcastle-on-Tyne, etc. I 862 . $8^{\circ}$.

"The engravings are of fish and fishing scenes. . . . Greater progress had been made with the vignettes and tail pieces than with the fish, of which only sixteen blocks and one copperplate were finished. A prospectus containing two specimens of the engravings, and printed on one side of an octavo leaf, was circulated in 1824." - Westwood and Satchell.

V. $2577^{\mathrm{C}}$ The same. New ed., prefaced and annotated by Austin Dobson. London. I887. 1. $8^{\circ}$.

"Memorial edition of Bewick's works. Vol. v."

Bibliotheca piscatoria. 1836. I $6^{\circ}$. See [Pickering, William].

Ang. 18.95 Bickerdyke, John. Sea fishing. With contributions on antipodean and foreign fish, by W. Senior; tarpon, by A. C. Harmsworth; whaling, by Sir H. W. Gore-Booth, bart. London. I $895 . \mathrm{sm} .8^{\circ}$. Front., plates, and zudcts. (The BADMINTON library of sports and pastimes.)

Ang. 22.16 Biermann, A. Neuestes illustrirtes fischereibuch; oder, Anweisung die wilde und zahme fischerei zum vergnügen und nutzen mit erfolg betreiben zu können, nebst belehrung über teichwirthschaft, und andeutungen iber die künstliche fischzucht. Hamm. ' I 865. 8\%. Wdcts.

*Ang. 18.59.4 Bischoff, Wilhelm. Anleitung zur angelfischerei. $2^{e}$ aufl, neu bearbeitet vom bayerischen fischerei-verein. - München. [1883.] $8^{\circ}$. Wdcts. and $4 \mathrm{col}$. plates.

"Most of the artificial flies are identical with our own, and the English names borrowed." - Westwood and Satchell.

*Ang.39.28 Black Palmer, pseudon. Scotch loch-fishing. Edinburgh, etc. 1882. sm. $8^{\circ}$. pp. viii., (2), 81. Wdcts.

Interleaved. 
Ang. 18.42.2 Blacker, William. Art of angling, and complete system of fly making and dying of colours; giving the angler a perfect knowledge of every thing requisite to complete him in this noble art. London. 1842. $24^{\circ}$. pp. (4), 38. Front. and plate.

The title-page is engraved.

The frontispiece contains illustrations "shewing the different processes of the fly before it is finished."

*Ang. 18.55 Blacker, William. Art of Aly making, \&c., comprising angling \& dyeing of colours. With descriptions of flies for the season of the year as they come out on the water. Rewritten \& revised by the author. London. I 855 . I $8^{\circ}$. Front. and 20 plates.

The title-page is engraved, and the 17 plates of flies are colored.

This was published in 1843 as "Blacker's catechism of fly-making, angling, and dyeing."

"A strange medley of practical usefulness and rhapsodical extravagance." - Westwood and Satchell.

Blackwater chronicle (The). I853. I $2^{\circ}$. See [Kennedy, Pendleton].

Ang. 60.5 [Blagrave, Joseph.] The epitome of the art of husbandry, comprising all necessary directions for the improvement of it; viz. plowing, sowing, directions for the use of the angle, ordering of bees. Together with the gentlemans heroick exercise, discoursing of horses; of oxen, sheep, cows, their diseases and remedies, etc. By J. B. London. 1669. $24^{\circ}$. Engr. title-page. 196.

"Brief experimental directions for the right use of the angle," pp. 182-

With the autograph of Joseph Crawhall on the back of the engraved titlepage.

Ang. 49.40.10 Blake, H. P. Improved facilities for the capture, economic transmission, and distribution of sea fishes. Prize essay. London. I 884. $8^{\circ}$. pp. 52. Wdcts. and 4 plates. (LoNDON, Eng. - International fisheries exhibition, I883. [The fisheries exhibition literature, x. 2.])

Also another edition.

*Ang. 39.25 Blakey, Robert. The angler's complete guide to the rivers and lakes of England [and Wales]. London, etc. I 853 . sm. $12^{\circ}$. Front. zine."

"The substance of two chapters appeared in the London Sporting maga. The same. London. $1856 . \mathrm{sm}$. I $2^{\circ}$.

The 1853 edition with a new litle-page. 
*Ang. 39.32 Blakey, Robert. The angler's guide to the rivers \& lochs of Scotland. London, etc. 1854. I $6^{\circ}$. Front. and vigns.

*Ang. 45.4 Blakey, Robert, editor. The angler's song book. London, etc. I $855 . \quad$ I $6^{\circ}$.

A "general collection of fishing songs, embodying the poetical warblings of piscatorians of all parts of the kingdom."

Ang. 18.54.4 Blakey, Robert. Angling; or, How to angle and where to go. London, etc. I 854 . I $6^{\circ}$. Front. and plates.

This work contains portions of his "Hints on angling," 1846 . It forms one of a series called "Books for the country."

*Ang. 18.54.6 The same. New ed. London, etc. 1862. I6\%. Front. and plates.

*Ang. 18.46 [Blakey, Robert.] Hints on angling, with suggestions for angling excursions in France and Belgium; to which are appended some brief notices of the English, Scottish, and Irish waters. By Palmer Hackle [pseudon.]. London. I 846.8 .

Imperfect:- pp. i., ii., wanting.

Portions of this work were reproduced in the author's "Angling, or, How to angle and where to go," 1854 .

34.52 Another copy.

*Ang. 3.2 Blakey, Robert. Historical sketches of the angling literature of all nations; to which is added a bibliography of English writers on angling, [by J. R. Smith]. London. 1856 . $\mathrm{sm} . \mathrm{I} 2^{\circ}$.

Described by Westwood and Satchell as inaccurate and of little value, except for the "Bibliographical catalogue" appended to it by the publisher.

$3 \frac{1}{2} .6 \quad$ Another copy.

*Ang. 44.8 Blakey, Robert. Old faces in new masks. London. 1859. sm. $8^{\circ}$. Front. and engr. title-page.

Contents:- Fishwives. - An autumn day with some of the scholastic doctors of the middle ages. - A few words about eels. - Hermit literature. Notes of an antiquary on the symbolical representation of fish. - John Paterson's nıare. - The "Dances of death." - Historical sketch of British caricature. - A few words on pike. - Dr. Paley's Natural theology. - Oysters. On the generalities of literature and art. - Days on the Tweed sixty years ago, from the note-book of an octogenarian. - Lobsters and crabs.

The illustrations are "'designed \& etched by George Cruikshank."

Ang. 49.46.7 Bloomfield, J. C. The fisheries of Ireland. London. 1883. $8^{\circ}$. pp. 33. (LoNdon, Eng.-International fisheries exhibition, I883. [The fisheries exhibition literature, vii. 3.])

Also another edition. 
Ang. 45.19.2 [Boaz, Herman.] The angler's progress; a poem. Developing the pleasures the angler receives from the dawn of the propensity in infancy, till the period of his becoming a complete angler. Newcastle. I820 [1824]. sm. $8^{\circ}$. pp. 8. Vign.

Signed "H. B."

According to Crawhall, and Westwood and Satchell, this was written in 1789 , and published in a detached form. In 1824, 296 copies were printed for Emerson Charnley, antedated 1820 in order to form the first of the "Newcastle fisher's garlands" with which it was afterwards reprinted.

The vignette on the title-page figures in Bohn's edition of Walton's "Complete angler," 1856, as Bewick's. A portrait of Robert Roxby "drawn by E. Train, 1830," and one of Bewick have been inserted.

Ang. 48.3 Boccius, Gottlieb. Fish in rivers and streams. A treatise on the production and management of fish in fresh waters by artificial spawning, breeding, and rearing; showing also the cause of the depletion of all rivers and streams. London. I $848 . \quad 8^{\circ}$. pp. viii., 38.

Ang. 48.4 Boccius, Gottlieb. A treatise on the management of fresh-water fish, with a view to making them a source of profit to landed proprietors. [With an appendix containing twenty-three German recipes for cooking fresh-water fish.] London. I $841.8^{\circ}$. pp. vi., 38. $W d c t$.

Book (The) containing the treatises of hawking, hunting, coat-armour, fishing, and blasing of arms. I 8 IO. $8^{\circ}$. See [Barnes, Juliana].

*Ang. 47.44 Book of fishes (The). Class pisces. Published by the society for promoting Christian knowledge. London. 1834. $24^{\circ}$. Front. and wdcts.

"The art of angling," pp. 145-160.

Book of Saint Albans (The). I8 10. $8^{\circ}$. See [Barnes, Juliana].

Ang. 1.5 B Book of sports (The), British and foreign; devoted to the pictorial illustration of the pursuits of the sportsman in every quarter of the globe. 1843. London, etc. [1843.] $4^{\circ}$. Front., engr. title-page, portrs., plates, and vigns.

The illustrations are engravings after Landseer, Cooper, Herring, etc.

"The fisherman;" by Sylvanus Swanquill, pp. 12-14. - "Pike fishing in Germany"; by T. Hood, pp. 37-40. - "My Glendale friend, Will Reedy O "; a poem by Stephen Oliver [W. A. Chatto], p. 59.

Ang. 18.35.2 Boosey, Thomas. Anecdotes of fish and fishing. London, etc. I $887 . \quad 8^{\circ}$.

This is a reprint of his "Piscatorial reminiscences," published in 1835 , but does not contain Pickering's "Catalogue of books on angling." 
Ang. 18.35 [Boosey, Thomas.] Piscatorial reminiscences and gleanings by an old angler and bibliopolist. To which is added a Catalogue of books on angling [by William Pickering]. London. 1835. $16^{\circ}$. Front. and wdcts.

The preface is signed "T. B."

The "Catalogue" has a special title-page dated 1836 .

This was published without the "Catalogue" in 1887 , with the title "Anecdotes of fish and fishing."

Booth, Sir Henry William Gore, 5th bart. See GoreBooth.

*Ang. 39.33 Border angler (The); a guide-book to the. Tweed and its tributaries and the other streams commanded by the north British railway. Edinburgh, etc. 1858. 16 $6^{\circ}$ Map.

Halkett and Laing attribute this work to a Mr. Bertram.

Ang. 18.75.3 Borne, Max vON DEM. Taschenbuch der angelfischerei. $2^{\mathrm{e}}$, umgearbeitete aufl. Berlin. 1882. I $6^{\circ}$. Wdcts.

"Litteratur," pp. 218-221.

Ist edition, 1875, with the title "Illustrirtes handbuch der angelfischerei."

Ang. 38.6 Borne, Max vON DEM. Wegweiser für angler durch Deutschland, Oesterreich, und die Schweiz. Berlin. 1877 . sm. I $2^{\circ}$.

Ang. 3.6 Bosgoed, D. Mulder. Bibliotheca ichthyologica et piscatoria. Catalogus van boeken en geschriften over de natuurlijke geschiedenis van de visschen en walvisschen, de kunstmatige vischteelt, de visscherijen, de wetgeving op de visscherijen, enz. Haarlem. I874. $8^{\circ}$.

The preface is in both Dutch and French, and there is a French title-page.

V. I5II Another copy.

*Ang. 38.I5 Bowden, John, of Rokeby. The naturalist in Norway; or, Notes on the wild animals, birds, fishes, and plants of that country. With some account of the principal salmon rivers. London. 1869 . sm. $8^{\circ}$. Front. and 7 plates.

Chapter 27 contains "The fisheries of Norway;" "The herring fishery;" "The cod fishery;" "Salmon and salmon-rivers in Norway."

*Ang. 17.58.4 Bowlker, Charles. The art of angling, and compleat fly-fishing. Describing the different kinds of fish, also various kinds of baits, and the great diversity of flies that nature produces. To which are added directions for making artificial flies. Birmingham, etc. $1786 . \mathrm{sm} .12^{\circ}$. Front.

The frontispiece of this copy has been colored by hand.

The first edition (1758?) appeared under the name of Richard Bowlker. The subsequent editions bear the name of his son Charles, who has considerably altered and partly rewritten the work. 
Ang. 17.58.6 Bowlker, Charles. The art of angling; or, Compleat fly-fisher, etc. Birmingham. I 792. I $2^{\circ}$.

Westwood and Satchell assign a frontispiece to this edition, while none is mentioned in their collation of the edition of 1786.

*Ang. 17.58.8 The same. New ed. Ludlow. I814. $24^{\circ}$. Front. The title reads "The art of angling; or, Complete fly \& bottom-fisher."

*Ang. 17.58.9 — The same. Greatly enlarged and improved. Ludlow. 1826. $16^{\circ}$. Front. and wdcts.

The title reads " Bowlker's Art of angling," etc.

In this and the following editions the work has been rewritten by an unknown hand. The frontispieces contain colored illustrations of thirty different fiies.

*Ang. 17.58.10 The same. Greatly enlarged and improved. Ludlow. 1829. I $6^{\circ}$. Front. and wdcts.

Ang. 17.58.1 I - The same. Greatly enlarged and improved. Ludlow. I 833 . I $6^{\circ}$. Front. and wdcts.

*Ang. 17.58.12 - The same. Ludlow. $1839.16^{\circ}$. Front. and wdcts.

Ang. 49.4I Brabazon, Wallop. The deep sea and coast fisheries of Ireland, with suggestions for the working of a fishing company. Illustrated by William Cooper. Dublin, etc. I $848.8^{\circ}$. Front., plates, and plans.

Ang. 49.43 Bradfield, H. Angling associations; with code of rules for their management. (In HERBERT, David, editor. Fish and fisheries, I $883,8^{\circ}$, pp. 253-26I.)

*Ang. 47.42 Braithwaite, George Foster. Fishes and their food; being a paper on the salmon family, with illustrations of their habits, taken principally from the counties of Westmorland and Cumberland. Read before the Kendal literary and scientific society, Feb. 9, I 863. Kendal. I 863. i $6^{\circ}$. pp. 32.

*Ang. 39.18 Braithwaite, George Foster. The salmonidæ of Westmorland, Angling reminiscences, and Leaves from an angler's note book. London, etc. I $884 . \mathrm{sm} .8^{\circ}$. Front. and plates.

Series of papers originally published in the Westmorland gazette.

Brayton, Alembert Winthrop. Contributions to North American ichthyology. See Jordan, D. S. Contributions to North American ichthyology. I877, etc. $8^{\circ}$. Note.

Ang. 1.24(ii) Brevoort, James Carson. Notes on some figures of 36.68 Japanese fish, taken from recent specimens by the artists I3.I4 of the U. S. Japan expedition. Io col. plates. (In Perry, M. C. Narrative of the expedition of an American squadron to the China seas and Japan, $1856,4^{\circ}$, ii. $253^{-}$ 288.) 3 cop.

r3.25 Also in other edition of 1856 . 
46.5 Brevoort, James Carson. Notes on some figures of Japanese fish, etc. [Washington. I 856.] $4^{\circ}$. pp. 36. $10 \mathrm{col}$. plates.

Bridgman, Henry Hewitt. A central wholesale fish market for London. 1884. $8^{\circ}$. See Cayley, J. J., and Bridgman, H. H.

*Ang. 39.r9 Briggs, John Joseph. The Peacock at Rowsley, where Andrew, Alexis, and the naturalist met; and what came of their visit. London, etc. I $869 . \quad$ sm. $8^{\circ}$. pp. viii., 70. Front.

Originally published in the Field.

"A gossiping book about fishing and country life, descriptive of a wellknown resort of anglers at the junction of the Wye and Derwent."-Dict. nat. biog.

British angling flies. I862. I $6^{\circ}$. See [Theakston, Michael].

*Ang. 18.85.5 Bromley-Davenport, William. Sport. Fox-hunting, salmon-fishing, covert-shooting, deer-stalking. Illustrated by H. H. Crealocke. London. 1885. sm. $4^{\circ}$. Front., plates, and wdcts.

The work is edited by the author's wife, Augusta Bromley-Davenport.

"Salmon-fishing," pp. 4I-80.

Ang. 17.40 [Brookes, Richard.] The art of angling, rock and seafishing. With the natural history of river, pond, and seafish. London. I 740 . sm. I $2^{\circ}$. Wdcts.

In the angling part of this work, the author obtained much assistance from Chetham's "Angler's vade mecum."

Ang. 17.40.3 Brookes, Richard. The art of angling; now improved, with additions, and formed into a dictionary. In two parts; the whole forming a sportsman's magazine, and comprizing all that is curious and valuable in the art of angling. London. $1766 . \mathrm{sm} .12^{\circ}$. Front. and wdcts.

This edition is said to have been edited by Moses Browne.

Ang. 17.40.5 The same. $3 \mathrm{~d}$ ed., with great improvements. London. 1770 . sm. I $2^{\circ}$. Front. and wdits.

Ang. 17.40.6 The same. 4th ed., with great improvements.

London. 1774. sm. $12^{\circ}$. Front. and wdcts.

Ang. 17.40.7 The same. 5th ed., with great improvements.

Dublin. $1778 . \mathrm{sm} .12^{\circ}$. Front. and wdcts.

Ang. 17.40.8 The same. 5th ed., with great improvements.

London. I781. I $2^{\circ}$. Front. and wdcts.

Ang. 17.40.12 The same. New ed. London. I793. I $2^{\circ}$.

Front. and wdcts.

Half-title:- "Brookes's Art of angling, or, Sportsman's magaxine."

Ang. 17.40.13 The same. New ed. London. 1799. sm. $12^{\circ}$. Front. and wdets. 
Ang. 17.40.14 Brookes, Richard. The art of angling, etc. New ed., corrected. London. I 801 . I $2^{\circ}$. Front. and wdcts.

Has the same half-title as the 1793 edition.

Ang. 49.43 Brotherston, Andrew. The salmon disease. Plate. (In HERBERT, David, editor. Fish and fisheries, $1883,8^{\circ}$, pp. I 72-179.)

Ang. I.7 Broussonet, Pierre Marie Auguste. Ichthyologia, sistens piscium descriptiones et icones. [Decas i.] Londini, etc. [I782.] $4^{\circ}$. pp. (6), iv., (4I). Vign. and I I plates.

No more published.

46.50 Another copy.

*Ang. 18.45 [Brown, Jolin J.] The American angler's guide; being a compilation from the works of popular English authors, from Walton to the present time, with the opinions and practices of the best American anglers. Containing every variety of mode adopted in ocean, river, lake, and pond fishing, \&c. By an American angler. New-York. I $845.24^{\circ}$. Front. and 2 plates.

Ang. I8.45.4 [Brown, John J.] The American angler's guide; or, Complete fisher's manual for the United States. Containing the opinions and practices of experienced anglers of both hemispheres, with the various modes adopted in ocean, river, lake, and pond fishing, etc. 4th ed., revised, corrected, and greatly improved, with the addition of a second part. New York. I 857 [cop. I 845]. 8'. Front., 24 plates, and wdcts.

Imperfect. - engr. title-page of pt. ii. wanting.

The second part contains over 100 pages of additional information.

Ang. 18.45.5 The same. 5 th ed., revised and greatly enlarged and improved, with the addition of a third part, containing a more particular description of southern and western fishes, and other matter of interest to the angler. New York. $1876.8^{\circ}$. Front., 27 plates, and wdcts.

VII. 428 Another copy.

34.157 Brown, M. B., \& c0., publishers. Fur, fin, and feather; a compilation of the game laws of the principal states and provinces of the United States and Canada, with a list of hunting and fishing localities, and other useful information for gunners and anglers. [4th ed.] New York. I87 I. $8^{\circ}$.

Ang. 49.6 [-] The same. [5th ed.] New York. [1872, cop. 1870.] $8^{\circ}$. 
Ang. 48.25 Brown, William, of Perth. The natural history of the salmon, as ascertained by the recent experiments in the artificial spawning and hatching of the ova and rearing of the fry, at Stormontfield, on the Tay. Glasgow, etc. 1862. I $6^{\circ}$. Front. and plate.

Half-title: - "The Stormontfield experiment on the salmon."

*Ang. 44.2I [Brown, William Linn.] Scribblings and sketches, diplomatic, piscatory, and oceanic. By a fisher in small streams. 2d ed., with additions. Philadelphia. I 844. sm. $8^{\circ}$.

The "piscatory" sketches consist of four humorous letters signed "Isaac Walton, Jr."

*Ang. 45.6 [Browne, Moses (1704-1787).] Piscatory eclogues; an essay to introduce new rules and new characters into pastoral. To which is prefix'd, a discourse in defence of this undertaking, with practical and philosophical notes. London. I 729. sm. $8^{\circ}$.

" Each eclogue is dedicated to a friend or patron. . . . . Virgil and Theocritus appear to have been Browne's models."-Westwood and Satchell.

Ang. 45.7 Browne, Moses (1704-1787). Angling sports, in nine piscatory eclogues; a new attempt to introduce a more pleasing variety and mixture of subjects and characters into pastoral, on the plan of its primitive rules and manners. With an essay in defence of this undertaking. $3 \mathrm{~d}$ ed., corrected and very much improved. London. 1773 . $16^{\circ}$. Front.

"Best edition." - Lowndes.

The first edition has the title, "Piscatory eclogues."

V. 66 Buckland, Francis Trevelyan. Curiosities of natural history. 4 series. London. I877, '75-77. $\mathrm{sm} .8^{\circ}$. Fronts., plates, and wdcts.

Series i., ii. are "Popular ed."

"Fish and fishing," i. 227-290. The other volumes also contain many notes on fishes and fishing.

Ang. 46.18 The same. 4 series. London. 1877, '75-78. $16^{\circ}$. Fronts., plates, and wdcts.

Series i.-iii. are "Popular ed."

*Ang. 47.29 [Buckland, Francis Trevelyan.] A familiar history of the British fishes. Published by the society for promoting Christian knowledge. London. [I859.] 160. Wdcts.

Ang. 48.ro Buckland, Francis Trevelyan. Fish hatching. London. 1863. sm. $8^{\circ}$. Front. and wdcts.

Books on pisciculture, pp. 266-268.

"The substance of this little book was delivered in the form of a lecture, at the royal institution, Albemarle street, the I7th of April, I863." 
Ang. 46.9 Buckland, Francis (Trevelyan). Log-book of a fisherman and zoölogist. 3d thousand. London. I876. $8^{\circ}$. Front., plates, and wdcts.

"Most of the articles have been published in Land and water."

"Fish at Great Grimsby docks," pp. 79-95; "Netting the fish in the Serpentine," pp. 151-162; "The Brighton aquarium," pp. 193-218; “Injury to a submarine telegraph cable by a fish," pp. 275-279; "John Hunter revised," pp. 378-400.

Ang. 48.26 Buckland, Francis (Trevelyan). Manual of salmon and trout hatching; or, An explanation of the fish-hatching apparatus at the royal horticultural gardens, the South Kensington museum, zoölogical gardens, \&c. London. I 864. sm. $8^{\circ}$. pp. $36 . \quad W d c t$.

Ang. 47.30 Buckland, Francis (Trevelyan). Natural history of British fishes; their structure, economic uses, and capture by net and rod. Cultivation of fish-ponds, fish suited for acclimatisation, artificial breeding of salmon. London. [I88I.] I $6^{\circ}$. Wdcts.

The author, in the preface, refers to his "Familiar history of the British fishes" as the first edition. The work, however, has been entirely rewritten.

*Ang. 46.8 Buckland, Francis (Trevelyan). Notes and jottings from animal life. [Edited by G. C. Bompas.] London. 1882. 8\%. Port., plate, and wdcts.

"The great sea-serpent," pp. 384-414.

The substance of these papers originally appeared in Land and water. Several of them contain references to fishing.

Bund, John William Willis. See Willis-Bund.

Burdett-Coutts, Angela Georgina Bartlett, ist baroness. Two of the essays received on the best means to kill fish with the least cruelty. See Two of the essays, etc. 1874. $8^{\circ}$.

*Ang. 18.67.2 Burgess, Joseph Tom. Angling; a practical guide to bottom fishing, trolling, spinning, and fly-fishing. With a chapter on sea fishing. London, etc. [1867.] i $6^{\circ}$. Front., wdcts., and plates.

*Ang. 18.78.5 Burke, Ulick John. The boy's Walton; a discourse on fishing. London, etc. 1878 . I $6^{\circ}$. Wdcts.

*Ang. 12.27 Burnand, Francis Cowley. The incompleat angler; after Master Izaak Walton. Illustrated by Harry Furniss. London. I887. $8^{\circ}$. Front. and wedcts.

AL 994.18 Burroughs, John. Locusts and wild honey. Boston. I88 I [cop. I 879]. 160.

Contents : - The pastoral bees. - Sharp eyes. - Strawberries. - Is it going to rain? - Speckled trout. - Birds and birds. - A bed of boughs. - Birds'nesting. - The halcyon in Canada.

*Ang. 46.17 The same. [7th ed.] Boston. I885 [cop. I 879]. I $6^{\circ}$. 
Bush wanderings of a naturalist. 186r. 16 . See [Wheelwright, H. W.].

Ang. 47.28 Bųshnan, John Stevenson. Fishes, particularly their structure and economical uses. London. [18-.] Port. of Salvianus, engr. title-page, wdcts., and $32 \mathrm{col}$. plates. (In JARDIne, Sir William, bart. The naturalist's library, [18- ], 1 $6^{\circ}, \mathrm{xxxv}$.)

"Memoir of Hippolito Salviani," pp. 17-43.

46.47 Also in the edition of $\mathbf{1} 853$.

By the loch \& river side. 1866. obl. $4^{\circ}$. See [Finlay, K. J.].

C., H., Esq. The fisher boy. [1808.] 160. See [Ireland, S. W. H.].

C., I. E. B. Facts and useful hints relating to fishing and shooting. I $874 . \quad 8^{\circ}$. See [Cox, I. E. B.].

Cairn Lorgh, pseudon. See Lorgh, Cairn, pseudon.

*Ang. 47.39 Cairncross, David. The origin of the silver eel; with remarks on bait \& fly fishing. London. I862. $16^{\circ}$. Front.

The author maintains " that the progenitor of the silver eel is a small beetle."

Calabar (01d), pseudon. See Old Calabar, pseudon.

Ang. 50.I3 California-Commissioners of fisheries. Report for 1870/71-1880. 6 pam. Sacramento, etc. 1872-81. $8^{\circ}$.

Emb. r6.6I Camerarius, Joachim (I 534-I 598). Symbolorū \& emblematum centuria una - quarta collecta. In quib' rariores proprietates historiæ ac sententiæ memorabiles non paucæ breviter exponuntur. 4 pt. in I vol. Francofurti. I66I72. sm. $4^{\circ}$. Engrs.

Contents:-i. Ex re herbaria. 1661.-ii. Ex animalibus quadrupedibus. I66r. - iii. Ex volatilibus et insectis. 1672. - iv. Ex aquatilibus et reptilibus; a Joachimo Camerario coepta, absoluta post ejus obitum a Ludovico Camerario. I66r.

The title-pages are engraved.

Ang. 60.7 - The same. Moguntiæ. I668. I6 $6^{\circ}$ pp. (8), 201, 204, 204, 201. Engrs.

Also with an engraved title-page.

With Ms. notes on the fly-leaves.

Campbell, Lady Colin. See Campbell, Gertrude Elizabeth BLOOD, Lady.

*Ang. 47.27 Campbell, Gertrude Elizabeth BLood, Lady. A book of the running brook, and of still waters. London. 1886. $16^{\circ}$.

Conten/s:- Eels and elvers. - Water wolves. - Carp culture. - Cousins of the carp. - Perch. - Small fry. - Fish-ponds.

Originally published in the Saturday review, $1885-86$. 
Ang. 49.46.5 Campbell, James Duncan. The fisheries of China. London. 1883. $8^{\circ}$. pp. $20+$. (London, Eng. - International fisheries exhibition, I883. [The fisheries exhibition literature, v. 4.])

"A short summary of some of the principal points in the Chinese exhibits." - Page 5 .

Also another edition.

*Ang. 49.23 Campbell, John (1708-1775). An exact and authentic account of the greatest white-herring-fishery in Scotland, carried on yearly in the island of Zetland, by the Dutch only. To which is prefixed a description of the island, its situation, produce, the manners and customs of the inhabitants, with their method of trading with the Dutch. Reprinted from the edition of 1750 . Edinburgh. I885. sm. $8^{\circ}$. pp. (2), 6, iv., 33 .

"I I copies printed. No. $89 . "$

With a reprint of the original title-page.

Some copies of the $2 \mathrm{~d}$ ed., published in $\mathrm{I} 753$, have the title "A true and exact description of the island of Shetland," elc.

VII. I904 Another copy.

"No. 51."

Ang. 50.1.2 Canada-Commissioner of fisheries. Report for I875I878. 4 vol. Ottawa. I876-79. $8^{\circ}$. Maps, plate, and plans.

"Supplement to the report of the minister of marine and fisheries, 1875I878."

Also another set in the Canadian Documents.

Ang. 50.r.2 Canada-Commissioner of fisheries. Statements connected with the report of the commissioner for I879, I88I.

2 vol. Ottawa. 1880-82. $8^{\circ}$. Plans.

"Supplement no. 2 to the report of the minister of marine and fisheries, I879, I 88I."

Also a more complete set in the Canadian Documents.

Ang. 50.I.6 Canada-Department of marine and fisheries. List of lights and fog signals on the coasts, rivers, and lakes of the Dominion of Canada, 31st Dec. I880. Ottawa. I881. $8^{\circ}$.

Also other years in the Canadian Documents.

Ang. 50.1.5 Canada - Department of marine and fisheries. List of vessels on the registry books, 3 Ist Dec. I877. Ottawa. $1878.8^{\circ}$.

"Supplement no. 4 to report of the department for $1877 . "$

Can. Doc. I0.62.5(1877) Another copy.

Ang. 50.I Canada - Department of marine and fisheries. Annual report for I868-74, I877-80. I I vol. in Io. Ottawa. I 869-81. $8^{\circ}$. Plans.

Also a more complete set in the Canadian Documents. 
Ang. 50.I.4 Canada - Department of marine and fisheries. Reports of the boards of steamboat inspection and examiners of masters and mates, the Toronto, Montreal, Quebec, and Pictou harbour commissioners, the pilotage authorities, etc., with statement of wrecks and casualties and list of rewards for saving life, chiefly to 3 Ist Dec. I879, I880. 2 vol. Ottawa. I880-8I. $8^{\circ}$.

"Supplement no. I to the report of the department for 1879 , I880."

Also a more complete set in the Canadian Documents.

Ang. 50.1.7 Canada-Meteorological office. Report for I877-1880. 4 vol. Ottawa, etc. I 878-82. $\quad 8^{\circ}$. Map.

The report for 1877 is " supplement no. 3 to the report of the department of marine and fisheries, $1877 . "$

Met. $\mathbf{3 2 0}$ Also a more complete set.

Ang. 50.r.2 Canada-Superintendent of fish culture. Report on fish-breeding, I877-79. 3 vol. Ottawa. I 878-80. $8^{\circ}$. Plans.

Appended to the reports of the commissioner of fisheries.

Ang. 50.1.8 - The same. I881. Ottawa. I 882. $8^{\circ}$.

"Supplement no. 2 to the report of the department of marine and fisheries."

Earlier reports on this subject are appended to the reports of the commissioner of fisheries, $1874-76$; later reports were published with the "Reports" and "Fisheries statements" of the department of fisheries; these are contained in the Canadian Documents.

*Ang. 48.29 Capel, Charles C. Trout culture; a practical treatise on the art of spawning, hatching, and rearing trout. London. $1877 . \quad$ I $6^{\circ}$. pp. (2), 93.

Ang. 12.32 Cargill, Alexander. Izaak Walton. [New York, etc. 1893.] 8\%. pp. (14). Illustr.

Scribner's magazine, 1893, xiv. 267-280.

*Ang. 18.48 Carpenter, William, angler. The angler's assistant. Comprising practical directions for bottom-fishing, trolling, \&c., with ample instructions for the preparation \& use of tackle and baits, a descriptive account of the habits and haunts of fish, and a geographical and ichthyological account of the principal rivers \& streams in England. London. I 848 . I $6^{\circ}$. Wdcts.

*Ang. 18.48.2 - The same. London. 1852. I $6^{\circ}$. Col. front. and wdcts.

This is the 1848 edition with a new title-page. The frontispiece of flies is taken from the "Angler's hand-book," published by R. Tyas in 1838 .

Ang. 18.79.2 Carpentier, Jules. La pêche raisonnée et perfectionnée du pêcheur fabricateur, toutes lignes, cinquante pêches différentes. Paris. I 879. I $8^{\circ}$. Wdcts. 
Ang. 49.46.II Carr, T. F. Robertson. The best means of increasing the supply of mussels and other molluscs, oysters excepted, used either for bait or food. Prize essay. London. 1884. 8\%. pp. 32. (LoNDON, Eng.-International fisheries exhibition, I 883. [The fisheries exhibition literature, xi. [ 5.])

Also another edition.

*Ang. r8.18.2 Carroll, W., of Edinburgh. The angler's vade mecum ; containing a descriptive account of the water flies, their seasons, and the kind of weather that brings them most on the water. To which is added a description of the different baits used in angling, and where found. Edinburgh. I $8 \mathrm{I} 8 . \mathrm{sm}, 8^{\circ}$. Front. and I col. plates.

The 12 plates are colored by hand, and contain representations of 195 different flies.

I5372.25 Carter, Robert. A summer cruise on the coast of New England. Boston, etc. I $864 . \quad$ I $2^{\circ}$ or $\mathrm{sm} .8^{\circ}$.

This record of a fishing voyage originally appeared in the form of letters to the New York tribune.

*Ang. 28.1 - The same. Boston. 1870 [cop. 1864]. $12^{\circ}$ or sm. $8^{\circ}$.

Ang. 18.74 [Cartwright, William, of Westbury-upon-Trym.] Facts and fancies of salmon fishing. With original illustrations. By Clericus. London, etc. I 874 . sm. $8^{\circ}$. Front., plates, and wdets.

Ang. 18.54.8 [Cartwright, William, of Westbury-upon-Trym.] Rambles and recollections of a fly-fisher. With an appendix, containing ample instructions to the novice, inclusive of flymaking, and a list of really useful flies. By Clericus. London. I $854 . \mathrm{sm} .8^{\circ}$. Front., vign., and plates.

Westwood and Satchell state that the eight engravings are by the Rev. John Eagles, to whom the work is dedicated.

With occasional marginal notes in pencil by S. T. Tisdale, whose autograph is found on the second fly-leaf.

9425.59 Cathrall, William. The history of Oswestry; comprising the British, Saxon, Norman, and English eras, the topography of the borough, and its ecclesiastical and civic history. With notices of botany, geology, statistics, angling, and biography. To which are added sketches of the environs. Illustrated by Percy Cruikshank after sketches by Robert Cruikshank. Oswestry. [1855.] 8\%. Front., plates, and wdcts.

"Angling," pp. 209-213.

Ang. 39.9 - The same. [Cheap ed.] Oswestry. [1867.] sm. $8^{\circ}$. Front., plates, and wdcts.

A paginal reprint of the first edition. 
VIII. 39I(x) Cayley, J. J., and Bridgman, Henry Hewitt. A central wholesale fish market for London. Plates and plans. (In London, Eng.-International fisheries exhibition, 1883. The fisheries exhibition literature, I $884,8^{\circ}, x .469-$ 524.)

*Ang. 48.16 Central fishcultural society. Proceedings of the society at their Ist annual meeting, held at Chicago, Ill., October Ist and $2 \mathrm{~d}$, I 879. Chicago. I879. $16^{\circ}$.

Ang. 49.46. II Chambers, William Oldham. The introduction and acclimatisation of foreign fish. Prize essay. London. I 884. $8^{\circ}$. pp. I I. (LONDON, Eng. - International fisheries exhibition, I883. [The fisheries exhibition literature, xi. I7.])

Also another edition.

Ang. 49.46. II Chambers, William Oldham. The propagation of freshwater fish excluding salmonidæ. Prize essay. London. 1884. $8^{\circ}$. pp. 10. 2 plates. (LONDON, Eng.International fisheries exhibition, I883. '[The fisheries exhibition literature, xi. 7.])

Also another edition.

Ang. 49.46.II Chambers, William Oldham. The propagation of the salmonidæ. Prize essay. London. i 884. 8०. pp. I4. 3 plates. (London, Eng. - International fisheries exhibition, 1883 . [The fisheries exhibition literature, xi. 3.])

Also another edition.

Charfy, Guiniad, pseudon. See Smeeton, George.

Ang. 45.10 Charleton, T. W. The art of fishing; a poem. North Shields. I8I9. $8^{\circ}$. pp. 80.

"Printed for the author."

"An attempt, not quite so successful as that of John Dennys, to give a rhymed compendium of the mechanism of the art. It is smoothly written, but matter of fact." - Westwood and Satchell.

Ang. 49.46.9 Chater, F. J. Talfourd. The relations of the state with fishermen and fisheries, including all matters dealing with their protection and regulation. Prize essay. London. I884. $\quad 8^{\circ}$. pp. 78. (LONDON, Eng. - International fisheries exhibition, I883. [The fisheries exhibition literature, ix. 4.])

Also another edition.

*Ang. 18.35.4 [Chatto, William Andrew.] The angler's souvenir; by P. Fisher [pseudon.], assisted by several eminent piscatory characters. London. $1835.16^{\circ}$. Front. and plates.

The title-page is engraved, and each page has a woodcut border. The illustrations are by Beckwith and Topham. 
Chatto, William Andrew. The fisher's garland for I 835, etc. See Fisher's garland (The). I82I, etc. $8^{\circ}$. Note.

*Ang. 39.27 [Chatto, William Andrew.] Rambles in Northumberland and on the Scottish border; interspersed with brief notices of interesting events in border history. By Stephen Oliver, the younger [pseudon.]. London. I835. I $6^{\circ}$. Wdcts. and plan.

Imperfect: $-\mathrm{pp}$. i., ii. wanting.

Chapters I, 2, 4, 5, and 6 contain a few pages on fishing.

8436.14 Another copy.

*Ang. 39.24 [Chatto, William Andrew.] Scenes and recollections of fly-fishing in Northumberland, Cumberland, and Westmorland. By Stephen Oliver, the younger [psezdon.]. London. I834. I $6^{\circ}$. Wdcts.

Contains "The fishers' call" and "The angler's invitation," which were afterwards included in the "Newcastle fishers' garlands." - The appendix contains "Angling in the olden time," a review of the older angling literature; "Observations on the salmon tribe;" "Keswick and Ullswater compared;" "List of trout streams."

Cheap and good husbandry. 1676. $4^{\circ}$. See [Markham, Gervase].

Cheek, John. The British angler's instructor. I 862 . $24^{\circ}$. See Gould, Alfred.

Ang. 18.39.6 Cheek, John. J. Cheek, fishing rod and tackle, umbrella, parasol, walking stick and riding whip manufacturer, the Golden Perch. [Catalogue of prices.] London. I 839. $8^{\circ}$. pp. $25^{\circ}+$. Vign.

Ang. 18.39.6 [Cheek; John.] The young angler's guide; comprising instructions in the arts of fly-fishing, bottom-fishing, trolling, \&c. $2 \mathrm{~d}$ ed. London. I 839. $8^{\circ}$. pp. xvi. [xx.], 77. Plates and wdcts.

A tackle-maker's publication.

Ang. 16.81.3 [Chetham, James.] The angler's vade mecum; or, A compendious yet full discourse of angling. With a brief discourse of fish-ponds, and not only the easiest but most palatable ways of dressing of all sorts of fish, whether belonging to rivers or ponds; and the laws concerning angling, and the preservation of such fish. $3 \mathrm{~d}$ ed., much enlarged. London. 1700. I $6^{\circ}$. Plates.

Two editions were published in 1700 , the only difference between them being in the illustrations.

With the armorial book-plate of Peter Sarney Benwell. 
*Ang. I8.45.6 [Chitty, Edward.] The illustrated fly-fisher's text book; a complete guide to the science of fly-fishing for salmon, trout, grayling, \&c. By Theophilus South [pseudon.]. London. 1845. 8\%. Front., engr. title-page, 19 plates, and wdcts.

Imperfect:- plate "The grayling" wanting.

Ist edition, 184r, with the title "The fly-fisher's text-book." This is a re-issue, with additional plates.

Cholmondeley-Pennell, Henry. See Pennell, Henry. Cholmondeley.

Ang. 22.16 Chubb, Thomas H. Price list of hexagonal or six strip split bamboo, ash, and lance wood fishing rods, reels, lines, hooks, flies, etc., [sold by T. H. Chubb, manufacturer and importer of fishing tackle, Post Mills, Vt. Keene, N. H. I 886.] sm. $4^{\circ}$. pp. $55+$. Port. and wdcts.

Ang. 49.46.I I Clark, John. The salmon disease. Prize essay. London. I 884. $8^{\circ}$. pp. I I. (London, Eng.-International fisheries exhibition, I883. [The fisheries exhibition literature, xi. 4.])

Also another edition.

*Ang. I.39 [Clark, John Heaviside.] Field sports \&c. of the native inhabitants of New South Wales. London. I 8 I 3 . pp. (I8). Io plates. (Appended to HowitT, Samuel, and others. Foreign field sports, $1814,4^{\circ}$.)

The plates are by the author; two represent fishing scenes.

Ang. 18.39 [Clarke, Capt._- R. M.] The angler's desideratum; containing the best and fullest directions for dressing the artificial fly, with some new-and valuable inventions by the author, from a practice of nearly half a century. Edinburgh. I839. I $6^{\circ}$. pp. 48 . Wdcts.

IV. 2880 Clarke, Robert, \& co. A list of books on angling, hunting, shooting, and kindred subjects. Cincinnati, $O$. [i 888.] I $2^{\circ}$. pp. 32.

Ang. 47.2 I Clarke, Samuel C. The fishes of the east Florida coast; [with a chapter on "The fishing grounds of Florida, tackle and lures, by C. J. Kenworthy"]. Wdcts. (Appended to Van Doren, L. O. The fishes of the east Atlantic coast, I $884, \quad 8^{\circ}$, pp. 99-I 77.)

" Papers that have appeared in the American angler."

*Ang. 38. I [Clements, Lewis.] Shooting adventures, canine lore, and sea-fishing trips. By "Wildfowler," "Snapshot," of the Field. 2 vol. London. I879 [1878]. 8*. Wdcts.

"Sea-fishing trips," ii. 173-268. 
Ang. 38.2 [Clements, Lewis.] Shooting, yachting, and sea-fishing trips, at home and on the Continent. 2d series. By "Wildfowler," "Snapshot.". 2 vol. London. i877. $8^{\circ}$.

"Sea-fishing and seafowl-shooting excursions," ii. 75-3I3.

First appeared as articles in various sporting periodicals.

First series in 1876 , with the title, "Shooting and fishing trips in England, France, Alsace, Belgium, Holland, and Bavaria."

Clericus, pseudon. See Cartwright, William.

*Ang. 39.54 Cliffe, John Henry. Notes and recollections of an angler; rambles among the mountains, valleys, and solitudes of Wales. With sketches of some of the lakes, streams, mountains, and scenic attractions in both divisions of the principality. London, etc. I 860 . sm. $8^{\circ}$.

The author wishes "to afford the lovers of angling more minute particulars of some of the principal fishing stations than have hitherto ever been published."

*Ang. $39.55-$ The same. London. I870. sm. $8^{\circ}$.

A paginal reprint of the first edition.

Ang. 39.62 [Coad,'J.] The angling excursions of Gregory Greendrake [pseudon.] in the counties of Wicklow, Meath, Westmeath, Longford, and Cavan; with additions by Geoffrey Greydrake [pseudon. for Thomas Ettingsall].

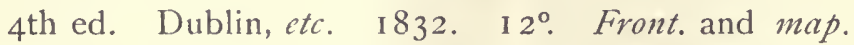

Originally published in parts: pt. I "Wicklow," 1824; pt. 2 "Westmeath," 1826. To this edition has been added pt. 3, "Meath, Longford, and Cavan; by Geoffrey Greydrake."

Ang. 49.46.6 Cobbold, Thomas Spencer. On the destruction of fish and other aquatic animals by internal parasites. London. I883. $8^{\circ}$. pp. 20. (LONDON, Eng.-International fisheries cxhibition, 1883. [The fisheries exhibition literature, vi. 7.])

Also another edition.

Cocheris, Hippolyte, editor. La vieille. I861. $8^{\circ}$. See Fournival, Richard DE.

Ang. 17.95 Cole, Ralph. The young angler's pocket companion; or, A new and complete treatise on the art of angling, as may be practised with success in every river in England. To which is now added, a new and most successful method of trolling and laying trimmers, with the best method of smelt-fishing. London. 1795. $24^{\circ}$. Front. and plates.

Ang. 17.95.3 The same. London. [1816.] $24^{\circ}$. Front. and wdcts.

With a monogram book-plate. - On the first fly-leaf is the autograph of "John Caley."

Some slight omissions have been made in this edition, but the part relating to smelt fishing appears, although no mention of it is made on the title-page. 
*Ang: 45.3r Collection (A) of right merrie garlands for north country anglers. Edited by Joseph Crawhall, and continued to this present year. Newcastle-on-Tyne. I 864. 8. Wdcts. and fac-sims.

Half-title:- " The Newcastle fishers' garlands."

A reprint of the celebrated "Fisher's garlands," I82I-45, with a continuation to 1864 . The authors of the later garlands are Roxby, Doubleday, Chatto, Crawhall, Thomas Westwood, Robert White, and "R. G.," probably Robert Gillan.

"Brief notices of some contributors to the original garlands," pp. 309-3I2.

I7466.12 Collection (A) of scarce, curious, and valuable pieces, both in verse and prose; chiefly selected from the fugitive productions of the most eminent wits of the present age. Edinburgh: W. Ruddiman. I773. I $2^{\circ}$.

"The art of angling; eight dialogues in verse," pp. 269-334.

Ang. 45.II The same. Edinburgh: T. Ruddiman and co. I 785 . I $2^{\circ}$.

With the exception of the title-page and preface, this is a paginal reprint of the earlier edition.

Ang. 39.47 Colquhoun, John. The moor and the loch; containing practical hints on most of the Highland sports, and notices of the habits of the different creatures of game and prey in the mountainous districts of Scotland. With an essay on loch-fishing. Edinburgh, etc. $1840.8^{\circ}$. Front., wdcts., and I I plates. $8 \mathrm{I}$.

"Loch-fishing," pp. 56-71; "Fishing on the salt-water lochs," pp. 72-

"Mr. Colquhoun's knowledge of sporting and fishing is superior to his attainments as a scientific naturalist. His chapters on salmon and trout fishing teem with useful hints, while he is indisputably the first authority of his time on the salmo ferox, and its capture in the larger Scotch lochs." - Westwood and Salchell.

Ang. $39.48-$ The same. 2 d ed. London. 1841. $8^{\circ}$. Front., redcts., and 14 plates.

Several new chapters have been added, including "The moor burn," pp. 138-149, and "River-angling," pp. 149-157.

Ang. 39.49 Colquhoun, John. The moor and the loch; containing minute instructions in all Highland sports, with wanderings over crag and correi, "flood and fell." $3 \mathrm{~d}$ ed. Edinburgh, etc. $185 \mathrm{I}$. $8^{\circ}$. Front., wdets., and 12 plates.

The author's "Rocks and rivers," which contains four chapters on fishing, has been incorporated with this edition.

*Ang. $39.50-$ The same. 5th ed., enlarged. 2 vol. Edinburgh, etc: I $880 . \quad$ sm. $8^{\circ}$. Portrs., wdcts., and 14 plates.

"Recollections of my early life," i. I-35. The author has added to the $4^{\text {th }}$ and $5^{\text {th }}$ editions, whatever passages in his other books "Salmon-casts and stray shots" and "Sporting days" appeared to be of interest, or calculated to assist the sportsman. 
Ang. 18.58.2 Colquhoun, John. Salmon-casts and stray shots; being fly-leaves from [his] note-book. 2d ed. Edinburgh, etc. 1858 . I $6^{\circ}$.

Portions of this work are included in the $4^{\text {th }}$ and $5^{\text {th }}$ editions of his "Moor and the loch."

Compleat and experienc'd angler (A). [cir. I7 I 2.] $24^{\circ}$. See [Markham, Gervase].

*Ang. 16.75.8 [Compleat servant-maid (The); or, The cook's guide. Containing directions for dressing all sorts of flesh, fowl, and fish. To which is added, recreation for the ladies by instructing them in the best methods of catching of fish, either in ponds or rivers. London? 169-?] $24^{\circ}$.

Imperfect: - title-page, pp. 53-58, and all of the "Table" except the first page, wanting.

This is an edition of "The accomplish'd lady's delight." The part entitled "The female angler" is compiled from Walton, Barker, and others. The title quoted is written in pencil on an inserted fly-leaf.

Compleatest angling booke (The) that ever was writ. [1881.] $4^{\circ}$. See [Crawhall, Joseph].

Ang. 60.4 Complete family-piece (The), and country gentleman and farmer's best guide; in three parts. I. Containing a choice collection of practical family-receipts in physick and surgery, cookery, pastry, and confectionary, etc. 2. Full instructions in hunting, coursing, and shooting; cautions, rules, and directions to be observed in fishing, with the manner of making and preserving rods, lines, artificial flies, \&c., and for chusing and preserving several sorts of curious baits; a kalender of all work to be done in gardens. 3. Rules for the improving of land, and managing a farm in all its branches. $2 \mathrm{~d}$ ed., improved. London. 1737. sm. I $2^{\circ}$.

"Directions for fishing," pp. 329-350.

Ang. 17.78.2 Complete fisherman (The); or, Universal angler. Containing full directions for taking all kinds of river fish; to which is added the whole art of fly-fishing, with instructions how to make artificial flies, likewise a compendious account of the principal sea-fish. $2 \mathrm{~d}$ ed. London. [1780?] I $2^{\circ}$. Front.

The frontispiece has the date 1778 .

A note in pencil on the first fly-leaf describes the work as "scarce \& curious."

Ang. 17.78.3 The same. 3d ed. London. [178-?] sm. I $2^{\circ}$. Front.

The frontispiece has the date 1778 . 
Ang. 60.3 Complete grazier (The); or, Gentleman and farmer's directory. Containing also directions for making fish ponds, or canals, and for storing them, and ordering the fish in the best manner. With several other useful and curious particulars. Written by a country gentleman, and originally designed for private use. 4 th ed. London. I 776 . I $2^{\circ} . W d c t$.

"Of fish ponds," pp. 244-252.

Ang. 50.15 Connecticut-Commissioners of fisheries. [Ist], 4thI $3^{\text {th, }}$ I $5^{\text {th }}-17^{\text {th, }}$ I th $^{\text {th }}-22 \mathrm{~d}$ report of the commissioners, I 867 , I 870-I 879, I 88 I-I 883, I 885-I 888. Hartford, etc. I $867-87.8^{\circ}$. Plates.

The Ist report has the title, "Report of the commissioners concerning the protection of fish in the Connecticut river, \&c." The r6th report is called " I6th annual report of the fish commissioners and Ist report of the shell fish commissioners." The pages containing the report of the shell fish commissioners have been taken out from this copy.

*Ang. 39.38 Conway, James. Forays among salmon and deer. London. I 86I. sm. $8^{\circ}$.

A reprint, with four additional chapters, of his "Letters from the Highlands."

9464.25 Conway, James. Letters from the Highlands; or, Two months among the salmon and the deer. London. 1859. sm. $8^{\circ}$. Front. and wdcts.

Several of the letters were originally published in the Field.

Reprinted, with additions, as "Forays among salmon and deer."

Cooper, Alfred W. Sporting sketches with pen and pencil. I878. $4^{\circ}$. See Francis, Francis, and Cooper, A. W.

Ang. 50.73 Cope, Edward Drinker. The fisheries of Pennsylvania. Plates. (Appended to Pennsylvania - Commissioners of fisheries. Report for I 881/82, $8^{\circ}$, pp. I03-194.)

"A descriptive and systematic account of the species of fishes known or supposed to exist in the waters of Pennsylvania."

Ang. 50.2.4( ( 7) Cope, Edward Drinker. On the zoölogical position of Texas. Washington. I880. $8^{\circ}$. pp. (4), 5 I. (U. S. NATIONal MUSEUM. Bulletin, i 7.)

VIII. 39(I 7) Another copy.

Coquet-dale fishing songs (The). 1852. $8^{\circ}$. See [Doubleday, Thomas].

Ang. 49.38 Cornish, James. A view of the present state of the salmon and Channel-fisheries, and of the statute laws by which they are regulated, showing that it is to the defects of the latter that the present scarcity of the fish is to be attributed. Comprehending also the natural history and habits of the salmon, with some of its peculiarities hitherto undescribed; with the form of a new act designed to 
remedy the evils so generally complained of, and an abstract of the evidence before the committee of the house of commons upon the subject. With notes. London. I $824.8^{\circ}$. Ang. 49.46.6 Cornish, Thomas. Crustaceans. London. 1883. $8^{\circ}$. pp. 21. (LONDON, Eng.-International fisheries exhibition, 1883. [The fisheries exhibition literature, vi. I I.]) Also another edition.

Ang. 49.46.6 Cornish, Thomas. Mackerel and pilchard fisheries. London. 1883. 8\%. pp. 38. (London. Eng.-International fisheries exhibition, I883. [The fisheries exhibition literature, vi. 4.])

Also another edition.

Ang. 48.12 Coste, Jean Jacques Marie Cyprien Victor. Instructions pratiques sur la pisciculture; suivies de mémoires et de rapports sur le même sujet. Paris. 1853. I $2^{\circ}$. Plates and wdct.

"Mémoire sur les bancs artificiels d'huitres du lac Fusaro," pp. I21-129; "Lettre de Jacobi sur la fécondation artificielle des oufs de saumon et de truite," pp. I30-I39.

*Ang. 48.8 Coste, Jean Jacques Marie Cyprien Victor. Practical instructions in fish-raising. (In FRY, W. H., editor. A complete treatise on artificial fish-breeding, I866, $12^{\circ}$, pp. 29-80.)

46.44 Coste, Jean Jacques Marie Cyprien Victor. Report on the means of stocking all the streams of France with fish. (In Garlick, Theodatus. A treatise on the artificial Ang. 48.1 propagation of certain kinds of fish, $1857,8^{\circ}$, pp. 55-67.) Ang. 48.2 Also in other editions.

See also W. H. Fry's "Complete treatise on artificial fish-breeding."

*Ang. 47.9 Couch, Jonathan. A history of the fishes of the British islands. Containing coloured plates from drawings by the author. 4 vol. London. I 868, '67-69. $8^{\circ}$. Wdcts. and $252 \mathrm{col}$. platcs.

Plates $1,58,121$, and 180 are used as frontispieces.

"This valuable work of a distinguished naturalist contains much information respecting the fisheries, and more especially those of Cornwall and Devon." - Westrwood and Satchell.

Osmund Lambert in his "Angling literature in England" says, "With the assistance of the illustrations contained in 'Couch' any of our fishes may be identified at a glance."

Ang. 60.2 Country gentleman's companion (The). By a country gentleman, from his own experience. 2 vol. London.

I 753 . Sm. I $2^{\circ}$.

"Of fishing," i. 235-239; "Of angling," ii. 64-106.

The treatise on angling in vol. ii. is the prose version of John Dennys's "Secrets of angling," published by Gervase Markham in his "Pleasures of princes" and "Country contentments." 
Country house-wife's garden (The). I676. $4^{\circ}$. See [Markham, Gervase].

Ang. 18.78.3 [Cox, Irwin Edward Bainbridge.] The angler's diary Ang. 18.78.4 and fisherman's guide to the rivers and lakes of the world. To which are added a list of rivers of Great Britain, with their stations; also forms for registering the fish taken during the year. By I. E. B. C. London. sm. $8^{\circ}$. (2 cop.)

This annual was first published as "The angler's diary; or, Forms for registering the fish taken during the year."

*Ang. 18.66.8 [Cox, Irwin Edward Bainbridge.] Facts and useful hints relating to fishing and shooting; being a collection of various methods for capturing birds, beasts, vermin, and fish, with recipes useful to the fisherman and sportsman. To which is added a list of recipes for the management and cure of dogs in disease. $3 \mathrm{~d}$ ed. Edited by I. E. B. C. London. 1874. sm. $8^{\circ}$. Wdcts.

*Ang. 16.74.3 [Cox, Nicholas.] The gentleman's recreation, in four parts, viz. hunting, hawking, fowling, fishing; wherein these exercises are largely treated of. With an abstract at the end of each subject of such laws as relate to the same. $3 \mathrm{~d}$ ed., with the addition of a Hunting-horse. London. 1686. sm. $8^{\circ}$. Front. and 3 plates.

The large folding plate which forms the frontispiece is entitled "The antient hunting noats with Marsh's additions." It is often wanting.

The "Hunting-horse" is apparently by another author, and has the imprint, Oxford, I685.

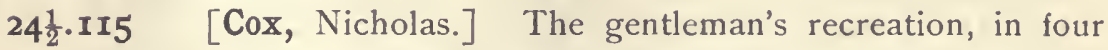
parts, viz. hunting, hawking, fowling, fishing; wherein these exercises are largely treated of. Also the method of breeding and managing a hunting-horse. 4th ed., to which is now added a perfect abstract of all the forest-laws, and of every particular act of parliament as do any way relate to the several kinds of game above mention'd. London. I697. sm. 8. Engr. title-page and. 4 plates.

*34.53 [- $]$ The same. Whereto is added a perfect abstract of all the forest-laws, with several forms of warrants relating thereto, never before printed. 6th ed., with large additions. London. 1721. sm. $8^{\circ}$. Front. and 4 plates.

Copies of these editions are seldom found complete.

The large folding plate here has the title "The antient hunting notes with Marsh's \& Coll, Cook's additions," and its illustrations are different from those of the one in the previous editions.

With the armorial book-plate of "Hen'ry Frankland Esqr" (Sir Charles Henry Frankland, Bart.) collector of the port of Boston, 1741-1757; and the autograph note "The gift of Henry Frankland Esqr to $\mathrm{H}=\mathrm{C}=$ Library - " 
*Ang. 16.74.6 Another copy.

Imperfect :- frontispiece, and pp. 5-8 of the "Forest laws," wanting.

Ang. 45.13 Crawhall, Joseph. Border notes \& mixty-maxty. [Newcastle upon Tyne.] I880. sm. $4^{\circ}$. Illustr. Lithographed.

" 50 copies. Imprinted by Andrew Reid for the author. Plates destroyed."

"An 'ollapodrida' of angling verse and miscellaneous drollery, illustrated with masterly pen and ink sketches, some of them by the author's son, coloured plates, head and tail pieces, elc." - Westwood and Satchell.

Crawhall, Joseph, editor. A collection of right merrie garlands for north country anglers. See Collection (A) of right merrie garlands, etc. I $864.8^{\circ}$.

*Ang. I.36 [Crawhall, Joseph.] The compleatest angling booke that ever was writ; being done oute of $y^{\mathbf{e}}$. Hebrewe and other tongues by a person of honor. [2d ed. Newcastleupon-Tyne. I $88 \mathrm{I}.] \quad 4^{\circ}$. Illustr.

Printed on one side of the leaf only. - 100 copies printed, and the plates destroyed.

Ist edition, 1859, limited to 40 copies. The illustrations are by the author, and consist of etchings, woodcuts, designs colored by hand, etc. The second edition contains nearly all the plates of the first, and almost as many new ones.

"A very curious and original work and one of the chief rarities of the angling bibliophile's collection. . . . It is partly historical and practical, partly legendary and poetical. . . . Some of the engravings were employed to adorn the large paper copies of the 'Newcastle fishers' garlands, ' 1864."

- Westrood and Salchell.

[Crawhall, Joseph, editor.] Izaak Walton: his wallet booke. I $885 . \quad 8^{\circ}$. See Walton, Izaak.

*Ang. 45.I4 Crawhall, Joseph. A jubilee thought, imagined \& adorn'd by Joseph Crawhall. Newcastle-on-Tyne. 1887. sm. $4^{\circ}$. pp. 75 . Illustr.

"A miscellaneous collection of scraps, concise poems, and historical reminiscences, chiefly of Newcastle, with very odd block illustrations." - Publishers' ircular.

One of the illustrations represents a fish.

Ang. 18.80 Cross, David W. Fifty years with the gun and rod. Including tables showing the velocity, distance, penetration or effect of shot, calculated by Leonard Case; gun trials by the Chicago Field; how and where to "hold," etc. Cleveland, Ohio. I $880 . \quad 8^{\circ}$. Wdcts.

Ang. 18.23 [Cussac, J.] Pisciceptologie; ou, L'art de la pêche à la ligne. Discours sur les poissons, la manière de les prendre et de les accommoder; la pêche aux filets et autres instrumens; suivi d'un traité des étangs, etc. [Also "table raisonnée des pêches, avec les noms des poissons

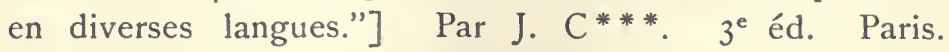
I $823 . \mathrm{sm} .12^{\circ}$. Front. and 28 plates. 
Ang. 18.63 Cutcliffe, H. C. The art of trout fishing on rapid Ang.18.63.2 streams; comprising a complete system of fishing the north Devon streams and their like. With detailed instructions in the art of fishing with the artificial fly, the natural fly, the fern web, beetle, maggot, worm, and minnow, both natural and artificial. South Molton. 1863 . $16^{\circ}$. (2 cop.)

Ang. I8.63.3 The same. London. I883. I $6^{\circ}$.

*Ang. 47.4 Cuvier, Georges, Baron. The class pisces; with supplementary additions by Edward Griffith and C. H. Smith. London. 1834. 1. $8^{\circ}$. pp. viii., 680. Front. and 63 plates.

Forms vol. x. of his "Animal kingdom," ${ }_{1827-35}$

With the armorial book-plate of Samuel T. Tisdale.

Cypress, J., jr., pseudon. See Hawes, William Post.

D., J. The secrets of angling. I 8 I I, etc. See [Dennys, John].

Ang. I8.or Daniel, William Barker. Rural sports. 3 vol. London. I 807. 1. $8^{\circ}$. Plates, plan, and tables.

The title-pages are engraved.

Vol. ii. is devoted to angling.

This edition contains the plates of the first edition (1801-2), with additional ones. Most of them were engraved by John Scott, who excelled all his predecessors in the art of engraving animals. Lowndes' "Bibliographer's manual," Westwood and Satchell's "Bibliotheca, piscatoria," and other bibliographies, do not mention an edition of 1807 .

Ang. I8.0I — Supplement. [London.] I8I3. 1. 8\%. pp. (10), 742, (29). Port. and plates.

The title-page is engraved.

Pages $1-571$ are devoted to angling, and contain Sir Henry Ellis's "Catalogue of books on angling," a translation of book xv. of Vanit re's "Prædium rusticum," an account of the rivers of Great Britain, elc.

Danish parsonage (A). I884. $8^{\circ}$. See [Vicary, J. F.].

*Ang. 26.4 Dashwood, Richard Lewes. Chiploquorgan; or, Life by the camp fire in Dominion of Canada and Newfoundland. New ed. London. I872. sm. $8^{\circ}$. Front. and plate.

rst edition, $18 j i$.

Contains accounts of fishing in the Nepisiguit, Restigouche, and other rivers.

Ang. 18.76 Davies, George Christopher. Angling idylls. London. I $876 . \mathrm{sm} .8^{\circ}$.

A part of this work is included in Chatto's "Angler's souvenir," edited by Davies, which appeared in 1877 . 
Ang. 18.73.4 Davies, George Christopher. Fishing; a comprehensive handbook of the art, including sea-fishing. London. [1873?] I 6\%. pp. 64. Wdcts.

This edition was published by Dean and son. An edition was published by the "graphotyping company" in 1873 , as one of the series called "Champion handbooks."

*Ang. 18.73.3 Davies, George Christopher. Mountain, meadow, \& mere. A series of outdoor sketches of sport, scenery, adventures, and natural history. 2d ed. London. 1874. sm. $8^{\circ}$. Front., plates, and wdcts.

Many of the articles originally appeared in the Field, and other periodicals. There are several chapters on fishing.

*Ang. 39.3 Davies, George Christopher. Norfolk broads and rivers; or, The water-ways, lagoons, and decoys of east Anglia. Edinburgh, etc. I883. $8^{\circ}$. Front. and II plates.

Most of the chapters originally appeared in periodicals.

"The illustrations are printed on copperplates direct from negatives taken, with one exception, by the author, and etched by a process worked by Messrs. T. \& R. Annan."

Contains "The fish of the broads;" "The herring-fishery;" "About eels;" "Eel-sets;" "Pike-fishing in Jordan;" and other chapters on fishing.

\section{II Another copy.}

Ang. 44.I3 Davies, George Christopher. Peter Penniless, gamekeeper and gentleman. With original illustrations. London. [r884.] sm. $8^{\circ}$. Front. and wdcts.

Contains several chapters on fishing.

*Ang. 18.28 [Davy, Sir Humphry, bart.] Salmonia: or, Days of fly fishing; in a series of conversations. With some account of the habits of fishes belonging to the genus salmo. By an angler. London. 1828 . I $6^{\circ}$. Plates and wdcts.

"Illustrations from the author's own drawings." - Westrood and Satchell. - A review of this work, attributed to Sir Walter Scott, is found in the Quarterly reviezw, vol. xxxviii., 1828, pp. 503-535.

Ang. 18.28.2 [-] The same. $2 \mathrm{~d}$ ed. London. I829. I $6^{\circ}$. Plates and wdcts.

Contains six additional engraved plates.

34. I66 Another copy.

*Ang. 18.28.3 [- $[-]$ The same. Ist American from 2d London ed. Philadelphia. 1832. sm. $12^{\circ}$. Plates.

Does not contain the six engraved plates.

*Ang. 18.28.4 [- $]$ The same. $3 \mathrm{~d}$ ed. London. I832. $16^{\circ}$. Plates and wdcts.

Has the same illustrations as the second edition.

Ang. 18.28.6 - The same. 4th ed. London. 1851. 16\%. Portrs, and wdcts.

This edition contains additions by Dr. John Davy, brother of the author. 
Ang. 18.28.5 [Davy, Sir Humphry, bart.] Salmonia: or, Days of fly-fishing; in a series of conversations. With some account of the habits of fishes belonging to the genus salmo. - Consolation in travel, or, The last days of a philosopher. London. I 840.1 . $12^{\circ}$. Plates.

This is vol. ix. of his "Collected works," $1839-40$, without the general title-page and " advertisement."

*Ang. 18.55.2 Davy, John ( I790-1 868). The angler and his friend; or, Piscatory colloquies and fishing excursions. London. I 855. I $6^{\circ}$. Wdcts.

*Ang. 18.57.13 Davy, John (1790-1868). The angler in the Lake District; or, Piscatory colloquies and fishing excursions in Westmoreland and Cumberland. London. I $857.16^{\circ}$.

Ang. 18.83.3 Dawson, George (1813-1883). Angling talks; being the "Winter talks on summer pastimes" contributed to the Forest and stream. New York. I $883 . \quad$ sm. $8^{\circ}$. pp. 78.

The "Talks" were published in $1882-83$.

*Ang. 18.76.5 Dawson, George (1813-1883). Pleasures of angling with rod and reel for trout and salmon. New York. 1876. sm. $8^{\circ}$. Front. and plates.

"Most of the sketches which make up this volume were published in the Albany evening journal." They contain accounts of fishing excursions to the Cascapedia, a little river in the province of Quebec, and of trout fishing in the Adirondacks.

Ang. 38.9 Dax, Louis, vicomte DE. Souvenirs de mes chasses et pêches dans le midi de la France; suivis de renseignements sur la chasse à tir en France. Paris. I 858 . I $8^{\circ}$.

Half-title:- "Récits de sport."

*Ang. 47.II Day, Francis. British and Irish salmonidæ. London, etc. I $887.1 .8^{\circ}$. Wdcts. and 12 plates.

All but three of the plates are colored. The illustrations were drawn by the author, and colored from nature by Miss Florence Woolward.

Ang. 49.46.8 Day, Francis. The commercial sea fishes of Great Britain. Prize essay. London. I 884. $8^{\circ}$. (LONDON, Eng. - International fisheries exhibition, 1883. [The fisheries exhibition literature, viii. I.])

Also another edition.

Ang. 49.46.2 Day, Francis. Fish culture. London. I883. $8^{\circ}$. 4 plates. (LONDON, Eng. - International fisheries exhibition, 1883. [The fisheries exhibition literature, ii. I.]) Also another edition.

Ang. 47.47 Day, Francis. On the fishes of the Andaman islands. [London. 1870.] $8^{\circ}$. pp. (29).

Proceedings of the zoollogical society, 1870, pp. 677-705. 
*Ang. I.20 Day, Francis. The fishes of Malabar. London. I865. $4^{\circ}$. Wdcts. and 20 plates.

The plates were drawn and engraved by the author.

47.16 Another copy.

Ang. 47.47 Day, Francis. On the fishes of the Neilgherry hills and rivers around their .bases. [London. I 867.] $8^{\circ}$. pp. (22).

Proceedings of the zoölogical society, 1867, pp. 28I-302.

Ang. 49.46.6 Day, Francis. On the food of fishes. London. 1883. 8. pp. 36. (LONDON, Eng.-International fisheries exhibition, I883. [The fisheries exhibition literature, vi. 8.])

Also another edition.

Ang. 49.46.2 Day, Francis. Indian fish and fishing. London. 1883. $8^{\circ}$. pp. (2), $59+$. Wdcts. and 4 plates. (LoNDON, Eng. - International fisheries exhibition, i 883. [The fisheries exhibition literature, ii. 6.])

Also another edition.

Ang. 47.47 Day, Francis. Remarks on some of the fishes in the Calcutta museum. - On the freshwater fishes of Burma, pt. i. [London. I 869.] $8^{\circ}$. pp. (43).

Proceedings of the zoölogical society, 1869, pp. 511-527, 548-560, 611-623.

Ang. 49.3 Day, Francis. Report on the fresh water fish and fisheries of India and Burma. [With appendices.] Calcutta. 1873. $8^{\circ}$.

VIII. 39I (ix) De Caux, J. W. The best system of life insurance for fishermen. (In LONDON, Eng. - International fisheries exhibition, I 883. The fisheries exhibition literature, I 884 , $8^{\circ}$, ix. I I 5-137.)

Ang. I.25 De Kay, James Ellsworth. . Zoölogy of New-York; or, The New-York fauna. Comprising detailed descriptions of all the animals hitherto observed within the state, with brief notices of those occasionally found near its borders. Pt. iii., iv. 2 pt. in I vol. Albany. I 842, and atlas of IO2 plates. (In NEW YORK (State) - Geological survey. Natural history of New York, I $842,4^{\circ}$, i. 3, 4.)

Contents:- - iii. Reptiles and amphibia. - iv. Fishes.

"List of works referred to," iii. v.-vi.; iv. xi.-xii.

The general title-pages are engraved.

With the armorial book-plate of John C. Brune.

Ang. 18.68.2 Dempster, Henry. The decked-welled fishing boat, and fisheries and fish market reform; being dialogues on these important subjects. With full information on the oyster question. Glasgow. I 868. I $6^{\circ}$. Plates and zodcts. 
*Ang. 45. I5 [Dennys, John.] The secrets of angling; teaching the choicest tooles, baits, and seasons for the taking of any fish in pond or river. Practised, and familiarly opened in three books, by J. D. Augmented with many approved experiments, by W. Lauson. [Edited by Sir Henry Ellis.] London. 1652. Reprinted I81 I. $8^{\circ}$. pp. (8), $36+$. Wdcts.

With the armorial book-plate of John Caley(?) whose autograph appears on the first fly-leaf.

100 copies printed. - Ist edition, 1613 . This reprint was published in I8 12 , in Brydges' "British bibliographer," ii. 465-502. Lauson's additions contain the seven woodcuts of hooks.

"Beloe says of the book that 'perhaps there does not exist in the circle of English literature a rarer volume.' Sir John Hawkins confessed 'he could never get a sight of it." "- Westwood aind Satchell.

"No more musical and graceful verses were ever written on the art of angling."-Dict. nat. biog.

For an account of the author and the work, see Westwood and Satchell's "Bibliotheca piscatoria," pp. 73-75; also, Osmund Lambert's "Angling literature in England," pp. 43-46.

Ang. 45.17 [-] The same. By I. D. London. I6I3. [With the comments of William Lauson, I653.] Wdcts. (Reprinted in ARBER, Edward, editor. An English garner, I $877,8^{\circ}$, i. 141-I98.)

"A very imperfect version."-Dict. nat. biog.

I5427.27(i) Another copy.

Ang. 45.16 The same. 1613. A reprint, with introduction by Thomas Westwood. London. I883. sm. $4^{\circ}$. pp. 62 .

I4453.46 Another copy.

I4453.47 [- ] The same. Edited [with notes] by "Piscator." 2 vol. in I. "Edinburgh. I885. 16\%. (BIBLIOTHECA curiosa, 43.)

350 copies. - " Privately printed."

"List of books relating to angling," ii. 63-64.

Ang. 18.78.2 [Desloges, Louis Camille Auguste.] Le parfait pêcheur à la ligne, au filet, etc.; suivi du calendrier du pêcheur, d'un traité de pisciculture simplifié, de l'aquarium, et des lois et ordonnances sur la pêche fluviale. Par L. B. Renauld [pseudon.]. Paris. I878. I $6^{\circ}$. Wdcts.

Ist edition, I858, signed " Renaud;" later editions were signed " L. D. Renauld."

*Ang. 24.I D'Ewes, J. Sporting in both hemispheres. London, etc. $1858.5 \mathrm{sm} .8^{\circ}$. Col. front. and col. plates.

Chapters 15,16 , and 19 are on fishing.

"The author is said to be a descendant of Charles Cotton."-Westrwood and Salchell.

AL I152.2.2 I Dexter, Charles. Angling songs. (In his Versions and verses, I $865,8^{\circ}$, pp. I $35^{-1}$ 54.) 
Ang. 18.35.10 Deyeux, Théophile. Le vieux chasseur. $5^{\mathrm{e}}$ éd., revue par son fils, précédée d'une préface par Jules Janin. Paris. I $873.24^{\circ}$. Wdcts.

Ist edition, 1835 .

Page 177 contains " Tir du poisson dans l'eau." This is the only mention of fishes that occurs.

*Ang. 18.73 Dick, St. John. Flies and fly-fishing for white and brown trout, grayling, and coarse fish; with hints on using the minnow and grasshopper bait. London. I873. $\mathrm{sm} .8^{\circ}$. Wdcts.

Dinks, pseudon. See Peel, Jonathan.

Discourse (A) of fish and fish-ponds. I7I3, etc. See [North, Roger].

Ang. 45.30 [Doubleday, Thomas.] The Coquet-dale fishing songs. Now first collected and edited by a north-country angler. Edinburgh, etc. I 852 . sm. $8^{\circ}$.

Consists of the original contributions of Doubleday and Robert Roxby to the "Newcastle fishers' garlands," with the history of the composition of each song, and a short sketch of Roxby's life. The airs to which the songs were composed are appended.

Doubleday, Thomas. The fisher's garland for 1821 , etc. See Fisher's garland (The). 1821 , etc. $8^{\circ}$. Note.

Ang. 18.4I Dougall, James Dalziel. Salmon and trout angling. 2 d ed. Glasgow, etc. I 843 . I $6^{\circ}$. pp. 48. Firont.

This is the first edution, 184I, with a new title-page.

*Ang. 18.62.5 Dryden, Adam. Hints to anglers. Edinburgh. I 862. $24^{\circ}$. pp. (4), 40. 5 maps.

The last half of the book describes the trout streams of the south of Scotland.

Du Bartas, Guillaume de Saluste, seigneur. See Saluste, Guillaume DE, scigneur Du Bartas.

Ang. 48.34 Dubravius, Joannes, bp. of Olmutz. De piscinis libri v. Accedunt ejusdem argumenti ex veterum recentiorumque scriptorum libris excerpta. Omnia Herm. Conringii curā iterum edita, \& ab innumeris mendis purgata, cum præfationibus. Helmestadii. I67 I. sm. $4^{\circ}$. Wdct.

The extracts are from Varro, Columella, Pliny, Constantinus Porphyrogenetus, Crescenzi, and Heresbach.

A translation was published in I599, with the title, "A new booke of good husbindry, very pleasaunt, and of great profite both for gentlemen and yomen, etc."

Ang. 49.46.6 Duff, Robert William. The herring fisheries of Scotland. London. 1883. $8^{\circ}$. pp. 40. (London, Eng. International fisheries exhibition, 1883 . [The fisheries exhibition literature, vi. 3.])

Also another edition. 
*Ang. I.2 Duhamel du Monceau, Henri Louis. Traité général des pesches, et histoire des poissons qu'elles fournissent, tant pour la subsistance des hommes que pour plusieurs autres usages qui ont rapport aux arts et au commerce. Par M. Duhamel du Monceau et M. de La Marre. [Tom. i.]; - Par M. Duhamel du Monceau. [Tom. ii.]iv. 4 tom. in 3. Paris. 1769-82. fo. Plates, maps, and diagrs.

"One of the finest works on fishing and the fisheries in any language. The plates number 250." - Westwood and Satchell.

Included in the "Description des arts et métiers faite ou approuvée par MM. de l'académie des sciences."

Ang. 44.16 Dykes, Thomas. All round sport with fish, fur, \& feather; also adventures on the turf and the road, in the hunting and cricket fields, and over yachting courses, links, and curling ponds. With illustrations by Finch Mason, A. E. Havell, R. M. Alexander, F. C. Boult, and Cuthbert Bradley. London. I $887.8^{\circ} 0^{\circ}$ Wdcts. and 24 plates.

"A series of stories, sketches, and songs. . . . Some have already seen the light in various journals." - Preface.

"With the rod on Loch Lomond," pp. 6I-65; " The pick o' the basket, [poem]," p. I73; "How we opened Loch Ard," pp. 2II-2I5; "With the long-line fishers on the east coast," pp. 232-242; "Salmon-fishing on Loch Tay," pp. 275-279.

*Ang. 45.19 Edinburgh angling club. Songs of the club. With illustrations drawn and engraved by members of the club. New ed., with additions. Edinburgh. 1879. 80. Front., engr. tille-page, vigns., and fac-sim.

Ist edition, $185 \mathrm{I}$.

"Printed privately for members of the club."

The illustrations are engraved by William Forrest, from drawings by George Simson, R. Caunter, W. Forrest, A. Perigal, and others. The engraved title-page has the date 1878 .

Edinburgh, Scotland - International fisheries exhibition, I882. Fish and fisheries; a selection from the prize essays of the exhibition. I883. $8^{\circ}$. See Herbert, David, editor.

46.44 Edwards, Henri Milne. Report on artificial fish-culture, and on stocking barren and impoverished rivers with fish artificially hatched. (In GARLICK, Theodatus. A treatise on the artificial propagation of certain kinds of fish, I 857 ,

Ang. 48.1 $8^{\circ}$, pp. 35-54.)

Ang. 48.2 Also in other editions.

See also W. H. Fry's " Complete treatise on artificial fish-breeding." 
Ang. 44.I8 Ellacombe, Henry Nicholson. Shakespeare as an angler. London. 1883. $\sin .8^{\circ}$. pp. 78 . Front.

"A reprint of two papers written for the Antiquary, in October and November, 188r. . . The frontispiece, representing an angler of the time of Shakespeare, is taken from the 'Song of the nightingale,' in the Roxburghe ballads, vol. ii. p. 253, ed. Chappell."- Preface.

An appendix contains four old poems on angling, and a list of sea-fish mentioned by Shakespeare.

VII. 1625 Elliott, Henry Wood. The seal-islands of Alaska. Maps, plates, and wdcts. (In GoodE, G. B. The history and present condition of the fishery industries, $\mathrm{I} 88 \mathrm{I}, 4^{\circ}, \mathrm{ix}$.)

"Catalogue of the fishes of the Pribylov group," pp. 136-137.

Ang. I.44 _ The same, separated.

V. I204 A monograph of the seal-islands of Alaska. Washington. 1882. $4^{\circ}$. Plates, maps, and wdcts. (U.S. commission of fish and fisheries. Special bulletin, I76.)

"Reprinted, with additions, from the report on the fishery industries of the Ioth census."

${ }^{*} 20.6-$ Report on the seal islands of Alaska. Maps, VI. 284I plates, and wdcts. (In United States-Census. (I880.) The newspaper and periodical press, etc., I 884, $4^{\circ}$, [3].) 2 cop.

VII. I680

Also in the set of Congressional Documents.

I2353.30 Elliott, William ( I788-1863). Carolina sports by land and water; including incidents of devil-fishing, \&c. Charleston. I 846 . I $2^{\circ}$.

Contains "Devil fishing;" "Drum fishing;" "Bass fishing;" "Sheepshead fishing."

"Several of the sketches have already been published under the signatures of 'Piscator' and 'Venator.' ",

Ang. 30.I 5 plates. The same. New York. $1859.12^{\circ}$. Front. and A chapter on the sea-serpent has been added.

Ang. 30.2 The same. London. I867. sm. $8^{\circ}$.

Ang. 3.I

[Ellis, Sir Henry ( I 777-1 869).] A catalogue of books on angling; with some brief notices of several of their authors. London. I8I I. $8^{\circ}$. pp. (2), 2 I .

First published in the "British bibliographer," vol. ii., 1812. "Not more than sixty detached copies with title-page and index were taken off," is noted by Sir Henry, in a revised copy with Ms. additions. This is the earliest attempt at a list of books on angling, and registers 75 distinct works in chronological order. It was reprinted without acknowledgment, in the supplement to Daniel's "Rural sports," I8r 3 ; and again, enlarged and improved, by Pickering in 1836 , with the title "Bibliotheca piscatoria," as a supplement to Boosey's "Piscatorial reminiscences."

Ephemera, pseudon. See Fitzgibbon, Edward.

Epitome (The) of the art of husbandry. 1669. $24^{\circ}$. See [Blagrave, Joseph]. 
*Ang. 46.22 [Esdaile, David.] Contributions to natural history, chiefly in relation to the food of the people. By a rural D.D. 2d ed. Edinburgh, etc. $1867.16^{\circ}$. Widts.

Contents:- Hippophagy; or, Should we eat our horses? - The progress of hippophagy; a plea for eating horse-flesh. - Mycophagy; or, Should we eat funguses? - Life and history of a salmon. - Salmon and pisciculture. Scotch salmon and Scotch law. - The salmon rivers of England and Wales.Salmon, British and colonial. - Salmon-rearing at Stormontfield, and fish culture. - Something more about the hatching of fish. - The herring. - Popular weather prognostics. - Hirudiculture (leech-culture). - Maritime pisciculture :- Lagoon of Comacchio. Oyster-culture. Mussel-culture. - Fish diet, and its effects on the human constitution. - Fish-culture at Fusaro and Concarneau.- Horses, ancient and modern. - The Arab horse of Africa. Acclimatisation societies. - New system of sea-fishing.

Ang. 49.18 Essay (An) on the right of angling in the river Thames, and in all other public navigable rivers; in which the public right to angle in all such rivers is stated and proved. Reading. [1787?] $3^{\circ}$. pp. (10), 61.

Written in answer to a pamphlet published in 1787 , entitled " A letter to a proprietor of a fishery on the river Thames."

[Ettingsall, Thomas.] The angling excursions of Gregory Greendrake, with additions by Geoffrey Greydrake. 1832. I 2\%. See [Coad, J.].

Ang. 18.20 Evans, W. The art of angling; or, Complete fly-fisher: describing the different kinds of fish, their haunts, places of feeding, \&c. To which are added the various kinds of baits, and diversity of flies which nature produces, with directions for making artificial flies. New ed., revised and corrected. London. [182-?] I $2^{\circ}$.

This is the edition published in Uxbridge in 1820 , with a new title-page.

With a few slight changes it is the same as the earlier editions of Charles Bowlker's " Art of angling."

Exact and authentic account (An) of the greatest whiteherring-fishery in Scotland. I885. 8\%. Sec Campbell, John.

F., K. J. By the loch \& river side. I 866. obl. $4^{\circ}$. See [Finlay, K. J.].

Ang. 49.2 Faber, George Louis. The fisheries of the Adriatic and the fish thereof. A report of the Austro-Hungarian seafisheries, with a detailed description of the marine fauna of the Adriatic gulf. [With an introduction by Albert Günther.] London. I883. $4^{\circ}$. Front., plates, plans, and tables.

"Bibliography," pp, xxv.-xxvi.

"Index to the Italian local and vulgar names of the Adriatic fauna," pp. 268-276. - "Index to the Croatian local and vulgar names," pp. 277283.

18 of the illustrations are after drawings by Leo Littrow. 
Facts on the natural history and habits of the salmon. [I 867.] 8. See [Garnett, Thomas].

Ang. 17.60.2 Fairfax, Thomas, Esq. The complete sportsman; or, Country gentleman's recreation. Containing the art of angling in all its various branches, the breeding and managing game cocks, etc. By J. [or rather T.] Fairfax. New ed., revised, corrected, and improved. London. I 795. sm. I $2^{\circ}$.

Ist edition, about 1760 .

"Angling," pp. I-44.

Ang. 17.60.3 [Fairfax, Thomas, Esq.] The new Complete sportsman; or, The town and country gentleman's recreation. Containing the whole arts of angling, the breeding and managing game cocks, etc. Revised, corrected, and improved by George Morgan, assisted by many experienced gentlemen. London. [I8-?] I $2^{\circ}$.

Imperfect: - frontispiece wanting.

"Angling," pp. I-44.

The text is identical with that of the edition of 1795 .

Familiar history (A) of the British fishes. [I 859.] I $6^{\circ}$. See [Buckland, F. T.].

*Ang. 28.3 Farrar, Charles Alden John. Eastward, ho! or, Adventures at Rangeley lakes. Containing the amusing experience and startling incidents connected with a trip of a party of Boston boys to the wilds of Maine. A story founded on fact. Boston, etc. I880. sm. I $2^{\circ}$. Front., zedcts., and map. (In his Lake and forest series.)

Describes several fishing excursions.

Ang. 28.7 Farrar, Charles Alden John. Illustrated guide book to the Androscoggin lakes, and the head-waters of the Connecticut, Magalloway, and Androscoggin rivers, Dixville notch, Grafton notch, and Andover, Maine, and vicinity. Also a treatise on camping out, the game and fish laws of Maine and New Hampshire, railroad, steamboat, and stage routes, etc. [I Ith ed.] Boston, etc. I 887. sm. $8^{\circ}$. Map and wdcts.

Gives information about the fishing in these regions.

10317.5 Farrar, Charles Alden John. Illustrated guide book to Moosehead lake and vicinity, the wilds of northern Maine, and the head-waters of the Kennebec, Penobscot, and St. John rivers. Also the game and fish laws of Maine, railroad, steamboat, and stage routes, etc. Boston, etc. $\quad$ I 878 . I 6. Front., map, and zudcts.

Imperfect:- large map wanting. 
10317.6 Farrar, Charles Alden John. Illustrated guide book to Moosehead lake and vicinity, etc. [3d ed.] Boston, etc. I880. 1 $6^{\circ}$. Front., map, and wdcts.

Imperfect:- - large map wanting.

Ang. 28.8 The same. [7th ed.] Boston, etc. I884. I $2^{\circ}$. Front., wdcts., plate, and maps.

*Ang. 49.24 [Fea, James.] An account of the new method of fishing on the coasts of Shetland. Published in 1775 . (Appended to his Present state of the Orkney islands considered, $1884,8^{\circ}$, pp. 1 31-160.)

With a reprint of the original title-page.

*Ang. 49.24 [Fea, James.] The present state of the Orkney islands considered; and, An account of the new method of fishing on the coasts of Shetland. Published in 1775 . Edinburgh. I $884 . \mathrm{sm} .8^{\circ}$.

" 162 copies printed. No. $26 . "$

With reprints of the original title-pages.

*Ang. 18.70.2 Fennell, (John) Greville. The book of the roach. London. $1870.16^{\circ}$.

Field sports \&c. of the native inhabitants of New South Wales. 1813. $4^{\circ}$. See [Clark, J. H.].

*Ang. I.34 [Finlay, K. J.] By the loch \& river side. [A series of 39 humorous etchings on stone, depicting the pleasures and perils of an angler's life; by K. J. F.] Edinburgh. 1866. obl. $4^{\circ}$.

The title-page also contains an etching.

Ang. 18.80.5 Fish, and how to catch them. By an experienced angler. Bury St. Edmund's. [i 880.$]$ I $6^{\circ}$. pp. 39. Wdct.

Fisher boy (The). [I808.] $16^{\circ}$. See [Ireland, S. W. H.].

Ang. 44.22 Fisher, James, of Annan, Scotland. A spring-day; or, Contemplations on several occurrences which naturally strike the eye in that delightful season. 2d ed., carefully corrected and improved. Edinburgh. 1806. $8^{\circ}$. Vigns.

Ist edition, 1803 .

"On fishing," pp. 245-275.

Ang. I8.8I.2 Fisher, John, angler. La pêche à toutes lignes; théorique, pratique, et raisonnée, déduite de la connaissance de l'histoire naturelle, des mœurs et habitudes des poissons d'eau douce. Ouvrage comprenant la législation spéciale et les principes d'art culinaire. Paris. I88I. $12^{\circ}$. Wdcts. and 4 plates.

Fisher, P., pseudon. See Chatto, William Andrew. 
*Ang. 18.64.2 Fisherman's magazine and review (The). Edited by H. Cholmondeley-Pennell. Vol. i., ii. April, 1864-Oct. I 865. $m .2$ vol. London. I864-65. $8^{\circ}$. Fronts., plates, and wodcts.

No more published.

Most of the plates are lithographs of fishes, and many of them are colored.

This publication contains contributions by the editor, Heseltine, Westwood, and others. Several of the papers are reprinted in the editor's "Fishing gossip."

Fishermen's own book (The). [cop. 1882.] $8^{\circ}$. See [Procter, G. H., compiler].

Ang. 45.20 Fisher's garland (The), for I 82I-I 845. 28 vol. Newcastle. I 821 ['23]-45. sm. $8^{\circ}$. Vigns.

Nos. i.-xxvi. were published by Emerson Charnley, the others by William Garret.

Commonly known as the "Newcastle fishers" garlands." They appeared later under the title, "A collection of right merrie garlands for north country anglers." An edition with this title, edited by Joseph Crawhall in 1864, contains 21 additional garlands. Sixteen of the original garlands appear in the "Coquet-dale fishing songs," I 852, and nos. i. and ii. are found in Pearson's " Angler's garland," I870-7I.

Each title-page contains a woodcut, most of them from blocks by Thomas Bewick. With a few exceptions, however, the blocks have been so thoroughly changed that it is difficult to recognize them.

Nos. ii., iv., v., vii., viii., xiv., signed R. R., were written by Robert Roxby and Thomas Doubleday; iii., vi., xiii., xvi., xx.-xxii., signed W. G. T., by W. G. Thompson; ix., signed W. G., by William Greene; x.-xii., xxiii.xxix. (all but x. and xi. signed R. R.) by Thomas Doubleday; xv., signed R. N., by Robert Nichol, remodelled by W. G. Thompson; xvii.-xix., signed W. A. C., by W. A. Chatto.

The title "Fisher's garland" does not appear on nos. vi. and xxviii.

The number of copies of the Garlands printed varied from 196 (iv.) to 400 (viii.), being commonly under 300 , and may be found, with other details, in Westwood and Satchell, pp. 1 57-160.

Contents:-[i.] See [BoAz, Herman]. The angler's progress. 1820.

[ii.] The fisher's garland. I821 [1823].

[iii.] Tyne side. I 822 [ 1824$]$.

[iv.] Coquet side. 1823 .

[v.] The auld fishers' welcome to Coquet-side. 1824 .

[vi.] The Tyne fisher's farewell to his favourite stream on the approach of winter. I 824 [1825].

[vii.] The auld fisher's fareweel to Coquet. 1825 .

[viii.] "The Coquet for ever." I 826.

[ix.] The fisher's call. I 827 .

[x.] The fisher's call. 1828 [ 1829 ].

[xi.] The old fisher's challenge. 1829 .

[xii.] The old angler's triumph. 1830.

[xiii.] The Tyne fisher's call. I831.

[xiv.] The fisher's invitation to his friend in Newcastle. 1832.

[xv.] The angler's delight. I833 [ 1842 ].

[xvi.] The morning invitation. 1834 [1842].

[xvii.] My Glendale friend, Will Reedy O! An angler's greeting. 1835 [ 1842$]$.

[xviii.] The angler's invitation. I836 [1842]. 
[xix.] The fishers' call. 1837 [1842].

[xx.] Summer rambles; or, The fisher's delight. I 838 [1842].

[xxi.] The auld fisher's invitation to supper. 1839 [1842].

[xxii.] A day by the side of the fast-flowing Tyne. 1840 [1842].

[xxiii.] The auld fisher's last wish. I841.

[xxiv.] Auld and young. I842.

[xxv.] The angler's adieu for the season. 1842. Autumn number.

[xxvi.] "Up the Wreigh." 1843 .

[xxvii.] The fisher's courtship. 1844 .

[xxviii.] The auld fisher's invitation to his friend in Newcastle to gang wi' him to north Tyne to take anither thraw. 1844 .

[xxix.] The morning airly. 1845 .

Ang. 18.62.3 Fishing; when, where, and how to fish without live bait. London. I 862 . sq. $16^{\circ}$. pp. 32. Wdcts.

Imperfect:- pp. 1, 2, wanting.

"Written in easy style for boys."

Ang. I.I8 Fishing gazette (The); devoted to angling, river, lake, and sea fishing, and fish culture. [Edited by R. B. Marston.] Vol. vi.-xi.; xii. no. $457-460,470$; xiii. 480. July 8 , I 882 - July 3 , I 886 . w. London. I882-86. fo. Wdcts. and portrs.

The set is very imperfect:- it contains only 34 numbers of vol. vii. and less than half of vi., viii.-x., xi.

*Ang. 18.50.2 [Fitzgibbon, Edward.] The book of the salmon; in two parts. I. The theory, principles, and practice of flyfishing for salmon, with lists of salmon-flies. 2. The natural history of the salmon, and the best way of artificially breeding it explained. By Ephemera, assisted by Andrew Young. London. $185^{\circ}$. $16^{\circ}$. Front. and 8 plates.

The frontispiece and all the plates but one are colored.

The second part is substantially the work of Andrew Young, who was the manager of the duke of Sutherland's salmon-fisheries, and a great authority on the subject.

Osmund Lambert in his "Angling literature in England," says, "Unfortunately it is more than difficult to obtain a copy of Ephemera's 'Book of the salmon." "'

*Ang. 18.47.3 [Fitzgibbon, Edward.] A handbook of angling: teaching fly-fishing, trolling, bottom-fishing, and salmonfishing; with the natural history of river fish, and the best modes of catching them. By Ephemera. 2d ed., improved and extended. London. I848. I $6^{\circ}$. Wdcts.

Ist edition, 1847 .

"Perhaps the very best of the enormous number of manuals on fishing which are extant." - Dict. nat. biog.

*Ang. 18.47.4 [- The same. 3d ed., corrected and improved. London. 1853. $16^{\circ}$. Front. and wdcts.

*Ang. 18.47.5 [- The same. 4th ed. London. I865. I $6^{\circ}$. Front. and wdcts. 
*Ang. 48.8 [Fitzgibbon, Edward.] Lessons on the natural history and habits of the salmon; [by] Ephemera. (In FRY, W. H., editor. A complete treatise on artificial fish-breeding, I $866, \mathrm{I}^{\circ}$, pp. I $11-178$.)

*44454.10 [Fletcher, Phineas.] Piscatorie eclogs, and other poeticall miscellanies. By P. F. Cambridge [Eng.]. 1633. (Appended to his Purple island, 1633, $4^{\circ}$.)

Ang. 45.33 The same. With notes, critical and explanatory [by A. F. Tytler, Lord Woodhouselee]. Edinburgh, etc. I 77 I. sm. $8^{\circ}$. Vign.

The "poetical miscellanies" in this edition consist of only three poems, while the previous edition has thirty-four.

*Ang. 18.5I Fly-fishing in salt and fresh water. London. I85I. 8. pp. viii., 74. Wdct. and 6 plates.

Five of the plates are colored.

*Ang. 18.87.3 Fly. maker's hand-book (The); illustrated with coloured plates representing upwards of fifty of the most useful artificial flies for trout and grayling fishing. By an angler. Liverpool. [1887.] sq. $24^{\circ}$. pp. $45.9 \mathrm{col}$. plates and wdct.

Ang. 50.33 Forbes, Stephen Alfred. A catalogue of the native fishes of Illinois. Plates. (Appended to IllinoIs - Fish commission. Report, I $884,8^{\circ}$, pp. 60-89.) Also in the report of 1886.

4.ri6 Ford, Simon. Piscatio. (In Musarum anglicanarum analecta, r699, $8^{\circ}$, i. I 29-1 43.)

4.13I Also in the edition of I721.

Ang. 45.34 Ford, Simon. Piscatio, or, Angling; a poem, written originally in Latin. Translated from the Muse anglicane by Tipping Silvester. Oxford. 1733. sm. $8^{\circ}$. pp. (4), 23. Also in Silvester's "Original poems and translations," I733.

"More an adaptation than a translation." - Westwood and Satchell.

*Ang. 18.8I Ford, Thomas, of Caistor, Eng. Trotıt-fishing. Londen. [r88I.] sm. $8^{\circ}$. pp. 64 .

The author is a tackle-maker.

Foreign field sports. I8I4. $4^{\circ}$. See Howitt, Samuel, and others.

Ang. 38.25 Forester, Thomas. Norway in 1848 and 1849 ; containing rambles among the fjelds and fjords of the central and western districts, and including remarks on its political, military, ecclesiastical, and social organisation. With extracts from the journals of M. S. Biddulph. London. 1850. $8^{\circ}$. Front., map, wedcts., and 9 plates.

Contains a short account of the fisheries of Bergen, and occasional references to angling.

The illustrations are from sketches made during the rambles by Lieut. Biddulph, and the map has been constructed from his personal observations. 
Forrester, Frank, pseudon. See Herbert, Henry William.

*Ang. 1.47 [Fortin, François.] Les ruses innocentes; dans lesquelles se voit comment on prend les oyseaux passagers, \& les non passagers, \& de plusieurs sortes de bestes à quatre pieds. Avec les plus beaux secrets de la pesche dans les rivières $\&$ dans les estangs, et la manière de faire tous les rets \& filets qu' on peut s'imaginer. Ouvrage très curieux, utile, \& récréatif pour toutes personnes qui font leur séjour à la campagne. Par F. F. F. R. D. G. dit le Solitaire inventif. Paris. I660. $4^{\circ} .66$ plates.

The present " edition has become very rare, and is, on the whole, the most interesting contribution made by France to the literature of angling." - Westwood and Satchell.

This was the forerunner of a series of works with the same or similar titles, by various compilers. Louis Liger's "Amusemens de la campagne" was founded upon it, and in several editions the first book of "Les ruses" appears without alteration, and with reduced copies of the illustrations.

The initials used by the author in the title are interpreted: Frère François Fortin religieux de Grandmont.

*Ang. 18.82 Foster, David. The scientific angler; being a general and instructive work on artistic angling. By David Foster; compiled by his sons. London, etc. [1882.] sm. $8^{\circ}$. Port. and 6 plates.

"Sketch of David Foster," pp. vii.-x.

Ang. 18.82.2 — The same. Edited by W. C. Harris. New York. I883. I $2^{\circ}$. 6 plates.

This edition does not contain the chapter on trout culture, as the editor considers it "far behind the present advanced status of fish culture in America."

*Ang. 45.35 Foster, W. A. Songs on angling, etc. New York. I $886.8^{\circ}$. pp. 20.

" 25 copies privately reprinted from 'Whistle-Binkie' and the 'Book of Scottish song.',"

Ang. 45.36 Fournival or FURNIVAL, Richard DE. La vieille; ou, Les dernières amours d'Ovide; poëme français du XIVe siècle, traduit du latin par Jean Lefèvre. Publié pour la première fois et précédé de recherches sur l'auteur du Vetula par Hippolyte Cocheris. Paris. I 86I. sm. $8^{\circ}$.

" 350 exemplaires."

"Translated, or rather imitated, from a Latin poem De vetulā, attributed to Richard de Fournival. . . . The passage which treats of fishing is headed 'Comment Ovide tendait aux poissons,' and consists of 68 lines. De Fournival's work cannot but be interesting to the angling bibliophile, as showing that more than 400 years ago most of the modern modes of fishing were practised. . . The poem was formerly attributed to Ovid, and a story was current that a copy had been discovered in his tomb. It was first printed, probably at Rome, about $\mathbf{1 4 7 0}$, under the title: 'P. Ovidii Nasionis liber de vetula." "- Westwood and Satchell. 
*Ang. 18.77 Francis, Francis (1822-1886). Angling. London. $1877.8^{\circ} .4$ plates.

This is a less extensive work than his "Book on angling," and was written for those who desired a cheaper publication.

Ang. 1.53 Francis, Francis (1822-1 886). Angling. [New York? 1878?] $4^{\circ}$. pp. (I3). Wdcts.

"From the Encyclopadia britannica, 9th ed.," ii. 32-44.

*Ang. 18.87.2 Francis, Francis (1822-1886). Angling reminiscences. . London. I 887 . sm. $8^{\circ}$.

*Ang. 18.67.3 Francis, Francis (1822-1886). A book on angling; being a complete treatise on the art of angling in every branch. London. $1867.5 \mathrm{sm} .8^{\circ}$. Front. and 14 plates.

Five of the plates are colored.

Osmund Lambert in his "Angling literature in England" says of this work, "No book so well answers the angler's purpose."

*Ang. 18.67.5 - The same. 3d ed., revised and improved. London. 1872 . sm. $8^{\circ}$. Front. and 16 plates.

A new frontispiece containing likenesses of the author and his gillie, and a new colored plate of salmon flies have been added. A few changes have also been made in the other plates, and the work has been somewhat enlarged.

*Ang. 18.67.6 - The same. 4th ed., revised and improved. London. $1876.5 \mathrm{sm} .8^{\circ}$. Front. and 16 plates.

This edition contains between thirty and forty pages of fresh matter. Plate I has been entirely recast; the other illustrations are the same as those of the preceding edition.

*Ang. 39.5 Francis, Francis (1822-1886). By lake and river; an angler's rambles in the north of England and Scotland. London. I874. $\mathrm{sm} .8^{\circ}$.

Includes many articles originally published in the Field.

*Ang. 48.5 Francis, Francis (1822-1886). Fish-culture; a practical guide to the modern system of breeding and rearing fish. London, etc. $1863 . \mathrm{sm} .8^{\circ}$. Front. and wdcts.

"Our sea fisheries," pp. 178-227.

*Ang. 48.6 The same. $2 \mathrm{~d}$ ed., revised and enlarged. London, etc. $1865 . \quad \mathrm{sm} .8^{\circ}$. Front. and wdcts.

*Ang. 44.24 Francis, Francis (1822-1886). Newton Dogvane; a story of English country life. With illustrations by Leech. 3 vol. London. I859. sm. $8^{\circ}$. Fronts.

Chapters 2, 3, and Io of vol. i., and chapter 5 of vol. iii. contain accounts of fishing excursions.

*Ang. 48.6.2 Francis, Francis (1822-1886). The practical management of fisheries. A book for proprietors and keepers. London. 1883. sm. $8^{\circ}$. $W d c t s$, plans, and plates. 
"Ang. 44.25 Francis, Francis (1822-1886). Sidney Bellew; ' a story. 2 vol. London. 1870 . sm. $8^{\circ}$.

Many of the chapters were originally published in Baily's magazine, r8606r, with the title, "The experiences of Sydney Godolphin Yahoo, Esq."

Chapters 5, I0, I2, 13 of vol. i. and chapter 6 of vol. ii. describe fishing excursions.

Ang. I.48 Francis, Francis (1822-1886), and Cooper, Alfred W. Sporting sketches with pen and pencil. London. 1878. $4^{\circ}$. Vigns. and 12 plates.

Contents:- The first of September. - A day in a punt. - Mark cock! Trouting. - Long tails and short ones. - Paying the pike. - Rabbit shooting. - Roaching. - Grouse shooting. - Salmon fishing. - Snipe shooting. Grayling fishing.

The text is by Francis, and the illustrations are by Cooper. "His drawings are most of them sketches from nature, and many of the figures are portraits of well-known persons," including Alfred Jardine, Mr. Aldam, and the authors themselves.

*Ang. 32.3 Francis, Francis, $j r$. Saddle and mocassin. London. I $887.8^{\circ}$.

Among these sketches of travel in America, the author has inserted a chapter entitled "The Winchester water meads," which describes a day's fishing in England with his father, the author of "A book on angling," and other angling works.

Ang. 3.4 Francis, Henry Ralph. The fly-fisher and his library. (In CAmbridge [Eng.] essays, 1856, 8º pp. 233-260.)

9.20 Another copy.

*Ang. 39.43 Franck, Richard. Northern memoirs calculated for the meridian of Scotland, wherein most or all of the cities, sea-ports, rivers, and rivulets are described; with choice collections of various discoveries, remarkable observations, etc. To which is added, the contemplative \& practical angler, by way of diversion; with a narrative of that dextrous and mysterious art experimented in England, and perfected in more remote and solitary parts of Scotland. By way of dialogue. Writ in the year 1658 , but not till now made publick. London. 1694 . $16^{\circ}$.

"As a specimen of style this book is sui generis. . . . Franck is the first English writer on angling who describes that mystical fish, the burbolt. . . There is also an interesting mention of three noted anglers of the time, Merrils, Fawlkner, and Owldham, whom some bibliophiles suppose to have written three several angling works, since lost to the world. . . . A notice of the work will be found in the Retrospective revierw, vol. viii. pp. I70I94, and also in the 'Censura literaria.' The extreme rarity of the original edition is somewhat exaggerated. We have had knowledge of five or six copies." - Westruood and Satchell.

"Franck is the first to describe salmon-fishing in Scotland, and both in that and trout-fishing with artificial fly, he proves himself an excellent practical angler. His rules for fly-fishing and especially for salmon-fishing, cannot be improved at present." - Dict. nat. biog. 
Ang. 39.44 Franck, Richard. Northern memoirs, calculated for the *Ang.39.45 meridian of Scotland; to which is added, the contemplative and practical angler. Writ in the year 1658 . New ed., with preface and notes [by Sir Walter Scott]. Edinburgh, etc. I821. $8^{\circ}$. (2 cop.)

250 copies printed.

Aftcr referring to the author's disparagement of Walton, and expressing a wish that Walton had made this tour instead of Franck, the editor says: "Yet we must do our author the justice to state that he is as much superior to the excellent patriarch, Isaac Walton, in the mystery of fly-fishing, as inferior to him in taste, feeling, and common sense."

*Ang. 47.40 Fraser, Alexander, of Dochnalurg. Natural history of the salmon, herrings, cod, ling, \&c.; with a short account of Greenland, its inhabitants, land and sea animals, and the different tribes of fishes found on the coast. $2 \mathrm{~d}$ ed. Inverness. I 833. I $2^{\circ}$.

Ang. I.40 Fraser, Robert. A review of the domestic fisheries of Great Britain and Ireland. [With an appendix.] Edinburgh, etc. I8 I8. $4^{\circ}$. Map.

\section{Ang. I.4I Another copy.}

The title-page has the author's autograph.

Fresh woods and pastures new. 1887. $8^{\circ}$. See [Marston, Edward].

*Ang. 48.8 Fry, William Henry, editor. A complete treatise on artificial fish-breeding. Including the reports on the subject made to the French academy and the French government, and particulars of the discovery as pursued in England. New York. I 866 [cop. I 854]. I $2^{\circ}$. Wdcts.

Conlents:- Treatise on the artificial fecundation and incubation of the eggs of fish; prepared from the facts furnished by M. Gehin to C. E. P. Godenier. - Practical instructions in fish-raising; by M. Coste. - Report on artificial fish-culture, and on stocking barren or impoverished rivers with fish, artificially hatched; by M. Milne Edwards. - Report on the means of stocking all the streams of France with fish; by M. Coste.-Lessons on the natural history and habits of the salmon; by Ephemera [Edward Fitzgibbon]. - On the breeding and preservation of salmon; by Salmo.

Ang. 49.46.4 Fryer, Charles E. A national fisheries society. Read at a conference of the international fisheries exhibition, July 26th, I 883. London. I883. $8^{\circ}$. pp. 49. (London, Eng.-International fisheries exhibition, 1883. [The fisheries exhibition literature, iv. 6.])

Also another edition.

Ang. 49.46.9 Fryer, Charles E. The relations of the state with fishermen and fisheries, including all matters dealing with their protection and regulation. Prize essay. London. 1884 . 8. pp. 86. (LONDON, Eng. - International fisheries exhibition, I 883. [The fisheries exhibition, literature, ix. 3.])

Also another edition. 
Ang. 49.46.2 Fryer, Charles E. The salmon fisheries. London. I 883. $\quad 8^{\circ}$. pp. vi., 77. Front., wdcts., and plans. (LoNDON, Eng. - International fisheries exhibition, 1883 . [The fisheries exhibition literature, ii. 4.])

Also another edition.

Fur, fin, and feather. I871, etc. $8^{\circ}$. See Brown, M. B., \& co., publishers.

G., F. F. F. R. D. Les ruses innocentes. I660. $4^{\circ}$. See [Fortin, François].

Gamekeeper (The) at home. I880. $8^{\circ}$. See [Jefferies, Richard].

Ang. 49.46.7 García Solá, Francisco. The basis for legislation on fishery questions. London. I 883. $8^{\circ}$. pp. 19. (LoNDON, Eng.-International fisheries exhibition, 1883. [The fisheries exhibition literature, vii. 9.])

Also another edition.

VIII. 39I(v) García Solá, Francisco. The fisheries of Spain. (In London, Eng.-International fisheries exhibition, I883. The fisheries exhibition literature, $1884,8^{\circ}$, v. 353-363.)

46.44 Garlick, Theodatus. A treatise on the artificial propagation of certain kinds of fish, with the description and habits of such kinds as are the most suitable for pisciculture. Giving the author's first experiments contained in a paper read before the Cleveland academy of natural science; also directions for the most successful modes of angling for such kinds of fish as are herein described. Cleveland. I $857.8^{\circ}$. Wdcts.

Consists of articles originally published in the Ohio farmer.

"Report on artificial fish-culture," by H. M. Edwards, pp. 35-54.

"Report on the means of stocking all the streams of France with fish," by J. J. M. C. V. Coste, pp. 55-67.

"Dr. Garlick is regarded as the father of fish-culture in America." - Westwood and Satchell.

Ang. 48.I The same. New York. I858 [cop. I856]. $8^{\circ}$. Wdcts.

The Ist edition with a new title-page.

Ang. 48.2 The same. 2d ed., enlarged. Cleveland, O. I $880.8^{\circ} . W d c t s$.

Ang. 50.50 Garman, Samuel. The American salmon and trout, including introduced species. 19 plates. (Appended to MASSAÇHUSETTS - Commissioners of fisheries. I9th annual report for $1884,8^{\circ}$, pp. 61-8I.) 
Ang. 48.21 [Garnett, Thomas (1799-1878).] Facts on the natural history and habits of the salmon, and some opinions on the laws affecting them, with suggestions for their improvement. Clitheroe. [i 867.] $8^{\circ}$. pp. 59.

"Printed for private distribution."

Consists of letters written at different times from 1834-1866, some of which were published in Loudon's Magazine of natural history, and in various newspapers.

*Ang. 45.38 Gay, John. Rural sports; a georgic in two cantos. Ang. 45.39 Cambridge. I 880. sm. $4^{\circ}$. pp. 27. (2 cop.)

" 25 copies printed for John Bartlett. No. I; No. 4."

The greater part of the first canto is devoted to angling.

Ang. 17.26 Gentleman angler (The). Containing short, plain, and easy instructions, whereby the most ignorant beginner may, in a little time, become a perfect artist in angling. With an appendix, containing the method of rock and sea-fishing, etc. By a gentleman who has made angling his diversion upwards of twenty-eight years. London. 1726. sm. $12^{\circ}$.

Ang. 17.26.2 The same. To which is added a treatise concerning Thames fishing. $2 \mathrm{~d}$ ed., with large additions. London. I $736.5 \mathrm{sm}$. I $2^{\circ}$.

*Ang. 17.26.3 — The same. 3d ed., with large additions. London. N. D. $\mathrm{sm}$. I $2^{\circ}$.

This is the edition of 1736 with a new title-page. Bartlett's Catalogue gives the date as I753, but Westwood and Satchell give, besides the 1753 edition, a " 3 d edition" without date.

*Ang. 17.26.5 — The same. By a gentleman who has made it his diversion upwards of fourteen years. London. I 786. sm. I $2^{\circ}$. Front.

This edition does not contain the "Treatise concerning Thames fishing," which appears in the two previous editions; the "Angler's song," the "Laws of angling," and a part of the appendix are also omitted.

Ang. 17.26.6 [Gentleman angler (The).] The angler's guide; containing easy instructions for the youthful beginner, with several observations on fishing, pointing out the proper times and seasons for the different kinds of fish. To which is added an appendix. By a lover of the art. London. 1828. $24^{\circ}$.

Imperfect: - frontispiece wanting.

The original title of the work was "The gentleman angler."

Gentleman fisher (The). 1727. $8^{\circ}$. See [Whole art of fishing (The)].

Gentleman's recreation (The). 1686, etc. $8^{\circ}$. See [Cox, Nicholas]. 
Ang. 50.2.4(I I) Gill, Theodore. Bibliography of the fishes of the Ang. 3.II Pacific coast of the United States, to the end of 1879. Washington. 1882. $8^{\circ}$. pp. (4), 73. (U. S. NATIONAL MUSEUM. Bulletin, II.) 2 cop.

VIII. 39(I I) Another copy.

I22.24 The same. Washington. I882. pp. (2), 73. (In Smithsonian miscel. coll., I 882, $8^{\circ}$, xxiii. I.)

45.4I(I3) Gill, Theodore. Catalogue of the fishes of the eastern coast of North America, from Greenland to Georgia. Jan. I861. [Philadelphia. I861.] $8^{\circ}$. pp. 63.

Issued with the Proceedings of the academy of natural sciences of Philadel. phia, 186r.

122.23 The same. Washington. I 873. pp. (4), 50. (In Smithsonian miscel. coll., I $878,8^{\circ}$, xiv. 2.)

" Bibliography," pp. 37-44.

" May be considered as a new edition, as it covers the same ground, but, as it has been entirely recast . . . it is essentially a new work."

Ang. $47 \cdot 47$ The same, separated.

Ang. 50.2 The same. (Appended to United States-Commission of fish and fisheries. Report for $187 \mathrm{I} / 72,8^{\circ}$, pp. 779-822.)

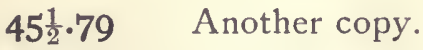

*Ang. 25.2 [Gillmore, Parker.] Accessible field sports; the experiences of a sportsman in North America. By Ubique. London. $1869 . \mathrm{sm} .8^{\circ}$. Front. and wdct.

Contains "Trout fishing on the Androscogan;" "Salmon fishing in Labrador;" " Trout fishing in Maine;" " The split bamboo fly-rods."

Ang. 18.69 [Gillmore, Parker.] Gun, rod, and saddle. Personal experiences. By Ubique. New York. 1869. I $2^{\circ}$. Front. and vign.

Consists of articles which originally appeared in Land and water, an English periodical. There are several chapters on fishing.

*Ang. 25.3 Gillmore, Parker. Prairie and forest; a description of the game of North America, with personal adventures in their pursuit. New York. 1874. $12^{\circ}$. Front. and wdcts.

Contains "Salmonidæ;" "Striped, black, and common bass;" "Muskallonge."

Ang. 47.47 Girard, Charles. Characteristics of some cartilaginous fishes of the Pacific coast of North America. - Abstract of a report to J. M. Gilliss, upon the fishes collected during the U.S. N. astronomical expedition to Chili. [Philadelphia. I 854.] 8. pp. (4).

"From the Proceedings of the academy of natural sciences, Nov. 1854." 
Ang. 47.47 Girard, Charles. Descriptions of new fishes collected by A. L. Heermann. - Enumeration of the species of marine fishes collected at San Francisco, California, by C. B. R. Kennerly. - Observations upon a collection of fishes made on the Pacific coast of the United States by W. P. Trowbridge. [Philadelphia. I 854.] $8^{\circ}$. pp. (28).

"From the Proceedings of academy of natural sciences, Aug. I854."

Pam. Another copy.

Ang. 47.47 Girard, Charles. Notice of a new species of salmonidæ from the north-eastern part of the United States; [salmo gloverii. Philadelphia. I 854.] $8^{\circ}$. I page.

" From the Proceedings of the academy of natural sciences, May, 1854 ."

Ang. 47.47 Notice upon the species of the genus salmo, of authors, observed chiefly in Oregon and California. [Philadelphia. I 856.] $8^{\circ}$. pp. (4).

" From the Proceedings of the academy of natural sciences, Oct. 1856 ."

Ang. 47.47 Girard, Charles. Notice upon the viviparous fishes inhabiting the Pacific coast of North America, with an enumeration of the species observed. [Philadelphia. I 855.] 8. pp. (6).

" From the Proceedings of the academy of natural sciences, April, I855."

Pam. Another copy.

Ang. 18.60 Glenfin, pseudon. The fishing-rod and how to use it; a treatise on the various arts of angling, trolling, spinning, and fly-fishing. London. I $860.16^{\circ}$. pp. viii., 87.

Ang. 18.60.2 - The same. London. 1861. 16\% pp. viii., 87.

The I 860 edition with a new title-page.

Ang. 29.9 Gloucester fox hunting club. Memoirs of the Gloucester fox hunting club, near Philadelphia. Philadelphia. 1830. $8^{\circ}$. pp. (2), 56 +. Front. and port. of Fonas Cattell.

I2384.65 Another copy.

I2384.65.2 The same. (Appended to Schuylkill FISHING company, Philadelphia, Penn. A history of the Schuylkill fishing company, $1889,8^{\circ}$, pp. 405-429.)

*Ang. 48.8 Godenier, C. E. P. Treatise on the artificial fecundation and incubation of the eggs of fish, and the rearing of the young fish, according to the processes of Messrs. Gehin and Remy. (In FRY, W. H., editor. A complete treatise on artificial fish-breeding, I866, $12^{\circ}$, pp. 7-28.) 
Ang. 47.14 Goode, George Brown. American fishes; a popular treatise upon the game and food fishes of North America, with especial reference to habits and methods of capture. New-York: $W$. A. Houghton. i 888. $8^{\circ}$. Col. front., wdcts., and plates.

"Prepared for the use of the angler, the lover of nature, and the general reader. It is not intended for naturalists." - Prologue.

V. 286I The same. New-York: Standard book co. I 888. 8. Col. front., wdcts., and plates.

Goode, George Brown. Catalogue of the collection to illustrate the animal resources and the fisheries of the United States. I879. 8०. See Philadelphia, Penn.International exhibition, I 876.

Ang. 50.2.4(5) Goode, George Brown. Catalogue of the fishes of the Bermudas. Based chiefly upon the collections of the United States national museum. Washington. I876. $8^{\circ}$. pp. (2), 82. (U. S. National museum Bulletin, 5.)

VIII. 39(5) Another copy.

122.23 The same. Washington. 1876. pp. 82. (In Smithsonian miscel. coll., i $878,8^{\circ}$, xiii. 5.)

Ang. 46.27 Goode, George Brown. Classification of the collection to illustrate the animal resources of the United States. A list of substances derived from the animal kingdom, with synopsis of the useful and injurious animals, and a classification of the methods of capture and utilization. Washington. I876. $8^{\circ}$. (Internat. exhib., 1876. Board on behalf of U. S. executive departments.)

Pam. Another copy.

VIII. 39(6) - The same. Washington. I876. (In U. S. NATIONAL MUSEUm. Bulletin, $1876,8^{\circ}, 6$.)

122.23 The same. Washington. 1876. (In SмIтHsONIAN miscel. coll., I $878,8^{\circ}$, xiii. 6.$)$

Goode, George Brown. Exhibit of the fisheries and fish culture of the United States of America, at the internationale fischerei-ausstellung, Berlin, I880. I880. $8^{\circ}$. See Berlin, Germ. - Internationale fischerei-ausstellung, 1880.

Ang. 50.2 Goode, George Brown. The natural and economical history of the American menhaden. [With "Menhaden and other fish and their products as related to agriculture, by W. O. Atwater," and appendices.] Plates, maps, and plan. (Appended to UnITED STATES - Commission of fish and fisheries. Report for $\left.1877,8^{\circ}, \mathrm{pp} . \mathrm{I}-529.\right)$

" Bibliography of literature relating to the menhaden," pp. 274-279. 
Ang. 47.47 Goode, George Brown. A preliminary catalogue of the reptiles, fishes, and leptocardians of the Bermudas, with descriptions of four species of fishes believed to be new. New Haven. I877. $8^{\circ}$. pp. (12).

"From the American journal of science and arts, vol. xiv., Oct. 1877," pp. 289-298.

Ang. 49.46.5 Goode, George Brown. A review of the fishery industries of the United States, and the work of the U. S. fish commission. Read at a conference of the international fisheries exhibition, June 25,1883 . London. $1883.8^{\circ}$. pp. 84. Tables. (LoNDON, Eng.-International fisheries exhibition, 1883 . [The fisheries exhibition literature, v. I.])

Also another edition.

Ang. 47.47 Goode, George Brown, and Bean, Tarleton Hoffman. A list of the fishes of Essex county, including those of Massachusetts bay, according to the latest results of the work of the U. S. fish commission. Salem. I879. $8^{\circ}$. pp. (2), 38 .

"From the Bulletin of the Essex institute, vol. xı."

VI. 2553 Goode, George Brown, and others. The fisheries and fishery industries of the United States. Prepared through the co-operation of the commissioner of fisheries and the superintendent of the roth census. Sect. i.-v. Washington. 1884-87. $4^{\circ}$. Plates, charts, wdcts., and atlas of 547 plates, 2 vol.

Contents:-i. Natural history of useful aquatic animals. I884, and atlas of 277 [292] plates. - ii. A geographical review of the fisheries industries and fishing communities for 1880. I887. - iii. The fishing grounds of North America; edited by Richard Rathbun. 1887. - iv. The fishermen of the United States; by G. B. Goode and J. W. Collins. I887. - v. History and methods of the fisheries. 2 vol. 1887, and allas of 255 plates.

Ang. 50.23 Another copy of i., ii., and atlas.

Ang. 50.2 Goode, George Brown, and others. Materials for a history of the mackerel fishery; by G. B. Goode, J. W. Collins, R. E. Earll, and A. H. Clark. Chart. (Appended to United States - Commission of fish and fisheries. Report for I88I, $8^{\circ}$, pp. 9I-53I.)

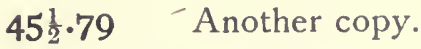

Ang. 18.95 Gore-Booth, Sir Henry William, 5th bart. Whaling. Plates and zudcts. (In Bickerdyke, John. Sea fishing, I $895,8^{\circ}$, pp. 469-497.) 
*Ang. 46.23 Gosse, Philip Henry. Life in its lower, intermediate, and higher forms; or, Manifestations of the divine wisdom in the natural history of animals. 2d ed. London. 1857. I $6^{\circ}$. Front., plates, and wdcts.

"The greatest part of the work was originally published in Excelsior."

46.59 Another copy.

Ang. 36.I Gosse, Philip Henry. A naturalist's sojourn in Jamaica; by P. H. Gosse, assisted by Richard Hill. London. I $85 \mathrm{I}$. $12^{\circ}$. Col. front. and $6 \mathrm{col}$. plates.

Imperfect: - plate 5 wanting.

Contains several chapters on fishes.

Ang. 47.3 Gouan, Antoine. Histoire des poissons; contenant la déscription anatomique de leurs parties externes \& internes, \& le caractère des divers genres rangés par classes \& par ordres. Avec un vocabulaire complet, des expériences sur le mouvement natatoire \& musculaire, sur le méchanisme de la respiration, sur les organes de l'ouie \& de la génération. Lat. and Fr. Strasbourg. 1770. "4\% 4 plates.

\subsection{Another copy.}

*Ang. 18.62.6 Gould, Alfred. The British angler's instructor; shewing the rods \& tackle necessary for every description of fish usually angled for, with the most approved methods of catching them. [To which is added a catalogue of prices of fishing-tackle, and the rules of cricket.] By Alfred Gould, late John Cheek, Golden Perch. [London.] 1862. $24^{\circ}$. pp. $94+$. Wdcts.

This is a trade publication, distributed gratuitously.

The earlier editions were published by John Cheek.

Gould, Augustus Addison. Report on the invertebrata of Massachusetts. I841, etc. $8^{\circ}$. See MassachusettsZoölogical and botanical survey.

Ang. 26.II Grand Trunk railway. Guide to the fishing and hunting resorts in the vicinity of the Grand Trunk railway of Canada. Containing particulars of fish, game, hotels, livery, and general facilities. Montreal. I 888 . sm. $8^{\circ}$. pp. 56. Vign.

The last page of the cover contains a map.

Ang. 44.31 Grant, Robert (b. 1852). Jack in the bush; or, A summer on a salmon river. Boston. $1888 . \mathrm{sm} .8^{\circ}$. Front. and wdcts.

*Ang. 49.3I Great fisheries of the world (The), described and illustrated. London, etc. [1878.] sm. $8^{\circ}$. Front., illustr. title-page, and wdcts.

Published in 1876 with the title, "The treasures of the deep." 
Ang. I.9 Great Britain - Commissioners to inquire into the salmon fisheries of England and Wales. Report of the commissioners, with the minutes of evidence. London. I86I. $f^{\circ}$.

Also in the series of Parliamentary papers for $\mathrm{r} 86 \mathrm{r}$, vol. xxiii.

Ang. I.I0 Great Britain-Inspectors of Irish fisheries. Report on the deep sea, coast, and inland fisheries of Ireland, for I872. Dublin. I873. fo.

Also, with the reports for other years, in the series of Parliamentary papers.

Ang. 49.4 Great Britain - Inspectors of salmon fisheries for England and Wales. I 2 th annual report. [By F. T. Buckland and Spencer Walpole.] London. I 873. $8^{\circ}$. Diagrs.

Also, with the reports for other years, in the series of Parliamentary papers.

Ang. I.II Great Britain - Select committee to consider the state of the salmon fisheries in Scotland. Report from the committee, with the minutes of evidence [and] appendix. [London. 1836.] fo. Plates and maps.

Also in the series of Parliamentary papers for 1836 , vol. xviii.

Ang. 49.46.II Green, H. J. The herring fisheries. Prize essay. London. I884. $8^{\circ}$. pp. I2. (LONDON, Eng.-International fisheries exhibition, 1883 . [The fisheries exhibition literature, xi. IO.])

Also another edition.

Ang. 48.7 Green, Seth. Home fishing and home waters; a practical treatise on fish culture, the utilization of farm streams, the management of fish in the artificial pond, the transportation of eggs and fry; with observations on common fish and the methods of capturing them. New York. I 888 . sm. $8^{\circ}$. pp. 8 r.

Ang. 48.30 Green, Seth. Trout culture. Published by Seth Green and A. S. Collins. Rochester, N. Y. I870. $8^{\circ}$. pp. $90+$. Port. and wdets.

The author was assisted in preparing the work by his partner, A. S. Collins.

In this copy another portrait of Green is pasted on the inside of the front cover.

VII. 267 Another copy.

Greendrake, Gregory, pseudon. See Coad, J.

Greene, William. The fisher's garland for i 827 . See Fisher's garland (The). I821, etc. $8^{\circ}$. Note.

*Ang. 18.60.3 Grey Drake, pseudon. A concise practical treatise on artificial fly fishing for trout. London. [1860.] $8^{\circ}$. pp. 24. Wdcts.

The author describes himself as " an artificial fly-fisher of fifty years' experience." 
Greydrake, Geoffrey, psendon. See Ettingsall, Thomas.

Griffith, Edward. The class pisces, by Baron Cuvier; with additions by Edward Griffith. I 834. $8^{\circ}$. See $\mathrm{Cu}-$ vier, Georges, Baron.

Ang. 49.2I Griffiths, Roger. An essay to prove that the jurisdiction and conservacy of the river of Thames is committed to the lord mayor and city of London both in point of right and usage, by prescription, charters, acts of parliament, \&c. To which is added a brief description of those fish, with their seasons, spawning-times, \&c. that are caught in the Thames, or sold in London, with some few observations on the nature, element, \&c. peculiar to fish in general; also of the water-carriage on the river Thames to the several parts of the kingdom, with a list of keys, wharfs, and docks adjoining to the same. London. I746. $8^{\circ}$.

Published in $175^{8}$ with the tille, "Description of the river Thames, etc.," and claimed by Robert Binnell. The work "appears to have been an appurtenance of the water-bailiffs." - Westwood and Satchell.

Ang. 47.47 Günther, Albrecht (Karl Ludwig Gotthilf). Descriptions of some species of fishes from the Peruvian Amazons. - Contribution to the ichthyology of Tasmania. [London. I 869.] $8^{\circ}$. pp. (7). Wdcts.

Proceedings of the zoölogical society, 1869, pp. 423-429.

Guinther, Albrecht Karl Ludwig Gotthilf. The fishes of Zanzibar. I $866 . \quad 4^{\circ}$. See Playfair, Sir R. L., and Guinther, A. K. L. G.

Ang. 47.5 Ginther, Albrecht Karl Ludwig Gotthilf. An introduction to the study of fishes. Edinburgh. I $880.8^{\circ}$. pp. xvi., 720. Wdcts. and plate.

V. 1342 Another copy.

Guinther, Albrecht Karl Ludwig Gotthilf. An introduction to the study of fishes.

V. 3004 Reviewed in Quarterly review, 1882, cliii. 241-266.

H., R. The anglers sure guide. I 7.06. $8^{\circ}$. See [Howlett, Robert].

Hackle, Palmer, pseudon. See Blakey, Robert.

Haime, Jules. La pisciculture; son histoire et ses progrès dans les pays étrangers et en France. (In Revue dcs denx mondes, I $854,8^{\circ}$, vi. I006-1032.)

Ang. 50.50 Haime, Jules. Pisciculture; [translated by Gamaliel Bradford]. (Appended to MASSACHUSETTS - Commissioners for the artificial propagation of fish. Report, [1857], 8 , pp. 19-54.) 
Ang. 50.90 Haime, Jules. Pisciculture; [translated by Gamaliel Bradford]. (Appended to MARsh, G. P. Report on the artificial propagation of fish, $1857,8^{\circ}$, [ii.] 10-40.)

Reprinted in 1874 with the title, "The history of fish-culture in Europe from its earlier records to $1854 . "$

Ang. 50.2 Haime, Jules. The history of fish-culture in Europe from its earlier records to I 854. (Appended to UNITED STATES-Commission of fish and fisheries. Report for I $872 / 73,8^{\circ}$, pp. $465-492$.)

Onginally published in 1857 under the title, "Pisciculture."

*Ang. I8.86 Halford, Frederic M. Floating flies and how to dress them; a treatise on the most modern methods of dressing artificial flies for trout and grayling, with full illustrated directions, and containing ninety hand-coloured engravings of the most killing patterns. Together with a few hints to dry-fly fishermen. London. I 886. $8^{\circ}$. Wdcts. and 10 col. plates.

*Ang. 22.13 Halieutics by modern writers. [A collection of articles taken from various English and American periodicals, from cir. 1819-1883, and bound together.] 3 vol. $8^{\circ}$. Illustr.

A title-page with contents has been printed for each volume. The title of the second reads, "H $\mathrm{H}$ alieutics by modern anglers."

Contents:- [i.] Angling. - Autumnal trout-fishing in the Lincolnshire wolds. - Among the sea-trout; by A. W. Powell. - Angling worthies; by M. G. Watkins. - Trout and trout-fishing. - Fishing and fishers; by Prof. Leebody. - Trout-fishing in Sutherlandshire; by M. G. Watkins. - Spring trouting; by Redspinner. - North, with a rod; by Alfred Kinnear. - A few days' fishing; by Henry Lake. - Trout in a chalk-stream. - What's a grilse? - Stephen Oliver on angling. - Fishing and fishing literature. - Fly-fishing in Northumberland. - A lounge on the Lea. - New seaside studies. - O'Gorman's Practice of angling. - A few thoughts on fly-fishing. - The rod and the stream; by Titus. - The naturalist in Norway; [trout and their haunts]. Pike-fishing. - Country pleasures; angling and fly-fishing. - The fly-fisher's guide. - Notes on the fishers of the Scotch east coast. - The fisher-folk of the Scottish east coast. - A fortnight's fly-fishing in Brittany. - Fishing in British Columbia. - The broads and rivers of Norfolk and Suffolk. - Fish-markets and fish-ponds. - Pisciculture; its progress and utility. - Eels and eel-sets.

[ii.] Scrope on salmon-fishing. - The salmon and its growth. - The salmon question, how our forefathers treated it; [by S. Walpole]. - Autobiography of the late Salmo Salar, Esq. - About salmon; by Henry Kingsley. - A slice of salmon; by H. F. Hore. - The salmon and its growth. - The herring harvest. - Fish-culture. - Oyster-farming. - The pearl harvest. - A night with a salmon. - The fly-fisher in winter quarters. - My first salmon. Salmon-fishing; IVith a trout-rod: by M. G. Watkins. - Natural history of salmon and sea-trout. - Highland sport. - Scrope's Days and nights of salmon-fishing. - The Lews; its salmon and herring. - Salmon-fisherics of the United Kingdom. - Salmon-fishing in the Canadian river Moisie. - Salmonfishing by net and rod on the river Tay. - The salmon of Clootie's Hole. A chapter on angling. - The last salmon before close time.

[iii.] Fishing in Virginia waters; by J. C. Carpenter. - The bass of the Potomac; by W. M. Laffan. - Ten days' sport on salmon rivers; by Dean 
Sage. - Salmon-fishing on the Novarro; by T. Bennett. - The Androscoggin lakes; by Edward Abbott. - The haunts of the grayling; by Maurice Thompson. - Salmon-fishing on the Nipissiguit; by Thaddeus Norris. - Salmon-fishing in Canada; by S. C. Clarke. - Notes on salmon-fishing; by A. G. Wilkinson. - Adirondack days; by Henry Vane. - The Saranac; Adirondack woods and waters: by T. A. Richards. - The Raquette club; by C. Hallock. - Camp Lou; by M. Cook. - The primitive fish-hook; by Barnet Phillips. - The Michigan grayling; by Thaddeus Norris.- Trout-fishing in the Rangeley lakes; by E. Seymour. - The Mediterranean of America. - Sea-trout fishing. Black-bass fishing; by J. A. Henshall. - The speckled trout; by John Burroughs.-A summer in New England. - Fish-culture in America; by W. F. G. Shanks. - Fish-culture. - The fascinations of angling; by George Dawson. - Pan-fish angling; by M. Thompson. - Hints for practical trout-fishing. Strange sea industries and adventures; by W. W. Harney. - Fishing adventures on the Newfoundland banks. - A Newfoundland fisherman. - How mackerel are caught. - The story of the whale; by T. B. Thorpe.--North Carolina illustrated; by D. H. Strother. - By the river-side; our angling club. - Spring trouting in Kent. - Aboard a "banker." - Salmon. - Salmonbreeding. - Fishing in Norway; by Charles Taylor. - The life of a salmon. - Angling with the worm; by G. C. - Salmon. - The jack; Small fry; The trout; The grayling; The basse; The cod-fishery: by A. H. Baldwin.Touching the oyster. - The salmon; by Edward Jessc.

Ang. 30.4 Hallock, Charles, editor. Camp life in Florida; a handbook for sportsmen and settlers. [New York.] 1876 . I $2^{\circ}$.

"A compilation from the Forest and stream."

Contains "Game fish of Florida" and "Bass fishing on Spruce creek," by S. C. Clarke; "Fishing at St. Augustine;" "Private Dougherty and the bass," H. W. Merrill.

Ang. 25.4 Hallock, Charles. The fishing tourist; angler's guide and reference book. New York. I873. $8^{\circ}$. Front. and vigns.

"Presents in a concise form all the information necessary to enable gentlemen to visit successfully every accessible salmon and trout region of America." - Prefatory.

Ang. 32.9 Hallock, Charles. Our new Alaska; or, The Seward purchase vindicated. Illustrated from sketches by T. J. Richardson. New York. I 886. $8^{\circ}$. Front., wdcts., plate, and map.

"Commercial fisheries," pp. 130-152. - Also several other pages on fishing.

Ang. 25.5 Hallock, Charles. The sportsman's gazetteer and general guide. The game animals, birds, and fishes of North America, their habits and various methods of capture; copious instructions in shooting, fishing, taxidermy, woodcraft, etc. With a directory to the principal game resorts of the country. New York. I877. I $2^{\circ}$. pp. 688, 208. Port., maps, and wdcts.

"Bibliography for sportsmen," pp. 659-667. 
*Ang. 18.84.2 Hamilton, Edward, M.D., F.L.S. Recollections of fly fishing for salmon, trout, and grayling; with notes on their haunts, habits, and history. London. 1884. $8^{\circ}$. Front., vign., and 5 plates.

"100 copies printed. No. 69."

The frontispiece is a mezzotint engraving by F. S. Haden. The plates are woodcuts on India paper, mounted, and are from sketches made on the spot by the author.

*Ang. 1.33 Hamilton (previously BuCHANAN), Francis. An account of the fishes found in the river Ganges and its branches. Edinburgh, etc. 1822. $4^{\circ}$, and atlas of 39 plates, obl. $4^{\circ}$.

The plates are engraved.

46.39 Another copy.

Imperfect: - atlas wanting.

*Ang. 47.28.2 Hamilton, Robert, M.D. British fishes. 2 pt. London, etc. [18-.] Portrs., engr. title-pages, wdcts., and $68 \mathrm{col}$. plates. (In JARDine, Sir William, bart. The naturalist's library, [ $18-], 16^{\circ}$, xxxvi., xxxvii.)

"Memoir of William Rondelet," i. I5-44. - "Memoir of Baron Alexander von Humboldt," ii. I5-39.

46.47 Also in the edition of $1852-54$.

Ang. 29.3 Hammond, Samuel H. Hills, lakes, and forest streams; or, A tramp in the Chateaugay woods. New York, etc. 1854. I $2^{\circ}$. Front., illustr. title-page, and plates.

The same as his "Hunting adventures in the northern wilds."

Chapters 2-5, I 8 describe fishing excursions.

A large portion of this work was originally published in the Albany state register.

I I375.39 Another copy.

Ang. 29.2 Hammond, Samuel H. Hunting adventures in the northern wilds; or, A tramp in the Chateaugay woods, over hills, lakes, and forest streams. Philadelphia. [cop. I 863.] I $2^{\circ}$. Front. and plates.

His "Hills, lakes, and forest streams" with a new title-page.

Chapters 2-5, 18 describe fishing excursions.

*Ang. 29.8 Hammond, Samuel H. Wild northern scenes; or, Sporting adventures with the rifle and the rod. Philadelphia. [cop. 1863.] $12^{\circ}$. Front. and plates.

Ang. 39.56 Hansard, George Agar. Trout and salmon fishing in Wales. London. 1834 . $16^{\circ}$. Vign.

Chatto, in his "Angler's souvenir," says of this work: "It is a perfect gazetteer of every lake and stream in the principality, ample and accurate. . . I see that [the author] has resumed in his book a considerable portion of the article 'Angling' which he must have furnished to Brewster's 'Edinburgh encyclopæedia.', 
Ang. 49.46.6 Harding, Charles (William). Molluscs, mussels, whelks, etc. used for food or bait. London. 1883. $8^{\circ}$. pp. 23. (LONDON, Eng. - International fisheries exhibition, I883. [The fisheries exhibition literature, vi. 9.])

Also another edition.

Ang. 26.3 Hardy, Campbell. Forest life in Acadie; sketches of sport and natural history in the lower provinces of the Canadian dominion. London. I 869. $8^{\circ}$. Col. front., vign., and plates.

"Acadian fish and fishing," pp. 211-260.

Several of the sporting scenes appeared originally in the Field.

Park. II.20 Another copy.

Ang. 26.5 Hardy, Campbcll. Sporting adventures in the New World; or, Days and nights of moose-hunting in the pine forests of Acadia. 2 vol. London. 1855. I $2^{\circ}$. Col. fronts.

Contains many fishing incidents, and a chapter on "Flies and tackle for North American waters."

4355.14 Another copy.

Park. II.I9 Another copy.

*Ang. 18.35.3 Harewood, Harry, pseudon.? A dictionary of sports; or, Companion to the field, the forest, and the river side. Containing explanations of every term applicable to racing, shooting, fishing, etc., with essays upon all national amusements. London, etc. I 835 . I $2^{\circ}$. Wdcts.

This is an improved version of the "Sportsman's dictionary."

Ang. 18.95 Harmsworth, Alfred C. Tarpon fishing in the Gulf of Mexico. Plate and wdcts. (In Bickerdyke, John. Sea fishing, I $895,8^{\circ}$, pp. 445-468.)

Harris, William C., angler, editor. The American angler. See American angler (The). I 88 I, etc.

Ang. 25.6 Harris, William C., angler, compiler. The angler's guide book and tourists' gazetteer of the fishing waters of the United States and Canada. I 885. New York. [ I 885.] I $2^{\circ}$.

*Ang. 46.6 Harting, James Edmund. Essays on sport and natural history. London. $1883.48^{\circ}$. Port. and wdcts.

"Fishing notes in Holland," pp. 217-221; "Fishing with cormorants," pp. 423-440.

Ang. 18.64 Hartung, Eduard. Der praktische angler; oder, Die geheimnisse alle arten fische und krebse in flïssen, bächen, und teichen mit der angel und in reusen auf die einfachste weise $z u$ fangen, und der anweisung wie fische in fischteichen zu ziehen sind. Nach eigenen erfahrungen und englischen methoden herausgegeben. Quedlinburg, etc. I 864. I $6^{\circ}$. 
*Ang. 39.14 Hassell, John. Excursions of pleasure and sports on the Thames; illustrated in a series of engravings in aquatinta, coloured after nature. Accompanied by a descriptive and historical account of every town, village, mansion, and the adjacent country on the banks of that river, the places and periods for enjoying angling, shooting, sailing, \&c.; also a particular account of all places of amusement in its vicinity, and the list of inns and taverns. London. 1823. I $6^{\circ}$. Col. front. and $23 \mathrm{col}$. plates.

"Angling on the Thames," pp. 36-56.

The illustrations are by the author.

*Ang. 44.35 [Hawes, William Post.] Sporting scenes and sundry sketches; being the miscellaneous writings of J. Cypress, jr. [pseudon.]. Edited by Frank Forester [H. W. Herbert]. 2 vol. New York. I 842. I $2^{\circ}$. Fronts. and plates.

"Memoir," i. I-14.

Contents:-i. Fire Island ana; or, A week at the Fire Islands. - Controversy concerning the genera and distinctions of quail and partridge; by J. Cypress, jr. and Frank Forester.-Bear.-Collineomania.-Legęnds of Long Island.

ii. Classic rhapsodies. - Random reminiscences. - Miscellanies.

The eight chapters "Fire Island ana," contain some references to fishing.

AL 1728.9.9I Another copy.

Hawks, Francis Lister, compiler. Narrative of the expedition of an American squadron to the China seas and Japan. See Perry, M. C. Narrative, etc. I $856.4^{\circ}$. Note.

Ang. 29.4 Headley, Joel Tyler. The Adirondack; or, Life in the woods. New York. I 849 . I $2^{\circ}$. Front. and plates.

Parts of chapters $1,2,14,18,23,24,26,28$ are on angling.

"The letters in this volume embrace two different summers spent in the forest." - Preface.

*Ang. 18.79.3 Henderson, William, of Durham, Eng. My life as an angler. London. I 879. $8^{\circ}$. Port., plates, and wdcts.

This is substantially the same as the work printed for private circulation in 1876, entitled "Notes and reminiscences of my life as an angler." New matter has been added, however, and portions of the earlier work withdrawn. The portrait is a Woodburytype, and the head and tail pieces were designed by Mrs. William Henderson.

"One of the most sterling and attaching of modern angling books." Westwood and Satchell.

Henle, Jakob. Systematische beschreibung der plagiostomen. I841. fo. See Miiller, Johannes, and Henle, Jakob. 
*Ang. I8.8I.3 Henshall, James A. Book of the black bass; comprising its complete scientific and life history. With a practical treatise on angling and fly fishing, and a full description of tools, tackle, and implements. Cincinnati. 1881. sm. $8^{\circ}$. Port., plates, and wdcts.

"The full-page illustrations of the two species of black bass were drawn from life by E. R. Copeland."

*Ang. 30.3 Henshall, James A. Camping and cruising in Florida. Cincinnati. 1884. $8^{\circ}$. Front., map, plates, and wdcts.

"List of fishes observed by the author in Florida," pp. 235-24I.

Most of the chapters contain a few pages on fishes and fishing.

"Sketches originally published in the Forest and stream and the American field. . . . Most of the illustrations are original pen-drawings by G. W. Potter."-Preface.

Ang. 49.43 Herbert, David, editor. . Fish and fisheries; a selection from the prize essays of the international fisheries exhibition, Edinburgh, I 882. Edinburgh, etc. 1883. $8^{\circ}$. Plates, maps, and plans.

Three of the plates are photographs.

Contents:- MÜLLER, H. $\dot{\mathrm{C}}$. Whale-fishing in the Faröe isles. - Sмith, W. A. Various methods of oyster culture. Oyster cultivation in Scotland:Sim, George. The, natural history of the herring. - WATT, William. The natural history of the herring. - YouNG, Archibald. Harbour accommodation for fishing-boats on the east and north coasts of Scotland. - SмIтH, W. A. Curing and preserving fish at home and abroad. - Ross, John. Curing and preserving fish in Scotland and its islands. - LeITH, J. M. Salmon legislation in Scotland. - WrLcocks, J. C. The best means of increasing the supply of mussels for bait. - Brotherston, Antrew. The salmon disease.Morris, C. W. The mesh of herring nets. - Chambers, W. O. The artificial propagation of sea-fishes suitable for food. The breeding and rearing of fresh-water fish. Foreign fish most suitable for introduction into British rivers and waters. - Syith, W. A. The utilisation of fish offal.-MATTHEY, Albert. Sur la pêsche de la truite à Vallorbes. - SMiтh, W. A. The fish supply of great cities. - MiLN, W. S. The herring brand. - Epton, J. The migrations and spawning of sea-fish suitable for food. - BRADFIELD, $\mathrm{H}$. Angling associations. - Low, Alexander. Angling associations. - Maclean, A. J. The best modes of preserving ice. - Ross, John. The best modes of preserving ice. - WILCOCKS, J.C. Seine-trawling and beam-trawling in estuaries and sea-lochs in Scotland. The history and statistics of the pilchard fishery in England. - WATT, William. The history and statistics of the herring fishing in Norway and Sweden. - Strinling, J. Trout-fishing on our Highland lochs. - OMOND, James. Model of the safest and handiest sailing fishing-boat, as to hull, sails, spars, and rig.

46.32 Herbert, Henry William. Frank Forester's fish and fishing of the United States and British provinces of North America. London. 1849. $8^{\circ}$. Wdcts. and 4 plates.

Imperfect: - half-title wanting.

"How to cook fish," pp. 436-455.

Most of the illustrations were drawn by the author.

Ang. 47.19 Another copy.

One of the plates is used as a frontispiece. 
Ang. 47.20 Herbert, Henry William. Frank Forester's fish and fishing of the United States and British provinces of North America. New ed., revised and corrected, with an ample supplement by the author, together with a Treatise on fly-fishing, by "Dinks" [Jonathan Peel]. New York. I 864 [cop. 1859]. $8^{\circ}$. Front., wdcts., and 12 plates.

One of the plates is colored.

Ang. 22.9 [Herbert, Henry William.] Frank Forrester's fishermens' [sic] guide; a manual for professional and amateuer [sic] anglers. Containing descriptions of popular fishes and their habits, preparation of baits, \&c., with a list of tools used in fishing; making it the most complete work on the subject yet published. New York. [ $18-.] \mathrm{sm} .8^{\circ}$. pp. 64. Front., plates, and wdcts.

*Ang. 44.37 Herbert, Henry William. Life and writings of Frank Forester (H. W. Herbert). Edited by D. W. Judd. 2 vol. New York. 1882. $12^{\circ}$. Port., front., plates, and vigns.

"Life," by Thomas Picton, i. I1-104.

"Sketches which were scattered through various periodicals, or were never published. The illustrations are by Charles Hinkle." - Preface.

"Trouting along the Catasauqua," i. 270-300; "The smelt of the Passaic," ii. 97-107; "The smelt of the Raritan and Passaic," ii. 23I-235.

The publishers planned a third volume, which evidently never appeared.

Ang. 39.3I Hicks, John. Wanderings by the lochs and streams of Assynt and the north Highlands of Scotland. London. 1855. I $6^{\circ}$. Front. and plates.

Describes fishing in these regions. The illustrations are from sketches by the author. The two colored plates of flies represent those "found to be the most killing in the lochs of Assynt."

*Ang. 39.II Highley, Samuel. Where to fish round London. London. [1882.] sm. $8^{\circ}$. pp. (6), 56.

Hill, Richard. A naturalist's sojourn in Jamaica. $185 \mathrm{I}$. I $2^{\circ}$. See Gosse, P. H.

*Ang. 39.6I Hi-Regan, pseudon. How and where to fish in Ireland ; a hand-guide for anglers. $3 \mathrm{~d}$ ed. London. 1887. $\mathrm{sm} .8^{\circ}$. Map and wdcts.

Contains many illustrations and descriptions of tackle.

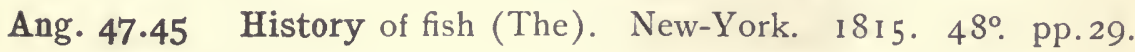
Wdcts.

Ang. 48.19 Hoare, J. A treatise on fishponds; addressed to the nobility and gentry of Sussex. London. I870. $8^{\circ}$. pp. (4), 49. 
Ang. 49.46. II . Hoek, Paulus Peronius Cato. Oyster culture. Prize essay. London. I $884.8^{\circ}$. pp. 36.3 plates. (LonDON, Eng. - International fisheries exhibition, I 883. [The fisheries exhibition literature, xi. I4.])

Also another edition.

Ang. 18.39.2 Hofland, Thomas Christopher. The British angler's manual; or, The art of angling in England, Scotland, Wales, and Ireland, with some account of the principal rivers, lakes, and trout streams in the United Kingdom. With instructions in fly-fishing, trolling, and angling at the. bottom, and particularly for the trout. London. 1839.

1. I $2^{\circ}$. Front., plates, and wdcts.

Most of the illustrations are "from original pictures and drawings by the author."

*Ang. $18 \cdot 39 \cdot 3$

and wdcts.

The same. London. I841. 8\%. Front., plates,

This is a paginal reprint of the first edition. The plates are on China paper, mounted.

*Ang. 18.39.4 — The same. New ed., revised and enlarged by E. Jesse. London. I 848 . sm. $8^{\circ}$. Front., plates, and wdcts.

"Memoir," by T. R. Hofland, pp. vii.-xvii.

This edition contains additional illustrations.

Ang. 49.46.II Hogarth, Ronald. The herring fishery. Prize essay. London. I $884 . \quad 8^{\circ}$. pp. 23. (LONDON, Eng. - International fisheries exhibition, I883. [The fisheries exhibition literature, xi. 8.])

Also another edition.

Ang. 48.32 Hogg, John ( I 800-1 869). On the distribution of certain species of fresh-water fish, and on the modes of fecundating the ova of the salmonidx. Read before the Tyneside naturalists' field club, Feb. 21, 1856. Newcastle-uponTyne. I $856 . \quad 8^{\circ}$. pp. 17.

*Ang. I.23 Holbrook, John Edwards. Ichthyology of South Carolina. Vol. i. Charleston, S. C. I860. $4^{\circ} .28$ col. plates. No more published.

The plates of the original edition were destroyed by fire, and as but few numbers had been distributed, they were recalled, and replaced by those of the new and improved editior. "The new drawings are from nature, and have been made by the best artists, as A. J. Ibbotson, and A. Sonrel. The colour of the fish has been, in almost every instance, taken from living specimens by J. Burkhardt." - Preface.

Ang. 49.46 Holdsworth, Edmund William Hunt. Apparatus for fishing. London. I883. $8^{\circ}$. pp. 80. (London, Eng. -International fisheries exhibition, 1883 . [The fisheries exhibition literature, i. 4.])

Also another edition. 
Ang. 49.5 Holdsworth, Edmund William Hunt. Deep-sea fishing and fishing boats. An account of the practical working of the various fisheries around the British islands, with descriptions of the boats, nets, and other gear in use. London. . 1874. $8^{\circ}$. Front., plates, and wdcts.

The illustrations were drawn by the author.

*Ang. 49.34 Holdsworth, Edmund William Hunt. Sea fisheries, by Ang. 49.33 E. W. H. Holdsworth. Salmon fisheries, by Archibald Young. London. 1877 . I $6^{\circ}$. Plate and wdcts. (BEVAN, G. P., editor. British industries.) 2 cop.

Home, David Milne. See Milne-Home.

Ang. 44.39 Hood, Thomas (1799-1845). Hood's own, or, Laughter from year to year; being former runnings of his comic vein, with an infusion of new blood for general circulation. [ist series.] London. I $839.8^{\circ}$. Port. and wdcts.

"The angler's farewell" [a poem], pp. 139-140.

Ang. 44.39.2 — The same. Being a further collection of his wit and humour, with a preface by his son. $2 \mathrm{~d}$ series. London. [I86I.] $8^{\circ}$. Wdcts.

"A rise at the father of angling" [a poem], pp. 20-24; "Review: The rambles of Piscator, by Sylvanus Suburban," pp. 50-55; "Mr. Chubb, a piscatory romance," pp. 298-312; "Walton redivivus," pp. 433-438.

*Ang. 18.74.2 Horrocks, John. Die kunst der fliegenfischerei auf forellen und aschen in Deutschland und Oesterreich. Weimar. $1874.8^{\circ}$. Col. front., wdcts., and 4 col. plates.

The author, an Englishman, who has lived in Germany for thirty years, writes to instruct the Germans in the art of fly-fishing, of which, he says, they have little knowledge.

*Ang. I.5 Houghton, William. British fresh-water fishes. Illustrated with a coloured figure of each species, drawn from nature by A. F. Lydon. 2 vol. (paged contin.). London, etc. [1879.] fo. Col. fronts., walcts., and 39 col. plates.

"Titles of works quoted," [ii.] 202.

Ang. 49.46.1o Houghton, William. The natural history of commercial sea fishes of Great Britain and Ireland, with special reference to such parts of their natural history as bear upon their production and commercial use. Prize essay. London. I $884.8^{\circ}$. Front. and I I plates. (London, Eng. - International fisheries exhibition, I883. [The fisheries exhibition literature, x. I.])

Also another edition.

VIII. 39I (xi) Houghton, William. The natural history and cultivation of the sole. (In LONDON, Eng. - International fisheries exhibition, 1883. The fisheries exhibition literature, I $884,8^{\circ}$, xi. $225-263$.) 
*Ang. 18.88.3 How to catch trout. By three anglers. Edinburgh. I888. I $6^{\circ}$. pp. (2), vi., 83. Wdcts.

Ang. 49.46.2 Howes, George Bond. Zoölogy and food fishes. London. I883. $8^{\circ}$. pp.70. (London, Eng.-International fisheries exhibition, I883. [The fisheries exhibition literature, ii. 2.])

Also another edition.

Howitt, Samuel, illustrator. The angler's manual. With twelve plates, designed and etched by S. Howitt. See Angler's manual (The). 1808. $24^{\circ}$.

*Ang. 1.39 Howitt, Samuel, and others. Foreign field sports, fisheries, sporting anecdotes, \&c.; from drawings by Howitt, Atkinson, Clark, Manskirch, \&c. With a supplement of New South Wales, [by J. H. Clark]. London. 1814. $4^{\circ}$. I 10 plates.

The supplement has a special title-page, "Field sports, \&c. of the native inhabitants of New South Wales. I813."

The plates on fishing subjects are " Russian winter fishery," "Killing a shark," "Turtle fishing in the water," " Mackerel fishing," "Torch light fishing in N. America," four on whale fishing, and two on fishing in New South Wales. Thirteen plates represent Spanish bull fighting.

*Ang. 39.6 Howitt, William. The rural life of England. 2 vol. London. 1838 . $12^{\circ}$. Vigns.

Vol. i., chapter 4 of pt. I, chapter 6 of pt. 2, vol. ii., chapter I 2 of pt. 3 , contain a few pages on angling.

With three exceptions, the illustrations were designed and engraved by Samuel Williams.

8456.8 Another copy.

8456.10 The same. From the $2 \mathrm{~d}$ London ed., corrected and revised. Philadelphia. I84I. 1. 1 $2^{\circ}$. Front.

Ang. 4946.7 Howitz, D. Forest protection and tree culture on water frontages, with the view of providing a constant and steady supply of water, food, shade, and shelter for freshwater fish. London. I883. $8^{\circ}$. pp. 16. (LONDON, Eng. - International fisheries exhibition, 1883. [The fisheries exhibition literature, vii. I0.])

Also another edition.

Ang. 17.06 [Howlett, Robert.] The anglers sure guide; or, Angling improved and methodically digested. Shewing the various and choicest ways of dressing [fresh-water fish], with many other useful and pleasant varieties suitable to the recreation of angling. By R. H. London. I 706. sm. $8^{\circ}$. Front. and plate.

This work bears a close resemblance to Chetham's "Angler's vade mecum."

"Generally attributed to Robert Howlett." - Westroood and Satchell. 
Ang. 28.9 Hubbard, Lucius Lee. Summer vacations at Moosehead lake and vicinity; a practical guide-book for tourists. Describing routes for the canoe-man over the principal waters of northern Maine, with hints to campers, and estimates of expense for tours. Boston. I879. I $6^{\circ}$. 20 plates and map.

The plates are Albertypes.

"Game and fish of northern Maine," "Game and fish laws," pp. I29134. Also mentions the places where good fishing is to be found.

For 3 d edition, see his "Guide to Moosehead lake and northern Maine." 1882. $16^{\circ}$.

Ang. 28.6 Hubbard, Lucius Lee. Woods and lakes of Maine; a trip from Moosehead lake to New Brunswick in a birchbark canoe. To which are added some Indian place-names and their meanings, now first published. Boston. I 884 [1883]. 8. Front., wdcts., and maps.

Contains a few pages on fishing.

The illustrations are by W. L. Taylor, who accompanied the author on this excursion.

I03I7.8 Another copy.

Ang. 49.46.5 Hubrecht, A. A. W. Oyster culture and oyster fisheries in the Netherlands. London. I883. $8^{\circ}$. pp. 30. (London, Eng. - International fisheries exhibition, I 883. [The fisheries exhibition literature, v. 2.])

Also another edition.

Ang. 18.88.4 Hudson, Frank. Sea fishing for amateurs; a book of practical instruction on the best methods of sea fishing from the shore, rocks, or jetties. London. I888. $\mathrm{sm} .8^{\circ}$. pp. 79. Wdcts.

Contains a list of the principal fishing stations on the English and Welsh coasts.

Ang. 18.42 [Hughes, William (1803-I 86I).] The practical angler. By Piscator. London. I 842. $8^{\circ}$. Front. and plates.

With the armorial book-plate of Samuel T. Tisdale.

Ang. 49.8 [Hughes, William (1803-186I).] A practical treatise on the choice and cookery of fish. By Piscator. $2 \mathrm{~d}$ ed. London. I 854 . I $6^{\circ}$.

With the armorial book-plate of William Keale Heseltine.

Ist edition, I 843, with the title, "Fish; how to choose and how to dress."

Ang. 49.46.6 Huxley, Thomas Henry. Fish diseases. London. I 883. $8^{\circ}$. pp. 3 I. (LONDON, Eng.-International fisheries exhibition, 1883. [The fisheries exhibition literature, vi. I.])

"Not fish diseases in general, but . . . the so-called salmon disease." - Page 3.

Also another edition. 
Ang. 49.46.4 Huxley, Thomas Henry. Inaugural meeting of the fishery congress. Address delivered June I 8, I 883. London. I883. 8\%. pp. 22. (LoNDON, Eng.-International fisheries exhibition, 1883. [The fisheries exhibition literature, iv. I.])

Also another edition.

Ang. 18.55.4 Idle, Christopher, pseudon. Hints on shooting and fishing, \&c., both on sea and land, and in the freshwater lochs of Scotland. Being the experiences of Christopher Idle. London. I 855 . I $6^{\circ}$.

Ang. 18.55.5 The same. 2d ed. London. I $868.16^{\circ}$. This edition has been revised and enlarged by the author.

Ang. 50.33 Illinois - Fish commission. Report from I879-1882, 1884-1886. 4 pam. Springfield. I880-86. $8^{\circ}$. Front., plates, and diagrs.

*Ang. I.46 Illustrated London almanack (The), for I864. Containing astronomical illustrations printed in tints, original designs as headings to the calendar, pictures of fresh-water fish printed in colours, numerous fine-art engravings, and a variety of useful information. London. [1863.] 1. $8^{\circ}$.

"Fresh-water fishes in their season," pp. $8,18,28,38,48,58$.

*Ang. 45.42 Innocent epicure (The); or, The art of angling. A poem. London. 1697. 16\%. pp. (16), 64.

The preface is signed " $N$. Tate," to whom the poem is sometimes attribuled; but the preface is followed by a paraphrase on Horace Epist. x. lib. I, addressed "From J. S. to C. S." This J. S. is supposed by some to be the author of the "True art of angling."

Westwood says that this edition has become rare. A later edition was published under the title, "Angling; a poem."

With the armorial book-plate of James Maidment.

Ang. 45.43 [Ireland, Samuel William Henry.] The fisher boy; a poem. Comprising his several avocations during the four seasons of the year. By H. C., Esq. [London. I 808.] $16^{\circ}$.

The title-page is engraved.

Ireland is best known as the forger of the Shakespeare papers.

*Ang. 44.42 Irving, Washington. The angler. N. P. [18-. $] 8^{\circ}$. pp. ( I6). Wdcts.

From his "Sketch book," pp. 435-448.

Ang. 45.50 Isys, Cotswold, pseudon. An angler's strange experiences; a whimsical medley, and an of-fish-all record without a-bridge-ment. Illustrated in a style never before app-roach-ed in these days, after drawings in water-colours. London. 1883. sm. $4^{\circ}$. Front. and redcts.

Poems on angling. 
*Ang. 18.54.3 Jackson, John, of Tanfield Mill. The practical flyfisher; more particularly for grayling or umber. $3 \mathrm{~d}$ ed. London, etc. $1880 . \quad 8^{\circ}$. pp. (4), 57+. Wdcts. and 10 col. plates.

Biographical sketch, pp. 45-46.

This work is dedicated to T. H. B., i.e. T. H. Barker, who completed it after the death of the author.

Ist edition, 1854 .

Ang. I7.r8 [Jacob, Giles.] The compleat sportsman; in three parts. I. Containing the nature and various kinds of game, with the best methods of taking the same. 2. Of the best situations and methods of erecting and management of parks, \&c., of hunting the buck, doe, \&c. 3. Of fish and fishing; the most successful methods of angling, the only proper baits, tackle, and seasons for taking all sorts of fish, etc. [London.] i 7 I 8. sm. I $2^{\circ}$.

"Fish and fishing," pp. I14-152.

Ang. 48.12 Jacobi, Stephen Ludwig. Lettre sur la fécondation artificielle des œufs de saumon et de truite. Wdct. (Appended to Coste, J. J. M. C. V. Instructions pratiques sur la pisciculture, $1853.12^{\circ}$, pp. I 30-1 39.)

Written in 1763 to the editor of the Hannoverisches magazin. Other articles on fish culture by the same author appeared in this magazine. An English translation of one of them was published in London in 1778 , signed S. L. Jacobs, and is said to be the first notice in English of fish culture.

Ang. 49.I I James, William Powell. From source to sea; or, Gleanings about rivers in many fields. London. I884. $\mathrm{sm} .8^{\circ}$.

"They are treated successively as physical phenomena and geological agents, as elements of picturesque scenery, as the seats of vegetable and animal life, and as connected with the history, religion, and industry of man. Finally, a slight contribution is made to the difficult task of determining the meaning of their names."-Preface.

Ang. 47.28.3 Jardine, Sir William, bart. The natural history of fishes of the perch family. Edinburgh, etc. 1835. Port. of Sir Foseph Banks, engr. title-page, wdcts., and 34 plates. (In his Naturalist's library, $1835,16^{\circ}$, [xxxviii.].)

"Memoir of Sir Joseph Banks," pp. 17-48.

The engraved title-page and all of the plates but two, are colored.

This is called "Naturalist's library. Ichthyology. Vol. i."

46.47 The same. [With an appendix.] Edinburgh, etc. 1852. Port. of Sir Foseph Banks, engr. title-page, wdcts., and 35 plates. (In his Naturalist's library, 1852, I $6^{\circ}$, xxxviii.)

"Memoir of Sir Joseph Banks," pp. 15-48.

The engraved title-page and all of the plates but two, are colored.

The appendix consists of extracts from Walton's "Complete angler" containing observations on the perch, etc. 
Jardine, Sir William, bart. The naturalist's library. Vol. xxxv.-xl. Ichthyology. 6 vol. London, etc. [18-], '35. I 6'. Portrs., engr. title-pages, wdcts., and col. plates. Namely:-

Ang. 47.28 xxxv. Fishes, particularly their structure and economical uses; by J. S. Bushnan. [18-.]

*Ang. 47.28.2 xxxvi., xxxvii. Brilish fishes; by R. Hamilton. 2 pt. [18-.]

*Ang. 47.28.3 [xxxviii.] The perch family; by Sir William Jardine. 1835.

Ang. 47.28.4 xxxix., xl. Fishes of British Guiana; by R. H. Schomburgk. 2 pt. [18-.]

Ang. 44.45 Jeans, Thomas. The Tommiebeg shootings; or, A moor in Scotland. With illustrations by Perceval Skelton. London, etc. [1864?] sm. $8^{\circ}$. Front. and plates.

Several of the chapters treat of angling.

Ang. 44.47 [Jefferies, Richard.] The gamekeeper at home; sketches of natural history and rural life. With illustrations by Charles Whymper. Buston. I $880.8^{\circ}$. Front. and wdcts.

Ist edition, 1878 .

The preface is signed " $\mathrm{R}$. J."

"Fish poaching," pp. 184-195.

20446.3

The same. New ed. London. I887. sm. $8^{\circ}$.

Ang. 49.28 Jenner, Thomas. Londons blame, if not its shame; manifested by the great neglect of the fishery, which affordeth to our neighbor nation yeerly the revenue of many millions, which they take up at our doors, whilst with the sluggard we fold our hands in our bosoms and will not stretch them forth to our mouths. Or, The inestimable riches of the British seas, which do yeild a monthly harvest of several fish in their season. [London.] $165 \mathrm{I} . \mathrm{sm} .4^{\circ}$. pp. (2), I4.

Ang. 39.7 Jesse, Edward. An angler's rambles. I ondon. I 836. I $2^{\circ}$. Wdcts.

Reviewed by J. Mitford in the Gentleman's magazine, Nov. 1836 . The greater part of "Thames fishing" originally appeared in Fraser's magazine, Jan. 1834 .

Ang. 39.8 Jesse, Edward. Favorite haunts and rural studies; including visits to spots of interest in the vicinity of Windsor and Eton. London. 1847 . I $2^{\circ}$. Front, plates, and vigns.

Contains one or two allusions to fishing.

Ang. 46.II Jesse, Edward. Gleanings in natural history, with local recollections. To which are added Maxims and hints for an angler. London. I $832 . \mathrm{sm}, 8^{\circ}$. Wdcts. and plate.

Eels, pp. 28-47; Fishes, pp. 72-9o.

"Maxims and hints for an angler," pp. 29I-308. They were written in the album of a fishing club by a friend of the author, and signed " $R$. P. 3Ist May, I829." 
Ang. 46.12 Jesse, Edward. Gleanings in natural history, with local recollections, etc. New ed. London. I $832 . \quad$ sm. $8^{\circ}$. Front. and redcts.

Ang. 46.12.2 The same. $2 \mathrm{~d}$ series. To which are added some extracts from the unpublished MSS. of Mr. White of Selborne. London. I834. sm. 8\%. Fac-sim. and wdcts.

Eels, pp. 43-80, 309; "The finny tribe," pp. 128-132; "The salmon," pp. 305-308.

*Ang. 46.15 Johns, Charles Alexander. Home walks and holiday rambles. London. [I863.] sm. $8^{\circ}$. Front., plates, and wdcts.

Natural history notes, with many observations on birds, and some angling matter.

Jolly angler (The). [I84-.] I $2^{\circ}$. See [March, J.].

Ang. 49.46.5 Joncas, Louis Zepherin. The fisheries of Canada. London. I 883. $8^{\circ}$. pp. 56. (LoNDON, Eng.-International fisheries exhibition, I883. [The fisheries exhibition literature, v. 3.])

Also another edition.

Ang. 39.63 Jones, Griffith Evan. Confessions of a Welsh salmon poacher. London. I877. $8^{\circ}$. pp. 59.

"Originally appeared in Land and water."

*Ang. 46.13 Jones, William, F.S.A. The broad, broad ocean, and some of its inhabitants. New ed. London. [1879.] sm. $8^{\circ}$. Front. and plates.

" Modes of fishing in various countries," pp. 268-309.

Jones's guide to Norway. I848. I $6^{\circ}$. See Tolfrey, Frederic, editor.

46.49 Jonston, Jan. Historiæ naturalis de piscibus et cetis libri v. Francofurti ad Moenum. [1649?] fo. 45 plates.

Imperfect:- plates 15 and 16 wanting.

The title-page is engraved.

Ang. 1.6 The same. [Heilbronn.] i 767. f ${ }^{\circ} .47$ plates. Ang. 50.2 Jordan, David Starr. A catalogue of the fishes known to inhabit the waters of North America north of the tropic of Cancer, with notes on the species discovered in I 883 and 1884. (Appended to UNITED STATESCommission of fish and fisheries. Report for $1885,8^{\circ}$, pp. 789-973.) 
Ang. 50.2.4 Jordan, David Starr. Contributions to North American ichthyology. Based primarily on the collections of the United States national museum. i.-iii. Washington. I 877-78. $8^{\circ}$. Plates. (U. S. National museum. Bulletin, 9, 10, I2.)

Bibliography of American fresh-water siluridæ, ii. 105-110.-Bibliography of catostomidx, iii. 221-230.

Contents:-i. Review of Rafinesque's memoirs on North American fishes; [chiefly a list of the genera, subgenera, and species of the Ichthyologia ohiensis]. 1877 .

ii. Notes on cottidæ, etheostomatidæ, percidæ, centrarchidæ, aphododeridæ, dorysomatidx, and cyprinidæ, with revisions of the genera and descriptions of new or little known species. - Synopsis of the siluridæ of the fresh waters of North America. 1877 .

iii. On the distribution of the fishes of the Alleghany region of South Carolina, Georgia, and Tennessee, with descriptions of new or litle known species; by D. S. Jordan and A. W. Brayton. - A synopsis of the family catostomidæ; by D. S. Jordan. 1878 .

VIII. 39(9, IO, I 2) Another copy.

122.23 The same. i.-iii. (in 2 vol.). Washington. 187778. Plates. (In Smithsonian miscel. coll., i 878 , etc., $8^{\circ}$, xiii. 9 , I0, xxiii. 2.)

Ang. 46.Io Jordan, David Starr. Science sketches. Chicago. I 888. sm. $8^{\circ}$.

Contents:- The story of a salmon. - Johnny Darters. - The salmon family. - The dispersion of fresh-water fishes. - The nomenclature of American birds. - An eccentric naturalist [C. S. Rafinesque-Schmaltz]. - A Cuban fisherman [Felipe Poey y Aloy]. - Darwin. - The story of a stone.-An ascent of the Matterhorn. - The evolution of the college curriculum. - Appendix : List of the scientific papers of D. S. Jordan.

Ang. 47.36 Karr, Alphonse. Dictionnaire du pêcheur. Traité complet de la pêche en eau douce et en eau salée; histoire, mœurs, habitudes des poissons, crustacés, testacés, etc., lois, usages, procédés, ruses et secrets des pêcheurs. Paris. I 855 . I $8^{\circ}$.

For later edition, see his "La pêche en eau douce et en eau salée."

I 544. I6 Karr, Alphonse. La pêche en eau douce et en eau salée. Histoire, mœurs, habitudes des poissons, crustacés, testacés, etc., lois, usages, procédés, ruses et secrets des pêcheurs. Paris. I860. I $8^{\circ}$.

Half-title:- "Cuvres complètes."

For Ist edition, see his "Dictionnaire du pêcheur."

Ang. 18.86.3 Keene, John Harrington. Fishing tackle; its materials and manufacture. A practical guide to the best modes and methods of making every kind of appliance necessary for taking freshwater fish, and for the equipment of the angler and fly-fisher. London, etc. [1886.] sm. $8^{\circ}$. Front., wdcts., and 4 plates. 
*Ang. 18.8r:4 Keene, John Harrington. The practical fisherman; dealing with the natural history, the legendary lore, the capture of British freshwater fish, and tackle and tackle making. London. I $88 \mathrm{I}$. sm. $8^{\circ}$. Front., plates, and wdcts.

Osmund Lambert in his "Angling literature in England" says that this work " cannot be too highly spoken of. It contains some of the most beautiful drawings of fish ever published."

Ang. 38. ro Kemp, John, Esq. Shooting and fishing in Lower Brittany. A complete practical guide to sportsmen. London. 185.9. 1. $12^{\circ}$. Map.

*Ang. I.35 Kennard, Edward. Norwegian sketches. Fishing in strange waters. [A series of 30 lithographic plates.] London, etc. - I 888 . obl. $4^{\circ}$.

I2364.40 [Kennedy, Pendleton.] The Blackwater chronicle. A narrative of an expedition into the land of Canaan, in Randolph county, Virginia; a country flowing with wild animals, such as panthers, bears, wolves, \&c., with innumerable trout - by five adventurous gentlemen without any aid of government, and solely by their own resources, in the summer of $185 \mathrm{I}$. By " the clerke of Oxenforde." With illustrations from life by Strother. New York. 1853. $12^{\circ}$. Front., illustr. title-page, and wdcts.

*Ang. 25.7 Kennedy, William Robert. Sport, travel, and adventure in Newfoundland and the West Indies. With illustrations by the author. Edinburgh, etc. 1885. $8^{\circ}$. Col. front., wdcts., plate, and map.

Contains some account of fisheries and fishing.

Ang. 49.46.4 Kennett-Barrington, Sir Vincent Hunter Barrington. River pollution by refuse from manufactories and mines, with some remedies proposed. London. 1883. $8^{\circ}$. pp. 64. (LONDON, Eng. - International fisheries exhibition, I 88. [The fisheries exhibition literature, iv. 7.])

Also another edition.

Ang. 49.46.6 Kent, William Saville. On the artificial culture of lobsters. London. 1883. 8\%. pp. 23. (London, Eng. - International fishcries exhibition, 1883 . [The fisheries exhibition literature, vi. Io.])

Also another edition.

Ang. 49.46 Kent, William Saville. Handbook of the marine and freshwater fishes of the British Islands, including an enumeration of every species. London. 1883. $8^{\circ}$. Wdcts. (London, Eng. - International fisheries exhibition, 1883 . [The fisheries exhibition literature, i. 2.])

Also another edition. 
Ang. 49.46.5 Kent, William Saville. Report upon the sponges of the Bahama islands. (Appended to AdDERley. Sir A. J. The fisheries of the Bahamas, I $883,8^{\circ}$, pp. 30-56.)

Also in other edition.

*Ang. I8.04 Kentish angler (The); or, The young fisherman's instructor. Shewing the nature and properties of fish which are generally angled for in Kent, rules and cautions to be observed by young anglers, etc. By an experienced angler. Canterbury. I 804. sm. I $2^{\circ}$. pp. 40 t. Front.

With the armorial book-plate of Joseph Crawhall.

"One of the rare local books." - Westwood and Satchell.

Ang. 49.27 Keymor, John. Observation made upon the Dutch fishing, about the year I60I; demonstrating that there is more wealth raised out of herrings and other fish in His Majesties seas by the neighbouring nations in one year, then the king of Spain hath from the Indies in four. London. r664. sm. $4^{\circ}$. pp. (2), 12.

Reprinted in the Phoenix, vol. i., 1707.

Ang. I8.20.2 Kidd, William, bookseller. Practical instructions in the art of angling; with many novel directions for the better enjoyment of the "gentle art," adapted to the use of young as well as experienced anglers. London. [I820.] $24^{\circ}$. pp. 36. Front. and zedcts.

"The frontispiece of a gentleman in tartan and a lady in evening dress, has a quotation from the 'Sportsman's dictionary' setting forth that angling is a 'particularly pleasant pastime, to which the presence of one's 'ladye-love' lends a no small additional charm." - Westwood and Satchell.

VIII. 39(2,3) Kidder, Jerome Henry, editor. Contributions to the natural history of Kerguelen island, made in connection with the American transit-of-Venus expedition, I 874-75. 2 vol. Washington. I875-76. $8^{\circ}$. (U. S. NATIONAL Museum. Bulletin, 2, 3.)

Contents :-i. Ornithology; edited by Elliott Coues. 1875 .

ii. Oülogy. - Botany. - Geology. - Mammals. - Fish. - Mollusks. - Insects. - Crustaceans. - Annelids. - Echinoderms. - Anthozoa. - E. Kershner's collection. - A study of chionis minor with reference to its structure and systematic position; by J. H. Kidder and Elliott Coues. 1876.

Ang. 50.2.4(3) Another copy of ii.

I22.23 The same. 2 vol. in 1. Washington. I875-76. (In SMITHSONIAN miscel. coll., I $878,8^{\circ}$, xiii. $2,3$. )

Ang. 49.46.7 Kilbourn, J. K. Fish preservation and refrigeration. London. 1883. 8\%. pp. 28. (LONDON, Eng.-International fisheries exhibition, 1883 . [The fisheries-exhibition literature, vii. 8.])

Also another edition. 
Ang. 26.12 King, John Lyle. Fishing on the Nipigon. [Chicago? I883?] $8^{\circ}$. pp. IO.

"Reprinted from the American field, Sept. 15, 1883."

*Ang. 32.I King, John Lyle. Trouting on the Brule river; or, Summer-wayfaring in the northern wilderness. New York. I 880 . sm. $8^{\circ}$. Map.

Ist edition, 1879 .

*Ang. I.54 King, William Ross. The sportsman and naturalist in Canada; or, Notes on the natural history of the game, game birds, and fish of that country. London. 1866. 1. $8^{\circ}$. Col. front., wdcts., and $5 \mathrm{col}$. plates.

"Fishes," pp. 241-326.

*Ang. 44.50 Kingsley, Charles. Prose idylls, new and old. London. 1873. sm. $8^{\circ}$.

Contents:- "A charm of birds." - Chalk-stream studies; [an essay on angling]. - The fens. - My winter-garden. - From ocean to sea. - North Devon.

Four of the essays were originally published in Fraser's magazine; "Chalkstream studies" appeared in September, 1858 , and also in the author's "Miscellanies," and "New miscellanies."

*Ang. 18.37 Kirkbride, John. The northern angler; or, Fly-fisher's companion. Carlisle, etc. 1837 . I $6^{\circ} .2$ plates.

Westwood and Satchell speak of a frontispiece, but do not mention any other plate.

*Ang. I.43 Klein, Jakob Theodor. Historiæ piscium naturalis promovendæ missus i.-v. 5 pt. in I vol. Gedani. I 740-49. $4^{\circ}$. Port., plates, and vigns.

Contents:-i. De lapillis eorumque numero in craniis piscium, cum præfatione de piscium auditu. Accesserunt Anatome tursionum, Observata in capite raiæ. 1740. - ii. De piscibus per pulmones spirantibus. Accesserunt De dentibus balæenarum et elephantinis, Lapide manati et tiburonis. I74I. iii. De piscibus per branchias occultas spirantibus; cum observationibus circa partes genitales rạæe maris, et ovarium galei. 1742. - iv. De piscibus per branchias apertas spirantibus; cum additamento ad missum tertium. I744. v. De piscibus per branchias apertas spirantibus; cum additionibus ad missus ii., iii., iv. et epistola, De cornu piscis carinæ navis impacto. 1749.

"On ne trouve pas facilement ces 5 parties réunies."-Brunet.

*Ang. I.43 Klein, Jakob Theodor. Mantissa ichtyologica de sono et auditu piscium; sive, Disquisitio rationum, quibus autor epistolæ in Bibliotheca gallica de auditu piscium, omnes pisces mutos surdosque esse, contendit. Lipsiæ. 1746. $4^{\circ}$. pp. (4), 30 .

The letter referred to was published in the Bibliothèque fransoise, tom. xxxvi., pt. 2, p. 273, etc.

*Ang. 39.37 Knox, Arthur Edward. Attumns on the Spey. London. I 872. sm. $8^{\circ}$. Front., plates, and vigns.

Five of the chapters are on salmon fishing, and one on "Tynet burn and its ichthyolites."

"The greater part of this volume is derived from letters written to friends, during several autumns passed at Gordon castle." - Preface. 
Ang. 39.35 Knox, Robert (1791-1862). Fish and fishing in the lone glens of Scotland. With a history of the propagation, growth, and metamorphoses of the salmon. London, etc. I 85.4 sm. $8^{\circ}$. Wdcts.

Severely criticized by H. R. Francis in his "Fly-fisher and his library."

Ang. 18.18.4 Kresz, C. Le pêcheur français; traité de la pêche à la ligne en eau douce. Contenant l'histoire naturelle des poissons, la pêche particulière à chacun d'eux, etc. $2^{\mathrm{e}}$ éd., presque entièrement refaite à neuf et augmentée. Paris. I 830 . sm. I $2^{\circ}$. Port. and 20 plates.

In the Sporting magazine for 1828 and 1829 , are five articles which are translations from this work.

Westwood and Satchell consider it "one of the best French works on the subject."

Ang. 50.2.4(I5) Kumlien, Ludwig, and others. Contributions to the natural history of Arctic America, made in connection with the Howgate polar expedition, 1877-78. Washington. r879. $8^{\circ}$. (U. S. National museum. Bulletin, I 5.) VIII. 39(15) Another copy.

I22.24 The same. Washington. I879. (In SmithSONIAN miscel. coll., I $882,8^{\circ}$, xxiii. 5.)

Ang. 18.81.6 La Blanchère, Henri DE. La pêche en eau douce. Contenant tous les principes de la pêche à la ligne, la description des engins, des poissons, et des eaux où ils se tiennent, la réglementation du droit de pêche, etc. Paris. [1881.] sm. $8^{\circ}$. Wdcts.

*Ang. 47.I La Blanchère, Henri DE. La pêche et les poissons; nouveau dictionnaire général des pêches. Publié sous les auspices de MM. le ministre de la marine et des colonies, le ministre du commerce et de l'agriculture, et le ministre de l'instruction publique. Précédé d'une préface par Aug. Duméril. Illustrations dessinées et coloriées par A. Mesnel, d'après les photographies faites sur nature par l'auteur. Paris. I 868 . 1. $8^{\circ}$. pp. xvi., 859 . Wdcts. and col. plates.

Ang. 38.18 Laing, Samuel (1780-1868). Journal of a residence in Norway during the years 1834,1835 , and 1836 ; made with a view to inquire into the moral and political economy of that country, and the condition of its inhabitants. London. 1836. $8^{\circ}$. Wdcts.

Chapters I, 8 , and 9 contain a few pages on fishing.

24.37 Another copy.

Ang. 38.19 The same. New ed. London. I851. sm. $8^{\circ}$. Wdcts. 
Ang. 18.58.3 Lakeland, R. The Teesdale angler. Barnard Castle. I 858 . I $6^{\circ}$.

" My work, though bearing a local title, is intended as a help and guide to trout fishers generally." - Preface.

La Marre, L. H. DE. Traité général des pesches. I 769, etc. fo. See Duhamel du Monceau, H. L.

Ang. 3.7 Lambert, Osmund. Angling literature in England, and descriptions of fishing by the ancients; with a notice of some books on other piscatorial subjects. London. I88 I. I 6.' pp. (10), 87.

VII. 722 Another copy.

Ang. 18.70 Lambert, Saint-Ange. Nouveau manuel complet du pêcheur-praticien; ou, Les secrets, les mystères, et les ruses de la pêche à la ligne dévoilés et mis à la portée de tout le monde. Nouvelle éd., entièrement refondue, augmentée de pêches nouvelles et de la législation relative à la pêche fluviale. Paris. I $870.24^{\circ}$. Wdcts. and 2 plates. (Manuels-Roret.)

Ang. 49.46.4 Lankester, Edwin Ray. The scientific results of the exhibition. London. I883. $8^{\circ}$. pp. 40. (LONDON, Eng. - International fisheries exhibition, 1883. [The fisheries exhibition literature, iv. 9.])

"In particular, those results of the science of zoölogy which are of importance to the fish industry." - Page 4.

Also another edition.

Ang. 26.10 Lanman, Charles. Adventures of an angler in Canada, Nova Scotia, and the United States. London. I848. $12^{\circ}$. Wdcts.

Published in Philadelphia, 1848 , with the title, "A tour to the river Saguenay in Lower Canada."

The copy described by Westwood and Satchell has a portrait, but there is no mention of one in the list of illustrations.

Ang. 25.I Lanman, Charles. Adventures in the wilds of the United States and British American provinces. Illustrated by the author and Oscar Bessau. With an appendix by Campbell Hardy. 2 vol. Philadelphia. 1856. $8^{\circ}$. Front. and plates.

Contains several chapters on fishing.

Contents:- i. A summer in the wilderness. - A tour to the river Saguenay. - Letters from the Alleghany mountains. - The sources of the Potomac.

ii. A tour to the river Restigouche. - A winter in the South. - Occasional records.

"The several parts of the work were originally published in the journals and periodicals of the day, and subsequently in as many small volumes." Preface.

I5345.25 Another copy. 
*Ang. 27.2 [Lanman, Charles.] Letters from a landscape painter. By the author of "Essays for summer hours." Boston. 1845. sm. $8^{\circ}$.

Contains "Trouting among the Catskills," and "A week in a fishing smack."

I5372.23 Another copy.

*Ang. 44.55 Lanman, Charles. Recollections of curious characters and pleasant places. [Sketches of American life and travel.] Edinburgh. I881. 8\%. Front.

The editor's preface consists of a short sketch of the author, an almost exact reproduction of a biographical notice which appeared in the Literary world, Jan. 15, 1881.

"Salmon-fishing on the river Jacques Cartier," pp. 147-160; "The Potomac fisherman, an autobiographic sketch," pp. 219-227; "Sword-fish fishing," pp. 250-256.

I5346.32 Another copy.

*Ang. 27.I Lanman, Charles. A summer in the wilderness; embracing a canoe voyage up the Mississippi and around Lake Superior. New-York, etc. I847. I $2^{\circ}$.

Contains a few pages on fishing.

Ang. 25.I The same. Plates. (In his Adventures in the I5345.25 wilds of the United States and British American provinces, I $856,8^{\circ}$, i. I-I67.) 2 cop.

4354.30 Lanman, Charles. A tour to the river Saguenay in Lower Canada. Philadelphia. I 848 . sm. $8^{\circ}$.

Published in London, I848, with the title "Adventures of an angler in Canada, Nova Scotia, and the United States."

Ang. 25.I — The same. Plate. (In his Adventures in the I5345.25 wilds of the United States and British American provinces, I $856,8^{\circ}$, i. 169-340.) 2 cop.

Ang. 18.13 [Lascelles, Robert.] Letters on sporting. [In three parts. Angling, shooting, coursing. London. I 8 I 5 ?] $8^{\circ}$. 3 plates.

There is no title-page. Page I has the signature "B."

Two of the plates are dated 1813. The letter on angling is dated Feb. $18 \mathrm{I} \mathrm{I}$, and is signed "Piscator."

Ang. 45.48 [Lathy, Thomas Pike.] The angler; a poem in ten cantos. With proper instructions in the art, rules to choose rods, lines, hooks, receipts. for pastes, \&c. By Piscator. London. 1819. sm. $12^{\circ}$. Port. of Gosden and vigns.

"One of the worst instances of literary appropriation on record. It was palmed off on Gosden, the sporting bookseller, whose portrait 'engraved from a painting by A. Cooper' is prefixed. . . . 'The anglers, in eight dialogues,' attributed to Dr. Scott, is transported bodily into Lathy's book, with a few substitutions and modifications." - Westwood and Satchell.

\section{*Ang. 45.49 The same. London. I 822 . Sm. I $2^{\circ}$. Port. of} Gosden and vigns.

The Ist edition with a new title-page. 
*Ang. 18.18 [Lawrence, John (I756-1836).]. British field sports; embracing practical instructions in shooting, hunting, fishing, \&c., with observations on the breaking and training of dogs and horses, also the management of fowling pieces, and all other sporting implements. By William Henry Scott [pseudon.]. London. 1818. $8^{\circ}$. pp. xii., 6I5. Front., rudits., and 33 plates.

"The fresh water fishery," pp. 570-602.

This copy contains 8 plates published by Pittman, Warwick square, London, in addition to the 34 mentioned in the list on page vii. - On 21 blank leaves inserted at the end, are pasted newspaper cuttings containing sporting notes.

Ang. 60.I Lawson, William, horticulturist. A new orchard \& garden; or, The best way for planting, graffing, and to make any ground good for a rich orchard. With the Country house-wifes garden for herbs of common use, [by Gervase Markham]; also the husbandry of bees. Now the 6th time corrected, and much enlarged. Whereunto is added the Art of propagating plants, [by Simon Harward]. London. 1676. Plan and wdcts. (Appended to [MARKHAM, Gervase]. A way to get wealth, $1676,4^{\circ}$, [vi.].)

"Admissible by stress of courtesy, and for the sake of that "pleasant river with silver streams' that the old writer would fain have in his orchard, and wherein he might 'angle a peckled trout, sleighty eel, or some other dainty fish." " - Westwood and Satchell.

V. 4398 Another copy.

Ang. 49.46.3 Lee, Henry (1 826-1888). Sea fables explained. London. I 883. $8^{\circ}$. Front. and wdcts. (London, Eng.International fisheries cxhibition, I 883. [The fisheries exhibition literature, iii. 3.])

Contents:- The mermaid. - The Lernean hydra. - Scylla and Charybdis. —The "spouting" of whales. - The "sailing" of the nautilus. — Barnacle geese; goose barnacles.

Also another edition.

Ang. 49.46.3 Lee, Henry (I 826-1888). Sea monsters unmasked. London. 1883. 8\%. Front. and wdcts. (London, Eng. - International fisheries exhibition, I883. [The fisheriesexhibition literature, iii. 4.])

Contents:- The kraken. - The great sea serpent.

The author considers the great cuttlefishes " as the living representatives of the kraken."

Also another edition.

*Ang. 1.30 [Leech, John (1817-1864).] Mr. Briggs \& his doings. [Fishing. A series of copper-plate etchings.] London. [1860.] obl. $4^{\circ}$. I 2 col. plates.

"Enlarged and tinted reproductions of the drawings which originally appeared in Punch. Copies are now scarce and dear." - Westwood and Satchell. 
Le Fèvre, Jean, translator. La vieille. 1861. $8^{\circ}$. See Fournival, Richard DE.

Ang. 49.46.8 Leith, J. M. The legislation at present applicable to the salmon fisheries in Scotland, and the best means of improving it. Prize essay. London. 1884. $8^{\circ}$. pp.7 I. (LoNDON, Eng. - International fisheries exhibition, I 883. [The fisheries exhibition literature, viii. 3.])

Also another edition.

Ang. 18.57.4 Lennox, Lord William (Pitt). Merrie England; its sports and pastimes. London. 1857. $8^{\circ}$.

"Fishing," pp. 212-232; "Sea fishing," pp. 348-36r.

Ang. 18.62.7 Lennox, Lord William (Pitt): Recreations of a sportsman. 2 vol. London. I862. sm. $8^{\circ}$. Fronts.

The work is divided into twelve chapters, describing sports for each month of the year. Most of them contain a few pages on fishing.

Ang. 3.12 Lenox library, New York (City). The Waltonian collection; books upon angling, birds, fishes, hunting, etc. pp. 56. (In its Contributions to a catalogue of the library, I $893,4^{\circ}$, vii.)

\section{A 36.13 Another copy.}

Letters from a landscape painter. ' $1845 . \quad 8^{\circ}$. See [Lanman, Charles].

Letters on sporting. [1815?] $8^{\circ}$. See [Lascelles, Robert].

Ang. 49.46.4 Levi, Leone. The economic condition of fishermen. London. 1883. 8\%. pp. 48. Diagr. (London, Eng. -International fisheries exhibition, I883. [The fisheries exhibition literature, iv. 5.])

Also another edition.

*Ang. 45.5I Liddell, Robert (b. I 808). The lay of the last angler ; in four cantos. To which is added Jack's dangers and deliverances. With illustrations from original etchings by the author. Kelso. 1884. sm. $8^{\circ}$. Port. and plates.

"First printed for circulation only among private friends."

The first canto originally appeared in 1867 , the second in 1870 , the third in I 874 .

Ang. 39.22 Lister, J. Lupton. Sea fishing at Tenby. Tenby. [1879?] I $6^{\circ}$. pp. (6), 68.

The preface is dated June, 1878 .

*Ang. 18.82.3 Little, G. Anglers' annual; comprising articles and practical information on all matters relating to fish and fishing, by the ablest writers. An almanack with notes of special interest is added. London. [I882.] sm. $4^{\circ}$. Portrs. and zudcts.

Contains several portraits of "gentlemen eminent in the fishing world," with short sketches of their lives. 
*Ang. 22.2 Little, G. The unique fly book. [London. 188-?] I $6^{\circ}$. pp. (2 I ). Col. illustr.

There is no title-page. The work consists of 76 illustrations of flies, with brief directions for the use of each.

Ang. 18.79 Little, Giles, \& co. G. Little \& co., fishing rod \& tackle manufacturers and fly dressers. [Catalogue of fishing rods and tackle. - The angler's instructor, \&c.] London. I879. 16\%. pp. 63. Wdcts.

Some of the information for anglers is taken from the blue book of the Thames angling preservation society.

Ang. 22.16 Little, Giles, \& co. Wholesale illustrated price list, Giles Little \& co., city fishing rod \& tackle works. London. [187-?] $8^{\circ}$. pp. 30. Wdcts. Lithographed.

Ang. 38.23 Lloyd, Llewellyn. Field sports of the north of Europe; comprised in a personal narrative of a residence in Sweden and Norway, in the years 1827-28. 2 vol. London. I830. $8^{\circ}$. Map, zudcts., plans, and plates.

Imperfect:- frontispiece, map, and plate in vol. i., and frontispiece in vol. ii., wanting.

Chapters 12, 17, 18, 21, 22 of vol. i., and chapter 5 of vol. ii. contain pages on fishing.

*Ang. 46.3 Lloyd, Llewellyn. The game birds and wild fowl of Sweden and Norway; with an account of the seals and saltwater fishes of those countries. 2d ed. London. I 867. 1. $8^{\circ}$. pp. xx., 599. Front., map, plates, and wdcts.

"Scandinavian salt-water fishes," pp. $458-580$.

The frontispiece and all but four of the plates are chromo-lithographs, and six of them contain illustrations of fishes.

*Ang. 38.26 Lloyd, Llewellyn. Scandinavian adventures during a residence of upwards of twenty years. - Representing sporting incidents, and subjects of natural history, and devices for entrapping wild animals; with some account of the northern fauna. 2 vol. London. I854. 1. $8^{\circ}$. Fronts., map, wdcts., and to plates.

Vol. ii. is " 2 d ed."

Chapters $3^{-1} 3$ of vol. i. are on fishing.

Ang. 39.34 Lochleven angler (The). By an ex-president of the Kinross-shire fishing-club. Kinross, etc. I 874 . I $6^{\circ}$. Front., map, and zodcts.

"The greater portion of the subject-matter appeared originally in the Kinross-shire advertiser."

*Ang. 39.17 [Locke, James.] Tweed and Don; or, Recollections and reflections of an angler for the last fifty years. Edinburgh, etc. $1860.16^{\circ}$. Front. and wdcts.

Ang. 50.13 Lockington, William Neale. Report upon the edible fishes of the Pacific coast, U. S. A.. (In California - Commissioners of fisheries. Report for $\mathrm{I} 880,8^{\circ}$, pp. I6-66.) 
Ang. 50.13 Lockington, William Neale. Report upon the food fishes of San Francisco. (In CALIFornia - Commissioners of fisheries. Report for $\mathrm{I} 878 / 79,8^{\circ}$, pp. I 7-58.)

London angler's book (The). I 834. I $2^{\circ}$. See Baddeley, John.

VIII. 39I London, Eng. - International fisheries exhibition, I883. The fisheries exhibition literature. I 4 vol. London. I 884 . $8^{\circ}$

\section{Handbooks.}

i. Walpole, Spencer. The British fish trade.-Kent, W. S. Marine and freshwater fishes of the British Islands. - Pollock, Sir Frederick, $3 d$ bart. The fishery laws. - Holdsworth, E. W. H. Apparatus for fishing. - Mitchell, W. S. The place of fish in a hard-working diet, with notes on the use of fish in former times. - Adams, W. M. A popular history of the fisheries and fishermen of all countries from the earliest times.

ii. DAy, Francis. Fish culture.-Howes, G. B. Zoölogy and food fishes. - Bertram, J. G. The unappreciated fisher folk: their round of life and labour. - Fryer, C. E. The salmon fisheries.-Senior, William. Angling in Great Britain. - DAY, Francis. Indian fish and fishing.

iii. Robinson, Philip. Fishes of fancy: their place in myth, fable, fairytale, and folk-lore. With notices of the fishes of legendary art, astronomy, and heraldry. - Wheeldon, J. P. Angling clubs and preservation societies of London and the provinces. - LEe, Henry. Sea fables explained. Sea monsters unmasked. - Wheeldon, J. P. Practical lessons in the gentle craft. - MANLEY, J. J. Literature of sea and river fishing.

\section{Conferences.}

iv. Huxley, T. H. Inaugural address.-Alfred ERnest Albert, ist duke of Edinburgh, son of Victoria 1 . of Gr. Brit. Notes on the sea fisheries and fishing population of the United Kingdom.-Shaw-Lefevre, George. Principles of fishery legislation.-WALPOLE, Spencer. Fish transport and fish markets. - Levi, Leone. The economic condition of fishermen. Fryer, C. E. A national fisheries society. - Kennett-Barrington, Sir V. H. B. River pollution by refuse from manufactories and mines; with some remedies proposed. - Practical Fishermen's CONGRess, London, 1883. Destruction of immature fish, etc.-LANkester, E. R. The scientific results of the exhibition.

v. Goode, G. B. A review of the fishery industries of the United States, and the work of the United States fish commission.-Hubrecht, A. A. W. Oyster culture and oyster fisheries in the Netherlands. - JonCAs, L. Z. The fisheries of Canada. - Camprell, J. D. The fisheries of China.-Okoshi, Narinori. A sketch of the fisheries of Japin.- ShEA, Sir Ambrose. Newfoundland: its fisheries and general resources.-SMITT, F. A. The Swedish fisheries. - Wallem, F. M. Notes on the fish supply of Norway. - RaMSAY, E. P. Notes on the food fishes and edible mollusca of New South Wales, etc. - García SolÁ, Francisco. The fisheries of Spain. - AdDERLEy, Sir A. J. The fisheries of the Bahamas. - Moloney, Sir C. A. West African fisheries, with particular reference to the Gold Coast colony.

vi. Huxley, T. H. Fish diseases. - Maitland, Sir J. R. G., $4^{\text {th }}$ bart. The culture of salmonidx and the acclimatization of fish. - DuFF, R. W. The herring fisheries of Scotland.-Corvish, Thomas. Mackerel and pilchard fisheries. - Milne-Home, David. Salmon and salmon fisheries. Marston, R. B. Coarse fish culture.-Coвbold, T. S. The destruction of fish and other aquatic animals by internal parasites. - DAY, Francis. The food of fishes.-HARDING, C. W. Molluscs, mussels, whelks, etc., used for food or bait. - KENT, W. S. The artificial culture of lobsters. - CoRNISH, Thomas. Crustaceans. 
vii. Thompson, Sir Henry. Fish as food. - Massey-Mainwaring, W. F. B. The preservation of fish life in rivers by the exclusion of town sewage. - Bloomfield, J. C. The fisheries of Ireland. - Walsh, R. F. Improved facilities for the capture, economic transmission, and distribution of sea fishes, etc.-Temple, Capl. Seal fisheries. - Scotr, R. H. Storm warnings. Roper, Richard. Saving life at sea. - Kilbourn, J. K. Fish preservation and refrigeration.-García Soldí, Francisco. The basis for legislation on fishery questions. - Howitz, D. Forest protection and tree culture on water frontages, etc. - Mundahl, C. M. Line fishing.-Ansell, A. W. Trawling.

\section{Prize essays.}

viii. DAy, Francis. The commercial sea fishes of Great Britain. - MoRRIS, C. W. The effect of the existung national and international laws for the regulation and protection of deep sea fisheries; with suggestions for improvements of said laws. - Leith, J. M. Salmon legislation in Scotland: the legislation at present applicable to the salmon fisheries in Scotland and the best means of improving it.

ix. WiLcocks, J. C. Improved fishery harbour accommodation for Great Britain and Ireland. - DE CAUX, J. W. The best system of life insurance for fishermen, and of insuring boats, gear, nets, etc. - FrYer, C. E. The relations of the state with fishermen and fisheries, including all matters dealing with their protection and regulation.-Chater, F. J. T. The relations of the state with fishermen and fisheries, including all matters dcaling with their protection and regulation. - BEAUjon, Anthony. The history of Dutch sea fisheries: their progress, decline, and revival, especially in connection with the legislation on fisheries in earlier and later times.

x. Houghton, William. The natural history of commercial sea fishes of Great Britain and Ireland. - BLAKE, H. P. Improved facilities for the capture, economic transmission, and distribution of sea fishes. - CAYLEY, J. J., and BRIDGMan, H. H. A central wholesale fish market for London.-Smith, W. A. The best appliances and methods of breaking the force of the sea at the entrance to harbours and elsewhere.

xi. Stirling, J. The propagation of the salmonidx.-Andrews, T. The propagation of the salmonidx. - Chambers, W. O. The propagation of the salmonidæ. - Clark, John. The salmon disease. - Smith, W. A. Salmon disease: its cause and prevention.-Marston, R. B. The cultivation of freshwater fish other than salmonidæ. - Chambers, W. O. The propagation of freshwater fish excluding salmonidæ.-HOGarTH, Ronald. The herring fishery. - Munro, R. J. The herring fisheries.-Green, H. J. The herring fisheries. - MiLv, W. S. The Scotch east coast, Orkney and Shetland, Lewis and Barra herring fishing.-Houghton, William. The natural history and cultivation of the sole.-Anson, C. V., and Willett, E. H. Oyster culture. -- HoEk, P. P. C. Oyster culture.-CARR, T. F. R. The best means of increasing the supply of mussels and other molluscs, etc. Wilcocks, J. C. The best means of increasing the supply of mussels and other molluscs, etc. - Chambers, W. O. The introduction and acclimatisation of foreign fish. - Sim, G. The food of fishes, etc. - WATt, W. The currents, temperatures, and other physical conditions of the sea in relation to fish.--Skinner, J. Angling clubs.

\section{Miscellaneous.}

xii. Official catalogue. - Awards of the international juries.

xiii. Walpole, Spencer. Official report on the exhibition.- Statement of receipts and disbursements. - Gooch, W. D. Special report on the electric lighting of the exhibition. - Ceremonial at opening of exhibition and addresses at closing. - Report of executive committee to general committee. - Statistical tables. - Condensed reports on the condition of the fishing industry in the United Kingdom and abroad, used in the first instance in the official catalogue.

xiv. Analytical index. 
Ang. 49.46, etc. London, Eng. - International fisheries exhibition, I883. [The fisheries exhibition literature. Vol. i.-xi.] London. I883-84. $8^{\circ}$.

Contains the papers separately issued, with special title-pages and pagination. The following numbers are wanting: - vol. iii. no. 5 ; v. 7, 10; vi. 6 ; ix. 1,$2 ; x .3,4$; xi. 12. At the end of vol. vii. is bound an extra number: "Freshwater fishing in Great Britain other than trout or salmon; by J. P. Wheeldon." There is also a second copy of vi. 2; with slight changes.

Ang. 12.29 London, Eng. - Walton and Cotton club. Rules and regulations of the club, instituted I9th March, I8I7; revised 8th April, I 840. London. I 840. sm. $8^{\circ}$. pp. (24). Front. and wdcts.

Londons blame, if not its shame. I65I. $4^{\circ}$. See Jenner, Thomas.

Ang. 49.30 Longfield, Robert. The fishery laws of Ireland. [With appendix, containing "Fishery acts." $]$ Dublin. I 863. I $2^{\circ}$. Table and $m a p$.

The table shows the close seasons for salmon and trout in the different districts of Ireland.

Ang. 32.7 Lord, John Keast. At home in the wilderness; what to do there and how to do it. A handbook for travellers and emigrants. $3 \mathrm{~d}$ ed. London. I876. sm. $8^{\circ}$. Port. and wdcts.

Chapter 9 contains " Fishing gear" and " A good day's sport;" chapter 16 "Catching and curing white-fish and salmon."

Ist edition, 1867 .

Ang. 26.9 Lord, John Keast: The naturalist in Vancouver island and British Columbia. [With an appendix.] 2 vol. London. 1866. $8^{\circ}$. Fronts., plates, and vigns.

Chapters 2-7 of vol. i. treat of fishes and fishing.

V. 76 Another copy.

Ang. 46.19 Lord, William Barry. Crab, shrimp, and lobster lore, gathered amongst the rocks, at the sea-shore, by the riverside, and in the forest. London. 1867. I $6^{\circ}$. Front. and wdcts.

Contents:- Crabs. - Shrimps and prawns. - Lobsters. - River crayfish.

Ang. 18.62.2 Lord, William Barry. Sea fish \& how to catch them. London. [I87-?] I $6^{\circ}$. Wdcts.

The title-page is illustrated.

Ist edition, I862, without date.

*Ang. 38.7 Lorgh, Cairn, pseudon. A ten-pound tour; with sketches of travel and sport [in the Ardennes]. London. [1873.] $16^{\circ}$.

Cont ains "Spring trout-fishing in the Ardennes," reprinted from the Field.

Ang. 49.43 Low, Alexander. Angling associations; with code of rules for their management. (In HERBERT, David, editor. Fish and fisheries, I $883,8^{\circ}$, pp. 262-274.) 
Io John Bartlett, who dent a ripound brofletroal.

Fit for an Abbot of Theleme, For the whop Carsinale' College, or The Pope himself \& see in Cream Before his lenten vision gleam, The his there, - the sagoologer!

tho precious flanks with stars bispreats, both to bim in lastly! Th friend 3 whom sack gifts are vast, For him shale bumpers pule $L$ spent, Its health! \&. huck his fast ally! 

I dee him trace to saquars brook Amid the forst mppteries.

shere at their braiths sy aspens look, Or where, sith hany a gurghing book If Crooss it vorituma histories.

I ve laefohad a kn=flect lend Thai tremelons, sout ircifiths, To muorth dark pool, L Crintchig beal, (the. Stew him, thrue, as twere a friend, With amorrue dolicatude!'):

I de him stef bitt Caution hue, loff as if sho sitt moccosins, Gion as in Chusch, - o who plies you. brat braft, is Saff as in a pew From all ons Common stock s' sins 

The nerving fly I dee him Cast, That as a roonleal gallo as soft, A flask! a whirl! 'he has him fast! be tyros, - how that struggle last Corpus a appalls us of k!

thifhtters he; Calm as the Shy hoots on our tragicomeness, This way that he leto him ff, A Sunbeam shuttle, them to bis bLanch him with Cool aplomb er at Eco. 

Th frind tho gave ous bowis anch gust, Life: Carr, may the o'erstep th lalf, trad ohem bchel hooks him, as he must. trill to il freath, as I trot. tho She toalmes biste his sfitaph!

Oh. borr beneath the Fiskes' siga, Of Arsteflations happinot.

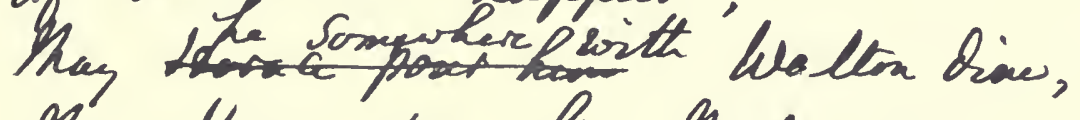
Thay Herace pous him thapis sine. thotburas Seoteh briak, the rafpiest! tho solen they Come has ber? I serigh trit how he uno the taleinto hio, the tribcale in the scall hill lay. (g) trat hat seales) o torle shingh the sorng sis of the bulanas.

Hekarerll. Slmovor: 19 th hly, 1885. 

Ang. 47.13 Lowe, Richard Thomas. A history of the fishes of Madeira. With original figures from nature of all the species, by C. E. C. Norton and M. Young. London. I843-60. 1. $8^{\circ}$. 28 plates.

Most of the plates are colored.

The signature reads "vol. i."

Ang. I.57 Lowell, James Russell. To Mr. John Bartlett, who had sent me a seven-pound trout. [Cambridge. 18-.] $4^{\circ}$. pp. (2).

'Signed " Elmwood, I 858 ."

A fac-simile of the original manuscript is inserted in this catalogue.

viii. $47-48$.)

Ang. 22.10 Lowth, W. S. Angling, angling dodges, and match fishing. Newport, Hull [Eng. 18-.] $8^{\circ}$. pp. (2), $5^{8}+$. Wdcts.

"These few pages have been written, set up in type, and bound by an amateur."

Lugger, Otto. List of fishes of Maryland. 1876, etc. 8. See Uhler, P. R., and Lugger, Otto.

M., G. Cheap and good husbandry. See [Markham, Gervase]. Cheap and good husbandry. 1676. $4^{\circ}$. Note.

M., G. A way to get wealth. I676. $4^{\circ}$. See [Markham, Gervase].

*Ang. I.29 M'Alpine, Daniel. Zoölogical atlas, including comparative anatomy. With practical directions and explanatory text. [i.] Edinburgh, etc. I88I. obl. $4^{\circ} .24 \mathrm{col}$. plates.

Contents:- $[$ i. $]$ Vertebrata.

Consists of plates, with descriptions. Five of them are devoted to the skate, and four to the cod.

Ang. 49.37 [Mackenzie, Murdo.] View of the present state of the salmon fishery of Scotland, with observations on the nature, habits, and instincts of the salmon race, and on Scotch law and Scotch justice. By a salmon fisher. London. [1830?] $8^{\circ}$. Plate.

Ang. 49.37.2 Mackenzie, Murdo. View of the salmon fishery of Scotland, with observations on the nature, habits, and instincts of the salmon, and on the law as affecting the rights of parties, etc. With appendix. Edinburgh, etc. 1860. $8^{\circ}$. son.

The appendix, entitled "Do grilse grow to be salmon?" is by the author's 
*Ang. 18.06 Mackintosh, Alexander. The Driffield angler; in two parts. Containing descriptions of the different kinds of fresh water fish, and the best methods of taking them. To which are added instructions for shooting, with rules for the breeding and management of pointers and spaniels, a description of the forest of Blair, also a short treatise on coursing. Gainsborough. [1806.] I $2^{\circ}$. Front.

"Although I have given this work the title of the 'Driffield angler,' the rules it contains will equally apply to other northern rivers. "-Advertisement.

Ang. 45.53 McLellan, Isaac. Poems of the rod and gun; or, Sports by flood and field. Edited, with a memoir of the author, by Will Wildwood [F. E. Pond]. New York. I 886. sm. $8^{\circ}$. Front.

"Memoir," pp. II-16.

AL 2422.8.20 Another copy.

Ang. 50.48 Maine-Commissioners of fisheries. Reports of the commissioners for $1867-1879$. I2 pam. in I vol. Augusta. I 869-79. $8^{\circ}$. Front. and plates.

For later reports, see the "Report of the commissioners of fisheries and game for 1880 ," etc.

Ang. 50.48 Maine-Commissioners of fisheries and game. Report of the commissioners for I880-1884. 5 pam. Augusta. I 880-84. $8^{\circ}$.

For earlier reports, see the "Reports of the commissioners of fisheries for 1867," etc.

Mainwaring, William Frederick Barton Massey. See Massey-Mainwaring.

Ang. 49.46.6 Maitland, Sir James Ramsay Gibson, 4th bart. On the culture of salmonidae and the acclimatization of fish. London. I 883. 8\%. pp. 36. (LoNDON, Eng.-International fisheries exhibition, I883. [The fisheries exhibition literature, vi. 2.])

Ang. 49.46.6 Another copy, with slight changes.

Also another edition.

*Ang. 18.80.2 Manchester, Eng. - Anglers' association. Anglers' evenings; papers by members of the association. [Series I]-3. Manchester, etc. 1880-94. $8^{\circ}$. Fronts., plates, and wdcts.

"Bibliography of angling," [i.] 243-276.

The frontispiece and three of the plates of the second series, are from carbon drawings by George Sheffield. The third series contains ten angling songs.

*Ang. 18.80.3 The same. 2d ed. [Series I.] Manchester, etc. 1883. $8^{\circ}$. Vigns.

"Bibliography of angling," [i.] 243-276. 
Ang. 49.46.3 Manley, John Jackson. Literature of sea and river Ang. 3.10 fishing. London. I883. 8\%. (London, Eng.-International fisheries exhibition, 1883 . [The fisheries exhibition literature, iii. 6.]) 2 cop.

Also another edition.

*Ang. 18.77.2 Manley, John Jackson. Notes on fish and fishing. London. I 877 . sm. $8^{\circ}$. Wdcts.

"The literature of fishing," pp. 32-70.

Osmund Lambert in his "Angling literature in England" says, "Mr. Manley is one of our leading authorities on angling literature."

*Ang. I8.31.5 [March, J.] The jolly angler; or, Water side companion. Containing an account of all the best places for angling, as well as the tackle, baits, \& other requisites to form an expert angler; with a description of making artificial flies, \&c. [5th ed.] London. [184-.] $12^{\circ}$. Front. and wdits.

The introduction is dated 1842 , which is the date of the fourth edition.

Ang. 60.I [Markham, Gervase.] Cheap and good husbandry; for the well-ordering of all beasts and fowls, and for the general cure of their diseases. With the use and profit of bees, the manner of fish-ponds, and the taking of all sorts of fish. Newly corrected and enlarged with many excellent additions. I 3 th ed. London. 1676. Plan. (In his Way to get wealth, $1676,4^{\circ},[i$.$] .)$

The "epistle dedicatory" is signed "G. M."

"Of fish and fish-ponds," pp. 142-146.

The plan is entitled "A platform for ponds."

\section{4398 Another copy.}

*Ang. I7.12 [Markham, Gervase.] A compleat and experienc'd angler, in two parts; or, The anglers vade mecum. Shewing the best way to make fishing-rods, lines, and other tackle, and how to find the haunts of fish, and take them with all sorts of baits. The second part contains directions to take fowl, and to order singing-birds, hawks, hares, etc. [London. cir. I 7I2.] $24^{\circ}$. Wilcts.

Intperfect: - frontispiece and first title-page wanting.

This is an edition of Markham's "Young sportsman's instructor." The missing title-page reads "The young sportsman's delight and instructor in angling, fowling, hawking, hunting, ordering singing birds, hawks, etc., and how to cure them. By G. M." The book is very rare.

Ang. 60.I Markham, Gervase. Country contentments; or, The husbandmans recreations. Containing the wholesome experience in which any ought to recreate himself, after the toyl of more serious business. As hunting, hawking, coursing, etc., the whole art of angling, and the use of the fighting cock. IIth ed., newly corrected, enlarged, and 
adorned with many excellent additions. London. 1675 . pp. (4), $92+$. (In his Way to get wealth, I676, $4^{\circ}$, [ii.].)

"The whole art of angling; as it was written in a small treatise in rime, and now for the better understanding of the reader put into prose, and adorned and enlarged," pp. 47-8o.

The editions of I6I I and I6I5 do not contain the treatise on angling, in which long extracts from the "Secrets of angling," by John Dennys, are given in prose. It was also published by Markham in his "Pleasures of princes."

V. 4398 Another copy.

Imperfect: - table of contents wanting.

Ang. 60.I [Markham, Gervase.] The country house-wife's garden; containing rules for herbs and seeds of common use, with the husbandry of bees. Published with secrets very necessary for every house-wife, as also divers new knots for gardens. London. I676. Wdcts. ( In LAwson, William. A new orchard \& garden, I676, $4^{\circ}$, pp. 57-82.)

V. 4398 Ang. 60.I

V. 4398

Ang. 60.1

V. 4398 Ang. 60.1

\section{Another copy.}

Markham, Gervase. The English house-wife ; containg [sic] the inward and outward vertues which ought to be in a compleat woman. As her skill in physick, chirurgery, cookery, the knowledge of dayries, of brewing, baking, and all other things belonging to an houshold. Now the 8th time much augmented, purged, and made most profitable for all men. London. 1675. Diagrs. ( $\mathrm{In}$ his Way to get wealth, $1676,4^{\circ}$, [iii.].)

\section{Another copy.}

Markham, Gervase. Farewel to husbandry; or, The enriching of all sorts of barren and sterile grounds to be as fruitful as the best grounds. Now the roth time revis'd, corrected, and amended, with many new additions and cheap experiments. London. 1676. Wicts. (In his Way to get wealth, $1676,4^{\circ},[\mathrm{v}$.$] .)$

"Grounds for fish-ponds," pp. 42-43.

Another copy.

Markham, Gervase. The inrichment of the weald of Kent; or, A direction to the husbandman for the true ordering, manuring, and inriching of all the grounds within the wealds of Kent and Sussex, and may generally serve for all the grounds in England of that nature. Painfully gathered by a man of great eminence and worth, but revised, enlarged, and corrected with the consent and by conference with the first author. London. 1675. pp. (4), 19. (In his Way to get wealth, $1676,4^{\circ}$, [iv.].)

\section{4398 Another copy.}


*Ang. 16.14 [Markham, Gervase.] The pleasures of princes, or, Good mens recreations. Contayning a discourse of the generall art of fishing, with the angle, or otherwise, and of all the hidden secrets belonging thereunto; with the choyce, ordring, breeding, and dyetting of the fighting cock, being a worke never in that nature handled by any former author. London. I635. sm. $4^{\circ}$. pp. (2), 54.

This forms the second part of the second book of his "English husbandman." The "art of fishing" was also used by Markham in his "Country contentments;" it contains many extracts rendered into prose, from the "Secrets of angling" by John Dennys.

Ang. 6o.I [Markham, Gervase.] A way to get wealth; containing six principal vocations or callings, in which every good husband or house-wife may lawfully imploy themselves. The first five books gathered by G. M., the last by W. L. The I 3 th time corrected and augmented by the author. London. 1676. sm. $4^{\circ}$. pp. (732). Plans and wdcts.

Each part has a special title-page and separate paging.

Contents:- Cheap and good husbandry. I $3^{\text {th }}$ ed. I676. - Country contentments; or, The husbandmans recreations. IIth ed. 1675. - The English house-wife. 1675. - The inrichment of the weald of Kent. 1675. Farewel to husbandry. I676. - A new orchard \& garden; by William Law. son. 1676 .

\section{4398 Another copy.}

Imperfect: - "Table of the Country contentments," 3 pp., wanting.

Ang. 45.62 Markham, Gervase. The young angler's instructor. ( In The ANGLER'S garland and fisher's delight, I $871,4^{\circ}$, pp. I 2-19.)

An extract from his work published about 1597 with the title, "The young sportsman's instructor in angling, fowling, hawking, hunting, ordering singing birds, hawks, poultry, coneys, hares, and dogs, and how to cure them." The volume, according to Westwood and Satchell, measures $2 \frac{1}{2}$ inches by $1 \frac{3}{4}$. This fragment contains fac-similes of the title-page and frontispiece of the original edition, which, Pearson says, is " excessively rare."

Ang. 50.90 Marsh, George Perkins. Report made under authority of the legislature of Vermont, on the artificial propagation of fish. [With an appendix.] Burlington. I $857.8^{\circ}$. "Artificial fish-breeding; abridged from an essay by Karl Vogt," [i.] 2252. - "Pisciculture;" by Jules Haime, [ii.] 10-40.

47.43 Marshall, Rev. Charles. A plain and easy introduction to the knowledge and practice of gardening, with hints on fish-ponds. $3 \mathrm{~d}$ ed., enlarged. London. 1800 . I $6^{\circ}$.

Ang. 60.6 The same. 4th ed., enlarged and improved. [London.] I $805.5 \mathrm{sm} .12^{\circ}$.

"Hints on the method of managing pond-fish," pp. 413-417.

"Mr. Marshall was favoured with this paper by an eminent literary character in the church, ' a member of the free agricultural society at St. Petersburg. " "- Page 4 I 7. 
*Ang. 39.2I [Marston, Edward.] An amateur angler's days in Dove Dale; or, How I spent my three weeks' holiday, July $24-$ Aug. I4, I884. London. I884. I $6^{\circ}$. pp. viii., 88. Illustr. title-page.

"Only roo copies printed."

The "prefatory note" is signed "E. M."

The illustrated title-page is on India paper, mounted.

*Ang. 39.4 [Marston, Edward.] Fresh woods and pastures new. By the author of "An amateur angler's days in Dove Dale," etc. London. I $887.8^{\circ}$.

The "introductory nole" is signed " $\mathrm{E}$. M."

Contains accounts of fishing in the Teme, the Lugg, and other streams, given in the form of letters, many of which were written for the Fishing gazetle.

VIII. 39I(vi) Marston, Robert Bright. Coarse fish culture. Wdcts. (In London, Eng. - International fisheries exhibition, I883. The fisheries exhibition literature, I884, $8^{\circ}$, vi. 205-244.)

Ang. 49.46.II Marston, Robert Bright. The cultivation of freshwater fish other than salmonidæ. Prize essay. London. I 884. $8^{\circ}$. pp. Io. Plate. (LoNDON, Eng.-International fisheries exhibition, I883. [The fisheries exhibition literature, xi. 6.])

Also another edition.

Ang. 12.30 Marston, Robert Bright. Walton, and some earlier writers on fish and fishing. London. I $894 . \mathrm{sm} .8^{\circ}$. (The BOOK-LOVER's library.)

"Deals at greater length with the principal works referred to than is the case in any other single volume." - Introductory.

The "earlier writers" mentioned are Juliana Barnes, Leonard Mascall, John Dennys, Gervase Markham, Thomas Barker, etc.

Ang. 18.54.9 Martin, James, angler. The angler's guide; the most complete and practical ever written. With a minute description of tackle, baits, etc., and all the places for angling within twenty miles of London. To which is added a laughable story, entitled "The three jolly anglers." London. I 854. i $6^{\circ}$. Front.

*Ang. 18.82.4 Martin, John William. Float fishing and spinning in the Nottingham style; being a treatise on the so-called coarse fishes, with instructions for their capture. Including a chapter on pike fishing. London. $1882 . \mathrm{sm} .8^{\circ}$. 8 plates.

Plate $\mathrm{I}$ is used as a frontispiece.

This work describes the style of angling employed on the Trent. "The Trent angler is supposed to be the most scientific of bottom fishermen in the kingdom." - Preface.

Martingale, pseudon. See White, - 
Ang. 50.49 Maryland-Commissioner of fishcries. Report, 18761878. 3 pam. in I vol. Annapolis, etc. I876-78. $8^{\circ}$. Fronts., plates, map, etc.

Ang. I5.90 Mascall, Lconard. A booke of fishing with hooke and line. Reprinted from the edition of 1590 , with preface and glossary by Thomas Satchcll. London. I $884 . \mathrm{sm} .4^{\circ}$. pp. x., (2), 52. Wdcts.

This is a reprint of the first part of Mascall's work whose full title reads: "A booke of fishing with hooke \& line, and of all other instruments thereunto belonging. Another of sundrie engines and trapps to take polecats, etc. Made by L. M."

"A compilation made by a practical angler from the "Treatyse of fyshynge wyth an angle' [of Juliana Barnes], from 'L'agriculture et maison rustique ' of Charles Estienne, and other sources." - Preface.

On the first fly-leaf is the autograph of the editor.

Ang. 50.50 Massachusetts - Commissioners for the artificial propagation of fish. Report of commissioners appointed under resolve of 1856 , chap. 58 , concerning the artificial propagation of fish. [With other documents. Boston. 1857.] 8. pp. 54. (Senate, no. 193.)

“Pisciculture," by Jules Haime, pp. 19-54.

Ang. 50.50 Massachusetts - Commissioners of fisheries. [2d-22d annual] report of the commissioners for [1867]-1887 (in 2 vol.). Boston. I 868-88. $8^{\circ}$. Front., maps, plates, etc.

The $5^{\text {th-2oth }}$ reports have the title, "Report of the commissioners on inland fisheries;" that for 1886 is called "Report of the fish and game commissioners," and that for I887, "Report of the commissioners on inland fisheries and game." The 6th report contains a collection of the laws of Massachusetts relating to inland fisheries, $1623-1871$.

Another set, containing the ist report, in the pamphlet files.

Ang. 46.25 Massachusetts - Zoölogical and botanical survey. Report on the invertebrata of Massachusetts, comprising the mollusca, crustacea, annelida, and radiata; [by A. A. Gould]. Cambridge. I84I. $8^{\circ}$. Widcts. and 15 plates.

Chiefly devoted to mollusca.

The illustrations were drawn from nature by the author.

46.75 Another copy.

46.80 The same. 2d ed., comprising the mollusca. By A. A. Gould; edited by W. G. Binney. Boston. 1870. $8^{\circ}$. Wdcts. and 12 plates.

The illustrations are entirely new. All but one of the plates are colored.

Ang. 46.26 Massachusetts - Zoölogical and botanical survey. Reports on the fishes, reptiles, and birds of Massachusetts. Boston. I $839 . \quad 8^{\circ} .4$ plates.

Contents:- STORER, D. H. Reports on the ichthyology and herpetology of Massachusetts. - PEABody, W. B. O. A report on the ornithology of Massachusetts. 
Ang. 18.52.3 Massas, Charles DE. Le pêcheur à la mouche artifi-

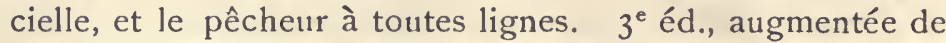
plusieurs chapitres. Paris. [186-.] $18^{\circ}$. Port. and wdcts.

Ist edition, 1852. A " 2 e éd., augmentée de plusieurs chapitres;" appeared in 1861 .

Ang. 49.46.7 Massey-Mainwaring, William Frederick Barton. The preservation of fish life in rivers by the exclusion of town sewage. London. I883. $8^{\circ}$. pp. 37. (London, Eng. - International fisheries exhibition, i883. [The fisheries exhibition literature, vii. 2.])

Also another edition.

Ang. 32.8 Mast, Isaac. The gun, rod, and saddle; or, Nine months in California. Philadelphia. 1875. $16^{\circ}$. Front. and plates.

Ang. 50.63 Mather, Fred. Memoranda relating to Adirondack fishes, with descriptions of new species; from researches made in I882. Albany. I886. $8^{\circ}$. pp. (2), 56. Plate.

From the appendix to the 12 th report on the survey of the Adirondack region of New York. "Printed in advance of the report."

Ang. 50.63 The same. [Revised to 1889.] Plate. (Appended to NEW YORK (State) - Commissioners of fisheries. I 8 th report, I $890,8^{\circ}$, pp. 124-182.)

Ang. 49.43 Matthey, Albert. Sur la pêche de la truite à Vallorbes, Suisse, ct. Vaud. 3 plates. (In HERBERT, David, editor. Fish and fisheries, $1883,8^{\circ}$, pp. 207-225.)

Maxims and hints for an angler. I 868 . $12^{\circ}$. See [Penn, Richard].

*Ang. I.50 Mayer, Alfred Marshall, editor. Sport with gun and rod in American woods and waters. New York. [cop. I 883.]

1. $8^{\circ}$. pp. 888 . Illustr.

Most of the articles were originally published in the Century.

The illustrations are by J. H. Mills, J. C. Beard, C. C. Ward, etc. Eleven of them are Japan proofs, mounted.

Articles on fish:- The primitive fish-hook; by Barnet Phillips. - Troutfishing in the Rangeley lakes; by Edward Seymour. - Black bass fishing; by J. A. Henshall. - In the haunts of bream and bass; [a poem] by Maurice Thompson. - Salmon-fishing; by A. G. Wilkinson. - Striped bass; by Francis Endicott. - Porpoise-shooting; by C. C. Ward. - The Michigan grayling; by Thaddeus Norris. - Sea-trout fishing; by A. R. Macdonough. - The halcyon in Canada; by John Burroughs. - Among the Thousand Islands; by Howard Pyle. - The split bamboo rod; by William Mitchell and L. D. Alexander.- On the invention of the reel; by A. M. Mayer. - Relation between the weight and length of brook-trout; by W. H. Ellis.-A fight with a trout; by C. D. Warner.

"How to mount a bird; by F. A. Lucas," pp. 833-853.

"Bow-shooting; by Maurice Thompson," pp. 854-879. 
*Ang. 18.15.7 Mayer, John. The sportsman's directory, and park \& gamekeeper's companion; being a series of instructions, in ten parts, for the chase, coursing, shooting, fishing, etc. To which is added an appendix. 7 th ed., comprising the most recent changes in the theory and practice of sporting. London. I 845 . I $6^{\circ}$. Wdcts.

Angling, pp. 63-64, $118-128,172-173$.

Mayer's original work has been enlarged and almost wholly re-written by the editor of the present volume.

Ang. 39.53 . Medwin, Thomas. The angler in Wales; or, Days and nights of sportsmen. 2 vol. London. 1834. $8^{\circ}$. Fronts. and wdcts.

Chatto in his "Angler's souvenir" says of this work: "He might as well have . . called his book the Angler in Hindostan. Independent of the misnomer, it is not written in the spirit of an angler."

Vol. ii. consists principally of travellers' tales, etc., and contains very little on angling.

*Ang. I.I Meidinger, Karl, freiherr von. Icones piscium Austriae indigenorum, quos collegit vivisque coloribus expressos edidit. 5 pt. in I vol. Viennae Austriae. 178594. fo. Col. vigns. and $50 \mathrm{col}$. plates.

\subsection{Another copy of i., ii.}

Ang. 47.35 Meunier, Victor. Les grandes pêches. $2^{\mathrm{e}}$ éd. Illustrée par E. Riou et A. Mesnel. Paris. 1871. sm. $8^{\circ}$. Wdcts. (BIBliothèQue des merveilles.)

Ang. 18.81.5 Meyer, J., assistant in the fischzucht-anstalt at Hiiningen. Handbuch des fischerei-sport; praktischer leitfaden zur fischkunde, zum betriebe der angcl-und netzfischerei, wie der fischzucht. Nebst anhang ïber fischieinde, naturgeschichte, fang und zucht der krebse. Auf grund der neuesten erfahrungen bearbeitet. Wien, etc. I $88 \mathrm{I} . \mathrm{sm} .8^{\circ}$. Illustr. title-page and wdcts.

Ang. 50.68 Michigan-Commissioners and superintendent on fisheries. Ist-4th report for $1873 / 74-1879 / 80$. Lansing. I $875-8 \mathrm{I} . \quad 8^{\circ}$.

*Ang. 38.22 Milford, John. Norway and her Laplanders in I84I. With a few hints to the salmon fisher. London. I $842.8^{\circ}$. I0 $\frac{1}{2} .96$ Another copy.

Ang. 18.78 [Millard, E. E.] Random casts; or, Odds and ends from an angler's note book. By E. M. E. New York. I 878 . I $6^{\circ}$.

*Ang. 44.59 Mills, John, novelist. The life of a foxhound. $2 \mathrm{~d}$ ed. London. I 861. $8^{\circ}$. Front. and plates.

*Ang. I8.45.7 Mills, John, novelist. The sportsman's library. Edinburgh. I $845.8^{\circ}$. Port. and plates.

Contents:- The hunter. - On hunting and hounds. - Shooting. - Game, sporting dogs, \&c. - Fishing. 
Ang. 49.46.I I Miln, W. S. Scotch east coast, Orkney and Shetland, Lewis and Barra herring fishing. Prize essay. London. I $884.8^{\circ}$. pp. 44. Plates, map, and wilct. (LoNDON, Eng. - International fisheries exhibition, i 883. [The fisheries exhibition literature, xi. I I.])

Also another edition.

Ang. 49.46.6 Milne-Home, David. Salmon and salmon fisheries. London. I883. $8^{\circ}$. pp. 58. (LONDON, Eng.-International fisheries exhibition, I883. [The fisheries exhibition literature, vi. 5.])

Also another edition.

[Milnor, William, $j r$.] An authentic historical memoir of the Schuylkill fishing company. 1830. $8^{\circ}$. See Schuylkill fishing company, Philadelphia, Penn.

Ang. 50.95 Minnesota - Fish commissioners. Ist-7th annual report of the commissioners, [for I874]-I880 (in I vol.). Saint Paul, etc. $1875-8$. . $\quad 8^{\circ}$. Wdct.

*Ang. 44.60 [Mitchell, Donald Grant.] Wet days at Edgewood with old farmers, old gardeners, and old pastorals. By the author of "My farm of Edgewood." New York. I 884 [i883]. sm. $8^{\circ}$. Plans.

"A considerable portion of this book was published more than a score of years ago in the Atlantic monthly . . . under the name of "Wet weather work." "- Prefatory note.

"A brace of pastorals [Walton's 'Complete angler,' and Shakespeare's 'As you like it ']," pp. 182-184; "Sir Humphry Davy," pp. 29I-295.

Among the old farmers discussed are Crescenzi, Heresbach, the authors of the "Maison rustique," Sir Hugh Platt, and Gervase Markham.

AL 2469.2I Another copy.

Ang. 49.I5 Mitchell, John Mitchell. The herring; its natural history and national importance. Edinburgh, etc. 1864. $8^{\circ}$. Col. front. and plates.

Ang. 18.24.2 Mitchell, William Andrew. On the pleasure and utility of angling; a paper read to the Waltonian club of Newcastle on Tyne, July 27th, 1824. Newcastle on Tyne. [1824.] sm. $8^{\circ}$. pp. 32. Vign.

This is one of the publications of the Newcastle typographical society.

The vignette on the title-page was engraved by Thomas Bewick. It contains the inscription "Newcastle Waltonian club. Instituted April 5, 1822."

Ang. 49.46 Mitchell, William Stephen. On the place of fish in a hard-working diet; with notes on the use of fish in former times. London. 1884. $8^{\circ}$. (LoNDON, Eng.-International fisheries exhibition, 1883 . [The fisherics exhibition literature, i. 5.])

The date on the cover is $188_{3}$.

Also another edition. 
Ang. 18.65.3 Moerbe, Johannes. Die vollständige angelfischerei in ihrer praktischen und allseitigen anwendung für jeden angler; oder, Leicht fassliche anleitung wie man die fischerei mit der angel und anderen geräthschaften mit gutem erfolge betreiben soll. Nebst belehrungen über künstliche fischzucht und die verschiedenartigen fische, nebst einem fisch- und krebskalender. Nebst allen fisch- und krebsfang-geheimnissen und angabe der besten lockspeisen. $7^{\mathbf{e}}$ stark vermehrte und verbesserte aufl. Berlin. [1887.] sm. $8^{\circ}$.

Ist edition, 1865 .

Ang. 18.65.4 Moffat, A. S. The secrets of angling. Edinburgh. I 865. I $2^{\circ}$. Wdcts.

Ang. 49.46.5 Moloney, Sir Cornelius Alfred. West African fisheries, with particular reference to the Gold Coast colony. London. I883. 8\%. pp. 74. (LoNDON, Eng.-International fisheries exlibition, 1883. [The fisheries exhibition literature, v. I 2.])

"List of memoirs dealing specially with the crustacean-fauna of the west coast of Africa," pp. 73-74.

Also another edition.

Ang. 44.62 Moore, George Henry. Washington as an angler; with extracts from his diaries, I787-89. New York. 1887. sm. $8^{\circ}$. pp. I 5 .

"Printed for the author."

Morgan, George, editor. The new Complete sportsman. [18-?] I $2^{\circ}$. See [Fairfax, Thomas].

Ang. 49.46.8 Morris, C. W. The effect of the existing national and international laws for the regulation and protection of deep sea fisheries, with suggestions for improvements in said laws. Prize essay. London. I 884. $8^{\circ}$. Plate. (LoNDON, Eng. - International fisheries exhibition, i 883. [The fisheries exhibition literature, viii. 2.])

Also another edition.

Ang. 49.17 Moule, Thomas. Heraldry of fish; notices of the principal families bearing fish in their arms. London. 1842. $8^{\circ}$. Wdcts. and coats-of-arms.

Mr. Briggs \& his doings. [1 860.] obl. $4^{\circ}$. See [Leech, John].

*Ang. I.4 Müller, Johannes (180I-I858), and Henle, Jakob. Systematische beschreibung der plagiostomen. Berlin. I $84 \mathrm{I}$. fo. 60 plates.

"Literatur," pp. xi.-xiv., 200-[204].

Most of the plates are colored. 
Ang. 48.3I Mulertt, Hugo. The goldfish and its systematic culture with a view to profit. A practical treatise on the fish, its propagation, enemies, diseases, and care of the fish in captivity, with hints on the construction of ponds, etc. Cincinnati. I 883. $8^{\circ}$. Col. front., plan, and wdcts.

Mulertt, Hugo. How to cook fish. I887. I $6^{\circ}$. See Verein deutscher fisch haendler.

*Ang. 24.3 [Mullen, W.] Rambles after sport; or, Travels and adventures in the Americas and at home. By "Oliver North" [pseudon.]. London. I874. sm. $8^{\circ}$.

Articles reprinted from the Field; including "Two days' fishing in Chile," pp. 209-222.

Ang. 49.46.7 Mundahl, C. M. Line fishing. London. I883. $8^{\circ}$. pp. 23. (London, Eng. - International fisheries exhibition, I883. [The fisheries exhibition literature, vii. I I.])

Also another edition.

Ang. 49.46.II Munro, R. J. The herring fisheries. Prize essay. London. I884. $8^{\circ}$. pp. (2), $4^{2}$. (LONDON, Eng. International fisheries exhibition, I883. [The fisheries exhibition literature, xi. 9.])

Also another edition.

*Ang. 29.5 Murray, William Henry Harrison. Adventures in the wilderness; or, Camp-life in the Adirondacks. Boston. I 869. sm. $8^{\circ}$ or $12^{\circ}$. Front., plates, and wdcts.

Chapters 2 and 7 are on fishing.

"Several of the chapters were originally published in the Meriden literary recorder, I867."

Criticized in R. G. Allerton's "Brook trout fishing," pp. 30-43.

II375.4I Another copy.

*Ang. 46.24 Napier, Charles Ottley Groom. Natural history rambles. Lakes and rivers. London, etc. I880. I $6^{\circ}$. Wdcts.

" Fresh-water fishes," pp. 129-157; "Some of the typical rivers and their fisheries," pp. 158-190.

Ang. 46.2 Neckam, Alexander. De naturis rerum libri duo. With the poem of the same author, De laudibus divinæ sapientiæ. Edited by Thomas Wright. Published under the direction of the master of the rolls. London. I $863.1 .8^{\circ}$. pp. 4 , Ixxviii., (2), 52 I. (CHRONICLES and memorials of Great Britain and Ireland during the middle ages, 34.)

Chapters 22-46 of the second book treat of fishes and the hippopotamus. Chapter 47 describes the construction of a fishing net.

Neckam was abbot of Cirencester in 1213 .

Brit. Hist. 726 - Another copy. 
Ang. 18.17.2 Needham, T. H. The complete sportsman. Containing a compendious view of the ancient and modern chase, the ancient forest and game laws, angling, and the laws relating to fish; with every instruction and information relative to the diversions of the field. I.ondon. I8I 7 . I $2^{\circ}$.

"Angling" and "Laws relating to fish," pp. 300-3II.

With the armorial book-plate of Charles Henry Turner.

Ang. 18.04.2 Neil, A. of London. New and complete angler; or, The whole art of catching fish. Containing every necessary instruction for that amusement. To which is added a correct abstract of the several acts of parliament with respect to angling. London. [cir. I 804.] sm. I $2^{\circ}$. pp. 38. Front.

The frontispiece has the date 1804 .

All the earlier editions of the work are undated.

Nessmuk, pseudon. See Sears, George W.

Ang. 49.25 Nettle, Richard. The salmon fisheries of the St. Lawrence and its tributaries. Montreal. I857. I $2^{\circ}$.

" Artificial fly fishing," pp. 130-134; "Trout fishing," pp. 135-144.

\subsection{Another copy.}

*Ang. 18.43 New sporting almanack (The); a manual of instruction and amusement. Edited by Wildrake [George Tattersall]. 1 843, I 844. 2 vol. London. [1842-43.] I $6^{\circ}$. Fronts., engr. title-pages, plates, and wdcts.

Each volume contains a few pages relating to angling.

Newcastle fishers' garlands. See Fisher's garland (The). I $82 \mathrm{I}$, etc. $8^{\circ}$, also Collection of right merrie garlands for north country anglers. I 864. So.

Ang. 50.60 New Hampshire-Commissioners on fisheries. Report of the commissioners, I87I-I874, I876-I88I/82. II pam. Nashua, etc. 1871-82. $8^{\circ}$. Fronts., plates, wdcts., and plans.

The reports for $1877^{-188}$ I have the title, "Report of the fish commissioners;" the one for $188 \mathrm{I} / 82$ has the title, "Report of the fish and game commissioners."

To the reports for $1877-1881 / 82$ are appended the addresses delivered before the annual meetings of the fish and game league of New Hampshire.

Ang. 50.49 New Jersey-Commissioners of fisheries. Ist-7th, [9th] annual report of the commissioners [for 1870], I 876 . I 878 (in I vol.). Trenton, N. J. I87 I-78. $8^{\circ}$. Maps and plan.

Ang. 39.58 Newland, Henry. The Erne; its legends and its flyfishing. London. I $85 \mathrm{I}$. sm. $8^{\circ}$. Col. front., engr. titlepage, map, and 4 plates.

The frontispiece contains six illustrations of flies, and on the engraved titlepage is a colored illustration of the "fairy fly." The plates are from sketches made by the author's brother. 
Ang. 38.14 Newland, Henry. Forest scenes in Norway and Sweden; being extracts from the journal of a fisherman. $2 \mathrm{~d}$ ed. London, etc. I $855 . \mathrm{sm} .8^{\circ}$. Front. and plates.

Ist edition, I 854 .

Westwood and Satchell consider this a type " of the higher class of angling literature."

Also with the title, "Forest life: a fisherman's sketches in Norway and Sweden."

Ang. 50.63 New York (State) - Commissioners of fisheries. [Ist]I 6 th, I 8th report of the commissioners, transmitted to the legislature I 869-1 888, I 890. [With appendices.] Albany, etc. I 869-90. $8^{\circ}$. Fronts., maps, plates, etc.

After 1884 , the reports contain the reports of the game and fish protectors.

Ang. 50.63.2 Fisheries of the state of New York. Report of the commissioners, transmitted to the legislature March 9, I 869. Albany. 1869. $8^{\circ}$. pp. 75. Map.

This is another edition of the Ist report.

Ang. I2.3I New York (City)-Grolier club. Chronological handlist of various editions of the Complete angler by Izaak Walton and Charles Cotton; with a supplement embracing other writings of Walton and Cotton, etc. 1593-1893. Exhibited at the Grolier club Dec. 9-29, 1893. [New York.] 1893. sm. $8^{\circ}$. pp. 26.

Describes 59 editions of the "Complete angler." The exhibition was designed to commemorate the 300 th anniversary of the birth of Walton.

Editions in Harvard college library are noted in this copy.

Ang. 22.16 New York (City)-Ichthyophagous club. [Announcements and menus of the 5 th and 6 th annual dinners of the club, Oct. I 7, I 884 and Oct. 21,1885 . New York. 188485.] \quad 8^{\circ}$ and sq. $16^{\circ}$.

The menus are illustrated with caricatures of members of the club, and the names have been supplied in pencil. The menu of the $5^{\text {th }}$ dinner contains a poem by Fred Mather, entitled " When the Ichthyophagous dines."

Nichol, Robert. The fisher's garland for 1833. See Fisher's garland (The). I 821 , etc. $8^{\circ}$. Note.

Ang. 60.8 Ninni, Alessandro Pericle, Conte. Araldica pescatoria. Venezia. I 890 . sm. $8^{\circ}$. pp. 8.

Sull" " usanza dei veneti pescatori di adoperare speciali insegne per contraddistinguere le loro barche."

*Ang. 16.82 [Nobbes, Robert.] The compleat troller; or, The art of trolling. With a description of all the utensils, instruments, tackling, and materials requisite thereto, with rules and directions how to use them; as also a brief account of most of the principal rivers in England. By a lover of the sport. London. I682. I $6^{\circ}$. pp. (20), $78+$. Wdcts.

This work is also found in the "Angler's pocket-book," and is appended to the editions of 1814 and 1822 of Thomas Best's "Art of angling," and to the "Angler's companion." 
Ang. 18.64.4 Norris, Thaddeus. The American angler's book; embracing the natural history of sporting fish, and the art of taking them. With instructions in fly-fishing, fly-making, and rod-making, and directions for fish-breeding. To which is added Dies piscatoriæ, describing noted fishingplaces, and the pleasure of solitary fly-fishing. New ed., with a supplement containing descriptions of salmon rivers, inland trout fishing, etc. Philadelphia, etc. $1865.8^{\circ}$. pp.,70I. Front., plates, and rudcts.

Ist edition, I 864 .

"Mr. Norris has undertaken to supply the omissions of those writers who have preceded him in describing American fishes, and to correct certain erroneous notions about angling, which have arisen from adopting too rigidly the English rules and practices."-Nation, vol. i. p. 818.

Ang. 18.64.4.2 The same. New ed., with a supplement. Philadelphia. [cop. 1865.] $8^{\circ}$. pp. 701. Front., plates, and wdcts.

The frontispiece is from a new plate.

Ang. 48.9 Norris, Thaddeus. American fish-culture; embracing all the details of artificial breeding and rearing of trout, the culture of salmon, shad, and other fishes. [With an appendix.] Philadelphia, etc. $1868 . \quad$ sm. $8^{\circ}$ or $12^{\circ}$. Front., wdcts., and plates.

46.59 Another copy.

Ang. 18.17 North Country angler (The); or, The art of angling as practised in the northern counties of England. [4th ed., with additions.] London, etc. I8I7. I $2^{\circ}$. pp. iv., 89. Vign.

Ist edition, I 786 .

North, Oliver, pseudon. See Mullen, W.

Ang. 48.17 [North, Roger.] A discourse of fish and fish-ponds. Done by a person of honour. London. I7/3. sm. $8^{\circ}$. pp. (8), 79 .

Treats especially of the culture of carp.

Osmund Lambert, in his "Angling literature in England," calls this " the principal English work of early date on fish-culture."

*Ang. 48.18 [-] The same. 2d ed. London. I715. sm. I $2^{\circ}$.

*Ang. 1.27 The same. (Appended to Albin, Eleazar. The history of esculent fish, I 794, $4^{\circ}$, pp. 33-78.)

This was also appended to the "Gentleman farmer," 1726.

*Ang. 27.3 Northrup, Ansel Judd. Camps and tramps in the Adirondacks, and grayling fishing in northern Michigan. A record of summer vacations in the wilderness. New York. [1880?] I $8^{\circ}$.

The chapters on the Adirondacks contain many fshing incidents. 
Novice, A., A. F. E F., pseudon. The anglican friar. See Anglican friar (The). I 85 I. I $2^{\circ}$.

*Ang. 38.8 0'Connor, Roderic. An introduction to the field sports of France; being a practical view of hunting, shooting, and fishing on the Continent. With a concise notice of the habits and instincts of the several animals in question, and a sketch of the game and piscatory laws of France. London, etc. $\quad$ I $846 . \quad$ I $2^{\circ}$. Wdcts.

"Fishing," pp. 223-298.

Ang. 18.45.8 0 'Gorman, - - The practice of angling, particularly as regards Ireland. 2 vol. in I. Dublin. I $845.8^{\circ}$. Port.

Ang. 50.68 Ohio-Fish commission. Ist-8th, Ioth-I2th annual report for $1875 / 76-1883,1885-1887$. Columbus. I $877-$ 88. $8^{\circ}$. Plates and wdcts.

Ang. 49.46.5 Okoshi, Narinori. A sketch of the fisheries of Japan. London. I 883. 8. . $^{\circ}$. 39. (LoNDON, Eng.-International fisheries exhibition, 1883. [The fisheries exhibition literature, v. 5.])

Also another edition.

01d house (The) by the river. 1874. I $2^{\circ}$. See [Prime, W. C.].

*Ang. 44.65 01d Calabar, pseudon. Over turf and stubble. London. I873. sm. $8^{\circ}$.

"A pike story," pp. 23-43; "Conger eel fishing at Jersey," pp. 44-60; "A night amongst the sand eels," pp. 61-73; "Fishing gossip," pp. 74-116.

Oliver, Stephen, the younger, pseudon. See Chatto, William Andrew.

Ang. 49.43 Omond, James. Model of the safest and handiest sailing fishing-boat, as to hull, sails, spars, and rig. 3 plates. (In Herbert, David, editor. Fish and fisheries, I $883,8^{\circ}$, pp. 332-342.)

Go 8.I2 Oppianus. De venatione lib. iv. De piscatu lib. v. Cum interpretatione latina, commentariis, \& indice confectis studio Conradi Rittershusii, qui \& recensuit hos libros denuo, \& Adr. Turnebi editionem parisiensem cum trib. MSs. palatinis contulit; inde \& var. lect. \& scholia græca excerpsit. Lugduni Batavorum, apud Franciscum Raphelengium. 1597. I $6^{\circ}$. pp. (88), 376, (40), 344, I64, (3).

"Catalogus eorum qui de piscibus præter Oppianum aliquid scripserunt," pp. (7I)-(73) of the prolegomena. 
Go 8.17 Oppianus. Cynegetica et Halieutica; ad fidem librorum scriptorum emendavit J. G. Schneider. Accedunt versiones latinae metrica et prosaica, plurima anecdota, et index graecitatis. [Edited by G. H. Schaefer.] Lipsiae. I813. $8^{\circ}$.

Contains only the Greek text, with a few notes, and a Latin translation of the "Cynegetica" in verse, by David Peifer. Schaefer announces the appearance of a second volume, to contain the remainder of the work. This volume was never published.

G 195 Oppianus. De venatione. - De piscatione. [Edited by G 196 F.S. Lehrs.] Gr. and Lat. (In PoET E bucolici et didactici, I $851,8^{\circ}$, [ii.] I-IO6.) 2 cop.

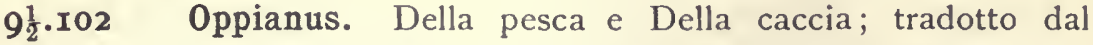
greco ed illustrato con varie annotazioni da Antonmaria Salvini. Nuova ed., coll' aggiunta delle notizie sulla vita dell' autore per G. A. Greenhill. [Edited by Giulio Antimaco.] Milano. 1864. I $6^{\circ}$. (Biblioteca rara, 48.)

" Notizie, intorno ad Oppiano," pp. xi.-xxii.

*Ang. 45.59 Oppianus. Halieuticks of the nature of fishes and fishing of the ancients, in v. books. Translated from the Greek, with an account of Oppian's life and writings, and a catalogue of his fishes, [by William Diaper and John Jones]. Oxford. I 722 . $8^{\circ}$.

The first two books treat of the nature of fishes and the others of the fishing of the ancients.

"Oppian holds the foremosit rank among the ancient writers on Halieutics." - T. Westrwood.

"Contains much fable and absurdity with considerable zoölogical knowledge." - Westruood and Satchell.

Go 8.30 Another copy.

*Ang. 18.83.2 Orvis, Charles F., and Cheney, A. Nelson, editors. Fishing with the fly; sketches by lovers of the art. Manchester, Vermont. 1883. sm. $4^{\circ}$. 15 col.plates.

The title-page is illustrated. The plates, which contain illustrations of flies, are colored lithographs by Orvis.

Otter, pseudon. See Alfred, H. J.

Ovidius. La vieille, ou Les dernières amours d'Ovide. I 861. $8^{\circ}$. See Fournival, Richard DE.

Palmer, Black, pseudon. See Black Palmer, pseudon.

Ang. 47.47 Pappe, Ludwig. Synopsis of the edible fishes at the Cape of Good Hope. Cape Town. 1853. $\quad 8^{\circ}$. pp. 34.

Ang. 47.I7 Parnell, Richard. Prize essay on the fishes of the district of the Firth of Forth. Edinburgh. $1838 . \quad 8^{\circ} .28$ plates.

Reprinted from the Memoirs of the Wernerian natural history society, 1838 , vii. $161-460,515-520$.

"The society's honorary premium of a gold medal, value ten sovereigns, was adjudged to Dr. Parnell for this essay, 1837." 
Ang. 49.22 Paterson, James, M.A. A treatise on the fishery laws of the United Kingdom, including the laws of angling. London, etc. I $863 . \quad \mathrm{sm} .8^{\circ}$. Imperfect: - last pages of table of contents, wanting. With special reference to the salmon fisheries.

*Ang. 47.16 Patterson, Robert Lloyd. The birds, fishes, and cetacea commonly frequenting Belfast lough. London, etc. i $880.8^{\circ}$. Map.

"Fish and fishing," pp. 203-257.

"The greater portion of the matter in this volume was originally brought together in the form of papers, read before the Belfast natural history and philosophical society." - Preface.

*Ang. 24.2 Payton, Charles A. Moss from a rolling stone; or, Moorish wanderings and rambling reminiscences. London. I 879. sm. $8^{\circ}$. Front.

Contains many chapters on fishing.

Many of the chapters originally appeared in the Field and the Country, under the pseudonym of "Sarcelle."

*Ang. 48.15 Peard, William. Practical water-farming. Edinburgh. I 868 . I $6^{\circ}$.

Ang. 39.57 Peard, William. A year of liberty; or, Salmon angling in Ireland, from Feb. I to Nov. I, [I865]. London. I $867 . \mathrm{sm} .8^{\circ}$.

Pearson, Edwin, editor. The angler's garland and fisher's delight. See Angler's garland (The), and fisher's delight. I 870, etc. $4^{\circ}$.

Ang. 39.65 Peel, E. Lennox. A Highland gathering. With illustrations engraved by $\mathrm{E}$. Whymper from original drawings by Charles Whymper. London. I $885 . \mathrm{sm} .8^{\circ}$. Front. and wdcts.

Half-title :- "Sporting tales."

Papers reprinted from various periodicals.

"An angler's dream," pp. I3-23; "That big trout," pp. 57-66; "Springtime by the river," pp. III-II8; "On loch Lydoch," pp. I6I-I68.

Ang. 47.20 [Peel, Jonathan.] A treatise on fly-fishing; by "Dinks." Containing complete and elaborate directions for every thing connected with the art and science of fly-fishing, the materials, mode of tying, colors, seasons, and uses of all the most killing varieties of artificial flies, etc. Wdcts. (Appended to Herbert, H. W. Frank Forester's fish and fishing, I $864,8^{\circ}$, pp. 439-498, 5 I I-5 I2.)

Ang. 18.33.3 Penn, Richard (d. 1863). Maxims and hints for an angler, and Miseries of fishing. To which are added, Maxims and hints for a chess player. New ed., enlarged. London. $1839 \quad 16^{\circ}$. pp. (4), 79. Front., plates, and wdcts.

"'The 'Maxims' are extracts from the common place book of the Houghton fishing club, on the Test. The author was the great grandson of William Penn, the founder of Pennsylvania." - Westroood and Satchell. 
Ang. 18.33.4 [Penn, Richard (d. I 863).] Maxims and hints for an angler, with Miseries of fishing. To which are added, Maxims and hints for a chess player. Philadelphia. I 868. sm. I $2^{\circ}$. pp. 6o. Front. and plates.

This edition does not contain all the material found in the 1839 edition.

*Ang. 47.26 Pennell, Henry Cholmondeley. The angler-naturalist; a popular history of British fresh-water fish, with a plain explanation of the rudiments of ichthyology. London, etc. [1875?] I $2^{\circ}$. Wdcts.

Most of the illustrations are borrowed from Yarrell's " History of British fishes."

Ist edition, 1863 .

*Ang. 18.65.6 Pennell, Henry Cholmondeley. The book of the pike; a practical treatise on the various methods of jack fishing, with an analysis of the tackle employed, the history of the fish, \&c. Also a chapter on spinning for trout in lakes and rivers. London. $1865 . \mathrm{sm} .8^{\circ}$. Col. front., plates, and wdcts.

The second part of the work, which treats of pike fishing, was originally published in the Fisherman's magazine and review, 1864-65, and most of the illustrations are taken from that journal.

*Ang. I8.76.2 Pennell, Henry Cholmondeley. Bottom or float-fishing. London, etc. $[1876.] \mathrm{sm} .8^{\circ}$. Front. and wdcts.

Pennell, Henry Cholmondeley, editor. The fisherman's magazine and review. See Fisherman's magazine and review (The). I 864, etc. $8^{\circ}$.

*Ang. 18.85.7 Pennell, Henry Cholmondeley. Fishing. With contributions from other authors [William Senior, G. C. Davies, H. R. Francis, and others]. 2 vol. London. 1885. $8^{\circ}$. Large paper. Fronts. and wdcts. (The BADMINTON library of sports and pastimes.)

"Only 250 copies printed. No. 58 ; No. 34 ."

Contents:- i. Salmon and trout. - ii. Pike and other coarse fish.

VII. 2050 The same. 2 vol. London. 1887, '86. $8^{\circ}$.

Fronts. and wdcts. (Ditto.)

Vol. i. is " 3 d ed.;" ii. is " 2 d ed."

*Ang. 18.66.3 Pennell, Henry Cholmondeley, editor. Fishing gossip; or, Stray leaves from the note-books of several anglers. Edinburgh. $1866.5 m .8^{\circ}$. Front., plate, and wdcts.

Many of these articles were originally published in the Fisherman's magazine, and the frontispiece is taken from that journal.

*Ang. 18.76.3 Pennell, Henry Cholmondeley. Fly-fishing and wormfishing for salmon, trout, and grayling. London, etc. [i 876.] sm. $8^{\circ}$. Front. and wdcts.

"In regard to the theory and practice of artificial fly-making and fishing, the author has arrived at conclusions very different to those usually accepted by anglers and angling writers. . . . On this point a reviewer in Baily's monthly magazine observes:- 'The result of Mr. Pennell's teaching is the substitution of six typical flies for the whole of the artificial flies now used." "-Note. 
*Ang. 18.70.5 Pennell, Henry Cholmondeley. The modern practical angler; a complete guide to fly-fishing, bottom-fishing, \& trolling. London, etc. [1870?] sm. $8^{\circ}$. Col. front., platcs, and wodcts.

"The engravings of fish have been taken from carefully selected specimens obtained in every instance from the localities most celebrated for each particular species, and have been executed under my own eye."-Preface.

Reviewed by W. C. Stewart in his "Caution to anglers," 1871 .

*Ang. 18.62.4 Pennell, Henry Cholmondeley. Spinning-tackle; what it is and what it ought to be, with a few words on finefishing. London. 1862. 24\% pp. 32. Wdcts.

Half-tille:- " How to spin for pike."

The substance of a portion of this work appeared in the form of letters to the Field, and the woodcuts are borrowed from that journal.

*Ang. 47.10 Pennell, Henry Cholmondeley. The sporting fish of Great Britain, with notes on ichthyology. London. I 886.

1. $8^{\circ}$. Col. front., wdcts., and I 7 plates.

All but two of the plates are colored.

*Ang. 18.76.4 Pennell, Henry Cholmondeley. Trolling for pike, salmon, and trout. London, etc. $\left[1876 . j \mathrm{sm} .8^{\circ}\right.$. Front. and wdcts.

Ang. 50.73 Pennsylvania-Commissioners of fisheries. Report of the commissioners for I873, I874, I 876, I877, I88 I $/ 82$. I vol. and 4 pam. Harrisburg. I874-83. $8^{\circ}$. Plates, plan, map, and diagr.

*Ang. 49.42 Perley, Moses Henry. Reports on the sea and river fisheries of New Brunswick. [With a descriptive catalogue of the fishes of New Brunswick and Nova Scotia.] 2d ed. Fredericton. I $852 . \quad 8^{\circ}$.

"Separately laid before the legislature in 1849,1850 , and 1851 , and severally printed. Copies having become scarce, they are now reprinted collectively."

4344.6 Another copy.

Ang. I.24(i, ii) Perry, Matthew Calbraith. Narrative of the expe36.68 dition of an American squadron to the China seas and Japan, in 1852,1853 , and 1854 , under the command of M. C. Perry. 2 vol. Washington. $1856.4^{\circ}$. Plates, wdcts., maps, etc. (United States Japan expedition, i., ii.) 2 cop.

33d cong. 2d sess. Senate. Ex. doc. no. 79.

Vol. i. is "compiled from the notes and journals of Commodore Perry and his officers, by F. L. Hawks."

- Many of the plates are colored.

"Notes on some figures of Japanese fish, by J. C. Brevoort," ii. 253-288.

13.14 Another copy.

Imperfect: - plate wanting in vol. ii.

13.25 The same. 2 vol. Washington. I $856.4^{\circ}$. Plates, wdcts., maps, etc. (Ditto.)

$33^{d}$ cong. 2 d sess. House. Ex. doc. no. 97 . 
Ang. 50.2.4(I4) Philadelphia, Penn.-International exhibition, I 876. Catalogue of the collection to illustrate the animal resources and the fisheries of the United States. Exhibited by the Smithsonian instituticn and the United States fish commission, and forming a part of the United States national museum. Prepared under the direction of G. B. Goode. Washington. I879. $8^{\circ}$. (U. S. NATIONAL MUSEUM. Bulletin, I4.)

"Catalogue of illustrations of the economical invertebrates of the American coasts; by W. H. Dall," pp. 249-271.

VIII. 39(I4) Another copy.

I22.24 The same. Washington. i879. (In SMithSONIAN miscel. coll., I $882,8^{\circ}$, xxiii. 4.)

Ang. 29.7 Philadelphia, Wilmington and Baltimore railroad. A paradise for gunners and anglers. [Philadelphia.] I 883 . sm. $8^{\circ}$. pp. 96 . Map and wdcts.

The object of this work is to direct the attention of sportsmen to the Dela. ware and Maryland peninsula.

*Ang. 22.13(iii) Phillips, Barnet. The primitive fish-hook. Wdcts. (In Halieutics by modern writers, [iii. art. 15].)

Century, 1883, xxv. 898-904.

*Ang. I.50 - The same. Wdcts. (In MAYER, A. M., editor. Sport with gun and rod, [cop. I 883], $8^{\circ}$, pp. 337-350.)

Ang. 45.64 Phillips, Henry (1801-1876). The true enjoyment of angling. London. I $843.1 .8^{\circ}$. Port.

"Suhscriber's copy. Only 100 printed."

"The work is divided into months, from March to September inclusive. Each month has a prose essay and a song set to music. The author was a celebrated singer." - Westruood and Salchell.

Ang. 18.35 [Pickering, William.] Bibliotheca piscatoria; a catalogue of books upon angling. London. I836. pp. (40). Wdct. (Appended to [Boosey, Thomas]. Piscatorial reminiscences and gleanings, I 835, I $6^{\circ}$.)

This catalogue is formed upon Sir Henry Ellis's corrected copy of the list which he contributed to the "British bibliographer" in $\mathrm{I} 8 \mathrm{II}$, and contains I80 works, two or three of which, however, have no direct relation to angling.

Ang. 48.13 Piscarius, pseudon. The artificial production of fish. 3 d ed. London. I852. sm. $8^{\circ}$. pp. 22.

Piscator, pseudon. See Hughes, William.

Piscator, pseudon. See Lathy, Thomas Pike.

Piscatorie eclogs. 1633. $4^{\circ}$. See [Fletcher, Phineas].

Piscatory eclogues. I 729. $8^{\circ}$. See [Browne, Moses].

Pisciceptologie; ou, L'art de la pêche à la ligne. 1823. I $2^{\circ}$. See [Cussac, J.]. 
*Ang. 1.14 Playfair, Sir Robert Lambert, and Ginther, Albrecht Karl Ludwig Gotthilf. The fishes of Zanzibar. Acanthopterygii, by R. L. Playfair; pharyngognathi, etc., by A. C. L. G. Guinther. London. 1866. $4^{\circ}$. Wdcts. and 2 I plates.

The plates are lithographs by G. H. Ford; 6 of them are colored, and plate 13 is used as a frontispiece.

Pleasures (The) of princes. $1635 .{ }^{\circ} 4^{\circ}$. See [Markham, Gervase].

Ang. 18.02 Pollard, Richard, of Clapton. The new and complete angler; or, Universal fisherman. Containing the most approved instructions and modern methods of breeding fish, etc., with explanation of technical phrases, \&c. London. [1802.] I $2^{\circ}$. pp. 70.

Imperfect: - frontispiece wanting.

"All but a literal transcript of "The true art of angling' by J. S." - Westrwood and Satchell.

Ang. 49.46 Pollock, Sir Frederick, $3 d$ bart. The fishery laws. London. I883. $8^{\circ}$. pp. 48 . (LondoN, Eng. - International fisheries exhibition, I883. [The fisheries exhibition literature, i. 3.])

Also another edition.

*Ang. 40.2 Pollok, Fitz William Thomas. Sport in British Burmah, Assam, and the Cassyah and Jyntiah hills. With notes of sport in the hilly districts of the northern division, Madras Presidency, indicating the best localities for sport, with natural history notes, and hints on weapons, fishingtackle, etc., best suited for killing game in those provinces. 2 vol. London. 1879 . $8^{\circ}$. Col. fronts., maps, and 8 plates.

"Many of the original journals from which this book is compiled have appeared in the Oriental sporting magazine."

Chapter 6 of vol. i. and chapters 3 and 7 of vol. ii. contain accounts of fishing.

All but two of the plates are colored.

I7374.52 Porter, William Trotter. Angling. (In Brinley, Francis. Life of W. T. Porter, I $860, \mathrm{I}^{\circ}$, pp. 2 I I-244.)

Ang. 49.46.4 Practical fishermen's congress, London, Eng. I883. Destruction of immature fish; harbour accommodation; better means for prevention of loss of life at sea; railway rates; fishing vessels' lights. [Subjects discussed.] London. 1884. 8. (LONDON, Eng.-International fisheries exhibition, 1883 . [The fisheries exhibition literature, iv. 8.])

The discussion of the last subject was postponed.

Also another edition. 
Practical observations on angling in the river Trent. I801. 1 $2^{\circ}$. See [Snart, Charles].

AL 2993.3.10 Prime, William Cowper. Along New England roads. New York. I 892 . sm. $8^{\circ}$.

Contents : - Along New England roads. - In southern Vermont. - A village discussion. - Uphill in fog. - Sweet-scented fern. - An angler's August day. - Views from a hill-top. - Over the highlands of western New Hampshire. - The triumphant chariot. - A dead letter. - Epitaphs and names. Finding new country. - Boys with stand-up collars. - Pilgrimage ended. Non-resistance. - Songs of the ages. — Ignotus. - Seeking a better country. - A winter night's errand. - Hints for carriage travel.

These papers originally appeared as letters to the New York Fournal of commerce in the course of a correspondence extended over more than forty years,

AL 2993.3.12 Prime, William Cowper. Among the northern hills. New York. I 895 . sm. $8^{\circ}$.

Contents :- The primeval forest. - A trout-stream. - An up-country artist. - Beyond. - An old angler. — Doughnuts and tobacco. — John Ledyard. Thursday-evening meeting. - An Easter long ago. - An old-time Christmas. - Alone at Thanksgiving. - How the old lady beat John. - Philistis. - A northern sleigh-ride. - Life seen through a window. - Colored people. - Example. - The sign of the cross. - A child's voice. - Puritan Sunday.

Ang. 44.7I Prime, William Cowper. I go a-fishing. London. I $873 . \mathrm{sm} .8^{\circ}$.

Describes fishing excursions in New Hampshire, Connecticut, etc.

AL 2993.3.2I — The same. New York. i $873 . \quad 8^{\circ}$. Wdct.

Imperfect: - title-page and pp. 363-365 badly torn.

The woodcut is a fac-simile of a picture found in the "Dyalogus creaturarum," a work attributed to Nicolaus Pergamenus, Gouda ed., 1482 .

Ang. 44.72 The same. New York. 1874. 8\%. Wdct.

The preceding edition with a new title-page.

*Ang. 44.73 [Prime, William Cowper.] The old house by the river. By the author of the "Owl creek letters." New York. I 874 [cop. I 853]. I $2^{\circ}$.

"Trout-fishing," pp. 15I-178.

*Ang. 18.88.2 Pritt, Thomas Evan. The book of the grayling; being a description of the fish and the art of angling for him, as practised chiefly in the midlands and the north of England. With illustrations in chromo-lithography, from original drawings by the author. Leeds. $1888.8^{\circ}$. pp. 64. Col. front. and 2 col. plates.

*Ang. 18.85.4 Pritt, Thomas Evan. North-country flies. Comprising illustrations from the author's own drawings, with particulars of the dressings and season of each fly, and chapters on fishing the minnow, the creeper, the stonefly, and the worm in clear water. $2 \mathrm{~d}$ ed. London. 1886. $8^{\circ}$. pp. 63.12 plates.

"The first edition was published under the title of 'Yorkshire trout flies,' but it was pointed out in quarters entitled to high respect, that the title was too local. . . . It was therefore decided to alter the title, the text remaining identical." - Preface. 
*Ang. 18.85.3 Pritt, Thomas Evan. Yorkshire trout flies. Comprising illustrations from the author's own drawings, with particulars of the dressings and season of each fly, and chapters on fishing the minnow, the creeper, the stonefly, and the worm in clear water. Leeds. I885. $8^{\circ}$. pp. 63. 12 plates.

The following note is written in pencil above the half-title: "The plates in this copy are drawn \& painted by mc. Only thirty copies have been so done. T. E. Pritt." This refers to the II colored plates of flies, each of which has - a the author's signature in pencil. Plate 12 contains illustrations of hooks.

The second edition has the title "North-country flies."

10335.10 Procter, George Henry. The fishermen's memorial and record book; containing a list of vessels and their crews lost from the port of Gloucester from I 830 to Oct I, 1873 . It also contains valuable statistics of the fishing business, off-hand sketches, big trips, tales of narrow escapes, maritime poetry, and other matters of interest to these toilers of the sea. Gloucester. I873. $8^{\circ}$. Wdcts. and port. of F. F. Watson.

Ang. 49.7 [Procter, George Henry, compiler.] The fishermen's own book; comprising the list of men and vessels lost from the port of Gloucester, Mass., from I874 to April I, I 882, and a table of losses from 1830 , with valuable statistics of the fisheries. Also notable fares, narrow escapes, startling adventures, fishermen's off-hand sketches, ballads, descriptions of fishing trips, and other interesting facts and incidents connected with this branch of maritime industry. Gloucester. [cop. I 882.] $8^{\circ}$. Plates and wdcts.

A companion volume to his "Fishermen's memorial and record book."

10335.10.2 Another copy.

Ang. 18.83 Prouty, Lorenzo. Fish; their habits and haunts and the methods of catching them, with fishing as a recreation. Boston. 1883. $8^{\circ}$. Port.

Ang. 39.2 Pulman, George P. R. The book of the Axe; containing a piscatorial description of that stream, and a history of all the parishes and remarkable spots upon its banks. [3d ed.] London. 1854. sm. $8^{\circ}$. Map, wdcts., I I plates, etc.

"What may be called an outline of this work was published about ten years since [ $1844-45]$, when two editions were rapidly sold off; and the work has for at least eight years been out of print." - Preface.

Ang. 39.1 - The same. 4th ed., re-written and greatly enlarged. London. I 875 ['73-75]. 1. 8'. pp. vi., (2), 906. Map, zudcts., I6 plates, etc.

"Contains nearly four times as much matter as the third edition, and quite four times as many illustrations." 
Ang. 39.Io [Pulman, George P. R.] Rambles, roamings, and recollections. By John Trotandot [pseudon.]. London. 1870. sm. $8^{\circ}$.

"Most of the skelches contained in the following pages have appeared from time to time, during the past ten or twelve years, in a local newspaper."

" Piscatorial reminiscences," pp. 82-89; "By the sea, an evening's 'blinning,' " pp. 133-141.

Ang. 18.41.2 Pulman, Gcorge P. R. Vade mecum of fly-fishing for trout; being a concise practical treatise on that branch of the art of angling. Axminster. I841. 16 $6^{\circ}$ pp. 61 .

*Ang. 18.41.3 The same. With tables of flies, arranged on an entirely new plan. $2 \mathrm{~d}$ ed., re-written and greatly enlarged. London. I 846. I $6^{\circ}$.

Ang. I8.4I.4 The same. With plain and copious instructions for the manufacture of artificial fies. $3 \mathrm{~d}$ ed., re-written and greatly enlarged. London. I $85 \mathrm{I}$. I $6^{\circ}$. Wdcts.

"The present edition may be considered as an entirely new work, so extensive are the additions, and so altered is its style of publication." - Preface. With the armorial hook-plate of Samuel T. Tisdale.

*Ang. 47.7 Putnam, Frederick Ward. The blind fishes of the Mammoth cave, and their allies. Wdcts. and 2 plates. (In the American naturalist, i 872, $8^{\circ}$, vi. 6-30.)

47.I29 Another copy.

Ang. 49.46.5 Ramsay, Edward Pierson. Notes on the food fishes and edible mollusca of New South Wales, etc., exhibited in the New South Wales court. London. I $883.8^{\circ}$. pp. 53. (LONDON, Eng. - International fisheries exhibition, I883. [The fisheries exhibition literature, v. 9.])

Also another edition.

Ang. 39.64 Randall, John. Handbook to the Severn Valley railway; illustrative and descriptive of places along the line, from Worcester to Shrewsbury. London. I 863. sm. $8^{\circ}$. pp. 50. Wdcts.

Mentions places where fishing may be found.

Random casts; or, Odds and ends from an angler's note book. I878. I $6^{\circ}$. See [Millard, E. E.].

Ang. I.12 Rau, Charles. Prehistoric fishing in Europe and North America. Washington. I884. fo. Front., wdcts., and plans.

"Smithsonian contributions to knowledge. 509."

$23 \frac{1}{2} \cdot 31-$ The same. Washington. 1884 . Front., wdcts., and plans. (In SMithsonian contributions to knowledge, I $885, f^{\circ}, \operatorname{xxv} .[\mathrm{i}$.$] .)$ 
Ang. I8.66 Raymond, Oliver. The art of fishing, on the principle of avoiding cruelty. With approved rules for fishing used during sixty years' practice, not hitherto published in any work on the subject. London. 1866. $16^{\circ}$. pp. xx., 69. Wdcts.

Renauld, L. D., or L. B., pseudon. See Desloges, Louis Camille Auguste.

Ang. 18.76.6 René, A., and Liersel, C. Traité de la pêche à la ligne et au filet dans les rivières et dans les étangs. Contenant toutes les lois y compris l'ordonnance du Io août 1875. Paris. [i 876.] I $8^{\circ}$. Wdcts.

An edition appeared in 1866.

Ang. 18.33 Rennie, James (d. 1867). Alphabet of scientific angling, for the use of beginners. London. 1833. $24^{\circ}$. Port. of Christopher North and wdcts.

Ang. 18.56 Révoil, Bénédict Henry. Chasses et pêches de l'autre monde. [America.] Paris. I $856.16^{\circ}$. .

The author describes his adventures in the backwoods of America during the years $1841-1849$. The only mention of fishing is found in chapter $v_{\text {., }}$ which contains an account of catching devil-fish.

Ang. 25.10 Révoil, Bénédict Henry. Shooting and fishing in the rivers, prairies, and backwoods of North America. Translated and revised by the Chronicler. 2 vol. London. I 865 . sm. $8^{\circ}$.

Contents :-i. Shooting in North America. - ii. Fishing in North America.

*Ang. I8.87 Reynardson, Charles Thomas Samuel Birch. Sports $\&$ anecdotes of bygone days in England, Scotland, Ireland, Italy, and the sunny south. London. 1887. $8^{\circ}$. Col. front. and $5 \mathrm{col}$. plates.

The title-page is illustrated in colors.

Contains several chapters on fishing.

Ang. 50.77 Rhode Island - Commissioners of inland fisheries. [2d]-IIth annual report of the commissioners, I 872-1882. Providence. 1872-82. 8\%. Maps.

Ang. 50.77 Rhode Island-Commissioners to investigate the practicability of re-stocking the waters of the state with salmon and other misratory fish. Report of the commissioners. [Providence? 1869.] $8^{\circ}$. pp. I6.

River Dove (The). I847. I $6^{\circ}$. See [Anderdon, J. L.].

*Ang. 18.66.2 Roberts, Sir Randal (Howland), 4th bart. The river's side; or, The trout and grayling, and how to take them. London. i 866 . I $6^{\circ}$. Wdcts.

A work by the same author entitled "Trout and grayling," was published in 1860 . 
Ang. 44.78 Roberts, Sir Randal Howland, 4th bart. The silver trout, and other stories. London. I $888 . \mathrm{sm} .8^{\circ}$.

Contents:- The silver trout; a legend of the river's side. - The man with the green box. - Trout-fishing in the Rhenish provinces. - A day amongst the pike. - The philosophy of angling. - The famous Waterloo run of $1866 .-$ The big stag of the glen. - A "sow jagd." - The philosophy of shooting. The cruise of the " Sprite."

"Most of the stories have appeared in the Field and Land and water."

Ang. I.38 Robertson, H. R. Life on the upper Thames. London. $1875.4^{\circ}$. Front., plates, and vigns.

"Spinning for troul at a weir," pp. 28-36; "Net-mending," pp. 5760; “Perch-fishing," pp. 99-101 ; " Gudgeon-fishing," pp. 130-134; " Dibbing for chub," pp. 146-152; "Putling down grig-weels," pp. I73-175; "Eel-bucks," pp. I 76-182; "Fisherman's fireside," pp. 191-193.

The illustrations are from drawings by the author.

Ang. 39.29 Robertson, John, of Leith. Angling streams and angling quarters in the Scottish lowlands; with plain directions to trout fishers. Edinburgh. I 859 . I $6^{\circ} .9$ maps.

Ang. 39.30 Robertson, John, of Leith. The hand-book of angling for Scotland and the border counties, embracing the practical experience of thirty years' fishing. London. I86I. I $6^{\circ}$. Map.

A modification of his "Angling streams and angling quarters in the Scottish lowlands."

Ang. 49.46.3 Robinson, Philip. Fishes of fancy; their place in myth, fable, fairy-tale, and folk-lore. With notices of the fishes of legendary art, astronomy, and heraldry. London. I883. $8^{\circ}$. pp. vi., 93. (London, Eng. - International fisheries exhibition, 1883 . [The fisheries exhibition literature, iii. I.])

Also another edition.

I.2823 Romanes, George John. Animal intelligence. New I.2823 York. I 883. I $2^{\circ}$. Wdcts. (The InTERNAtional scientific series, 44.) 2 cop.

"Fish," pp. 24I-253.

Ang. 46.14 The same. 3d ed. London. I883. sm. $8^{\circ}$. Wdcts. (Ditto, 41.)

*Ang. 18.36.2 Ronalds, Alfred. The fly-fisher's entomology. Accompanied by a few observations and instructions relative to trout-and-grayling fishing. London. $1836 . \quad 8^{\circ} . \quad 19$ col. plates.

Plate 19 is used as a frontispiece.

" The author, having felt the little utility of graphical illustrations unaccompanied by colour, has been induced to paint both the natural and artificial fly from nature, to etch them with his own hand, and to colour, or superintend the colouring of each particular impression." - Preface.

The artificial flies are arranged on the same plates with the natural ones which they imitate. 
*Ang. 18.36.3 Ronalds, Alfred. The fly-fisher's cntomology, etc. 2d ed. London. 1839. So. Front. and 19 col. plates.

A colored frontispiece representing a trout and a grayling has been added. to this edition.

*Ang. 18.36.5 The same. 4th ed., corrected. London. I 849 . $8^{\circ}$. Front. and 19 col. plates.

The illustrations are the same as those of the previous edition.

*Ang. 18.36.8 The same. 7th ed. London. I868. $8^{\circ}$. Front. and 19 col. plates.

A new frontispiece and new plates, which vary slightly from the old, appear in this edition. It also contains a new preface signed "Piscator," by whom the work has been revised and improvecl.

Ang. I.I5 Rondelet, Guillaume. Libri de piscibus marinis, in quibus veræ piscium effigies expressæ sunt. [Pars i.]; -Universæ aquatilium historiæ pars altera. 2 pt. Lugduni, apud Matthiam Bonhomme. 1554-55. fo. Port. and wdcts.

Cited by Walton in his "Complete angler."

46.5I Rondelet, Guillaume. L'histoire entière des poissons, composée premièrement en latin; maintenant traduite en françois [par Laurent Joubert]. 2 pt. in I vol. Lion, par Macé Bonhome. I $55^{8}$. 1. $8^{\circ}$. Port. and wudcts.

Imperfict: - title-page of pt. ii. wanting.

"Cette trarluction est un peu recherchée que l'original latin; l'un et l'autre sont remarquables par la belle exécution des gravures sur bois." - Brunet.

Ang. 44.80 Rooper, George. Flood, field, and forest. With illustrations; the etchings by Cecil Boult. London. I 869. sm. $8^{\circ}$. Front., plates; and wdcts.

Contents :- Autobiography of the late Salmo Salar, Esq. - A fox's tale. Bolsover forest. - The bagman.

The two first of these litlle works appeared anonymously in 1867 .

*Ang. 44.84 The same. 5th ed. With illustrations by G. Bowers and J. Carlisle. London. [I884.] i $6^{\circ}$. Front., plates, and wdcts.

*Ang. 18.70.3 Rooper, George. Thames and Tweed. London, etc. *Ang. 18.70.4 [1 870.$]$ sm. $8^{\circ}$. (2 cop.)

The author has " jotted down such precepts and such information as appear, after a long, if not extensive practice of the art of angling, to be best worth noting."

Ang. 47.47 Roosevelt, Robert Barnwell. Fertility in hybridization. [Salem. I 885.] $8^{\circ}$. pp. 6.

"From the Proceedings of the American association for the advancement of science, vol. xxxiii., I 884 ."

*Ang. 47.22 [Roosevelt, Robert Barnwell.] Game fish of the northern states of America and British provinces. By Barnwell [pseudon.]. New York. I862. I $2^{\circ}$. Widcts. 
34.54 Roosevelt, Rcbert Barnwell. The game fish of the northern states and British provinces. With an account of the salmon and sea-trout fishing of Canada and New Brunswick, with simple directions for tying artificial flies, etc. New York. I 865 [cop. I 862]. I 20. Wicts.

Imperfect: - pp. 323, 324, wanting.

The Ist edition with a new title-page.

Ang. 47.23 The same. New York. I 866 [cop. I 862]. I $2^{\circ}$. Wdcts.

Ang. 47.24 The same. New York. I 884. I $2^{\circ}$. Port., plates, and wdets.

"A great deal of fresh matter has been added, and the information and directions have been brought down to the present time. The portion relating to the propagation of fish has been entirely rewritten." - Preface.

Ang. 18.65.7 Roosevelt, Robert Barnwell. Superior fishing; or, The striped bass, trout, and black bass of the northern states. Embracing full directions for dressing artificial flies with the feathers of American birds, an account of a sporting visit to Lake Superior, etc. New York. I 865. $12^{\circ}$. Wdcts. and map.

Ang. I8.65.8 Roosevelt, Robert Barnwell. Superior fishing; or, The striped bass, trout, black bass, and blue-fish of the northern states. Embracing full directions for dressing artificial flies with the feathers of American birds, an account of a sporting visit to Lake Superior, etc. New York. I $884 . \quad$ I $2^{\circ}$. Portrs., plates, wdits., and map.

An enlarged edilion of the preceding work.

*Ang. 48.I4 Roosevelt, Robert Barnwell, and Green, Seth. Fish hatching and fish catching. Rochester, N. Y. I879. I $2^{\circ}$. Wicts. and plan.

VII. I63I Roosevelt, Theodore. Hunting trips of a ranchman. Sketches of sport on the northern cattle plains. Illustrated by A. B. Frost, R. S. Gifford, J. C. Beard, etc. New York, etc. I $885.1 .8^{\circ}$. Front., vigns., and 30 plates.

"Medora edition. 500 copies printed. No. 293."

Contains one page on fishing.

"The seven heads of large game are faithfully copied from the originals, shot by myself. . . . The olher engravings and etchings are for the most part based on photographs taken by myself." - Introiluctory note.

Four of the plates are India-proof impressions of etchings by R. S. Gifford, and seven are Japan-proof impressions of drawings by J. C. Beard.

*Ang. 32.2 The same. vigns., and wdets.

With the exception of the four etchings and one plate omitted, the engrav. ings are the same as in the previous edition, but are not printed as separate plates. 
Ang. 49.46.7 Roper, Richard. Saving life at sea. London. I 883. 8. pp. 23. (LONDON, Eng. - International fisheries exhibition, 1883. [The fisheries exhibition literature, vii. 7.])
Also another edition.

*Ang. 38.4 Roscoe, Edward Stanley. Rambles with a fishing-rod. Edinburgh, etc. $\quad$ I $883 . \quad$ sm. $8^{\circ}$.

Contents :-An autumn ramble in the Salzkammergut and Tyrol.(1873.) Pike-fishing in the Black Forest.(1874.) - In Connemara.(1876.) - Fly-fishing in the Bavarian highlands. (1878.) - A spring ramble in Normandy. (1878.) -A week at a German castle. (I882.) - A diary at Davos. (I882.) - The professional fisherman of the eastern Alps. - On fishing tours abroad. - Seatrout fishing. - Appendix : The clockmakers of the Schwarzwald.

Chapters 9 and ro are reprinted from the Pall Mall gazelte.

Ang. 49.43 Ross, John, jr., of Muchalls, Scotland. Curing and preserving fish in Scotland and its islands. (In HERBERT, David, editor. Fish and fisheries, I 883, $8^{\circ}$, pp. 106-129.)

Ang. 18.67 Routledge, George, and sons, publishers. Handbook of fishing. London, etc. I867. I $6^{\circ}$. pp. iv., 59. Wdcts. (Routledge's sixpenny handbooks.)

Roxby, Robert, and Doubleday, Thomas. The fisher's garland for 1821, etc. See Fisher's garland (The). I82I, etc. $8^{\circ}$. Note.

Ruddiman, Thomas. A collection of scarce, curious, and valuable pieces, both in verse and prose. See Collection $(\mathrm{A})$ of scarce, curious, and valuable pieces. 1785 . $12^{\circ}$.

Ruddiman, Walter. A collection of scarce, curious, and valuable pieces, both in verse and prose. See Collection (A) of scarce, curious, and valuable pieces. I773. I $2^{\circ}$.

*Ang. I.3 Rumph, Georg Everhard. Thesaurus imaginum piscium testaceorum, quales sunt cancri, echini, \&c., ut \& cochlearum; quibus accedunt conchylia, conchæ univalviæ \& bivalviæ, denique mineralia. Lugduni Batavorum. I7II. fo. pp. (4), 15, (8). Engr. title-page, vigns., port., and 60 plates.

A Latin translation of his " D'Amboinsche rariteitkamer."

Ruses innocentes (Les). I660. $4^{\circ}$. See [Fortin, François].

Ang. 49.48 Russel, Alexander (1814-1876). The salmon. Edinburgh. I $864.8^{\circ}$.

Treats of the natural history of the salmon, and of the salmon fisheries of Great Britain.

"Portions of this volume have appeared in the Quarterly review, Blackwood's magazine, the Edinburgh review, and the Scotsman." - Note. 
*Ang. I6.96. II [S., J.] The complete fisher, or, The true art of angling; being a clear and speedy way of taking all sorts of fresh water fish. To which is added an account of the principal rivers, the fish they produce, and the properest places to angle for them in each river. Revised and corrected by W. Wright and other experienc'd anglers. London. [cir. I750.] $24^{\circ}$. Front. and wdcts.

The first edition of this work with the present title appeared in 1704 .

On the back of the frontispiece is written "P. Burrell. I 768. "

*Ang. 16.96 S., J. The true art of angling; or, The best and speediest way of taking all sorts of freshwater fish. Containing the whole body of angling, and mystery of a compleat angler. London. 1696. $24^{\circ}$. Front. and wdcts.

Attributed to John Sprint, in the sale catalogue of Sir Henry Ellis's library. Westwood and Satchell suggest as the author John Smith, whose " Profit and pleasure united" appeared in I684 with the initials J. S. Certain sentences are nearly identical in both works.

"This work forms one of the marked features of most angling book collections, partly from its merits as a manual, but far more from its rarity." Westrwood and Satchell.

*Ang. r6.96.12 [S., J.] The true art of angling; being a clear and speedy way of taking all sorts of fresh-water fish. To which is added an account of the season and spawning time of each fish, and an account of the principal rivers, the fish they produce, and the proper places to angle for them in each river. London. I770. $\mathrm{sm} .12^{\circ}$.

[S., J.] The innocent epicure. See Innocent epicure (The). 1697. $16^{\circ}$.

Ang. 49.45 Sabine, Lorenzo. Report on the principal fisheries of the American seas; prepared for the treasury department of the United States, and submitted by Thomas Corwin as a part of his annual report on the finances, at the second session of the thirty-second congress. Washington. 1853. $8^{\circ}$.

AR. I76 Another copy.

24.30 Another copy.

Ang. 39.36 St. John, Charles. Short sketches of the wild sports and natural history of the Highlands. New ed. London. I 872 . sm. $8^{\circ}$.

Chapter 6 , and parts of chapters $1,12,13,23,25,29$, treat of fishing.

V. III8 The same. London. I878. $8^{\circ}$. Front. and wedcts.

" The popularity of these sketches has been attested by the sale of seven editions since their first publication. But though the work is admitted to take rank with White's 'Selborne ' and Walton's 'Angler,' no attempt has hitherto been made to illustrate the scenes, anecdotes, and ferce nature so graphically described." - Preface. 
Ang. 38.3 St. John, Ferdinand. Rambles in Germany, France, Italy, and Russia, in search of sport. London. 1853. sm. $8^{\circ}$. Col. front. and 3 col. plates.

The illustrations are chromo-lithographs.

Chapters $I$ and 6 contain a few pages on trout fishing.

Salmonia; or, Days of fly fishing. I 828, etc. See [Davy, Sir Humphry, bart.].

Ang. I8.II Salter, Robert. The modern angler; in a series of letters. $2 \mathrm{~d}$ ed. Oswestry. I8II. sm. I $2^{\circ}$. Front. and wdct.

Imperfect: - pp. 3-10 wanting.

The letters are addressed to the Rev. Morgan Pryse.

Ang. 18.14 Salter, Thomas Frederick. The angler's guide, or, Complete London angler; containing the whole art of angling as practised in the rivers Thames and Lea, and other waters twenty miles round London. Founded on actual experience. With the art of trolling for jack or pike. London. I8I 4. I $6^{\circ}$. Front., plates, and wdets.

*Ang. 18.14.2 Salter, Thomas Frederick. The angler's guide; being a complete practical treatise on angling, containing the whole art of trolling, bottom-fishing, fly-fishing, and trimmer-angling. Founded on forty years' practice and observation. $2 \mathrm{~d}$ ed., with additions. London. I8 I5. $8^{\circ}$. Front., plates, map, and wdcts.

Imperfect: - map of the river Lea wanting.

After page 300 are inserted 6 engraved plates of fishes, which are not mentioned in the "List of cuts."

Ang. I8.14.5 Salter, Thomas Frederick. The angler's guide; being a new, plain, and complete practical treatise on the art of angling for sea, river, and pond fish, deduced from many years practice and observation. 5 th ed., carefully corrected and enlarged, divided into three parts, with an appendix. To which is now first added the author's celebrated treatise on trolling. London. [1823.] $\mathrm{sm} .8^{\circ}$. Front., plates, wdcts., and map.

The frontispiece and one of the plates are aquatints.

The "celebrated treatise on trolling," which appears in this and the following editions, is "The troller's guide," which was first published in I 820 .

Ang. 18.14.6 The same. 6th ed., carcfully corrected and enlarged. London. I 825 . I $2^{\circ}$. Port., plates, wdcts., and maps.

This edition contains many new illustrations.

*Ang. 18.14.7 The same. 7th ed., with the author's last corrections and additions. London. I 830 . I $2^{\circ}$. Port., plates, wdcts., and maps. 
Ang. 18.14.8 Salter, Thomas Frederick. The angler's guide, etc. 8 th ed., with the author's last corrections and additions. London. 1833. I $2^{\circ}$. Port., plates, wdcts., and maps.

The title-page is engraved.

With the armorial book-plate of E. F. Webb.

*Ang. I8.14.9 The same. 9th ed., with the author's last corrections and additions. London. 184I. I $2^{\circ}$. Port., plates, wdcts., and maps.

Ang. I8.16 Salter, Thomas Frederick. The angler's guide, abridged for the use of young anglers; being a complete practical treatise on angling. Containing the art of trolling, fly-fishing \& making, etc. Founded on 40 years experience. London. I8 86. I $6^{\circ}$. pp. xvi,, 80. Front. and wdcts.

Ang. 18.20.3 Salter, Thomas Frederick. The troller's guide; a new and complete practical treatise on the art of trolling, or fishing for jack and pike. To which is added the best method of baiting and laying lines for large eels. London. 1820. sm. $8^{\circ}$. Front. and wdcts.

This .work is also found in the $5^{\text {th }}$ and later editions of the author's "Angler's guide."

Ang. 18.20.4 The same. $2 \mathrm{~d}$ ed., with the author's last corrections and additions. London. I830. I $2^{\circ}$. pp. iv., (2), $8 \mathrm{I}$ t. Front. and wdcts.

With a few ms. marginal notes, containing additional information on the subject.

Ang. I8.20.5 The same. $3 \mathrm{~d}$ ed., with the author's last corrections and additions. London. I84 I. I $2^{\circ}$. pp. iv., (2), $83+$. Wdcts.

The last two editions do not contain the chapters relating to eels.

${ }^{*}$ 14455.38 Saluste, Guillaume DE, seigneur Du Bartas. Devine weekes \& workes; translated by Josuah Sylvester. London. [1608.] sm. $8^{\circ}$. pp. (24), 544, 193, (23). Port. and wdcts.

The title-page is engraved.

"The fifth day of the 'Divine weekes and workes' records the creation of sea and river fish, in the catalogue of which we find some oddities - the "whirlabout,' for instance, the 'physeter,' and the 'smell-strong-many-foot.' "Westrwood and Satchell.

${ }^{*}$ I4451.27 The same. With a compleate collectio of all the other most delight-full workes translated and written by Josuah Sylvester. London. 1633. fo. pp. (30), 657. Portrs., welcts., and plate.

The title-page is engraved.

Ang. I.I3 Another copy.

Imperfecl:- portrait of Sylvester and plate wanting. 
"I4451.28 Saluste, Guillaume DE, seigneur Du Bartas Divine weekes and workes, etc. With additions. London. I64I. fo. pp. (26), 670. Portrs., wdcts., and plate.

Imperfect: - pp. 451-474 wanting.

The title-page is engraved.

1542I.20(i) The same. With additions. London. I64I. (Reprinted in Sylvester, Joshua. Complete works, edited by A. B. Grosart, I $880,4^{\circ}$, i.)

Ang. 45.70 Sannazaro, Jacopo. Actii Synceri Sannazarii opera omnia. Hæc quarta editio ab innumeris mendis expurgata est. Amsterodami. $1648.32^{\circ}$.

Contains five piscatory eclogues, entitled "Phyllis," "Galatea," "Mopsus," "Proteus," "Herpylis." They are considered the most perfect works of the author, an Italian poet, who assumed the name Actius Syncerus.

According to Graesse this edition is very incorrect.

4.I34 Another copy.

Ang. 12.22 Satchell, Thomas. The bibliography of Izaak Walton's Compleat angler. London. I882. sm. $4^{\circ}$. pp. 23.

"An excerpt from the 'Bibliotheca piscatoria' of .Westwood and Satchell, printed for presentation only." " No. 2 I."

I4434.2 Another copy.

"No. 36."

Each copy has the author's autograph on the back of the title-page.

Ang. 17.24 Saunders, James. The compleat fisherman. Being a large and particular account of all the several ways of fishing now practised in Europe, with curious secrets in the art of fishing as well in the sea, as in lakes, rivers, or brooks. More particularly calculated for the sport of angling. Also, an account of the principal rivers, lakes, \&c. in England, and what kinds of fish are found in them. Collected from the best authors and from long experience. London. I $724 . \mathrm{sm}^{2} \mathrm{I} 2^{\circ}$. Plate.

This was reprinted by Smeeton with the title, "The fisherman, or, The art of angling made easy. By Guiniad Charfy."

Schneider, Johann Gottlob. Synonymia piscium. See Artedi (Petri) Synonymia piscium. 1789. $4^{\circ}$.

Ang. 47.28.4 Schomburgk, Sir Robert Hermann. Fishes of British Guiana. 2 pt. London. [18-.] Portrs., engr. titlepages, zedcts., and 6I plates. (In JARDINE, Sir William, bart. The naturalist's library, [18-], $16^{\circ}$, xxxix., xl.) 128.

" Memoir of Schomburgk," i. 15-79. - " Memoir of Burckhardt," ii. 15-

All of the plates but two are colored.

46.59 Also in the edition of 1852 . 
*Ang. 18.40.7 Schreiner, William H. Sporting manual. A complete treatise-on fishing, fowling, and hunting, as applicable to this country; with full instructions for the management of the dog. Philadelphia. I84I. 24. Front. and wdcts.

*Ang. 29.9 Schuylkill fishing company, Philadelphia, Penn. An authentic historical memoir of the company, from its establishment in 1732 , to the present time. By a member [William Milnor, jr.]. Philadelphia. I830. $8^{\circ}$. Front. and portrs.

The portrait of Governor Morris was drawn and engraved by St. Memin.

"Dr. Bethune says of this quaint and scarce book that 'it is an amusing account of a very ancient fishing club founded by a few of the original settlers in Pennsylvania. In the catalogue are names of very high distinction, and the association still exists.' It is the most ancient fishing club that exists." Westrwood and Satchell.

I2384.65 Another issue, without the portrait of Governor Morris. 12384.65.2 Schuylkill fishing company,'Philadelphia, Penn. A history of the Schuylkill fishing company of the State in Schuylkill, I 732-1888. [With an appendix containing "Memoirs of the Gloucester fox hunting club."] Philadelphia. I889. 1. $8^{\circ}$. Portrs., plates, and fac-sims.

"A reprint of Wm. Milnor, jr.'s, history, published in 1830 , with a continuation of the same to 1888 , to which is added a list of members from its formation to the present time." - Preface.

*Ang. 43.I Schwatka, Frederick. Nimrod in the north; or, Hunting and fishing adventures in the Arctic regions. New York. I $885.44^{\circ}$. Port. and wdcts.

Describes sport " in the region north of Hudson's Bay, and in the interior of Alaska."

Ang. 25.8 Scott, Genio C. Fishing in American waters. New York. I 869. 8\%. Front. and wdcts.

Part iv. treats of fish-culture.

34.53 Another copy.

Ang. 25.9 The same. New ed., containing parts six and seven, on Southern and miscellaneous fishes. New York. I $875.8^{\circ}$. Front. and wdcts.

Ang. 49.46.7 Scott, Robert Henry. On storm warnings. London. 1883. $8^{\circ}$. pp. 21. (London, Eng. - International fisheries exhibition, $\mathrm{I} 883$. [The fisheries exhibition literature, vii. 6.])

Also another edition.

Scott, William Henry, pseudon.' See Lawrence, John.

*Ang. 22.12 [Scrapbook; containing Newcastle fisher's garlands, numerous engravings of fish and fishing scenes, including a few cuts by Bewick, and other scraps.] $8^{\circ}$.

With the armorial book-plate of Rev. H. S. Cotton. 
*Ang. 22.I I [Scrapbook; containing Newcastle fisher's garlands, numerous engravings of fish, fishing scenes, etc., prices brought by angling books at sales, newspaper cuttings, and other scraps of angling interest.] $8^{\circ}$.

With the armorial book-plate of Rev. H. S. Cotton.

Contains a manuscript copy of the dedication to King George IV. and the address "to his brother anglers," written by Rev. H. S. Cotton for the transcript of Samuel Gardiner's "Booke of angling or fishing," which he prepared for republication. It is dated 1829 .

Ang. 39.52 Scrope, William. Days and nights of salmon fishing in the Tweed; with a short account of the natural history and habits of the salmon. $2 \mathrm{~d}$ ed. London. I $854 . \quad 1.8^{\circ}$. $W d c t s$. and 2 col. plates.

An appendix contains the Tweed fisheries act, and a short extract describing Young's experiments on the growth of salmon.

The woodcuts are engraved by Samuel Williams, from paintings by Edwin Landseer, William Simson, and E. W. Cooke. The two lithographic plates of salmon appear instead of the thirteen lithographs of the first edition. The first edition, 1843 , is rare.

*Ang. 18.84 [Sears, George W.] Woodcraft; by "Nessmuk." New York. [1884.] i $6^{\circ}$. Port. and wdcts.

Chapter 5 contains "Fishing, with and without flies; some tackle and lures; discursive remarks on the gentle art; the headlight; frogging."

Secrets of angling (The). I8II, etc. See [Dennys, John].

*Ang. 47.8 Seeley, Harry Govier. The fresh-water fishes of Europe. A history of their genera, species, structure, habits, and distribution. London, etc. I 886. So. Front. and wdcts.

Ang. 49.46.2 Senior, William. Angling in Great Britain. London. I 883. 8. $^{\circ}$ pp. (4), 8o. (London, Eng.-International fisheries exhibition, 1883 . [The fisheries exhibition literature, ii. 5.])

Also another edition.

Ang. 18.88 Senior, William. Near and far; an angler's sketches of home sport and colonial life. London. I888. sm. $8^{\circ}$.

"Most of the chapters have been extended and re-cast from articles which have appeared in serial publications."

Ang. 18.95 Senior, William. The sea fisher in foreign parts. (In Bickerdyke, John. Sea fishing, i $895,8^{\circ}$, pp. 42 I-444.)

*Ang. 38.5 Senior, William. By stream and sea; a book for wanderers and anglers. London. I877. sm. $8^{\circ}$.

Contains besides several chapters on fishing in England, "Flying fish and their enemies," "Strange fish," and a description of fishing in the Suez canal.

*Ang. 42.2 Senior, William. Travel and trout in the antipodes; an angler's sketches in Tasmania and New Zealand. London. I 880 . sm. $8^{\circ}$. Wdcts.

Reprinted in part from the Gentleman's magazine and from weekly journals. published in Brisbane. 
*Ang. 18.75 Senior, William. Waterside sketches; a book for wanderers and anglers. London. $1875 . \mathrm{sm} .8^{\circ}$. Front. and wdct.

"Most of the chapters originally appeared in the Gentleman's magazine, but they are reprinted with numerous additions."

46.43 Shaw, George. Pisces. 2 vol. London. I 803-04. Engr. title-pages and 190 plates. (In his General zoölogy, I 803, etc., $8^{\circ}$, iv., v.)

The plates are "engraved principally by Mr. Heath."

*Ang. 47.6 Another copy of the $2 \mathrm{~d}$ vol., bound in $2 \mathrm{pt}$.

Ang. 49.46.4 Shaw-Lefevre, George. Principles of fishery legislation. London. 1883. $8^{\circ}$. pp. 31. (London, Eng.International fisheries exhibition, 1883. [The fisheries exhibition literature, iv. 3.])

Also another edition.

Ang. 49.46.5 Shea, Sir Ambrose. Newfoundland: its fisheries and general resources. London. I 883. $8^{\circ}$. pp. 29. (LoNDON, Eng. - International fisheries exhibition, I 883. [The fisheries exhibition literature, v. 6.])

Also another edition.

Ang. 32.5 Shields, George O. Hunting in the great West. (Rustlings in the Rockies.) Hunting and fishing by mountain and stream. [With an account of a sportsman's trip to Florida.] 5th ed. Chicago, etc. I 888 [cop. I 883]. sm. $8^{\circ}$. Front. and wdcts.

"Caxton edition."

Ist edition, 1883 , with the title, "Rustlings in the Rockies."

*Ang. 18.38.5 Shipley, William. A true treatise on the art of flyfishing, trolling, etc., as practised on the Dove, and on the principal streams of the midland counties; applicable to every trout and grayling river in the empire. Edited by Edward Fitzgibbon. London. I838. I $2^{\circ}$. Front. and vigns.

*Ang. 17.84 Shirley, Thomas. The angler's museum; or, The whole art of float and fly fishing. Carefully collected from actual experience. London. [1784.] sm. I $2^{\circ}$. Port. of Fohn Kirby and vign.

This is sometimes called "Kirby's Angler's museum."

Silvester, Tipping, translator. Piscatio, or, Angling. 1733. $8^{\circ}$. See Ford, Simon.

Ang. 49.46.II Sim, G. The food of fishes, both in fresh and salt water. Prize essay. London. 1884. $8^{\circ}$. pp. 50. (LONDON, Eng. - International fisheries exhibition, I 883. [The fisheries exhibition literature, xi. I8.])

Also another edition. 
*Ang. 18.60.4 Simeon, Cornwall. Stray notes on fishing and natural history. Cambridge [Eng.], etc. I $860 . \mathrm{sm} .8^{\circ}$. Front. and wdcts.

Ang. 49.20 Simmonds, Peter Lund. The commercial products of the sea; or, Marine contributions to food, industry, and art. London. 1879. $8^{\circ}$. Wdcts.

Consists of articles first published in the Art journal, the Technologist, and the Fournal of applied science.

V.7I The same. New York. 1879. I $2^{\circ}$. Wdcts.

IV. 4502 Simms, Rupert. [A bibliography of Izaak Walton.] (In his Bibliotheca staffordiensis, I 894, 8º pp. 489-492.)

*Ang. 39.4I Sixty-one, pseudon. Reminiscences of the Lews; or, Twenty years' wild sport in the Hebrides. 2d ed. London. 1873. sm. $8^{\circ}$. Port., plate, and wdcts.

Published in $187 \mathrm{I}$ with the title, "Twenty years' reminiscences of the Lews."

Contains "Soval fishing and artificial spates," pp. 97-114, and several other pages on fishing.

Ang. 49.46.II Skinner, J. Angling clubs. Prize essay. London. I 884. 8․ pp. 8. (London, Eng.-International fisheries exhibition, 1883. [The fisheries exhibition literature, xi. 20.])

Also another edition.

Ang. 48.27 Slack, James H. Practical trout culture. New York. I872. I $2^{\circ}$. Front. and wdcts.

"Bibliography of fish cullure," pp. 142-143.

Ang. 17.24.2 [Smeeton, George.] The fisherman; or, The art of angling made easy. Containing the most approved methods in use for fishing or angling; likewise remarks on the utility of fish ponds. To which are prefixed an account of several methods of fishing practised in Europe, and a description of the principal rivers, lakes, \&c. in England. By Guiniad Charfy [pseudon.]. 2d ed. London. [1815?] $8^{\circ}$.

This work is a verbatim appropriation, without acknowledgment, from Saunders' "Compleat fisherman." This edition also appears in Nicholas Cox's " Nobleman and gentleman's recreation."

Ang. 3.9 Smiley, Charles Wesley. A list of the published reports of the commissioners [of fish and fisheries] appointed by authority of the various states of the United States. [With other papers relating to the fish commission. Washington. 1883.] 1. $8^{\circ}$. pp. (44).

Bulletin of the United States fish commission, 1883, iii. 85-128.

*Ang. 18.60.5 Smith, Arthur (W.). The Thames angler. London. I 860. sm. $8^{\circ}$. pp. 80. Front. and wdcts.

This is an enlarged edition of the work published by A. W. Smith and M. W. Hallett in 1846 .

"The illustrations are borrowed from Hall's 'Book of the Thames." Westrwood and Satchell. 
*Ang. 18.46.2 [Smith, Arthur W., and Hallett, Marmaduke William.] The Thames angler. By A. W. S. and M. W. H. $2 \mathrm{~d}$ ed. London, etc. $1846.24^{\circ}$. pp. 62 . Front. and wdct.

After the first fly-leaf is inserted a letter from the publisher, C. Farlow, to Greville Fennell, ascribing the authorship as above; also a letter from Hallett to Fennell, and a note by Fennell.

This work, somewhat enlarged, with several pages of dialogue, etc. prefixed and appended, was published under the same title by Arthur Smith alone, in 1860 .

Smith, Charles Hamilton. The class pisces, by Baron Cuvier; with additions by C. H. Smith. I 834. $8^{\circ}$. See Cuvier, Georges, Baron.

34.2I Smith, George. The art of angling. 2 plates. (In his Laboratory, I 799, $8^{\circ}$, ii. 244-312.)

34.21 Also in the edition of 1810 .

Ang. 47.25 Smith, Jerome Van Crowninshield. Natural history of the fishes of Massachusetts; embracing a practical essay on angling. Boston. I 833 . 1 $6^{\circ}$. Wdcts.

"Trout and angling," pp. 319-399.

46.58 Another copy.

Ang. 3.3 [Smith, John Russell.] A bibliographical catalogue of English writers on angling and ichthyology. London. I 856. I $2^{\circ}$. pp. 47 .

This catalogue, which contains 264 works on angling, is founded on the one published by Sir Henry Ellis in I8I I, Pickering's "Bibliotheca piscatoria," published in 1836 , and the catalogue in the appendix to the New York edition of Walton and Cotton's "Complete angler," 1847. It gives for the first time a complete list of the English writers on ichthyology.

$3 \frac{1}{2} \cdot 6 \quad$ Another copy.

*Ang. 3.2 [- $]$ The same. (Appended to BLAKEY, Robert. Historical sketches of the angling literature of all nations, I 856 , I $2^{\circ}$, pp. 293-335.)

$3 \frac{1}{2} .6 \quad$ Another copy.

VII. 2233 [Smith, Joseph W.] Winter talk on summer pastimes. A landsman's log. Methuen, Mass. I883. $8^{\circ}$. pp. (2),63. Port., plates, and wdct.

On fishing, especially at Biddeford Pool, Maine; with a section on the lifesaving service, and on Biddeford Pool as a summer resort. Originally published in the Methuen transcript.

With the running title, "Leaves from a diary."

*Ang. 39.39 Smith, William Anderson. Benderloch; or, Notes from the west Highlands [July 3, I879-May 26, I88I]. 2d ed. Paisley. I 883 . sm. $8^{\circ}$. Map.

Ist edition, 1882 .

Natural history sketches, with occasional paragraphs on fishes.

"Originally printed in the Glasgow evening times."

V. 4304 Another copy. 
VIII. 39I (x) Smith, William Anderson. The best appliances and methods of breaking the force of the sea at the entrance to harbours and elsewhere. (In LoNDON, Eng. - International fisheries exhibition, 1883 . The fisheries exhibition literature, I884, $8^{\circ}$, x. 525-544.)

*Ang. 39.40 Smith, William Anderson. Loch Creran; notes from the west Highlands [June, I88 I - June, I883]. Paisley, etc. $1887 . \quad \mathrm{sm} .8^{\circ}$.

Natural history sketches, with occasional pages on fishes.

Ang. 49.46. I I Smith, William Anderson. Salmon disease; its cause and prevention. Prize essay. London. 1884. $8^{\circ}$. pp. 17. (London, Eng. - International fisheries exhibition, 1883. [The fisheries exhibition literature, xi. 5.])

Also another edition:

Ang. 49.43 Smith, William Anderson. Various methods of oyster culture. - Oyster cultivation in Scotland. (In HERBERT, David, editor. Fish and fisheries, 1883, 80, pp. 17-36.)

VIII. 39I (v) Smitt, Fredrik Adam. The Swedish fisheries. (In London, Eng.-International fisheries exhibition, 1883. The fisheries exhibition literature, I 884, 8०, v. 253-269.)

Snapshot, pseudon. See Clements, Lewis.

Ang. 18.01.2 [Snart, Charles.] Practical observations on angling in the river Trent. By a gentleman resident in the neighbourhood, and who has made the amusement his study for upwards of twenty years. Newark. I801. Sm. I $2^{\circ}$.

Imperfect : 一 half-title wanting.

The preface is signed "C. S."

"Attributed to Charles Snart. The work has become scarce." - Westwood and Salchell.

*Ang. 18.47.6 Soltau, G. W. Trout flies of Devon and Cornwall, and when and how to use them. [London], etc. I 847 . sm. $8^{\circ} .2$ col. plates and wdcts.

One of the plates is used as a frontispiece.

South, Theophilus, pseudon. See Chitty, Edward.

*Ang. 39.5I Speedy, Thomas. Sport in the Highlands and Lowlands of Scotland, with rod and gun. Edinburgh, etc. 1884. $8^{\circ}$. Front., plates, and wdcts.

"Trout-fishing," pp. 75-I Io; "Salmon and salmon-fishing," pp. I I I-I4I.

Ang. 18.39.II Sporting almanack (The), and oracle of rural life, for 1843. 5th year. London. 1843. I $6^{\circ}$. Front., engr. title-page, and plates.

Contains several articles relating to angling.

"The sporting almanack," and "The sporting oracle and almanack of rural life," a continuation of "The oracle of rural life," were united in I 842 to form this publication. 
Spring and summer in Lapland (A). 1864. $8^{\circ}$. See [Wheelwright, H. W.].

*Ang. 49.26 Stacy-Watson, C. The silvery hosts of the North sea; with a sketch of "quaint old Yarmouth." With a prefatory note by the editor of Home words. 2d thousand. London. [I883.] sm. $8^{\circ}$. pp. 94. Front. and wdcts.

VI. 1906 Starbuck, Alexander. History of the American whale fishery, from its earliest inception to the year 1876 . Waltham, Mass. I878. $8^{\circ}$. pp. (2), 768. 6 plates.

Ang. 50.2 The same. 6 plates. (Appended to UNITED STATES - Commission of fish and fisheries. Report for I $875-76,8^{\circ}$, pp. I-768.)

45 $\frac{1}{2} \cdot 79$ Another copy.

Ang. 28.4 Steele, Thomas Sedgwick. Canoe and camera; a two hundred mile tour through the Maine forests. New York. I880. $8^{\circ}$. Front., wdcts., portrs., and maps.

Contains a few paragraphs relating to fishing.

15373.24 The same. 3d ed., revised. New York. 1882 [cop. 1880]. 8 . Front., zedcts., portrs., and map. Imperfect: - map in pocket wanting.

Ang. 28.5 Steele, Thomas Sedgwick. Paddle and portage, from Moosehead lake to the Aroostook river, Maine. Boston. I882. $8^{\circ}$. Front., wdcts., and map.

“Trout stories," pp. 54-59.

"Illustrated from photographs made by the author."

Ang. 25.1I Stephens, Charles Asbury. The Knockabout club in the woods; the adventures of six young men in the wilds of Maine and Canada. Boston. I887 [cop. 188 I ]. sm. $4^{\circ}$. Illustr.

Contains a few pages on fishing.

*Ang. 28.ro Stevens, Charles Woodbury. Fly-fishing in Maine lakes; or, Camp-life in the wilderness. Boston, Rand, Avery, \& co. I88I [1880]. 24. Diagr.

Ang. 28.10.2 The same. [New ed. With supplementary pages.] Boston, A. Williams \& co. I88I. sm. $8^{\circ}$. Col. front. and diagr.

The frontispiece contains six illustrations of flies.

Ang. 28.II The same. [3d ed.] Boston. I 884. sm. $8^{\circ}$. Front., plates, and vigns.

A new chapter and numerous illustrations have been added, but this edition does not contain the illustrations of flies.

VII. $426^{\mathrm{a}}$ Another copy. 
*Ang. I8.7I Stewart, William C. A caution to anglers; or, "The practical angler" [by W. C. Stewart], and "The modern practical angler" [by Henry Cholmondeley-Pennell] compared. With remarks upon the decrease of trout and proposed remedies. Edinburgh. 1871. I $6^{\circ}$ pp. iv., 56.

Portions of this work were originally published in the Field.

The author wishes to show " that the similarity is almost entirely confined to the title, and that no two systems of fly-fishing could be more different than those advocated "' by Mr. Pennell and himself.

*Ang. 18.57.5 Stewart, William C. The practical angler; or, The art of trout-fishing, more particularly applied to clear water. Edinburgh. 1857. I $6^{\circ}$. Wdcts.

Three editions were published in 1857 .

*Ang. 18.57.8 The same. 4th ed., revised and enlarged. Edinburgh. I 861 . I $6^{\circ}$. Wdcts.

This is the last edition which was published under the author's supervision.

*Ang. 18.57.II — The same. 7th ed. Edinburgh. 1877. I $6^{\circ}$. $W d c t s$.

Ang. 49.46. I I Stirling, J. The propagation of the salmonidæ. Prize essay. London. 1884. $8^{\circ}$. pp. I7. (LoNDON, Eng. -International fisheries exhibition, 1883. [The fisheries exhibition literature, xi. I.])

Also another edition.

Ang. 18.47.8 Stoddart, Thomas Tod. The angler's companion to the rivers and lochs of Scotland. Edinburgh, etc. I 847. I $2^{\circ}$. Front., col. plate, and wdcts.

Imperfect:- map wanting.

With the armorial book-plate of Samuel T. Tisdale.

Treats chiefly of trout and salmon, and contains a description of angling stations.

Ang. 18.47.9 The same. 2d ed. Edinburgh, etc. 1853. sm. $8^{\circ}$. Front., col. plate, wdcts., and map.

Ang. 18.66.5 Stoddart, Thomas Tod. An angler's rambles, and angling songs. Edinburgh. I 866. sm. $8^{\circ}$. Vign.

Some of the poems are reprinted from his "Songs and poems," I839, and several of the prose sketches originally appeared in a weekly sporting paper, published in London.

Ang. 18.37.7 Stoddart, Thomas Tod. Angling reminiscences, [in the form of a dialogue]. Edinburgh, etc. I837. I $6^{\circ}$. Front., vigns., and plates.

*Ang. 18.35.6 Stoddart, Thomas Tod. The art of angling as practised in Scotland. 2d ed. Edinburgh, etc. I836. I $6^{\circ}$. Wdcts.

Ist edition, 1835 . 
Ang. 45.72 Stoddart, Thomas Tod. Songs and poems; in three parts. Edinburgh. I $839.8^{\circ}$.

" Angling songs," pp. 3-99.

"The angling songs are 57 in number and some of them of great merit." -Westwood and Satchell.

Ang. 48.28 Stone, Livingston. Domesticated trout; how to breed and grow them. [With appendices.] Boston. 1872 . sm. $8^{\circ}$ or $12^{\circ}$. Front. and wdcts.

" Books on fish culture," pp. 336-342.

Ang. I.28 Storer, David Humphreys. A history of the fishes of Massachusetts. Cambridge, etc. I $867 . \quad 4^{\circ}$. 39 plates.

"From the Memoirs of the American academy of arts and sciences," with the original paging.

46.15 The same. Cambridge, etc. I $867.4^{\circ} .39$ plates.

"Reprinted from the Memoirs of the American academy of arts and sciences," with new paging.

Storer, David Humphreys. Reports on the ichthyology and herpetology of Massachusetts. Plates. (In MASSACHUSETTS - Zoölogical and botanical survey. Reports on the fishes, reptiles, and birds of Massachusetts, I 839, $8^{\circ}$, pp. 1-253.)

Ang. 47.47 Storer, Horatio Robinson. Observations on the fishes of Nova Scotia and Labrador, with descriptions of new species. [Boston. I 850.] $8^{\circ}$. pp. 24 . Plates.

"From the Boston journal of natural history, Oct. 1850," vi. 247-270.

V. 440 Another copy.

Ang. 50.2.4(7) Streets, Thomas Hale. Contributions to the natural history of the Hawaiian and Fanning islands and Lower California, made in connection with the United States north Pacific surveying expedition, I 873-75. Washington. 1877. $8^{\circ}$. (U. S. national museum. Bulletin, 7.)

VIII. 39(7) Another copy.

I22.23 The same. Washington. 1877. (In SмITHSONIAN miscel. coll., I878, $8^{\circ}$, xiii. 7.)

*Ang. 46.20 Swainson, William. The natural history of fishes, amphibians, \& reptiles, or monocardian animals. 2 vol. London. I838-39. I $6^{\circ}$. Wdcts. (LARDNER, Dionysius. Cabinet cyclopædia. Nat. hist.)

The tille-pages are engraved.

47.136 Another copy.

Sylvester or Silvester, Joshua, translator. Bartas, his devine weekes \& workes. See Saluste, Guillaume DE, seigneur Du Bartas.

Systema agriculturæ. I681. fo. See [Worlidge, John]. 
Talfourd-Chater, F. J. See Chater, F. J. Talfourd.

Ang. I.45 Tanner, Zera L. Report on the construction and outfit of the U. S. fish commission steamer Albatross. Washington. I $885.44^{\circ}$. Front., wdcts., and plates.

" From the Annual report of the commissioner of fish and fisheries for I883."

The section "Steam machinery and mechanical appliances," is by G. W. Baird.

Tanner, Zera L. Report on the work of the U. S. fish commission steamer Albatross. 1885. $8^{\circ}$. See United States - Commission of fish and fisheries.

Ang. 46.16 Taylor, John Ellor. Nature's byepaths; a series of recreative papers in natural history. $2 \mathrm{~d}$ ed. London. [1882.] sm. $8^{\circ}$.

"The following chapters have been either contributed to magazines, or are abstracts of lectures delivered to farmers' clubs, etc., during the last twelve years." - Preface.

"The geological dispersion of animals and plants," pp. 164-209; "The Norfolk broads," pp. 235-25I; "The county palatine [Lancashire]," pp. 268290; " Pike-fishing in Norfolk," pp. 303-316.

Ang. 18.00 Taylor, Samuel, angler. Angling in all its branches, reduced to a complete science; being the result of more than forty years practice and strict observation throughout Great Britain and Ireland. In three parts: describing the counties of England, Wales, and Scotland, the rivers which they contain, the fish they produce, and the parts best adapted for angling; a full description of the different kinds of fish taken by angling, a list of artificial flies, etc. London. I 800 . sm. $8^{\circ}$.

With the armorial book-plate of Francis Lloyd.

Ang. 49.46.7 Temple, Capt.—. Seal fisheries. London. I 883. 8. pp. 22. (London, Eng.-International fisheries exhibition, I 883. [The fisheries exhibition literature, vii. 5.]) Also another edition.

Ten years in Sweden. 1865. $8^{\circ}$. See [Wheelwright, H. W.].

Ang. 46.7 Tenney, Sanborn. Natural history; a manual of zoölogy. New York. $1866.8^{\circ}$ or $1.12^{\circ}$. Wdcts.

"Fishes," pp. $3^{18-360 .}$

Thames angler (The). 1846. 24\%. See [Smith, A. W., and Hallett, M. W.].

Ang. 18.53.5 [Theakston, Michael.] British angling flies. London, etc. 1862. I $6^{\circ}$. Wicts. and plates.

This work, without the addenda, was published in 1853 with the title, "A list of natural flies that are taken by trout, grayling, and smelt, in the streams of Ripon."

The illustrations of flies are taken from sketches made from nature by a daughter of the author. 
*Ang. 18.53.6 Theakston, Michael. British angling flies. Revised and annotated by F. M. Walbran. Ripon, etc. [I 883.] sm. $8^{\circ}$. Plates and wodcts.

The editor has added several chapters, and has omitted the "addenda" of the 1862 edition.

*Ang. 40.I Thomas, Henry Sullivan. The rod in India; being hints how to obtain sport, with remarks on the natural history of fish, their culture, and value. $2 \mathrm{~d}$ ed. London. I 88 I. 1. $8^{\circ}$. Wdcts. and 25 plates.

'1st edition, 1873. - "This second edition is nearly half of it a new book." - Preface.

Eight of the lithographic plates are colored.

Eight chapters are devoted to the mahseer, the great fresh water game-fish of India.

Ang. 49.46.7 Thompson, Sir Henry (b. 1820). Fish as food. London. 1883. $8^{\circ}$. pp. 32. Wdcts. (LoNDON, Eng.International fisheries exhibition, 1883. [The fisheries exhibition literature, vii. I.])

Also another edition.

*Ang. I.50 Thompson, Maurice. Bow-shooting. Wdcts. (In MAYER, A. M., editor. Sport with gun and rod, [cop. I 883], 8, pp. 854-879.)

Thompson, William Gill: The fisher's garland for 1822, etc. See Fisher's garland (The). I821, etc. $8^{\circ}$. Note.

Ang. 39.15 Thorne, James. Rambles by rivers. With numerous wood-cuts from the drawings of the author. 4 vol. in 2. London. r 844-49. sm. $\mathrm{r}^{\circ}$. Wdcts.

Contents: $-\left[\mathbf{i}_{\text {. }}\right]$ The Duddon. The Mole. The Adur, Arun, and Wey. The Lea. The Dove. 1844. - [ii.] The Avon. 1845. - [iii., iv.] The Thames. 2 vol. 1847-49.

8474.I2 Another copy of vol. [i., ii.].

Ang. I.49 Thornton, Thomas (d. I 823). A sporting tour through the northern parts of England and great part of the Highlands of Scotland; including remarks on English and Scottish landscape, and general observations on the state of society and manners. With engravings from paintings made on purpose by Mr. Garrard. London, etc. 1804. $4^{\circ}$. Front. and 15 plates.

Reviewed by Sir Walter Scott in the Edinburgh review, v. 398-405.

Ang. 38.20 Three in Norway; by two of them. With illustrations from original sketches [by the authors]. Philadelphia. [1882.] sm. $8^{\circ}$. Front., plates, wdcts., and map.

Contains chapters on "Trout" and "Fishing." 
Ang. 49.13 Time's telescope for 1829; or, A complete guide to the almanack. Containing an explanation of saints' days and holidays, with illustrations of British history and antiquities, existing and obsolete rites and customs, sketches of comparative chronology and contemporary biography; astronomical occurrences in every month, comprising remarks on the phenomena of the celestial bodies; and the naturalist's diary, explaining the various appearances in the animal and vegetable kingdoms. [Edited by John Millard.] London. 1829. $12^{\circ}$. Front., ivdcts., and coat-of-arms.

Gives some account of the fishes which are in season each month.

The frontispiece is an engraving, from a painting by David Teniers, the younger.

*Ang. 39.23 Tod, Suetonius M. Trout fishing in the Isle of Man; where to go and what baits to use, with a few practical hints on trout fishing in general. Illustrated with photographs. Douglas, etc. $[1865$.$] i 6^{\circ}$. pp. (6), 62. Front. and plate.

Ang. 38.13 Tolfrey, Frederic, editor. Jones's guide to Norway, and salmon-fisher's pocket companion. London. 1848 . I $6^{\circ}$. Front., illustr. title-page, and $8 \mathrm{col}$. plates.

The plates contain iilustrations of 20 flies, which Westwood and Satchell consider " admirably executed."

"The editor has undertaken, at the request of Mr. Jones, to put together some valuable information afforded him, in the shape of scraps and memoranda, by two or three of his customers who have accomplished a trip to Norway." - Preface.

*Ang. 26.8 Tolfrey, Frederic. The sportsman in Canada. 2 vol. London. 1845. I $2^{\circ}$. Fronts. and plates.

Imperfect: - plate wanting in vol. i.

Contains accounts of several fishing excursions, and an appendix describing the salmon and trout flies and rods best adapted to the North American rivers.

4355.12 Another copy.

Ang. 38.II Tolfrey, Frederic. The sportsman in France; comprising a sporting ramble through Picardy and Normandy, and boar shooting in Lower Brittany. 2 vol. London. ' 1841 . $12^{\circ}$. Fronts. and 10 plates.

Angling subjects are treated of in vol. i. chapters $\mathrm{x}, 3$, and vol. ii. chapters io, I I. Chapter ro of vol. ii. also describes salmon-fishing in Canada.

Ang. I8.68 Trollope, Anthony, editor. British sports and pastimes. 1868. London, etc. I 868 . sm. $8^{\circ}$.

"Fishing," pp. 158-192.

" Reprinted from Saint Pauls magazine, edited by Anthony Trollope."

Trotandot, John, pseudon. See Pulman, George P. R.

True art of angling (The). 1696, etc. See S., J. 
Ang. 18.36 Turton, John. The angler's manual; or, Fly-fisher's oracle. With a brief compendium on bottom fishing. London, etc. $\quad$ I $836 . \quad$ I $6^{\circ}$. pp. viii., 86.

Imperfect: - frontispiece wanting.

Tweed and Don. I860. 16 $6^{\circ}$. See [Locke, James].

Ang. 18.74.3 Two of the essays received on the best means to kill fish (particularly of the larger species) with the least cruelty; for the best essay on which subject a prize was offered by the Baroness Burdett Coutts. Prize not awarded to any of the essays, none being sufficiently practical. Dublin. $1874.8^{\circ}$. pp. $54+$. 3 plates.

Two of the plates are colored lithographs.

The first essay, signed "Kosciusko," gives a description of the basking shark. The second was written by H. Robertson, who advocates the use of the lever harpoon.

Two summers in Norway. I840. I $2^{\circ}$. See [Belton, - ].

Ubique, pseudon. See Gillmore, Parker.

Ang. 50.49 Uhler, Philip Reese, and Lugger, Otto. List of fishes of Maryland. (Appended to MARYLAND-Commissioner of fisheries. Report, 1876, 8०, pp. 67-176.)

Ang. 50.49 Addition to list of fishes of Maryland.

(Ditto, I $877,8^{\circ}$, pp. 57-94.)

Ang. 50.49 Addition to list of fishes of Maryland. (Ditto, I $878,8^{\circ}$, pp. 107-125.)

Ang. 50.2.2 United States - Commission of fish and fisheries. Bulletin. Vol. ii., for 1882 . Washington. I882. $8^{\circ}$. Wdcts.

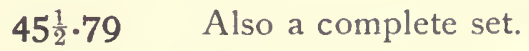

United States-Commission of fish and fisheries. The fisheries and fishery industries of the United States. I 884, etc. $4^{\circ}$. See Goode, G. B., and others.

Ang. 50.2 United States - Commission of fish and fisheries. Report of the commissioner for $1871 / 72-1885$. With supplementary papers. Pt. i.-xiii. Washington. 1873-87. $8^{\circ}$. Plates, plans, wdcts., etc.

Contents:-i. Report on the condition of the sea fisheries of the south coast of New England in 1871 and 1872 . - ii.-xiii. Inquiry into the decrease of the food-fishes. The propagation of food-fishes in the waters of the United States.

Imperfect: - map wanting in pt. i.

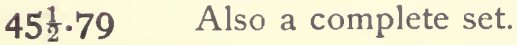


Ang. 50.2.I United States - Commission of fish and fisheries. Report on the work of the U.S. fish commission steamer Albatross, for the year ending Dec. 31, 1883. By Z. L. Tanner, commanding. Washington. 1885. $8^{\circ}$. Plan and 3 plates.

" Extracted from the Annual report of the commissioner of fish and fisheries for $1883 . "$

Other accounts of the work of this steamer are found in the later reports of the commission.

Ang. I.24 United States Japan expedition. 1 852-55. 3 vol. Washington. $1856.4^{\circ}$. Plates, wdcts., maps, etc. (33d cong. 2d sess. Senate. Ex. doc. no. 79.)

Contents:-i., ii. Perry, M. C. Narrative of the expedition of an American squadron to the China seas and Japan in 1852,1853 , and 1854 . 2 vol. 1856 .

iii. Jones, George. Observations on the zodiacal light, from April 2, I853 to April 22, 1855. Made chiefly on board the Mississippi, during her late cruise in eastern seas and her voyage homeward. 1856 .

Ang. 50.2.4 United States national museum. Bulletin. No. 3, 5, 7, 9-1 2, I 4, I5, I 7, I8. Washington. 1876-80. $8^{\circ}$. Plates.

Ang. 3.II Another copy of no. II.

VIII. 39 Also a complete set.

Ang. 50.2.5 United States national museum. Proceedings. Vol. i.iv. 1878-I88I. Washington. I879-82. $8^{\circ}$. Plates, wdcts., and plans.

VIII. I69 Also a complete set.

Universal angler (The). I676. 24. See Walton, Izaak, and others.

*Ang. 29.6 Up de Graff, Thad S. Bodines; or, Camping on the Lycoming. A complete practical guide to "camping out." Philadelphia. I879. $12^{\circ}$. Front., plates, and wdcts.

"A truthful record and the actual experience of two ardent fishermen." Introduction.

Ang. 47.2 I Van Doren, Louis O. The fishes of the east Atlantic coast, that are caught with hook and line. Including The fishes of the east coast of Florida, by S. C. Clarke. New York. I 884. $8^{\circ}$. Front. and wdcts.

"Papers that have appeared in the American angler."

*Ang. 32.6 Van Dyke, Theodore Strong. Flirtation camp; or, The rifle, rod, and gun in California. A sporting romance. New York. 1881. sm. $8^{\circ}$. 
Ang. 18.09 Vanière, Jacques. Fishing. A translation from the Latin of [Prædium rusticum] book xv., upon fish, by John Duncombe. With a brief introduction, and passages from English writers selected as notes, [by Joseph Haslewood]. London. I 809 . sm. $8^{\circ}$. pp. (2), 44.

" The following pages form an article in the 'Censura literaria,' but a few additional copies have been printed for general distribution."

This translation was also reprinted, without acknowledgment, by Daniel, in his "Supplement to the Rural sports," I8r3.

*Ang. 16.62 [Venables, Col. Robert.] The experienc'd angler, or, Angling improv'd; being a general discourse of angling, imparting many of the aptest wayes and choicest experiments for the taking of most sorts of fish in pond or river. London. 1662. $24^{\circ}$. Engr. title-page and other engrs.

With the armorial book-plate of Lt. Col. F. Grant.

The Kingdom's inlelligencer of Sept. 9th, I661, advertises this book as "now newly extant." - "The' engravings of fish are the same as those in [the first four editions of] Walton's 'Compleat angler." " - Westrvood and Salchell.

*Ang. 16.62.3 [- $]$ The same. 3d ed. much enlarged. London. I 668. $24^{\circ}$. Engr. title-page and other engrs.

The name of each fish has been written above the engraving which represents it.

With the armorial book-plate of Lt. Col. F. Grant.

"Ang. 16.62.4 The same. 4th ed. much enlarged. London. 1676. I $6^{\circ}$. Engr. title-page and other engrs.

The plates of fishes are the same as those in the $5^{\text {th }}$ edition of the "Compleat angler," which have been re-engraved in reverse.

*Ang. 6.76.2 Another copy, published as pt. iii. of the "Universal angler."

*Ang. I6.62.6 - The same. London. I825. I $6^{\circ}$. Engrs.

"Memoir," pp. i.-xxiii.

Ang. 16.62.7 — The same. London. I827. I $6^{\circ}$. Engrs.

"Memoir," pp. i.-xxiii.

Same as preceding, with a new title-page.

The last two editions contain reprints of the title-pages of the first edition. The illustrations are, according to Mr. Bartlett, "India impressions of the vignettes engraved on silver," and are mounted in the text.

Ang. 49.9 Verein deutscher fisch haendler. How to cook fish. Recipes for preparing sea and fresh water fish for the table, collected by the verein deutscher fisch haendler. From the German, with additions, by Hugo Mulertt. 2d ed. Cincinnati, Ohio. 1887. 16\%. pp. 64. Vign.

Ang. 50.90 Vermont - Commissioners on the restoration of sea-fish to the Connecticut river. Report of commissioners. Montpelier. 1866. $8^{\circ}$. pp. 35. Diagr. 
Ang. 50.90 Vermont - Fish commissioners. Report of the commissioners for $1867,1871 / 72-1877 / 78.6$ pam. Montpelier, etc. $1867-78 . \quad 8^{\circ}$. Diagrs.

For the years $1875 / 76$, two reports were published, - one by M. C. Edmunds, and the other by M. Goldsmith.

Ang. 50.2 Verrill, Addison Emory. Report on the cephalopods of the northeastern coast of America. 46 plates. (Appended to UNITED STATES - Commission of fish and fisheries. Report for $1879,8^{\circ}$, pp. $21 \mathrm{I}-455$.)

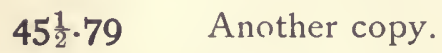

Ang. 50.2 Verrill, Addison Emory. Report upon the invertebrate animals of Vineyard sound and the adjacent waters, with an account of the physical characters of the region. Plates and wdct. (Appended to UNited STATES - Commission of fish and fisheries. Report for $1871 / 72,8^{\circ}$, pp. 295-778.)

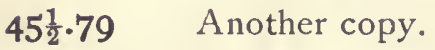

*Ang. 44.3 [Vicary, John Fulford.] A Danish parsonage; [a novel]. By an angler. London. 1884. $\mathrm{sm} .8^{\circ}$.

Includes descriptions of several fishing excursions.

View of the present state of the salmon fishery of Scotland. [1830?] $8^{\circ}$. See [Mackenzie, Murdo].

Ang. 50.91 Virginia - Fish commissioners. Annual report of the commissioners for 1875 . Richmond. 1875. 8. Wdcts.

Ang. 50.9I Virginia - Fish commissioners. Annual reports of the commissioners for $1875-6$ and $1876-7$. With the laws relating to fish and game passed during the session of 1876-7. Richmond. 1877. 8. Wdcts.

*Ang. I.3I Vogt, Karl. Embryologie des salmones. I vol. and atlas of 14 plates, obl. $4^{\circ}$. (In Agassiz, Louis. Histoire naturelle des poissons d'eau douce de l'Europe centrale, $1842,8^{\circ},[$ i. $]$ )

46.5I Three of the plates are colored.

(Atlas, 46.26) Another copy.

W., J. Systema agriculturæ. I68 I. fo. See [Worlidge, John].

*Ang. I8.6I Wade, Henry. Halcyon; or, Rod-fishing with fly, minnow, and worm. To which is added a short and easy method of dressing flies, with a description of the materials used. London. 1861. 5m. $8^{\circ}$. I 2 plates.

Eight of the plates are colored. The plates of flies, "carefully coloured from natural specimens, have been prepared by the writer and his son expressly for this work." - Preface.

This was also issued by the same publishers, without date, as " Rod fishing. in clear water, by fly, minnow, and worm." 
II375.38 Wallace, Edwin R. Descriptive guide to the Adirondacks, and handbook of travel to Saratoga Springs, Schroon lake, lakes Luzerne, George, and Champlain, the Ausable chasm, the Thousand Islands, etc. Revised and corrected by the author. New York, etc. I875. sm. $8^{\circ}$. Front., plates, wulcts., and maps.

Mentions the places where fishing is to be found.

Ang. 29.I The same. 6th ed., revised and corrected by the author. New York, etc. 1878 [cop. 1876]. sm. $8^{\circ}$. Front., plates, wdcts., and maps.

Ang. 49.46.5 Wallem, Fredrik M. Notes on the fish supply of Norway. London. I883. $8^{\circ}$. pp. 31 . Table. (London, Eng. -International fisheries exhibition, I883. [The fisheries exhibition literature, v. 8.])

Also another edition.

Ang. 49.46 Walpole, Spencer. The British fish trade. London. I883. $\quad 8^{\circ}$. pp. (2), 69. (London, Eng. - International fisheries exhibition, 1883 . [The fisheries exhibition literature, i. 1.])

Also another edition.

Ang. 49.46.4 Walpole, Spencer. Fish transport and fish markets. London. I883. 8\%. pp. 34. (LONDON, Eng. - International fisheries exhibition, 1883. [The fisheries exhibition literature, iv. 4.])

Also another edition.

Ang. 49.46.7 Walsh, R. F. On improved facilities for the capture, economic transmission, and distribution of sea fishes, and how these matters affect Irish fisheries. London. I883. $8^{\circ}$. pp. 37. (London, Eng. - International fisheries exhibition, I883. [The fisheries exhibition literature, vii. 4.]) Also another edition.

*Ang. 6.55 [Walton, Izaak. The compleat angler; or, The contemplative man's recreation. Being a discourse of rivers, and fish-ponds, and fish, and fishing, not unworthy the perusal of most anglers. $2 \mathrm{~d}$ ed., much enlarged. London, Marriot. I655.] sm. I $2^{\circ}$. Engrs.

The title-page is wanting, and has been replaced by a fac-simile of the titlepage of the first edition, 1653 .

With the armorial book-plate of Lt. Col. F. Grant, and his autograph.

*Ang. 6.68 [Walton, Izaak. The compleat angler; or, The contemplative man's recreation. Being a discourse of rivers, fish-ponds, fish, and fishing. 4th ed., much corrected and enlarged. London, Marriot. 1668.] $24^{\circ}$. Engrs.

Imperfect: - title-page wanting.

With the armorial book-plate of Lt. Col. F. Grant. 
Ang. 8.10 Walton, Izaak. The compleat angler. London, Bagster. i8 10. I $6^{\circ}$. Engrs.

Imperfect: - pp. 71, 72, and portrait wanting.

This is a reprint of the first edition, but can scarcely be called a facsimile. "Though the plates are in close imitation of their prototypes, there is no attempt at identity in the general getting up of the work." T. Westwood.

Ang. 8.69 Walton, Izaak. The compleat angler; or, The contemplative man's recreation. Being a discourse of fish and fishing not unworthy the perusal of most anglers. [Edited by Alexander Murray.] London, Murray and son. I 869. sm. $8^{\circ}$. (Murray's reprints.)

A reprint of the first edition.

Ang. 8.72 Walton, Izaak. The compleat angler; or, The contemplative man's recreation. Being a discourse of fish and fishing not unworthy the perusal of most anglers. [Edited by Alexander Murray.] London, Murray and co. 1872. sm. $8^{\circ}$. (Murray's reprints.)

A reprint of the first edition.

*Ang. 8.76 Walton, Izaak. The complete angler; or, The contemplative man's recreation. Being a fac-simile reprint of the first edition, published in 1653 . London, Stock. 1876. sm. $8^{\circ}$. Wdcts.

"Some of the types used in printing the first edition are altogether obsolete. . . . these, as well as the sharp vigorous little cuts of fish, and the very tasteful title-page, have been reproduced by a photographic process which is simply infallible." - Preface.

The book, however, is not a photographic fac-simile.

*Ang. 8.80.2 Walton, Izaak. The complete angler; or, The contemplative man's recreation. Being a fac-simile reprint of the first edition, published in 1653 . London, Stock. [ 1880.] I $6^{\circ}$. Wdcts. ([STOCK, Elliot, publisher. Three seventeenth century rarities.])

" 350 copies. No. 286."

Another issue of the reprint published by Stock in 1876 .

Ang. 8.82 [Walton, Izaak.] The compleat angler; or, The contemplative man's recreation. Being a discourse of fish and fishing not unworthy the perusal of most anglers. London, Marriot. I653. [Reprinted, London, Griggs. I 882:] I 60. Wdcts.

A fac-simile of the first edition, produced by a photographic process.

In Satchell's edition of Westwood's "Chronicle of the "Compleat angler" " it is stated that the type has been contracted, thus reducing the size of the pages, and that other variations from the original occur, due to the "touching up " process. 
*Ang. 6.76 Walton, Izaak, and [Cotton, Charles]. The compleat angler; or, The contemplative man's recreation. 2 pt. in I vol. London, Marriot. 1676. 16\%. Engrs.

Contents:- i. A discourse of rivers, fish-ponds, fish, \& fishing; by Izaak Walton. 5th ed., much corrected and enlarged. - ii. Instructions how to angle for a trout or grayling in a clear stream; [by Charles Cotton].

On the first fly-leaf of pt. ii. there is a Ms. table of contents.

This is the last edition of the "Compleat angler" published during Walton's lifetime. The engraved scroll found on the title-pages of the earliest editions is here pasted on, and the plates of fishes have been re-engraved in reverse. Pt. ii. is the first edition of Cotton's work. These two parts, with the work of Venables appended, were also issued under the collective title "The universal angler."

*Ang. 6.76.2 Walton, Izaak, and others. The universal angler, made so by three books of fishing; the first written by Izaak Walton, the second by Charles Cotton, the third by Robert Venables. London, Marriott. 1676. 24\%. Engrs.

Pt. i. is " $5^{\text {th }}$ ed., much corrected and enlarged;" iii. is " $4^{\text {th }}$ ed. much enlarged."

Each of these works was also issued separately.

*Ang. 7.50 Walton, Izaak, and Cotton, Charles. The compleat angler; or, Contemplative man's recreation. Carefully and correctly published from the best editions, with notes by Moses Browne. To which [is] added an appendix. London, Kent. 1750. sm. $12^{\circ}$. Front., plates, and wdcts.

For a criticism of Browne's editing, see Westwood and Satchell's " Bibliotheca piscatoria," p. 220.

*Ang. 7.59 Walton, Izaak, and Cotton, Charles. The compleat angler; or, Contemplative man's recreation. Correctly and accurately published, with notes, by Moses Browne. 7 th ed., much amended and improved. With an appendix. 2 pt. in I vol. (paged contin.). London, Kent. 1759. sm. $12^{\circ}$. Fronts., plates, and wdcts.

Pt. ii. is " 3 d ed., improved."

Iniperfect: - pp. 147-166 wanting.

*Ang. 7.60 Walton, Izaak, and Cotton, Charles. The complete angler; or, Contemplative man's recreation. To which are now prefixed the lives of the authors. [Edited] with notes [by John Hawkins]. 2 pt. in 1 vol. London, Hope. $1760.5 \mathrm{sm} .8^{\circ}$. Front., plates, engrs., and port. of Cotton.

The "Ecloga piscatoria," attributed to Metastasio, is inserted in Ms. at the end.

Most of the plates are dated $\mathbf{1 7 5 9}$.

The life of Walton was written by Hawkins, that of Cotton by W. Oldys. 
*Ang. 7.66 Walton, Izaak, and Cotton, Charles. The complete angler; or, Contemplative man's recreation. To which is now prefixed the lives of the authors. [Edited] by John Hawkins. 2d ed. 2 pt. in I vol. London, Rivington, etc. I $766 . \quad$ sm. $8^{\circ}$. Front., plates, engrs., and port. of Cotton.

The edition of 1760 with a new title-page.

An advertisement describing the establishment of Onesimus Ustonson, dealer in fishing supplies, and an engraved sheet entitled "The anglers assistant," are inserted before the frontispiece.

*Ang. 7.72 Walton, Izaak, and Cotton, Charles. The compleat angler; or, Contemplative man's recreation. Correctly and accurately published by Moses Browne. 8th ed., with all. the songs set to music. Also an appendix. 2 pt. in I vol. (paged contin.). London, Causton. 1772. sm. $12^{\circ}$. Fronts., plates, and wdcts.

Pt. ii. is " 4 th edition improved."

The music is the work of the editor.

*Ang. 7.75 Walton, Izaak, and Cotton, Charles. The complete angler; or, Contemplative man's recreation. To which are prefixed the lives of the authors. [Edited] by Sir John Hawkins. 3d ed. 2 pt. in I vol. London, Rivington, etc. I 775, '74. sm. $8^{\circ}$. Front., plates, engrs., and port. of Cotton.

*Ang. 7.84 Walton, Izaak, and Cotton, Charles. The complete angler; or, Contemplative man's recreation. With the lives of the authors and notes, by Sir John Hawkins. 4th ed., with large additions. 2 pt. in I vol. London, Rivington. 1784. sm. $8^{\circ}$. Front., plates, engrs., wdcts., and port. of Cotton.

In this edition the life of Walton has been enlarged, and a life of Cotton by Hawkins substituted for the one by W. Oldys in the earlier editions. An "Ecloga piscatoria," attributed to Metastasio, has been added to the appendix.

"Ang. 7.92 Walton, Izaak, and Cotton, Charles. The complete angler; or, Contemplative man's recreation. With the lives of the authors and notes, by Sir John Hawkins. 5 th ed., with additions. 2 pt. in I vol. London, Rivington, etc. I 792 . sm. $8^{\circ}$. Front., plates, engrs., wdcts., and port. of Cotton.

The edition of I79I with a new title-page.

The edition of 179 I was revised by J. S. Hawkins, son of Sir John, who found on the margins of his father's copy of the fourth edition "some corrections and additions, which, though not many, have been all made use of, from a wish that the book might receive the advantage of his last corrections." 
*Ang. 7.97 Walton, Izaak, and Cotton, Charles. The complete angler; or, Contemplative man's recreation. With the lives of the authors and notes, by Sir John Hawkins. 6th ed., with additions. 2 pt. in I vol. London, Rivington, etc. 1797. I $2^{\circ}$. Plates and wdcts.

Imperfect: - frontispiece and portrait of Cotton wanting.

Ang. 8.08 Walton, Izaak, and Cotton, Charles. The complete angler; or, Contemplative man's recreation. With the lives of the authors and notes, by Sir John Hawkins. [7th ed., with improvements and additions.] London, Bagster. I 808. $8^{\circ}$. Front., portrs., plates, engrs., and wdcts.

Hawkins' notes have been revised in this edition, and some additions made to them.

*Ang. 8.08.2 The same. [7th ed., with improvements and additions.] London, Bagster. $1808 . \quad 8^{\circ}$. Large paper. Portrs., plates, engrs., and wdcts.

A portrait of Walton has been substituted for the frontispiece, and a colored plate inserted to face page 210 .

On page 7 is pasted a list of the illustrations of the ordinary $7_{\text {th }}$ edition.

*Ang. 8.I5 Walton, Izaak, and Cotton, Charles. The complete angler; or, Contemplative man's recreation. With the lives of the authors and notes, by Sir John Hawkins and the present editor [Henry Ellis. 8th ed.] London, Bagster. I8I5. 8․ Large paper. Portrs., plates, engrs., wdcts., fac-sim., and maps.

Ang. 8.22 Walton, Izaak, and Cotton, Charles. The complete angler; or, Contemplative man's recreation. With the lives of the authors and notes, by Sir John Hawkins. [9th ed. Edited by T. Gosden.] 2 pt. in I vol. (paged contin.). London, Smith. I $822 . \quad 8^{\circ}$. Portrs., plates, vigns., and fac-sims.

With a reprint of the title-page of the first edition.

The plates are all new.

*Ang. 8.23.2 Walton, Izaak, and Cotton, Charles. The complete angler: to which are added an introductory essay [by John Major], the Linnæan arrangement of the various river-fish delineated in the work, and illustrative notes. [Edited by Richard Thomson.] $2 \mathrm{pt}$. in I vol. (paged contin.). London, Major. $1823.16^{\circ}$. Portrs., plates, fac-sims., and wdcts. Most of the plates have the date 1822 .

At the end is pasted a slip of paper on which is written the following acrostic:-

Where silvery streams with rippling music play,

Angling along their banks oft wouldst thou stray,

Losing thyself awhile in pleasant dreams,

Those quainlly simple, prose-poetic streams

Of charming colloquy, refreshing, bright,

Ne'er read, dear honest Angler, save with new delight.

May, 1854. Sarum.

c. V. G. 
*Ang. 8.23 Walton, Izaak, and Cotton, Charles. The complete angler, etc. [Edited by Richard Thomson.] 2 pt. in I vol. (paged contin.). London, Major. I823. I $6^{\circ}$. Large paper. Portrs., plates, fac-sims., and wdcts.

A large paper copy of the preceding edition. The plates are on India paper, mounted, and most of them have the date I822.

*Ang. 8.24.2 Walton, Izaak, and Cotton, Charles. The complete angler; to which are added an introductory essay [by John Major], the Linnæan arrangement of the various river fish delineated in the work, and illustrative notes. [Edited by Richard Thomson.] $2 \mathrm{~d}$ ed. 2 pt. in I vol. (paged contin.). London, Major. I 824. I $6^{\circ}$. Portrs., fac-sims., plates, and wdcts.

*Ang. 8.24 The same. 2d ed. 2 pt. in I vol. (paged contin.). London, Major. 1824 . I $6^{\circ}$. Large paper. Portrs., facsims., plates, and wdcts.

The plates are on India paper, mounted.

*Ang. 8.24.3 Walton, Izaak, and Cotton, Charles. The complete angler. 2 vol. Chiswick, Whittingham. I 824. $24^{\circ}$. Portrs, and signs.

A reprint of Hawkins' 6th edition, 1797.

Ang. 8.25 Walton, Izaak, and Cotton, Charles. The complete angler; or, Contemplative man's recreation. With the lives of the authors and notes, by Sir John Hawkins. London, Dove. I $825.24^{\circ}$. Portrs., engr. title-page, and plates. (English classics.)

On the first fly-leaf is pasted Walton's epitaph, engraved from a fac-simile of his tombstone, and at the end a plate containing the autographs of Walton and Cotton. These engravings appeared in the edition of 1822 .

*Ang. 8.25.2 Walton, Izaak, and Cotton, Charles. The complete angler; or, The contemplative man's recreation. 2 pt. in I vol. (paged contin.). 'London, Pickering. I $825.48^{\circ}$. Front., engr. title-page, and wedcts.

I4434.6 Another copy.

"Ang. 8.26 Walton; Izaak, and Cotton, Charles. The complete angler. 2 vol. Chiswick, Whittingham. I826. $24^{\circ}$. Portrs. and wdcts.

A reprint of Hawkins' 6th edition, 1797.

*Ang. 8.26.2 Walton, Izaak, and Cotton, Charles. The complete angler; or, The contemplative man's recreation. 2 pt. in I vol. (paged contin.). London, Pickering. $1826.32^{\circ}$. Portrs., engr. title-page, and wudts.

The portraits and engraved title-page have the date 1827 . 
*Ang. 8.33 Walton, Izaak, and Cotton, Charles. The complete angler; or, Contemplative man's recreation. With lives and notes by Sir John Hawkins. Edited by James Rennie. Edinburgh, Chambers, etc. 1833. 16 . Port. of Walton, plates, and redcts.

On a fly-leaf at the end is written a sonnet entitled "The trout."

*Ang. 8.35 Walton, Izaak, and Cotton, Charles. The complete angler; to which are added an introductory essay [by John Major], the Linnæan arrangement of the various river fish delineated in the work, and illustrative notes. [Edited by Richard Thomson.] 3d ed. 2 pt. in I vol. (paged contin.). London, Major. I 835 . I $6^{\circ}$. Portrs., fac-sims., plates, and wdcts.

A reprint of the second edition, 1824; with the addition of a portrait of Thomas Wharton.

*Ang. 8.36.2 WaIton, Izaak, and Cotton, Charles. The complete angler; or, The contemplative man's recreation. With original memoirs and notes by Sir Harris Nicolas. 2 vol. (paged contin.). London, Pickering. I 836 ['35-36]. 1. $8^{\circ}$. pp. (16), ccxii., (2) + (4), 436, (32). Portrs., plates, wdcts., and engrs.

With reprints of the original title-pages. An engraved title-page and some of the plates have the date 1832 .

This edition contains the variations of the first five editions.

Each volume has the book-plate of Henry Cooper Key.

*Ang. 1.26 Walton, Izaak, and Cotton, Charles. Index to the original and inserted illustrations contained in the "Complete angler," Pickering, publisher, [1836]; five volumes, with 1026 illustrations, comprising portraits, views, zoölogical plates, original drawings, oil paintings, pen and ink sketches, \&c. Rare, original, and unique. New York. $1866.4^{\circ}$. Portrs.

" 50 copies printed for private distribution. No. 17."

"William Daniell gave the labor of fifteen years to the adornment of these volumes. . . . Many a rare tome has been denuded of its portraits and engravings to enrich this splendid copy. . . . It may well be pronounced the finest copy known!"-Introduction.

Ang. 8.36 Walton, Izaak, and Cotton, Charles. The complete angler; or, Contemplative man's recreation. With lives and notes by Sir John Hawkins. Edited by James Rennie. Edinburgh, Fraser \& co., etc. $1836.16^{\circ}$. Port. of Walton, plates, and wdcts.

A paginal reprint of the edition of 1833 .

*Ang. 8.37 Walton, Izaak, and Cotton, Charles. The complete angler. 2 vol. London, Tilt, etc. $1837.32^{\circ}$. Fronts. (Tilt's miniature classical library.)

A reprint of Walton's $5^{\text {th }}$ edition and of Cotton's Ist, without notes. 
Ang. 8.39 Walton, Izaak, and Cotton, Charles. The complete angler; or, Contemplative man's recreation. With notes and the lives of the authors. London, Lewis. 1839. 1. I $2^{\circ}$. Portrs., plates, fac-sims., and wdcts.

A reprint, with some alteration, of the edition published by Major in 1835 .

Ang. 8.42 Walton, Izaak, and Cotton, Charles. The complete angler; or, Contemplative man's recreation. With notes and the lives of the authors. London, Washbourne. I 842 .

1. I $2^{\circ}$. Portrs., plates, fac-sims., and wdcts.

A reprint of the edition of 1839 .

*Ang. 8.44.2 Walton, Izaak, and Cotton, Charles. The complete angler; or, The contemplative man's recreation. Edited by John Major. 4th ed. London, Bogue, etc. 1844 . I $6^{\circ}$. Portrs., fac-sims., wdcts., and plates.

With a fac-simile of the original title-page.

Nine plates by John Absolon have been substituted for Wale's designs.

*Ang. 8.44 The same. 4th ed. London, Bogue, etc. I 844 . I 6. Large paper. Portrs., fac-sims., wdcts., and plates.

14434.7 Another copy.

Ang. 8.47 Walton, Izaak, and Cotton, Charles. The complete angler; or, The contemplative man's recreation. With notes, a bibliographical preface giving an account of fishing and fishing-books, and a notice of Cotton and his writings, by the American editor [G. W. Bethune]. To which is added an appendix, including the most complete catalogue of books on angling ever printed. 2 pt. in I vol. New York and London, Wiley \& Putnam. I 847. I $2^{\circ}$. Portrs., fac-sims., plates, and wdcts.

Imperfect:- - pp. lxxxv., lxxxvi. of vol. i., containing a fac-simile of the original title-page, wanting.

"For the lover of angling-books, and for the collector especially, there is no edition so useful as this." $-T$. Westroood.

I4434.8 Another copy.

With a fac-simile of the original title-page.

*Ang. 8.5 I Walton, Iraak, and Cotton, Charles. The complete angler; or, The contemplative man's recreation. With a new introduction and notes. 2 pt. in 1 vol. (paged contin.). London, Causton. I85 I. 1 $6^{\circ}$. Portrs., plates, and redcts.

With a reprint of the original title-page.

*Ang. 8.53 Walton, Izaak, and Cotton, Charles. The complete angler. New ed. Edited by "Ephemera" [Edward Fitzgibbon]. London, Ingram, Cooke, and co. 1853. sm. $8^{\circ}$. Front., illustr. title-page, portrs., wdcts., and plates.

With a fac-simile of the original title-page.

A volume of Ingram and Cooke's "Illustrated library." 
Ang. II.I Walton, Izaak, and Cotton, Charles. The complete angler. Edited by Ephemera [Edward Fitzgibbon]. London and New York, Routledge \& sons. [18-.] sm. $8^{\circ}$. Front., wdcts., portrs., and plates.

The title-page is illustrated.

With a fac-simile of the original title-page.

A reprint of the edition of 1853 .

Ang. 8.54 Walton, Izaak, and Cotton, Charles. The complete angler. Edited by "Ephemera" [Edward Fitzgibbon]. $2 \mathrm{~d}$ ed. London, Cooke. I 854 . sm. $8^{\circ}$. Front., illustr. title-page, portrs., plates, and wdcts.

With a fac-simile of the original title-page.

*Ang. 8.56 Walton, Izaak, and Cotton, Charles. The complete angler; or, The contemplative man's recreation. With lives of the authors and notes. Edited by Edward Jesse. To which are added papers on fishing-tackle, fishing stations, etc. by H. G. Bohn. London, Bohn. I 856 . sm. $8^{\circ}$. Portrs., fac-sims., and wdcts.

A volume of "Bohn's illustrated library." This is one of the copies issued without plates.

*Ang. 8.58 Walton, Izaak, and Cotton, Charles. The complete angler. 2 vol. London, Groombridge and sons. 1858. $32^{\circ}$. Fronts.

A reprint of the edition published by Tilt in 1837 .

Ang. 8.59 Walton, Izaak, and Cotton, Charles. The complete angler; or, The contemplative man's recreation. With notes, a bibliographical preface giving an account of fishing and fishing-books, and a notice of Cotton and his writings, by the American editor [G. W. Bethune]. To which is added an appendix including the most complete catalogue of books on angling ever printed. 2 pt. in I vol. New York, Wiley. I 859. I $2^{\circ}$. Portrs., fac-sims., wdcts., and plates.

With a fac-simile of the original title-page.

A reprint of the edition of 1847 .

*Ang. 8.60 Walton, Izaak, and Cotton, Charles. The complete angler; or, The contemplative man's recreation. With original memoirs and notes by Sir Harris Nicolas. $2 \mathrm{~d}$ ed. 2 vol. (paged contin.). London, Nattali and Bond. I 860. 1. $8^{\circ}$. pp. (I6), ccxii., (4) + (4), 436, (32). Portrs., engrs., wdcts., and plates.

With reprints of the original title-pages.-A re-issue of Pickering's edition of 1836 .

The engravings are on India paper, mounted. A rare portrait of Cotton, a proof etching, is inserted in vol. ii.

Each volume has the armorial book-plate of William Harrison, F.S.A.

${ }^{*}$ 14431.33 Another copy. 
*Ang. 8.6r Walton, Izaak, and Cotton, Charles. The complete angler; or, The contemplative man's recreation. With lives of the authors and notes. Edited by Edward Jesse. To which are added papers on fishing-tackle, fishing stations, etc. by H. G. Bohn. London, Bohn. I86r. sm. $8^{\circ}$. Portrs., plates, fac-sims., and wdcts.

With a fac-simile of the original title-page.

The edition of 1856 with a new title-page.

*Ang. 8.66 Walton, Izaak, and Cotton, Charles. The complete angler; or, The contemplative man's recreation. Edited by John Major. 2 vol. (paged contin.). Boston, Little, Brozen, and co. $1866 . \quad 8^{\circ}$ or $1.12^{\circ}$. Portrs., plates, facsims., and wdcts.

" Ioo copies printed."

With a fac-simile of the original title-page.

A reprint of Major's edition of 1844 , with India proof impressions of the plates.

Ang. 8.66.2 Walton, Izaak, and Cotton, Charles. The complete angler. Boston, Ticknor and Fields. 1866. $24^{\circ}$. Portrs. and $w d c t s$.

With a reprint of the original title-page.

From the plates of Bell and Daldy's edition, 1863.

*Ang. 8.67 Walton, Izaak, and Cotton, Charles. The complete angler; or, The contemplative man's recreation. Edited by John Major. Boston, Little, Brown, and co. 1867 [1866]. $16^{\circ}$ or sm. $12^{\circ}$. Portrs., fac-sims., plates, and wdcts.

With a fac-simile of the original title-page.

From the same electrotype plates as Major's edition of 1866 .

14434.9 Another copy.

*Ang. 8.75 Walton, Izaak, and Cotton, Charles. The complete angler. London, George Bell and sons. $1875.16^{\circ}$. Front. and wdcts.

With a reprint of the original title-page.

Ang. 8.75.2 Walton, Izaak, and Cotton, Charles. The complete angler; or, The contemplative man's recreation. With original memoirs and notes by Sir Harris Nicolas. London, Chatto and Windus. 1875. sm. $8^{\circ}$. Portrs., engr. title-page, and plates.

A re-issue of the edition published by Pickering in 1836 .

*Ang. 8.80 Walton, Izaak, and Cotton, Charles. The complete angler; or, The contemplative man's recreation. With notes, a bibliographical preface, and a notice of Cotton and his writings, by the American editor, G. W. Bethune. [With an appendix including his "Waltonian library."] 
New ed., with some additions and corrections from the editor's own copy. 2 vol. in I. New York, Fohn Wiley $\mathcal{E}$ sons. I $880.1 .8^{\circ}$. Portrs., fac-sims., wdcts., and plates.

"Only 100 copies printed. No. $36 . "$

With a fac-simile of the original title-page.

A reprint of the text of the American edition of 1847 .

*Ang. 8.8I Walton, Izaak, and Cotton, Charles. The complete angler; or, The contemplative man's recreation. Edited by John Major. Philadelphia, Lippincott \& co. [1881.] $8^{\circ}$ or $1.12^{\circ}$. Portrs., fac-sims., plates, and wdcts.

"Édition de luxe. 250 copies printed. No. 54."

With a fac-simile of the original title-page.

This edition is a re-issue of Major's editions of 1866 and 1867 , but contains 12 additional plates. The illustrations are on India paper, and the woodcuts are mounted in the text.

*Ang. 8.83 Walton, Izaak, and Cotton, Charles. The complete angler; or, The contemplative man's recreation. Edited by John Major. London, Nimmo and Bain. I $883.8^{\circ}$. Portrs., plates, fac-sims., and wdcts.

A reprint of Major's fourth edition, published in $1844^{\circ}$ The six plates and the portraits of Walton and Cotton are original etchings, and duplicates on laid Japan paper are inserted opposite. The woodcuts are on China paper and are mounted in the text.

*Ang. I2.26 Walton, Izaak. Izaak Walton: his wallet booke. [Newly set forth and adorn'd with sculptures curiously engraven by Joseph Crawhall.] London. 1885. $8^{\circ}$. Colored illustrations.

"Large paper: Ioo copies only. No. I4."

A collection of the songs and poesies contained in the "Compleat angler." The illustrations are all hand colored.

${ }^{*}$ I4434.I4 Walton, Izaak. The lives of John Donne, Sir Henry Wotton, Richard Hooker, George Herbert. [Also "Letters written by George Herbert; with others by John Donne."] 4th ed. London. 1675. I 6 \% . Portrs.

14431.30 Walton, Izaak. The lives of John Donne, Sir Henry Wotton, Richard Hooker, George Herbert, and Robert Sanderson. With notes, and the life of the author, by Thomas Zouch. York. I796. $4^{\circ}$. Portrs. and plate.

With the armorial book-plate of Thomas Palmer.

14434.I6 Walton, Izaak. The lives of John Donne, Sir Henry Wotton, Richard Hooker, George Herbert, and Robert Sanderson. New ed. [With "Reasons of the present judgment of the university of Oxford, concerning the solemn league and covenant, etc. Approved June 1, 1647."] 2 vol. Oxford. 1805 . I $6^{\circ}$. 
Ang. 12.9 Walton, Izaak. The lives of John Donne, Sir Henry Wotton, Richard Hooker, George Herbert, and Robert Sanderson. With notes, and the life of the author, by Thomas Zouch. 2d ed. York. I807. 8\%. Portrs, and plate.

*Ang. I2.ro Walton, Izaak. The lives of John Donne, Sir Henry Wotton, Richard Hooker, George Herbert, and Robert Sanderson; to which is now first added Love and truth. With notes, and the life of the author, by Thomas Zouch. 3d ed. 2 vol. York. I8I7. 8. Portrs. and plate.

14434.I7 Walton, Izaak. The lives of Donne, Wotton, Hooker, r4442.8 Herbert, and Sanderson. With some account of the author and his writings. 2 vol. Boston, etc. I 832. I $6^{\circ}$. ([YounG, Alexander, editor. $]$ Library of the old English prose writers, 5, 6.) 2 cop.

"The present edition, so far as the text is concerned, is an exact copy of Zouch's." - Preface.

14431.3I Walton, Izaak. The lives of Donne, Wotton, Hooker, Herbert, and Sanderson. London. 1853. 8\%. Portrs. (The universal library. Biography, i. I.)

I4434.I8 The same. With some account of the author and his writings by Thomas Zouch. New ed., with notes. Boston. 1860. sm. $8^{\circ}$.

14434.20 Walton, Izaak. Lives of John Donne, Henry Wotton, Richard Hooker, and George Herbert. With an introduction by Henry Morley. London, etc. I $888 . \quad$ sm. $8^{\circ}$. (Morley, Henry, editor. Universal library, 59.)

Ang. 12.25 Walton, Izaak. Waltoniana; inedited remains in verse and prose. With notes and preface by R. H. Shepherd. London. I 878 . $\mathrm{sm} .8^{\circ}$.

I4434.24 Another copy.

Waltonian library (A). I 847 , etc. See $[$ Bethune, G. W.].

Ang. 38.r2 Waring, George Edwin, jr. The bride of the Rhine; two hundred miles in a Mosel row-boat. To which is added a paper on the Latin poet Ausonius and his poem “Mosella," by C. T. Brooks. Boston. 1878. I $6^{\circ}$. Front., wdcts., maps, and plans.

" Reprinted, with additions, from Scribner's monthly."

" Mosella," the Ioth Idyl of Ausonius, includes a description of the fishes and fishing of the Moselle. A portion of it, translated into English verse, is found in Mr. Brooks paper.

I5548.37 Another copy. 
VII. 22I4 Warren, Thomas Robinson. Shooting, boating, and fishing for young sportsmen. New York. I871. I $2^{\circ}$. Front., plate, and wdcts.

"Fishing," pp. 139-165.

Ang. 26.I Watson, Beriah André. The sportsman's paradise; or, The lake lands of Canada. With illustrations by D. C. and Harry Beard. Philadelphia. I $888 . \quad 8^{\circ}$. Front. and wdcts.

Contains a few pages on fishing.

Ang. 49.46.I I Watt, W. The currents, temperatures, and physical conditions of the sea, in relation to reproduction, growth, and migrations of fish. Prize essay. London. 1884. $8^{\circ}$. pp. 20. (London, Eng.-International fisheries exhibition, I883. [The fisheries exhibition literature, xi. 19.])

Also another edition.

Way (A) to get wealth. I676. $4^{\circ}$. See [Markham, Gervase].

Ang. $45 \cdot 76$ Wayth, C. Trout fishing; or, The river Darent. A rural poem. London. I 845 . 1. I $2^{\circ}$. pp. 71 .

*Ang. 18.85 Webster, David, angler. The angler and the loop-rod. Edinburgh, etc. I 885 . sm. $8^{\circ}$. Port., plates, wdcts., and map.

The three plates of flies are colored.

*Ang. 18.86.2 Wells, Henry P. The American salmon fisherman. New York. I 886. sm. $4^{\circ}$. Front., map, and wdcts.

Ang. 18.85.6 Wells, Henry P. Fly-rods and fly-tackle; suggestions as to their manufacture and use. New York. I 885 . sm. $4^{\circ}$. Front. and wdcts.

Ang. 12.23 Westwood, Thomas. The chronicle of the "Compleat angler" of Izaak Walton and Charles Cotton; being a bibliographical record of its various editions and mutations. New ed., with some notes and additions by Thomas Satchell. London. I 883 . $\mathrm{sm} \cdot 4^{\circ}$.

This work contains a record of 97 editions of the "Compleat angler."

I4434.I Another copy.

*Ang. 12.28 Westwood, Thomas. In memoriam; Izaak Walton, obiit 15th Dec. 1683. Twelve sonnets and an epilogue. [London. I 884.] sm. $4^{\circ}$. ff. 16.

Printed on one side of the leaf only.

Ang. 3.5 Westwood, Thomas. A new bibliotheca piscatoria, or, General catalogue of angling and fishing literature; with bibliographical notes and data. London. I 861 . i $6^{\circ}$. pp. 78. 
Ang. 18.80.8 Westwood, Thomas. The scholarly angler, and the Angler's note-book. [London. 1884.] sq. $32^{\circ}$. pp. 6. Published as the first article in the new series of the Angler's note-book.

*Ang. 3.8 Westwood, Thomas, and Satchell, Thomas. Bibliotheca piscatoria, a catalogue of books on angling, the fisheries, and fish-culture; with bibliographical notes, and an appendix of citations touching on angling and fishing from old English authors. London. I 883. $8^{\circ}$.

Imperfect: - pp. i., ii. wanting.

This work is founded upon Westwood's New bibliotheca piscatoria, which appeared in $\mathrm{r} 86 \mathrm{r}$.

DR. 3.308 Another copy.

IV. 2022 Another copy.

Wet days at Edgewood. I884. 8\%. See [Mitchell, D. G.].

*Ang. 18.49.3 Wheatley, Hewett. The rod and line; or, Practical hints and dainty devices for the sure taking of trout, grayling, etc. London. 1849. I $6^{\circ} .9 \mathrm{col}$.plates.

Plate 3 is used as a frontispiece.

" My book may, in some measure, be considered a sequel to Mr. Ronalds's 'Flyfisher's entomology.' "- Introduction.

Ang. 49.46.3 Wheeldon, J. P. Angling clubs and preservation societies of London and the provinces. London. I 883. $8^{\circ}$. pp. 79. (London, Eng. - International fisheries exhibition, 1883. [The fisheries exhibition literature, iii. 2.])

Also another edition.

*Ang. 39.13 Wheeldon, J. P. Angling resorts near London; the Thames and the Lea. London. [1878.] I $6^{\circ}$.

Much of the subject-matter was originally published in Bell's Life in London, of which the author was piscatorial correspondent.

Osmund Lambert in his "Angling literature in England" says of Mr. Wheeldon's work: “His descriptions are as faithful as minute, and display a familiar acquaintance with our angling country near the metropolis."

Ang. 49.46.7 Wheeldon, J. P. Freshwater fishing in Great Britain other than trout or salmon. London. 1883. $8^{\circ}$. pp.ii., 88. (London, Eng.-International fisheries exhibition, 1883. [The fisheries exhibition literature.])

VIII. 39I (iii) Wheeldon, J. P. Practical lessons in the gentle craft. (In LoNDON, Eng.-International fisheries exhibition, I883. The fisheries exhibition literature, I884, $8^{\circ}$, iii. $44 \mathrm{I}-525$.

Ang. 42.I [Wheelwright, Horace William.] Bush wanderings of a naturalist; or, Notes on the field sports and fauna of Australia Felix. By an old bushman. London, etc. I861. $16^{\circ}$.

"River fish and angling," pp. 243-247; "Sea-fish and sea-fishing," pp. 248-257. 
*Ang. 38.2I [Wheelwright, Horace William.] A spring and summer in Lapland; with notes on the fauna of Luleä Lapmark. By an old bushman. London. 1864. sm. $8^{\circ}$.

"These notes have, for the greater part, already appeared in the Field." Preface.

"Fish peculiar to these waters," pp. 156-166.

Ang. 38.24 [Wheelwright, Horace William.] Ten years in Sweden ; being a description of the landscape, climate, domes'tic life, forests, mines, agriculture, field sports, and fauna of Scandinavia. By "an old bushman." London. 1865. $8^{\circ}$. pp. xvi., 592 .

"Sea fisheries," pp. 66-70; "Swedish field sports and fishing," pp. 166202; "Fishes," pp. 468-592.

I. 4366 Whishaw, Frederick J. Out of doors in Tsarland; a record of the seeings and doings of a wanderer in Russia. London, etc. $1893 . \mathrm{sm} .8^{\circ}$. Front. and vign.

Contents:- A Russian village. - In the streets of St. Petersburg. - Butter-time and fasting. - A blackcock tournament. - King capercailzie. - Russian woodcock and Finn ponies. - Solitary snipe. - A week among the snowtracks. - Bruin. - A wolf battue. - The angler in Russian waters. - The tyro on snowshoes. - At the ice-hills.

Ang. 26.13 Whitcher, W. F. Nepigon trout; an Ottawa canoeist's experience on the northern shore of Lake Superior. Montreal. I $887 . \quad$ I $6^{\circ}$ pp. $37 . M a p$ and wdcts. (CANADian PACIFIC RaIlway. Primers, 2.)

Ang. 26.13 The same. Montreal. 1888. I $6^{\circ}$. pp. 37. Map and wdcts. (Ditto.)

Ang. 18.40.3 [White, — . . Sporting scenes and country characters. By Martingale [pseudon.]. London. 1840. $8^{\circ}$. Wdcts.

A portion of these sketches first appeared in the Doncaster gazette. Angling, pp. 273-304.

Ang. 49.32 White, P. Observations upon the present state of the Scotch fisheries, and the improvement of the interior parts of the Highlands. Being an essay given in to the Highland society of Scotland, and to which they were pleased to adjudge their highest prize-medal. for the year 1790 . Edinburgh. I791. Sm. I $2^{\circ}$.

*Ang. 45.79 Whitney, John (b. cir. 1640). The genteel recreation, or, The pleasure of angling; a poem. With a dialogue between Piscator and Corydon. London. I700. $[R e-$ printed 1820.] sm. I $2^{\circ}$. pp. (14), 78.

" 100 copies."

The original edition is rare, "probably owing to its having been printed for the author." 
*Ang. I7.14 Whole art of fishing (The); being a collection and improvement of all that has been written upon this subject, with many new experiments. Shewing the different ways of angling, and the best methods of taking fresh-water fish. To which is added the laws of angling. London. I7I4. sm. $8^{\circ}$. Front.

*Ang. 17.14.2 [Whole art of fishing (The).] The gentleman fisher; or, The whole art of angling. Being a collection and improvement of all that has been hitherto written upon this subject, with many new experiments. Shewing the different ways of angling, and the best methods of taking all kinds of fresh-water fish. To which are added the laws of angling. $2 \mathrm{~d}$ ed. London. I727. sm. $8^{\circ}$. Front.

The first edition was published with the title "The whole art of fishing."

Ang. 49.I Whymper, Frederick. The fisheries of the world; an illustrated and descriptive record of the international fisheries exhibition, 1883. London, etc. [1884.] $4^{\circ}$. Front., plates, wdcts., etc.

VII. 1433 Another copy.

Ang. 49.46.II Wilcocks, James Carrall. The best means of increasing the supply of mussels and other molluscs, oysters excepted, used either for bait or food. Prize essay. London. 1884. $8^{\circ}$. pp. 4I. Maps. (LondON, Eng.-International fisheries exhibition, I 883. [The fisheries exhibitionlitèrature, xi. I6.]) Also another edition.

VIII. 39i(ix) Wilcocks, James Carrall. Improved fishery harbour accommodation for Great Britain and Ireland. Plates. ( ${ }^{n}$ LoNDON, Eng.-International fisheries exhibition, 1883. The fisheries exhibition literature, I $884,8^{\circ}$, ix. I-I I3.)

*Ang. I8.65.12 Wilcocks, James Carrall. The sea-fisherman. Comprising the chief methods of hook and line fishing in the British and other seas, and remarks on nets, boats, and boating. 2d ed., much enlarged, and almost entirely rewritten. London. I 868 . sm. $8^{\circ}$. Plates and wdcts.

Ist edition, 1865, with the title, "The sea-fisherman; or, Fishing pilotage." Wildfowler, psezdon. See Clements, Lewis.

Willett, E: H. Oyster culture. I884. 8\%. See Anson, C. V., and Willett, E. H.

Ang. 17.40.20 Williamson, John, angler. The British angler; or, A pocket-companion for gentlemen-fishers. Being a new and methodical treatise of the art of angling, comprehending all that is curious and useful in the knowledge of that polite diversion; with supplemental discourses. Compiled from approved authors, and above thirty years experience. Lon-" don. 1740. sm. I $2^{\circ}$. Front. and plates. 
Ang. 18.08.2 Williamson, Thomas. The complete angler's vademecum; being a perfect code of instruction on the above pleasing science. Wherein are detailed a great variety of original practices and inventions, with all that can contribute to the sportsman's amusement and success. London. I 808 . 1. I $2^{\circ}$. ro plates.

Westwood and Satchell speak of this work as illustrated with 18 engravings.

Ang. 49.49 Willis-Bund, John William. Salmon problems. London. I885. sm. $8^{\circ}$. Diagrs.

Ang. 46.2I Wilson, Andrew, Ph. D. of Edinburgh. Leaves from a naturalist's note-book. London. I882. I $6^{\circ}$. (The MAYFAIR library.)

Contents :- Science and crime. - Lost and missing. - In some medical byways. - At Jamrach's. - Jelly-fishes. - Threads and thrums in lower life. Whales and their neighbours. - Food and fasting. - Scientific ghosts. - The earliest known life-relic. - Skates and rays. - The autobiography of a barnacle. - Leaves. - The autobiography of a fly. - About kangaroos. - On giants. - The polity of a pond.

*Ang. 18.40 Wilson, James (I795-1856). The rod and the gun; being two treatises on angling and shooting. Edinburgh. I $840 . \quad$ sm. $8^{\circ}$. Plates and wdcts.

Imperfect: - frontispiece and "List of works on angling," wanting.

These treatises were originally published in the 7th edition of the Encyclopædia britannica, and have been enlarged and improved.

Ang. 18.40.2 The same. New ed. Edinburgh. I $844 . \mathrm{sm} .8^{\circ}$. Front., plates, and wdcts.

"List of books on angling," pp. 279-288.

Ang. 1.52 Wilson, John (1785-1854). Angling. [Edinburgh? I 85-.] $4^{\circ}$. pp. (20). Plate.

"From the Encyclopredia britannica, 8th ed.," iii. 146-165.

*Ang. 44.97 Wilson, John (1785-I854). Essays critical and imaginative. [Edited by J. F. Ferricr.] Vol. ii. Edinburgh, etc. I 865 . sm. $8^{\circ}$.

Contents :- Christopher at the lakes. - Tennyson's poems. - Memoir of Sir Henry Blackwood. - American poetry: William Cullen Bryant. - Poetry of Ebenezer Elliott. - On the punishment of death. - Anglimania :- Salmonia [by Sir Humphry Davy]. Twaddle on Tweedside. Stoddart on angling. Our two panniers.

*Ang. 48.35 Wilson, Sir Samuel. Salmon at the antipodes; being an account of the successful introduction of salmon and trout into Australian waters. [3d ed.] London. I 879. sm. $8^{\circ}$. Front. and map.

Originally published in a slightly different form, under the title "The Californian salmon," in the Transactions of the zoölogical and acclimatization society of Melbourne, for 1878 .

At the end is pasted a newspaper cutting from the Academy, Aug. 30, 1879, containing a review of the work by T. T. Stoddart.

Winter talk on summer pastimes. 1883. $8^{\circ}$. See [Smith, J. W.]. 
Ang. 50.95 Wisconsin-Commissioners of fisheries. Ist-9th annual report of the commissioners [for 1874]-1882 (in I vol.). [Madison. I875?]-83. 8. Plates and wdcts.

Ang. 32.4 With rod and line in Colorado waters. Denver. I 884 . sin. $8^{\circ}$. Map and vigns.

Signed "Bourgeois."

Ang. 46.I Wood, John George (I827-1889). The illustrated natural history. With designs by Wolf, Zwecker, Weir, Coleman, etc. [Vol. iii.] London, etc. [I 865 ?] 1. $8^{\circ}$. Front. and redcts.

"Fishes," pp. 196-354.

Ang. I.22 [Worlidge, John.] Systema agriculturæ; the mystery of husbandry discovered. Treating of new ways of tilling, planting, improving all sorts of gardens, orchards, woods \& coppices; also of fruits, cattle, fish, \&c., with an account of the instruments and engines used. To which is added Kalendarium rusticum, or, The husbandmans monthly directions; also the prognosticks of dearth, plenty, \&c., and Dictionarium rusticum, or, The interpretation of rustick terms. 3d ed., corrected and amended, with one section added, and many additions. By J. W. London. I68 I. fo. Engr. title-page, plate, and wdcts.

"Of fishing," pp. 253-262.

Ang. 47.38 Wright, William, surgeon-aurist. Fishes and fishing. Artificial breeding of fish, anatomy of their senses, their loves, passions, and intellects ; with illustrative facts. . London. I858. I $6^{\circ}$. Front. and plates.

"Very anecdotical and interesting." - Westwood and Salchell.

*Ang. 1.32 Yarrell, William. On the growth of the salmon in fresh water. With illustrations of the fish, of the natural size, exhibiting its character and exact appearance at various stages during the first two years. London. I 839 . obl. $4^{\circ}$. pp. (2), 3. Wdcts. and 3 col. plates.

"Incorporated with the third edition of 'British fishes." " - Westwood and Satchell.

The plates were drawn by $\mathrm{C}$. Curtis.

46.32 Yarrell, William. A history of British fishes. 2 vol. London. ${ }_{1836 .} 8^{\circ}$. Wdcts.

"Indispensable in every English angler's library as a work of reference. Yarrell was, besides, an angler, and his work contains many useful hints in connection with the sport." - Westrood and Satchell.

Ang. 47.15 The same. 2d ed. 2 vol. London. I84I. $8^{\circ}$. Wdcts.

Each volume contains the armorial book-plate of Samuel T. Tisdale. 
Ang. 18.60.6 Young angler (The), naturalist, and pigeon and rabbit fancier; with hints as to the management of silkworms, the aquarium, etc. London, etc. I 860 . I $6^{\circ}$. Front. and wdcts.

*Ang. 22.5 Young anglers' companion (The). Giving a description

*Ang. 22.6 of all the different methods of angling, the best baits and tackle, as wcll as the times and seasons for using them. Also a description of trolling and fly fishing. [London. I 8-. . sm. $8^{\circ}$. pp. 26. Col. front. and wdcts. (2 cop.)

The coloring of the frontispiece and of the illustration of the salmon on the title-page, varies somewhat in the two copies.

Published as a sixpenny pamphlet. The last page of the cover contains "Remarks on the seasons most favorable to the angler."

*Ang. 39.42 Young, Andrew. The angler and tourist's guide to the rivers, lakes, and remarkable places in the northern counties of Scotland. To which is added instructions to young anglers. Edinburgh. I $857.24^{\circ}$. Map.

Ang. 47.4I Young, Andrew. The natural history and habits of the salmon; with reasons for the decline of the fisheries, and also how they can be inproved, and again made productive. Also an account of the artificial incubation of the salmon. London. I 854 . I $6^{\circ}$.

*Ang. 39.20 Young, Archibald. The angler's \& sketcher's guide to Sutherland. Edinburgh. I880. I $6^{\circ}$. Map.

Revised and enlarged from a series of papers entitled "An angler's and sketcher's ramble through Sutherland," published in the Scotsman in 1879 . The author was commissioner of Scotch salmon fisheries.

Ang. 49.43 Young, Archibald. Harbour accommodation for fishingboats on the east and north coasts of Scotland; pointing out the localities where harbours are most required, and distinguishing between natural coves or bays which may be converted into good harbours by artificial assistance, and places where the harbours must be cntircly artificial. ( $I n$ Herbert, David, editor. 'Fish and fisheries, I 883, $8^{\circ}$, pp. 65-92.)

*Ang. 49.34 Young, Archibald. Salmon fisheries. (Appended to Ang. 49.33 Holdsworth, E. W. H. Sea fisheries, $1877,16^{\circ}$, pp. 203-300.) 2 cop.

*Ang. 18.65.9 Young, Lambton J. H. Sea-fishing as a sport ; being an account of the various kinds of sea fish, how, when, and where to catch them, in their various seasons and localities. London. I 865 . sm. $8^{\circ}$. Front. and 7 plates.

Contains a brief historical sketch of British fisheries.

*Ang. 18.65.10 The same. 2d ed. London. I872. sm. $8^{\circ}$. Front. and I 3 plates.

A colored frontispiece and five colored plates have been added to this edition. 
I 70 THE BARTLETT COLLECTION OF BOOKS ON ANGLING.

*Ang. 18.40.5 Younger, John. River angling for salmon and trout; with a memoir of the author. Together with a treatise on the salmon, and a list of the Tweed salmon-casts. [Also a descriptive list of the tributaries of the Tweed, for trout anglers; by the editor. 2d ed.] Kelso, etc. $1860.16^{\circ}$. Port. and vign.

"Sketch of the author's life," pp. xi.-xliv.

Ist edition, I840, with the title, "On river angling for salmon and trout, more particularly as practised in the Tweed and its tributaries."

*Ang. I2.20 Zouch, Thomas. The life of Isaac. Walton, including notices of his contemporaries. London. I $823 . \mathrm{sm} .8^{\circ}$. pp. (4), ii., 93. Front., plates, portrs., etc.

This is also found in many editions of Walton's "Lives."

The plates of Gosden's edition of the "Complete angler," 1822, are used here, with others.

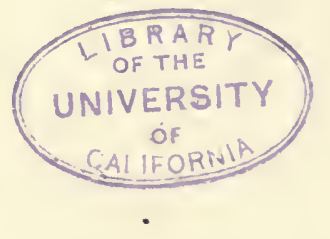




\section{SUBJECT INDEX.}

The references are made to the surname of the author, authors of like surname being distinguished by their initials, and to titles of annnymous works. In cases where chronology is likely to be of interest, the date of publication has been added, if prior to this century. Under place names, books on angling are entered first.

\section{Abyssinia.}

Baker.

Acadia. See Nova Scotia.

Acclimatization of fish.

Maitland.

See also Fish culture.

Adirondacks, N. Y.

Dawson, Halieutics, Hammond, Head. ley, Murray, Northrup, Wallace. (Fishes.)

Mather.

Adriatic Sea. (Fishes and Fisheries.)

Faber.

Adur River, Eng.

Thorne.

Africa, South. (Fishes.)

Pappe.

West. (Fisheries.)

Alaska.

Moloney.

Schwatka.

(Fisheries.)

H. W. Elliott, Hallock.

"Albatross," U.S. F. C. Steamer.

Tanner.

Almanacs.

Angler's, Cox, Illustrated London, Little, New sporting, Sporting, Time's telescope.

Amazon. (Fishes.)

Günther.

America, North.

M. B. Brown \& Co., Hallock, Harris, H. W. Herbert, Lanman, A. M. Mayer, Norris, Révoil, R. B. Roosevelt, Scott, Wells.

(Fishes.)

Gill, Gillmore, Girard, Goode, Hallock, H. W. Herbert, Jordan, R. B. Roosevelt, Van Doren.

America, South. See Chile, Peru.

Andaman Islands. (Fishes.)

Day.

Androscoggin Lakes and River.

Farrar, Gillmore, Halieutics.

Anecdotes.

Baddeley, Badham, Barber, Boosey, ReyAngling. nardson, Wright.

* * General works, on account of their number, have not been indexed.

See Grayling, Salmon, Trout, and other fish.

See also names of countries, rivers, etc. Books on angling are placed first after the names.
Angling. Fïction.

See Fiction.

Angling for ladies.

Compleat servant-maid (1690?).

Angling. French works.

Carpentier, Cussac, Dax, Desloges, Duhamel du Monceau (1769-82), John Fisher, Fortin (1660), Fournival (14th cent.), Karr, Kresz, La Blanchère, S.-A. Lambert, Massas, Matthey, René and Liersel.

Angling. German works.

Alquen, Bierman, Bischoff, Borne, Hartung, Horrocks, Meyer, Moerbe.

Angling. Greek works.

Aelianus, Oppianus.

Angling. Latin works.

S. Ford, Sannazaro, Vanière (trans. I809).

Angling. Poetry and Songs.

See Poetry, Music, Songs.

Angling. Works of the 2 d century. Oppianus.

Works of the $3^{d}$ cent. Aelianus.

Works of the 12 th cent. Neckam.

Works of the 14th cent. Fournival.

Works of the $\mathrm{I} 5$ th cent. Barnes [reprints].

Works of the 16 th cent. Mascall [ 1884 ], Markham [1871], Sannazaro [1648].

Works of the Ith cent. Aldrovandi,

Barker, Barlow, Blagrave, Chetham,

N. Cox, Dennys [reprints], S. Ford,

Fortin, Franck, Innocent epicure,

Markham, Nobbes, Venables, Walton,

Walton and Cotton, Whitney, Wor-

lidge.

Works of the 18 th cent. Best, Brookes, Browne, Cole, Complete family piece, Complete fisherman, Fairfax, Gentleman angler, Howlett, Jacob, J. S., Saunders, Shirley, Vanière, Whole art of fishing, $\mathrm{J}$. Williamson.

\section{Aquarium.}

Buckland, Desloges.

Arctic Regions.

Schwatka.

(Fishes.)

Kumlien.

Ardennes, France.

Lorgh.

Art, Fishes in.

Robinson.

Artificial fies. See Flies, Artificial.

Arun River, Eng.

Thorne.

Assam.

Pollok. 
Associations. See Societies.

Assynt, Scotland.

Hicks.

Astronomy, Fishes in.

Robinson.

Atlantic Ocean. (Fishes.)

Gill.

See also Sea fishing.

Australia.

Senior, Wheelwright, Sir S. Wilson.

See also Neze South Wales.

Austria.

Borne, Horrocks.

- (Fisheries.)

Faber.

(Fishes.)

Faber, Meidinger.

Avon River, Eng.

Thorne.

Axe River, Eng.

Pulman.

Bahamas. (Fisheries.)

Adderley.

(Sponges.)

Kent.

Bait. See Flies, Artificial, and Wormfishing.

Barnacle geese.

Lee.

Barnacles.

Bass.

A. Wilson.

W. Elliott, Gillmore, Halieutics, Hallock, Henshall, A. M. Mayer, R. B. Roosevelt.

Bavaria.

Bischoff, Roscoe.

Belfast Lough. (Fishes.)

Patterson.

Belgium.

Blakey.

Benderloch, Scotland.

W. A. Smith.

Bergen, Norway. (Fisheries.)

Forester.

Bermuda. (Fishes.)

Goode.

Bibliography.

Bartlett, Bethune, Blakey, Bosgoed, R. Clarke \& Co., Daniel, Ellis, H. R. Francis, Gill, Halieutics, O. Lambert, Lenox library, Manley, R. B. Marston, New York (City') - Grolier club, Pickering, Satchell, Simms, Smiley, J. R. Smith, J. W. Smith, IVestwood, Westwood and Satchell, James Wilson.

Biddeford Pool, Me.

J. W. Smith.

Black Forest.

Roscoe.

Blackwater River, $V a$.

Bluefish.

P. Kennedy.

Boats.

R. B. Roosevelt.

Dempster, Holdsworth, Ninni, Omond.

Bottom fishing.

Burgess, Carpenter, Fitzgibbon, J. W. Martin, T. F. Salter.

Brighton aquarium.

Buckland.
British Columbia.

Halieutics, J. K. Lord.

British Guiana. (Fishes.)

Schomburgk.

Brittany.

Halieutics, Kemp, Tolfrey.

Brulé River, Wis. and Mich.

J. I. King.

Burmah.

Pollok.

(Fishes.)

Day.

California.

Mast, Van Dyke.

(Fish culture and Fisheries.)

See California in the List.

(Fishes.)

Girard, Lockington.

Canada.

Adamson, M. B. Brown \& Co., Dashwood, Grand Trunk Railway, Halieutics, Hardy, Harris, H. W. Herbert, W. R. King, Lanman, R. B. Roosevelt, Stevens, Tolfrey, Watson.

-(Fisheries.)

Joncas, Nettle.

See also CANADA in the List.

(Fishes.)

A. L. Adams, W. R. King, R. B. Roosevelt .

(Legislation.)

M. B. Brown \& Co.

(ape of Good Hope. (Fishes.)

Carp.

Pappe.

Lady Campbell, R. North.

Catasauqua, Penn.

H. W. Herbert.

Catskill Mts., N. $Y$.

Lanman.

Crphalopods.

Verrill.

Cetacea.

Jonston, Klein, Patterson.

See also Whales.

Ceylon. (Fishes.)

Bennett.

Chateaugay, $N$. $Y$.

Hammond.

Chile.

Mullen.

(Fishes.)

Girard.

China. (Fisheries.)

$C h u b$

J. D. Campbell.

H. R. Robertson.

Clubs. See Societies.

Cod fishery.

Bowden, A. Fraser, Halieutics.

Cold storage.

Kilbourn.

Colorado.

With rod and line.

- Commercial products of fish.

Bushnan, Simmond.

Conger eel.

Old Calabar.

Connecticut.

Prime.

-(Fish culture and Fisheries.)

See Connecticut in the List. 
Connemara, Ireland.

Roscoe.

Cookery.

Barker, Boccius, Chetham, Compleat servant maid, Cussac, Howlett, Hughes, Verein deutscher fisch haendler.

Cormorants, Fishing with.

Harting.

Cornwall, Eng.

Soltau.

Cotton, Charles.

Alexander.

Crabs.

Blakey, W. B. Lord.

Crayfish.

IV. B. Lord.

Cruelty, Prevention of

Two essays, Raymond.

Crustaceans.

T. Cornish.

Cumberland, Eng.

Chatto, J. Davy.

Curing fish.

D. Herbert, J. K. Lord, Ross.

See also Cold storage.

Darent River, Eng.

Wayth.

Davy, Sur Humphry.

J. Wilson.

Dee River, Eng.

Ayrton.

Delaware.

Philadelphia, Wilmington \& Baltimore R. R.

Denmark.

Vicary.

Derwent River, Eng.

Devil-fish.

Briggs, Wayth.

W. Elliott, Révoil.

Devon, Eng.

Cutcliffe, Soltau.

Dictionaries.

Harewood, Harris, Karr, La Blanchère. Disease.

Brotherton, J. Clark, Cobbold, Huxley, W. A. Smith.

Don River, Eng.

Locke.

Dove River, Eng.

Anderdon, E. Marston, Shipley, Thorne.

Dredging.

Tanner.

Driffield River, Eng.

Mackintosh.

Drum fishing.

W. Elliott.

Duddon River, Eng.

Thorne.

Eel-bucks.

Eels.

H. R. Robertson.

Blakey, Lady Campbell, Cairncross, Davies, Halieutics, Jesse, Old Calabar, T. F. Salter.

England, North of.

F. Francis, Kirkbridge, Mackintosh,

North country angler, Thornton.

Entomology for anglers.

Ronalds.
Erne River, Ireland.

Newland.

Essex County, Mass. (Fishes.)

Goode and Bean.

Europe.

Clements, Roscoe, St. John.

(Fishes.)

Agassiz, Seeley.

Exhibitions. See Fisheries exhibitions.

Fabulous fishes.

Lee, Robinson.

Fanning Islands. (Fishes.)

Streets.

Fiction.

Davies, Dykes, F. Francis, Grant, Jeans, E. L. Peel, Prime, Roberts, Van Dyke, Vicary.

Fire Islands, $N, Y$.

Hawes.

Firth of Forth. (Fishes.)

Parnell.

Fish.

Albin (1794), Aldrovandi (1613), Agassiz, Artedi ( $173^{8}$ ), Badham, Belon (1553), Book of fishes, Brookes ( I 740), Broussonet (I 782), Buckland, Bushnan, Cuvier, Duhamel du Monceau (1769-92), Gouan ( 1770 ), Günther, History of fish, Howes, Jardine, Jesse, IV. Jones, Jonston (1649?), Klein (1740-49), La Blanchère, M'Alpine, Napier, Neckam [I $3^{\text {th }}$ cent.], Oppianus (1597, etc.), Prouty, Rondelet (I554-55), Shaw, Swainson, Tenney, Watt, Wood, Wright.

See also names of fishes and names of places.

Fish, Acclimatization of.

Maitland.

Fish as food.

Howes, W. S. Mitchell, Sir H. Thompson.

See also Cookery.

Fish commissioners' reports.

Smiley.

Fish culture.

Ackerhof, Albin (1794), American angler, American fish culturists' association, American fisheries society, Ashworth, Bierman, Boccius, Buckland, Central fishcultural society, Chambers, Coste, Day, Desloges, Dubravius (1671), Edwards, Esdaile, F. Francis, Fry, Garlick, Godenier, S. Green, Haime, Halieutics, D. Herbert, Hoare, Hogg, Jacobi, Marsh, R. B. Marston, Meyer, R. North (1713), Peard, Piscarius, Pollard, R. B. Roose velt and Green, G. C. Scott, Wright.

See also Fish-ponds, Lobster culture, Oy's. ter culture, Trout culture, ctc.

See also Great Brilain, linited States, etc., and in the List see CANADA, Great Britain, Unitel States, and the States under their names.

Fish, Curing. See Curing fish.

Fïsheries.

W. M. Adams, American fisheries society, Bertram, Bierman, Cornish, Cussac Dubravius (167I), Duhamel du Mon ceau (1769-92), Fortin (I660), F. 
Francis, Fryer, García Solá, Great fisheries of the world, D. Herbert, Holdsworth, Huxley, W. Jones, Karr, London, Eng. - International fisheries exhibition, Meunier, Morris, Mundahl, Philadelphia, Pollock, Practical fishermen's congress, Procter, Rau, Simmonds, Smiley, Two essays, Walsh, Watt, Whymper.

See also Cod, Herring, Mackerel, Menhaden, Pilchard, Salmon, Smelt, Swordfish, Whale.

See also Sea fishing, Trawling.

See also names of countries and places, and, in the List, CANADA, GREAT Britain, United States, and the States under their names.

Fisheries exhibitions.

Berlin, Lankester, London, Eng. - International fisheries exhibition, Philadelphia, Pa. - International exhibition, Fishermen. Whymper.

W. M. Adams, Alfred Ernest Albert, Bertram, De Caux, Halieutics, Levi, Ninni, Roscoe.

Fishes, Blind.

Putnam.

Fishes, Food of. See Food of fishes.

Fishes in art.

Robinson.

Fishes in astronomy.

Robinson.

Fishes in heraldry. See Heraldry.

Fishes, Intelligence of.

Romanes.

Fishes, Large.

Meunier.

Fishes, Pain in.

Bentley.

See also Cruelty, Prevention of.

Fishes, Parasites of.

Cobbold.

Fishes, Symbolical representation of. Blakey, Camerarius.

Fishes, Transportation.

Walpole.

Fish-hooks.

B. Phillips.

See also Tackle.

Fïh-lines. See Tackle.

Fïsh-markets.

Cayley and Bridgman, Halieutics, Walpole.

Fish-pond's.

Boccius, Buckland, Completc grazier (1776), Cussac, Dubravius (I671), Halieutics, Hoare, Markham (I676), Marshall, Mascall (I590), R. North (I7I3, eti.).

Fishwives.

Blakey.

Flies, Artificial.

Aldam, Arundo, Bainbridge, Blacker, Bowlker (1786, etc.), Cairncross, Carroll, Cartwright, Chitty, Capt. Clarke, Complete fisherman (I780? etc.), Sir H. Davy, Dick, Evans, Fitzgibbon, Fly-fishing, Fly maker's handbook, T. Ford, F. Francis, Grey Drake, Halford, Horrocks, Jackson, Kirkbridge, Lakeland, Little, Massas, New- land, Norris, Orvis and Cheney, J. Peel, Pennell, Pritt, Pulman, Ronalds, R. B. Roosevelt, T. F. Salter, Shipley, Soltau, Stevens, S. Taylor, TheakFloat fishing.

ston, Tolfrey, Wade, Webster.

Filorida.

Hallock, Henshall.

(Fishes.)

S. C. Clarke.

Flying-fish.

Senior.

Folk-lore.

Robinson.

Food of fishes. Forests.

Braithwaite, Day, Sim.

Howitz.

France.

Blakey, Dax, Desloges, Kresz, O'Connor, Tolfrey.

(Fish culture.)

Coste.

(Legislation.)

Desloges, O’Connor, René and Liersel.

Game laws. See Legislatian.

Ganges. (Fishes.)

F. Hamilton.

German Ocean.

Stacy-Watson.

Germany.

Book of sports, Borne, Horrocks.

Gloucester, Mass. (Fïsheries.)

Procter.

Gold Coast. (Fisheries.)

Moloney.

Goldfish.

Mulertt.

Grayling.

Chitty, Dick, F. Francis, Halford, Halieutics, E. Hamilton, Horrocks, Jackson, A. M. Mayer, Northrup, Pennell, Pritt, Roberts, Ronalds, Shipley, Theakston, Walton and Cotton, Wheatley.

Great Brituin.

Hofland, Pennell, Senior, Taylor, Theakston, Wheeldon.

See also names of English counties and rivers, England, North of, and Lake Country', Eng.

* * Many of the general treatises on angling, which are not indexed, are descriptive of English methods.

(Fish culture.)

Bertram.

See also the general treatises under Fish cuiture.

(Fisheries.)

Alfred Ernest Albert, Bertram, Blake, Chater, Day, Dempster, R. Fraser, Holdsworth, Jenner (I65I), Paterson, Shaw-Lefevre, Stacy-Watson, Walpole, Walsh, Wilcocks.

See also Great BRITAIN in the List. -(Fishes.)

Bertram, Bewick, Buckland, Couch, Day, R. Hanilton, Houghton, Keene, Kent, Pennell, Yarrell.

(Legislation.)

Chetham (I 700), N. $\operatorname{Cox}(1786$, etc.), 
Needham, Neil, Paterson, Pollock, Whole art of fishing (I7I4, etc.). Greenland. (Fishes.)
A. Fraser.

Grig-zueels. Grilse.

H. R. Robertson.

Halieutics, Mackenzie.

Ground angling. See Bottom fishing.

Harbors.

WV. A. Smith, Wilcocks, Archibald Young.

Harpoon.

Two essays.

Iawaii. (Fishes.)

Streets.

Hebrides.

Sixty-one.

Heraldry, Fïshes in.

Moule, Robinson.

Herring fishery.

J. Campbell, Davies, Duff, Fraser, H. J. Green, Halieutics, D. Herbert, Hogarth, Miln, J. M. Mitchell, Munro, Stacy-IVatson.

Highlands, Scotland.

Abbott, Colquhoun, Conway, Dykes, Halieutics, D. Herbert, Hicks, E. L. Peel, C. St. John, W. A. Smith, Thornton.

Holland. See Netherlands.

Hooks. See Fish-hooks.

Horse and Groom fishery.

Angler's companion.

Houghton Fishing Club.

Penn.

Humor.

Anglican friar, W. L. Brown, Burnand, Collection of scarce, curious, and valuable pieces, Crawhall, Finlay, Hood, Leech, James Martin, A. M. Mayer, Penn.

Hybridization.

R. B. Roosevelt.

Ice, Preservation of.

D. Herbert.

Ichthyology. See Fish.

Ichthyophagous Club.

New York (City).

Illinois. (Fish culture and Fisheries.)

See ILliNOIS in the List.

(Fishes.)

Forbes.

India.

Pollok, Thomas.

- (Fisheries.)

Day.

(Fishes.)

Beavan, Day, Hamilton.

Insuranic for fishermen.

De Caux.

Intelligence of fish.

Romanes.

Ireland.

Barry, Belton, Blakey, Coad, Hi-Regan, O'Gorman, Peard.

(Fisheries.)

Bloomfield, Brabazon, Great Britain Inspectors of Irish fisheries, Holds. worth, Longfield, Walsh.
Ireland (continued).

- (Fishes.)

Houghton, Patterson.

(Legislation.)

Longfield.

Italy. (Fisheries.)

Ninni.

Fack.

Halieutics, Pennell, T. F. Salter.

See also Pike.

Facques Cartier River, Canada.

Lanman.

Famaica. (Fïshes.)

Gosse.

Fapan. (Fisheries.)

Okoshi.

(Fishes.)

Brevoort.

Felly-fishes.
A. Wilson.

Kent, Eng.

Halieutics, Kentish angler.

Kerguelen Island. (Fishes.)

Kidder.

Killing fish. See Cruelty, Prevention of.

Kraken.

Lee.

Labrador.

\section{Gillmore.}

(Fishes.)

H. R. Storer.

Lake Country, Eng.

Blakey, J. Davy.

Lake Superior.

Lanman, R. B. Roosevelt, Whitcher. (Fishes.)

Ágassiz.

Lancashire, Eng.

Lapland.

J. E. Taylor.

Wheelwright

Lazes. See Legislation.

Lea River, Eng.

Angler's companion, Halieutics, T. F. Salter, Thorne, Wheeldon.

Legends.

Newland, Robinson.

Legislation.

Chater, Fryer, García Solá, Morris, Pollock, Shaw-Lefevre.

See also Legislation under Canada, France, Great Britain, Ireland, Maine, New Hampshire, United States.

Lews, Island of.

Halieutics, Sixty-one.

Life-saving.

Roper.

Lincolnshire, Eng.

Halieutics.

Line fishing. See Sea fishing.

Lines. See Tackle.

Ling.

A. Fraser.

Lobsters.

Blakey, Kent, IV. B. Lord.

Loch Creran, Scotland.

W. A. Smith.

Loch Leven, Scotland.

Lochleven angler. 
London.

Angler, Baddeley, Highley, James Martin, T. F. Salter, Wheeldon.

See also Thames River, Lea River.

London, Fish-market for.

Cayley and Bridgman.

Lower California. (Fishes.)

Streets.

Lugg River, Eng. and Wales.

Marston.

Lycoming Creek, Pa.

Up de Graff.

Mackerel fishery.

T. Cornish, Goode and others, Halieutics, S. Howitt.

Madeira. (Fishes.)

Lowe.

Madras.

Pollok.

Mahseer.

Maine.

Thomas.

Allerton, Farrar, Gillmore, Hubbard, Steele, Stephens, Stevens.

(Fish iulture and Fisheries.)

See Marne in the List.

(Legislation.)

Farrar.

Malabar. (Fishes.)

Day.

Wammoth Caye, $K_{y}$. (Fishes.)

Putnam.

Man, Isle of.

Tod.

Markets. See Fish-markets.

Maryland.

Philadelphia, Wilmington \& Baltimore R. R.

(Fish culture and Fïsheries.)

See MARYland in the List.

(Fishes.)

Uhler and Lugger.

Massachusetts. (Fish culture and Fisheries.) See Massachusetrs in the List.

(Fishes.)

Goode and Bean, J. V. C. Smith, D. H. Storer.

Match fishing.

Lowth.

Menhaden.

Goode.

Mermaids.

Lee.

Mexico, Gulf of.

Harmsworth.

Michigan.

Halieutics, J. L. King, A. M. Mayer, Northrup.

(Fish culture and Fisheries.)

See Michigan in the List.

.Minnesotn. (Fish culture and Fïsheries.)

See Minnesota in the List.

Minnow fishing.

Wade.

Moisic River, Canada.

Halieutics.

Mole River, Eng.

Thorne.

Molluses.

Carr, Harding, Massachusetts - Zoölogiial and totanical survey, Wilcocks.
Moosehead Lake.

Farrar, Hubbard.

Morocco.

Payton.

Moselle River.

Music.

Waring.

H. Phillips.

See also Songs.

Muskallonge.

Gillmore.

Mussels.

Carr, Harding, Wilcocks.

Nautilus.

Lee.

Netherlands.

Harting.

(Fisheries.)

Beaujon, J. Campbell [r750], Jenner (I65I), Keymor (I664).

N'ets.

Bathurst, D. Herbert, Holdsworth, Neckam, H. R. Robinson.

New Brunswick.

R. B. Roosevelt.

(Fisheries.)

Perley.

(Fishes.)

A. L. Adams.

New England.

Carter, Prime.

Newfoundland. (Fisheries.)

Halieutics, W. R. Kennedy, Shea.

Nezu Hampshire.

Farrar, Prime.

- - (Fish culture and Fisheries.)

See New Hampshire in the List.

(Legislation.)

Farrar.

New Fersey. (Fish culture and Fisheries.'

See NEw Jersey in the List.

Neru South Wales.

J. H. Clark, S. Howitt. (Fishes.)

Ramsay.

New York.

Wallace.

(Fïsh culture and Fisheries.)

See NEw YORK in the List.

(Fïhes.)

De Kay.

New Zealand.

Nile.

Senior.

Baker.

Nipigon River, Ont. J. L. King, Whitcher.

Nipissiguit River, $N . B$.

Halieutics.

Norfolk, Eng.

Davies, Halieutics, J. E. Taylor.

Normandy.

Roscoe, Tolfrey.

North Sea. See German Ocean.

Northumberland, Eing.

Chatto, Halieutics.

Norway.

Barnard, Belton, Bowden, Forester, Halieutics, Kennard, Laing, Lloyd, Milford, Newland, Three in Norway, Tolfrey. 
Nomway (continued).

-(Fisheries.)

Bowden, D. Herbert, Wallem.

(Fishes.)

Lloyd.

Nottingham, Eng.

Bailey, J. W. Martin.

Nova Scotia.

Hardy, Lanman.

(Fisheries.)

Perley.

(Fïhes.)

H. R. Storer.

Novarro River, Col.

Halieutics.

Novels. See Fiction.

Ocean.

Watt.

See also Sea fish and fishing.

Ohio. (Fish culture and Fisherics.)

See OHIo in the List.

Orkney Islands. (Fisheries.)

Fea.

Oszostry, Eng.

Cathrall.

Oyster culture.

Anson and Willett, Dempster, Halieutics, Harding, D. Herbert, Hoek, Hubrecht, Peard, Ramsay, IV. A. Smith.

Pacific Ocean.

Gill, Girard, Lockington.

See also Sea fishing.

Pain in fishes.

Bentley.

Pan-fish.

Halieutics.

Parasites of fishes.

Cobbold.

Passaic River, N. $\mathcal{F}$.

H. W. Herbert.

Pearl fishery.

Halieutics.

Pennsylvania. (Fish culture and Fïsheries.) See Pennsylvania in the List. (Fïhes.)

Perch. Cope.

Lady Campbell, Jardine.

Periodicals.

American angler, American naturalist, Angler's note-book, Fisherman's magazine and review, Fishing gazette, Little (Anglers' annual).

Pru. (Fishes.)

Günther.

Philadelphia, Pa.

Picardy.

Schuylkill fishing company.

Pike.

Tolfrey.

Alfred, Angler's pocket-book, Blakey, Book of sports, Davies, F. Francis, J. IV. Martin, Nobbes, Old Calabar, Pennell, Roberts, Roscoe, T. F. Salter, J. E. Taylor.

Pilchard fishing.

T. Cornish, D. Herbert.

Plagiostomi.

Müller and Henle.
Poaching.

Jefferies, G. E. Jones.

Poetry.

Anglican friar, Art of angling (1773, etc.), Boaz, Browne (1729, etc.), Charleton, Collection, Crawhall, Dennys $\left[161_{3}\right.$, etc. $]$, Fisher's garland, Fletcher (1633, etc.), S. Ford (1699, etc.), Fournival, Gay, Innocent epicure (I697), Ireland, Isys, Lathy, Liddell, Lowell, McLellan, A. M. Mayer, Oppianus (1597, etc.), Saluste (1608, etc.), Sannazaro (1648), Stoddart, Vanière, Wayth, Westwood, Whitney [1700].

See also Songs.

Porpoise.

A. M. Mayer.

Potomac River.

Halieutics, Lanman.

Prazens.

W. B. Lord.

Prehistoric fishing.

Rau.

Preserving fish. See Curing fish, Cold Prussia. storage.

Roberts.

(Fïh culture, Fisheries, and Fishes.)

Benecke.

Quebec, Province of.

Dawson.

Rangeley Lakes.

Farrar, Halieutics, A. M. Mayer.

Raritan River, N. 7 .

H. W. Herbert.

Rays.

Reel.

A. Wilson.

A. M. Mayer.

Restigouche River, $N . B$.

Lanman.

Rhenish Provinces.

Roberts.

Rhode Island. (Fish culture and Fisheries.)

See RHOde IsLand in the List.

Ripon, Eng.

Theakston.

Rivers.

James.

Rivers, Pollution of.

Kennett-Barrington, Massey-Mainwar-

Roach. ing.

Fennell, F. Francis.

Rock fishing.

Rods.

Gentleman angler.

Cheek, Chubb, Gillmore, A. M. Mayer, IVebster.

See also Tackle.

Rozisley, Eng.

Russia.

Briggs.

S. Howitt, Whishaw.

Saguenay River, Canada.

Lanman.

St. Lazurence River.

Nettle. 
Salmon. (Angling.)

Adamson, Bowden, Braithwaite, Bromley-Davenport, Cartwright, Chitty, Colquhoun, Conway, Sir H. Davy, Dawson, Dougall, Dykes, Fitzgibbon, F. Francis, Franck (I694), Gillmore, Grant, Halieutics, E. Hamilton, Hansard, G. E. Jones, A. E. Knox, J. K. Lord, A. M. Mayer, Milford, Peard, Pennell, Rooper, R. B. Roosevelt, Scrope, Speedy, Stoddart, Tolfrey, Wells, John Wilson, Younger.

Salmon culture.

Ashworth, Ayrton, Barnard, W. Brown, Buckland, Esdaile, Fry, Garnett, Jacobi, Norris, Sir S. Wilson, Andrew Young.

See also Salmonidae.

Salmon disease. See Disease.

Salmon. (Embryology.)

Vogt.

Salmon fisheries.

J. Cornish, Fryer, Great Britain, D. Herbert, Leith, Mackenzie, MilneHome, Nettle, Paterson, Russel, Willis-Bund, Andrew Young, Archibald Young.

Salmon. (Ichthyology.)

Braithwaite, J. Cornish, Fitzgibbon, A. Fraser, Garman, Jordan, Russel, Scrope, Willis-Bund, Yarrell, Andrew Young.

Salmonidae.

Andrews, Braithwaite, Chambers, Day, Gillmore, Girard, Hogg, Maitland, IV. A. Smith, Stirling.

San Francisio. (Fïshes.)

Scotland.

Girard, Lockington.

Black Palmer, Blakey, Border angler, Chatto, Colquhoun, Dryden, Dykes, F. Francis, Franck (1649, etc.), Hicks, Idle, R. Knox, Locke, J. Robertson, Speedy, Stoddart, Andrew Young.

(Fisheries.)

Bell, J. Campbell, Duff, Great Britain, Halieutics, D. Herbert, Leith, Mackenzie, Miln, Milne-Home, Ross, P. White, Archibald Young.

See also Salmon fisheries.

(Fishes.)

Parnell.

Sea fables.

Lee, Robinson.

Sea fish and fishing.

Bickerdyke, Blake, Borne, Carter, Clements, Colquhoun, Davies, Gentleman angler, Holdsworth, Hudson, IV. Jones, Lanman, Lennox, Lister, W. B. Lord, Meunier, Mundahl, Rondelet, Senior, Wilcocks, L. J. H. Young.

See also Fisheries, Ocean.

Sea monsters.

Seal.

$$
\text { Lee. }
$$

H. W. Elliott, Temple.

Sea-serpent.

Buckland, W. Elliott, Lee.

Sea-trout.

Halieutics, A. M. Mayer, R. B. Roosevelt, Roscoe.
Serpentine (The), London.

Buckland.

Severn Valley, Eng.

Shad.

Randall.

Norris.

See also Fïsh culture.

Shakespeare as an angler.

Ellacombe.

Shark.

S. Howitt, Two essays.

Sheeps-head fishing.

IV. Elliott.

Shell-fish.

Rumph (I 7 I I).

Shetland Islands. (Fisheries.)

Shrimp.

J. Campbell, Fea, Miln.

Skates.

W. B. Lord.

Smelt.

A. Wilson.

Cole, H. WV. Herbert, Theakston.

Societies. (Angling.)

Bradfield, Edinburgh, London, Low, Manchester, New York, Schuylkill, Skinner, Wheeldon.

(Fish culture, etc.)

American fish culturists' association, American fisheries society, Central fishcultural society, Fryer.

Sole.

Houghton.

Songs.

Angler's garland, Armiger, Baddeley, Blakey, Collection of right merrie garlands, Dexter, Doubleday, Dykes, Edinburgh angling club, Fisher's garland, W. A. Foster, H. Phillips, Scrapbook, Stoddart.

See also Music, Poetry.

South Carolina.

W. Elliott.

(Fishes.)

Holbrook.

Soval fishing.

Sixty-one.

Spain. (Fisheries.)

García Solá.

Spey River, Scotland.

A. E. Knox.

Spinning.

Alfred, Burgess, J. W. Martin, Pennell.

See also Tackle.

Sponges.

Kent.

Starfishes.

Agassiz.

Suez Canal.

Senior.

Suffolk, Eng.

Halieutics.

Sussex, Eng.

Thorne.

Sutherland, Scotland.

Halieutics, Archibald Young.

Stueden.

Lloyd, Newland, Wheelwright.

(Fisheries.)

D. Herbert, Smitt.

(Fishes.)

Lloyd, Wheelwright. 
Switzerland.

Borne, Matthey.

Swordfish.

Lanman.

Tackle.

Alfred, Cheek, Chubb, A. Gould, Hardy, Henshall, Hi-Regan, Holdsworth, Keene, Giles Little \& Co., J. K. Lord, A. M. Mayer, Pennell, Tolfrey, Webster, Wells, Wilcocks, Young anglers' companion.

See also Fïh-hooks, Nets, Reel, Rod. Tarpon.

Harmsworth.

Tasmania.

Senior.

(Fishes.)

Günther.

Tay River, Scotland.

Halientics.

Teesdale, Scotland.

Lakeland.

Teme River, Wales.

Marston.

Tenby, Wales.

Lister.

Texas. (Fishes.)

Cope.

Thames River, Eng.

Essay on the right of angling, etc., Gentleman angler, Griffiths, Hassell, H. R. Robertson, Rooper, T. F. Salter, A. W. Smith, A. W. Smith and Hallett, Thorne, Wheeldon.

Transportation.

Walpole.

Trawling.

Ansell, D. Herbert.

Trent River, Eng.

J. W. Martin, Snart.

Trimmer angling.

Cole, T. F. Salter.

Trolling.

Alfred, Angler's companion, Angler's pocket-book, Burgess, Carpenter, Cole, Fitzgibbon, Nobbes, Pennell, T. F. Salter, Shipley.

Trout. (Angling.)

Allerton, Barry, Burroughs, Chitty, Cutcliffe, Dawson, Dick, Dougall, Dryden, T. Ford, F. Francis, Gillmore, Grey Drake, Halford, Halieutics, E. Hamilton, Hansard, D. Herbert, H. W. Herbert, Horrocks, How to catch trout, Hughes, Lakeland, Lanman, Lorgh, Matthey, A. M. Mayer, Nettle, Orvis and Cheney, Pennell, Prime, Pritt, Pulman, Roberts, J. Robertson, Ronalds, R. B. Roosevelt, Senior, Shipley, J. V. C. Smith, Soltau, Speedy, Stewart, Stoddart, Theakston, Three in Norway, Tod, Walton and Cotton, Wayth, IVheatley, Whitcher, Younger.

Trout culture.

Buckland, Capel, S. Green, Jacobi, Norris, Slack, Stone, Sir S. Wilson.

Trout. (Ichthyology.)

Garman, A. M. Mayer.

Turtles.

Agassiz, S. Howitt.
Taveed River, Scotland.

Border angler, Locke, Rooper, Scrope, Tyrol. Younger.

Roscoe.

Umber. See Grayling.

United Stutes.

American angler, American fish, J. J. Brown, Harris, H. W. Herbert, Lanman, Norris, Schreiner, G. C. Scott, Shields, Wells.

See also America, North.

(Fish culture.)

Berlin, Garlick, Goode, Norris.

(Fisheries.)

Berlin, Goode, Philadelphia, Sabine, Smiley.

(Fishes.)

Gill, Goode, Lockington.

See also United States in the List.

(Legislation.)

M. B. Brown \& Co.

Vallorbe, Szuitzerland.

Matthey.

Vancouver Island.

J. K. Lord.

Venice. (Fïsheries.)

Ninni.

Vermont. (Fïsh culture and Fisheries.)

See VERMONT in the List.

Vineyard Sound. (Invertehrates.)

Verrill.

Virginia.

Halieutics, P. Kennedy.

(Fish culture and Fisheries.)

See VIRGINia in the List.

Wales.

Ayrton, Blakey, Cliffe, Hansard, G. E. Jones, Lister, Medwin.

(Fisheries.)

Great Britain.

Walton, Izaak.

Burnand, Cargill, D. G. Mitchell, Satchell, Simms, VVestwood, Zouch.

IV ashington, George, as an angler.

Moore.

West Indies.

IV. R. Kennedy.

Westmorland, Eng.

Chatto, J. Davy.

Wey River, Eng.

Thorne.

Uhales.

Aldrovandi (1613), Bickerdyke, Gore. Booth, Halieutics, D. Herbert, S.

Howitt, Lee, Starbuck, Two essays, J. Wilson.

Whelks.

See also Cetacea.

Harding.

White-fish.

J. K. Lord.

White Ilouse fishery.

Angler's companion.

Winchester, Eng.

F. Francis, $j$. 
IVisconsin.

J. L. King.

(Fish culture and Fisheries.)

See Wisconsiv in the List.

Worm fishing.

Halieutics, Pennell, Wade.

Wye River, Eng.

Briggs.

Yarmouth, Eng. (Fisheries.)

Stacy-Watson.

Yorkshire, Eng.

Pritt.

Zanzibar. (Fishes.)

Playfair and Günther.

Zetland. See Shetland Islands.

23

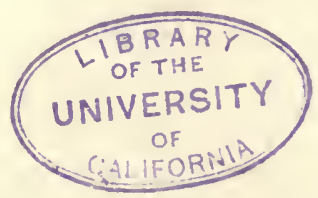






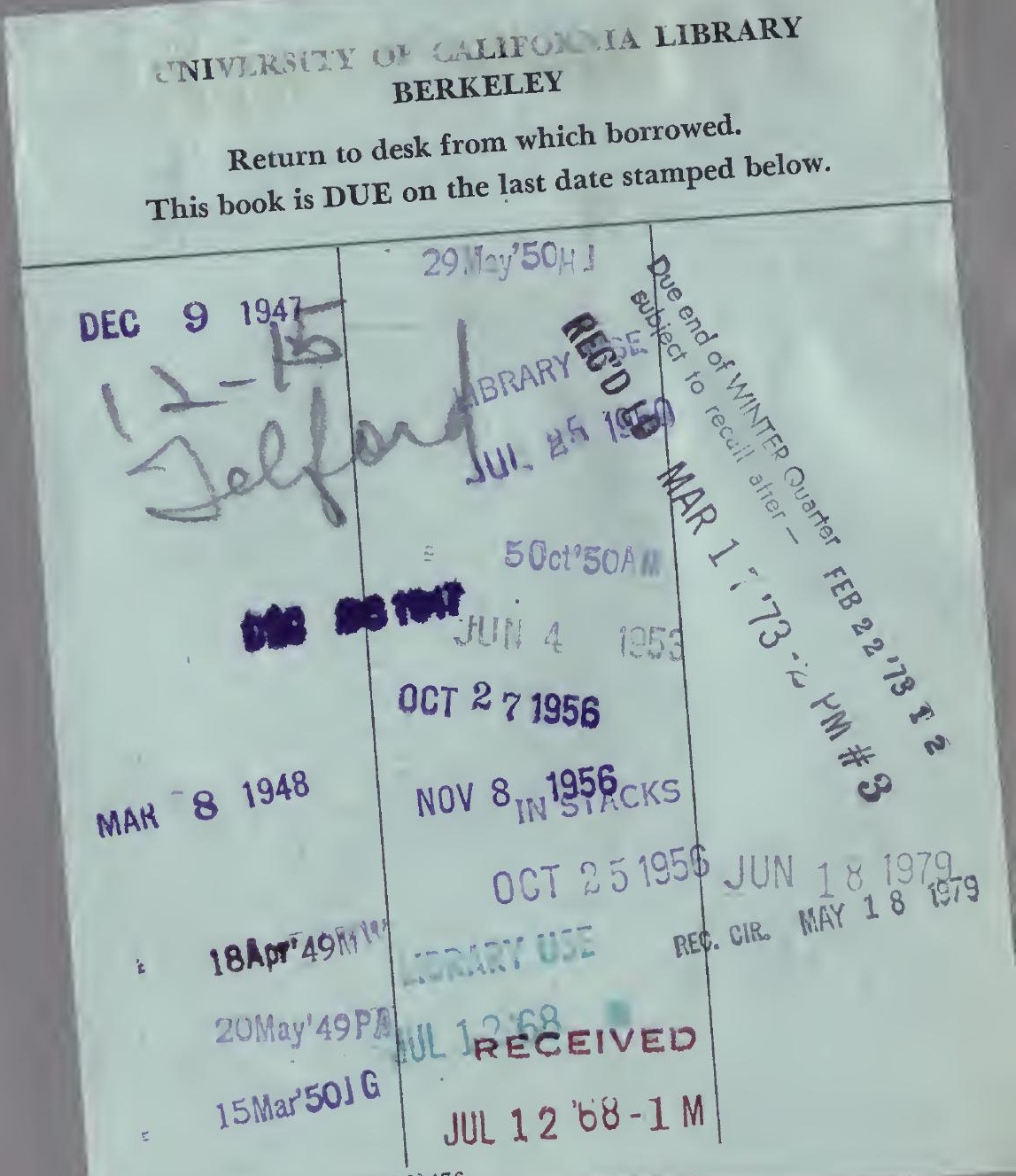

21-100m-9,'47(A5702s16)476

LOAN DEPT 
